\title{
APLICACIONES DEL FACTOR DE TRANSCRIPCIÓN ROSEA1 DE LA RUTA DE LAS ANTOCIANINAS COMO MARCADOR VISUAL EN VIROLOGIA MOLECULAR Y BIOTECNOLOGIA DE PLANTAS
}

\author{
María Teresa Cordero Cucar† \\ Director: Dr. José Antonio Daròs Arnau \\ Valencia, Mayo 2021 \\ UNIVERSITAT
POLITÉCNICA
DE VALENNCIA
}




\section{APLICACIONES DEL FACTOR DE TRANSCRIPCIÓN ROSEA1 DE LA RUTA DE LAS ANTOCIANINAS COMO MARCADOR VISUAL EN VIROLOGÍA MOLECULAR Y BIOTECNOLOGÍA DE PLANTAS}

María Teresa Cordero Cucart

Mayo 2021

DIRECTOR:

Prof. José Antonio Daròs Arnau 

El Dr. José Antonio Daròs Arnau, Profesor de Investigación del Consejo Superior de Investigaciones Científicas (CSIC), en el Instituto de Biología Molecular y Celular de Plantas (IBMCP), centro mixto del CSIC y de la Universitat Politècnica de València

\section{CERTIFICA:}

Que la Licenciada en Químicas MARÍA TERESA CORDERO CUCART ha realizado bajo su dirección en el IBMCP el trabajo que lleva por título "Aplicaciones del factor de transcripción Roseal de la ruta de las antocianinas como marcador visual en virología molecular y biotecnología de plantas", y autoriza su presentación para optar al grado de Doctor.

Y para que conste, expide y firma el presente certificado en Valencia, 20 de Abril de 2021. 

A Leo 



\section{Contenido}

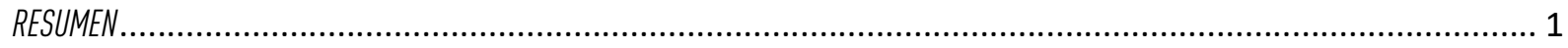

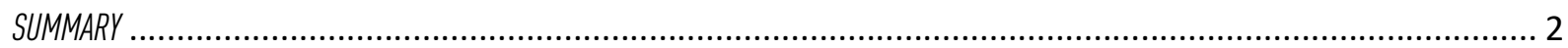

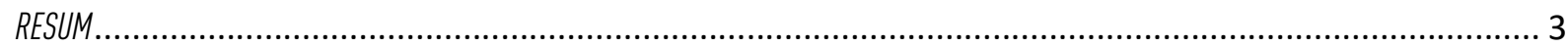

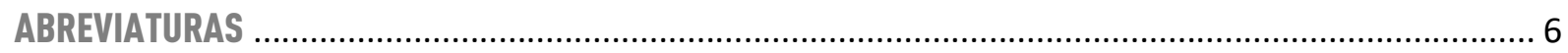

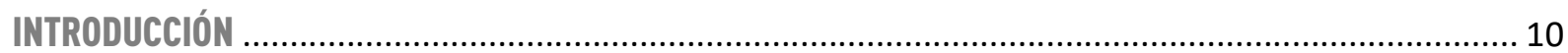

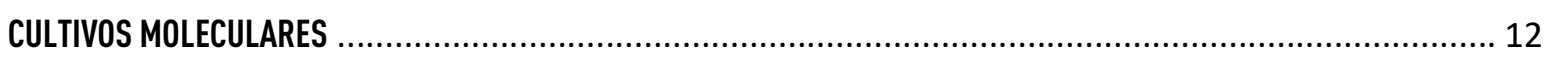

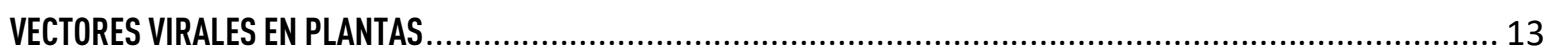

USO DE GENES REPORTEROS PARA EL SEGUIMIENTO DE LAS INFECCIONES VIRALES EN PLANTAS ........................... 18

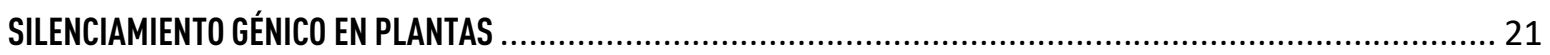

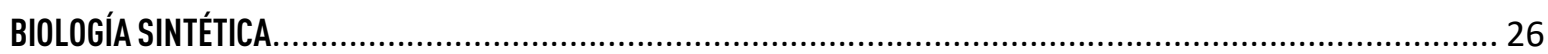

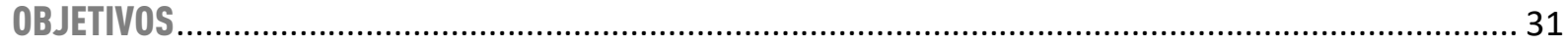

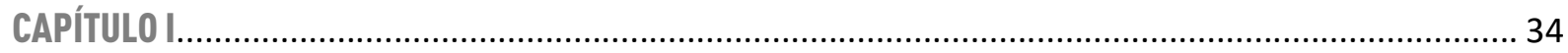

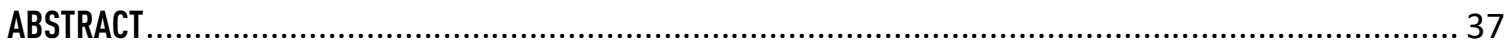

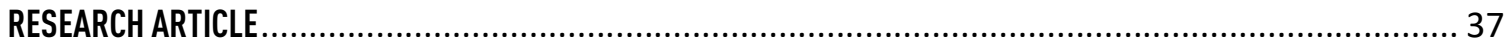

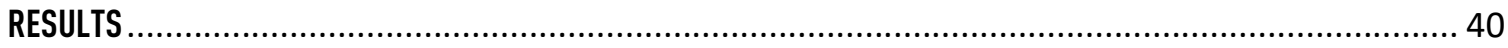

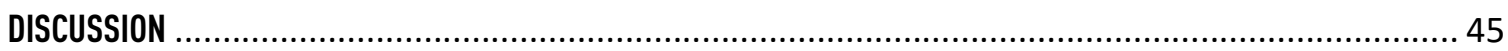

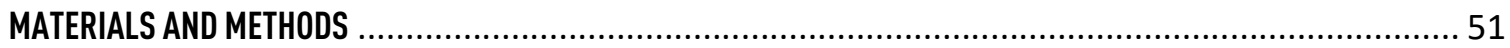

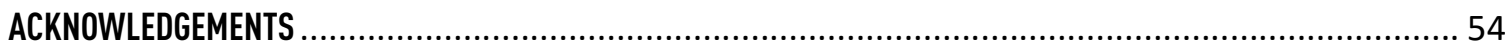

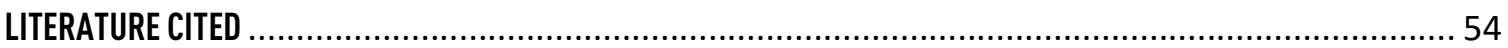

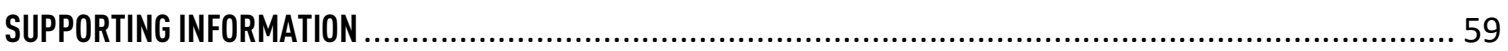

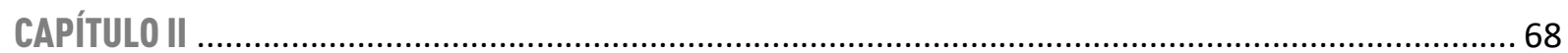

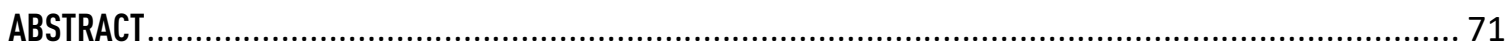

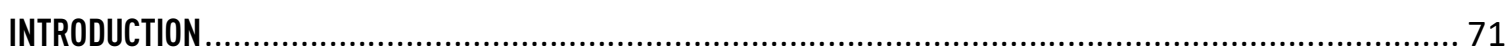

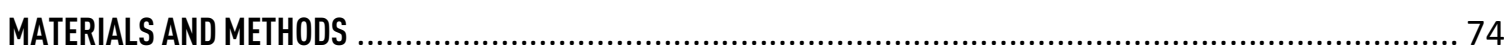

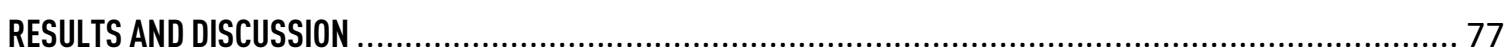

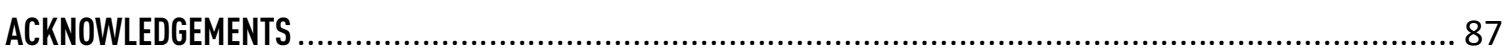

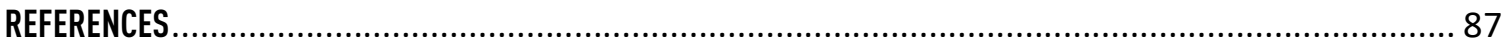

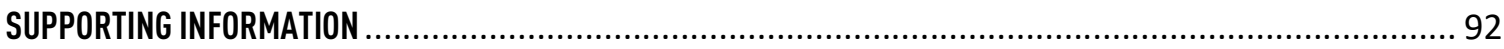

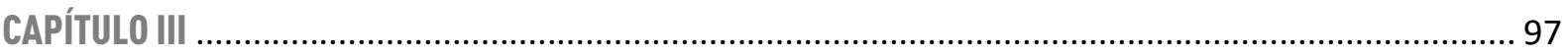

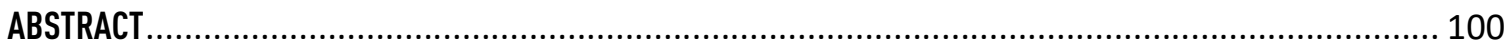

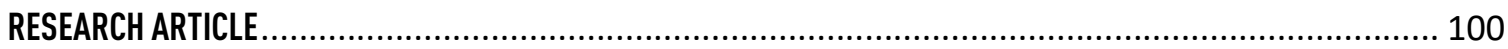

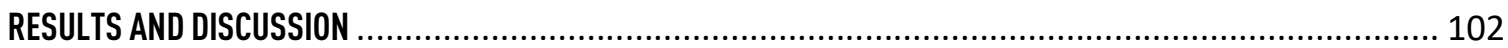

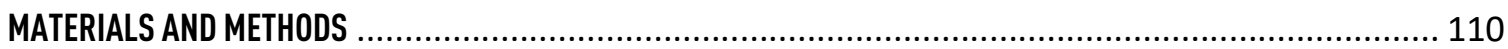

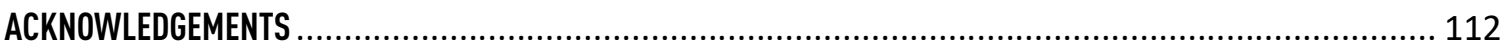


REFERENCES.

113

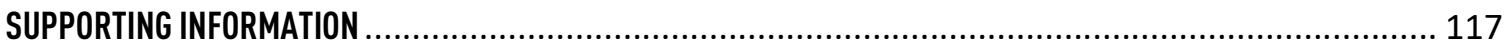

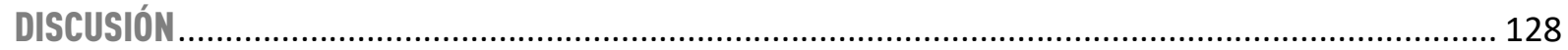

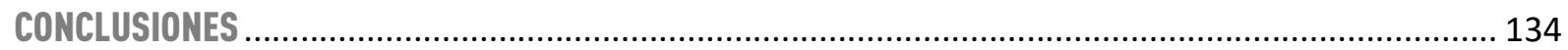

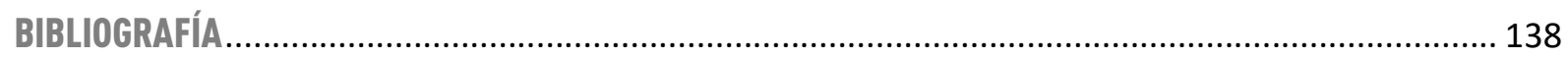

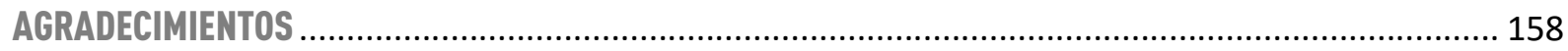

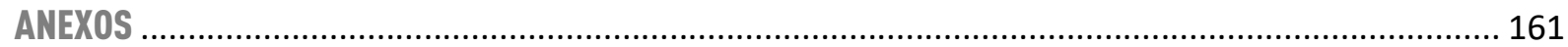





\section{RESUMEN}

Los virus de plantas poseen la capacidad de parasitar células vegetales y poner a su disposición la maquinaria celular de la planta para la síntesis de sus propias proteínas. Aprovechando esta capacidad, la ingeniería genética ha dirigido muchos de sus esfuerzos en la modificación del genoma viral para utilizar los virus de plantas como vectores de expresión de proteínas de interés humano. Estas proteínas se almacenan en las plantas huésped que actúan como biofactorías de bajo coste y con elevada seguridad. Los potyvirus son un grupo de virus de plantas ampliamente estudiado y utilizado en biotecnología. Su genoma está formado por un RNA de cadena sencilla que codifica, principalmente, una poliproteína que se procesa para dar aproximadamente 10 proteínas maduras. En diferentes posiciones intercistrónicas de los potyvirus se pueden insertar cDNAs que codifican proteínas de interés, las cuales se producen junto al resto de productos de la poliproteína. Si además estos cDNAs se flanquean por secuencias que codifican los sitios de procesamiento específicos de las proteasas virales, las proteínas heterólogas se liberan eficientemente de la poliproteína viral. Así, la inserción de un cDNA correspondiente al factor de transcripción Roseal de la ruta de las antocianinas en distintos potyvirus resulta en la biosíntesis de estos compuestos en las células vegetales infectadas. Las antocianinas son compuestos flavonoides coloreados que se pueden observar a simple vista, por lo que la expresión de Roseal en el contexto de la infección viral es una herramienta biotecnológica muy útil para seguir la infección de virus de plantas. En esta Tesis se han investigado diferentes aplicaciones biotecnológicas basadas en la expresión del factor de transcripción Rosea1 y la consecuente acumulación de antocianinas en el contexto de la biología de los potyvirus. Primero, se construyó un clon del virus del mosaico amarillo del calabacín (ZYMV, género Potyvirus) etiquetado con Rosea1 (ZYMV-Ros1). El ZYMV es capaz de replicarse a nivel local pero no de moverse a larga distancia en plantas de Nicotiana benthamiana. Un análisis de la infección por ZYMV-Ros1 en una serie de plantas transgénicas de $N$. benthamiana silenciadas en distintas RNasas de tipo Dicer (DCL) permitió profundizar en el conocimiento de los mecanismos defensivos de la planta frente a este virus. Los resultados indicaron que DCL4 está implicada en restringir el movimiento sistémico del virus, ya que en plantas con este gen silenciado el virus es capaz de moverse a larga distancia. Además de su potencial biotecnológico como marcadores de actividades biológicas, las antocianinas son objeto de un gran interés nutricional, y también farmacéutico e incluso industrial, por su gran actividad antioxidante. Un clon viral derivado del virus Y de la patata (PVY; género Potyvirus) que expresaba Rosea1 (PVY-Ros1) indujo la acumulación de más antocianinas que las que contienen frutas y verduras que son fuente rica de estos valiosos antioxidantes. Este mismo clon 
PVY-Ros1 también se utilizó para estudiar la transmisión del virus mediante áfidos vectores, observándose como estos provocan frecuentemente el inicio de la infección en el tejido vascular. Este mismo clon viral también permitió mostrar visualmente el efecto antiviral que tienen las nanopartículas de plata en plantas. Por último, en esta Tesis se combinó el factor de transcripción Rosea1 de las antocianinas con distintas proteasas de los potyvirus para crear circuitos lógicos de regulación génica en plantas. Se observó que la fusión de distintas proteínas virales, como la proteína de inclusión nuclear b (NIb) de los potyvirus o fragmentos de ella, al extremo carboxilo terminal de Rosea1 inhibía la actividad del factor de transcripción. Sin embargo, la acumulación de antocianinas se pudo restablecer insertando sitios de reconocimiento de proteasas virales entre ambas partes y coexpresando tales proteasas. $\mathrm{La}$ especificidad de corte y la eficiente actividad catalítica de las proteasas de inclusión nuclear a (NIaPro) del virus del grabado del tabaco (TEV; género Potyvirus) y del virus de las venas moteadas del tabaco (TVMV; género Potyvirus) permitió construir circuitos genéticos basados en regulación postranscripcional que son capaces de realizar algunas operaciones lógicas básicas (YES, OR y AND) en tejidos vegetales.

\section{SUMMARY}

Plant viruses have the ability to parasitize plant cells and use the plant cellular machinery for the synthesis of their own proteins. Taking advantage of this capacity, genetic engineering has focused many of its efforts in modifying the viral genome in order to use modified plant viruses as expression vectors of proteins of human interest. These proteins are stored in host plants that act as low-cost and highly secure biofactories. Potyviruses are a group of plant viruses widely studied and used in biotechnology. Their genome consist of a single-stranded RNA that mainly encodes a polyprotein that is processed in approximately 10 mature proteins. cDNAs flanked by protease specific processing sequences can be inserted in different intercistronic positions and efficiently processed by the viral proteases to produce proteins of interest together with the rest of the viral polyprotein products. Thus, the insertion of the cDNA corresponding to the transcription factor Roseal of the anthocyanin pathway in different potyviruses results in the biosynthesis of these compounds in infected plant cells. Anthocyanins are colored flavonoid compounds that can be observed with the naked eye, and thus, the expression of Roseal is a very useful biotechnological tool to follow the infection of plant viruses. In this work, we provided different biotechnological applications based on the expression of this transcription factor and the consequent accumulation of anthocyanins in the context of potyvirus biology. First, a zucchini yellow mosaic virus (ZYMV, genus Potyvirus) clone tagged with Rosea1 
(ZYMV-Ros1) was constructed. ZYMV is able to replicate locally but not to move long distances in Nicotiana benthamiana plants. We analyzed the infection by ZYMV-Ros1 in a series of $N$. benthamiana transgenic plants in which the different Dicer-like (DCL) RNases were slilenced. The results showed that DCL4 is involved in restricting the systemic movement of the virus in $N$. benthamiana plants. This study allowed to deepen the knowledge of the defense mechanisms of the plant against this virus. Besides their biotechnological potential as markers of biological activities, anthocyanins have great nutritional, pharmaceutical and even industrial interest due to their high antioxidant activity. We found that a potato virus $\mathrm{Y}$ clone (PVY; genus Potyvirus) expressing Rosea1 (PVY-Ros1) induced the accumulation of a higher amount of anthocyanins than those contained in fruits and vegetables that are a rich source of these valuable antioxidants. The PVY-Ros1 clone was also used to study the transmission of the virus by aphid vectors. We observed that aphids frequently initiate infection in vascular tissue. This viral clone also allowed to visually show the antiviral effect of silver nanoparticles in plants. Finally, in this work, the Roseal transcription factor was combined with different potyvirus proteases to create genetic circuits in plants. We observed that the fusion of the nuclear inclusion protein $\mathrm{b}(\mathrm{NIb})$ of potyviruses, or fragments of it, to the carboxyl terminal end of Rosea1 inhibited the activity of the transcription factor. However, the accumulation of anthocyanins could be restored by inserting viral protease recognition sites in between NIb and Rosea 1 and co-expressing those proteases. The cleavage specificity and the efficient catalytic activity of nuclear inclusion a proteases (NIaPro) of tobacco etch virus (TEV; genus Potyvirus) and tobacco spotted vein virus (TVMV; genus Potyvirus) allowed the construction of genetic circuits based on post-transcriptional regulation that are capable of performing some basic logical operations (YES, OR and AND) in plant tissues.

\section{RESUM}

Els virus de plantes posseeixen la capacitat de parasitar cèl·lules vegetals i posar a la seva disposició la maquinària cel·lular de la planta per a la síntesi de les seves pròpies proteïnes. Aprofitant aquesta capacitat, l'enginyeria genètica ha dirigit molts dels seus esforços a la modificació del genoma viral per utilitzar els virus de plantes com a vectors d'expressió de proteïnes d'interès humà. Aquestes proteïnes s'emmagatzemen en les plantes hoste que actuen com a biofactories de baix cost i elevada seguretat. Els potyvirus són un grup de virus de plantes àmpliament estudiat $\mathrm{i}$ utilitzat en biotecnologia. El seu genoma està format per un RNA de cadena senzilla que codifica, principalment, una poliproteïna que es processa per donar aproximadament 10 proteïnes madures. En diferents posicions intercistróniques dels potyvirus 
es poden inserir cDNAs que codifiquen proteïnes d'interès, les quals es produeixen alhora amb la resta de productes de la poliproteïna. Si a més aquests cDNAs es flanquegen per seqüències que codifiquen els llocs de processament específics de les proteases virals, les proteïnes heteròlogues s'alliberen eficientment de la poliproteïna viral. Així, la inserció d'un cDNA corresponent al factor de transcripció Roseal de la ruta de les antocianines en diferents potyvirus resulta en la biosíntesi d'aquests compostos en les cèl·lules vegetals infectades. Les antocianines són compostos flavonoides colorits que es poden observar a simple vista, de manera que l'expressió de Roseal en el context de la infecció viral és una eina biotecnològica molt útil per seguir la infecció de virus de plantes. En aquesta Tesi s'han investigat diferents aplicacions biotecnològiques basades en l'expressió del factor de transcripció Rosea1 i la conseqüent acumulació d'antocianines en el context de la biologia dels potyvirus. Primer, es va construir un clon del virus del mosaic groc del carbassó (ZYMV, gènere Potyvirus) etiquetat amb Rosea1 (ZYMV-Ros1). El ZYMV és capaç de replicar-se a nivell local però no de moure's a llarga distància en plantes de Nicotiana benthamiana. Un anàlisi de la infecció per ZYMVRos1 en una sèrie de plantes transgèniques de $N$. benthamiana silenciades en diferents RNases de tipus Dicer (DCL) va permetre aprofundir en el coneixement dels mecanismes defensius de la planta front aquest virus. Els resultats van indicar que DCL4 està implicada en restringir el moviment sistèmic del virus, ja que en plantes amb aquest gen silenciat el virus és capaç de moure's a llarga distància. A més del seu potencial biotecnològic com marcadors d'activitats biològiques, les antocianines són objecte d'un gran interès nutricional, farmacèutic $i$ fins $i$ tot industrial, per la seva gran activitat antioxidant. Un clon viral derivat del virus $\mathrm{Y}$ de la patata (PVY; gènere Potyvirus) que expressava Rosea1 (PVY-Ros1) va induir l'acumulació de més antocianines que les que contenen fruites i verdures que són font rica d'aquests valuosos antioxidants. Aquest mateix clon PVY-Ros1 també es va utilitzar per estudiar la transmissió del virus mitjançant àfids vectors, observant com aquests provoquen freqüentment l'inici de la infecció en el teixit vascular. Aquest mateix clon viral també va permetre mostrar visualment l'efecte antiviral que tenen les nanopartícules de plata en plantes. Finalment, en aquesta Tesi es va combinar el factor de transcripció Roseal de les antocianines amb diferents proteases dels potyvirus per crear circuits lògics de regulació gènica en plantes. Es va observar que la fusió de diferents proteïnes virals, com la proteïna d'inclusió nuclear $\mathrm{b}(\mathrm{NIb})$ dels potyvirus o fragments d'ella, a l'extrem carboxil terminal de Rosea1 inhibia l'activitat del factor de transcripció. No obstant això, l'acumulació d'antocianines es va poder restablir inserint llocs de reconeixement de les proteases virals entre les dues parts i coexpressant aquestes proteases. L'especificitat de tall i l'eficient activitat catalítica de les proteases d'inclusió nuclear a (NIaPro) del virus del 
gravat del tabac (TEV; gènere Potyvirus) i del virus de les venes clapejades del tabac (TVMV; gènere Potyvirus) va permetre construir circuits genètics basats en regulació postranscripcional que són capaços de realitzar algunes operacions lògiques bàsiques (YES, OR i AND) en teixits vegetals. 
ABREVIATURAS 

AGO, Argonauta

AMV, virus del mosaico de la alfalfa

bHLH, hélice-bucle-hélice básica

cDNA, DNA complementario

$\mathbf{C P}$, proteína de cubierta

crtB, fitoeno sintasa

DCL, Dicer-like

DNA, ácido desoxirribonucleico

dsRNA, RNA de doble cadena

GFP, proteína verde fluorescente

GUS, $\beta$-glucoronidasa

hpRNA, RNAs con plegamiento en horquilla

IPTG, isopropil- $\beta$-D-1-tiogalactopiranósido

mRNA, RNA mensajero

$\mathbf{m A b}$, anticuerpo monoclonal

MIT, instituto tecnológico de Massachusetts

miRNA, microRNA

ORF, marco abierto de lectura

PCR, reacción en cadena de la polimerasa

$\mathbf{p H}$, potencial de hidrógeno

PMMoV, virus del moteado suave del pimiento

PTGS, silenciamiento génico postranscripcional

PVX, virus X de la patata

PVY, virus Y de la patata

RITS, silenciamiento transcripcional inducido por RNA

RdDM, metilación DNA dirigido por RNA

RdRP, RNA polimerasa dependiente de RNA

RNA, ácido ribonucleico

RNAi, interferencia mediada por RNA

sRNA, pequeño RNA 
siRNAs, sRNAs de interferencia

ssRNA+, RNA de simple cadena positivo

TEV, virus del grabado del tabaco

TGS, silenciamiento génico transcripcional

TMV, virus del mosaico del tabaco

ToMV, virus del mosaico del tomate

TVCV, virus del clareamiento de las venas del nabo

UTR, región no traducida

UV, ultravioleta

VIGS, silenciamiento génico mediado por virus

HIV, virus de la inmunodeficiencia humana

VPg, proteína viral enlazada al genoma

X-gluc, 5-bromo-4-cloro-3-indolyl-beta-D-glucorónido

ZYMV, virus del mosaico amarillo del calabacín 
INTRODUCCIÓN 



\section{CULTIVOS MOLECULARES}

En las últimas décadas, la biotecnología vegetal ha logrado con éxito desarrollar cultivos con características beneficiosas y mejoradas, basándose en tres objetivos principales: (1) mejoras agronómicas como resistencia a plagas y patógenos, mejoras nutricionales, tolerancia a estreses abióticos o eficiencia en el uso de nutrientes; (2) bioenergía y (3) producción de proteínas de interés, también conocido como cultivo molecular o molecular farming (Xu et al., 2012; Chen y Lin, 2013; Schillber y Finnern, 2021). La expresión de proteínas en organismos vivos se basa en un proceso altamente conservado: el DNA se transcribe en mRNA que se traduce en polipéptidos formados a partir de aminoácidos. En la actualidad, la gran demanda de proteínas puras, correctamente plegadas y biológicamente activas ha estimulado el desarrollo de plataformas más productivas. Gracias a la investigación en biotecnología vegetal, hoy en día las plantas también se utilizan como plataformas para la producción de proteínas recombinantes (Shanmugaraj et al., 2020). El género de plantas Nicotiana es ampliamente utilizado para cultivo molecular, ya que son muy resistentes. Estas plantas pueden sintetizar productos farmaceúticos, industriales y nutrientes de gran valor a partir de rutas biosintéticas (MolinaHidalgo et al., 2020). La ventaja de las células vegetales sobre los procariotas es que poseen un sistema de endomembrana y una vía secretora que ayudan al ensamblaje y plegamiento correctos de proteínas complejas, y que llevan a cabo modificaciones postraduccionales, muy similares a las células de mamíferos (Vitale y Denecke, 1999). Además, las plataformas basadas en plantas están libres de contaminantes indeseados, como virus patógenos de animales, priones y endotoxinas bacterianas (Faye y Gomord, 2010). Los dos métodos principales de expresión de proteínas heterólogas en plantas son la transformación estable del genoma nuclear o del cloroplasto y la expresión transitoria. La principal diferencia es que, en la transformación estable, el gen exógeno se integra en el genoma y, por lo tanto, se vuelve hereditario, mientras que en sistemas transitorios la expresión de la proteína recombinante se limita a un corto período de tiempo y no afecta a todas las células vegetales, pero en aspectos como rapidez y rendimiento, los sistemas transitorios superan la transformación estable. La técnica más utilizada para la expresión transitoria de proteínas heterólogas en plantas se basa en la bacteria Agrobacterium tumefaciens. Esta bacteria del suelo tiene la capacidad de introducir genes en el cromosoma de la planta (Chilton et al., 1977). Reemplazando los genes bacterianos por genes de interés bajo el control de promotores específicos, se puede lograr la expresión de proteínas recombinantes (Herrera-Estrella et al., 1983; Zambryski et al., 1983). En el contexto de los vectores virales, otro avance técnico importante fue la técnica llamada 'agroinfección' que 
consiste en la expresión transitoria del genoma viral mediante el uso de A. tumefaciens, evitando la inoculación mecánica ineficiente de los transcritos de RNA (Grimsley et al., 1986; Pasin et al., 2019). Esta técnica da como resultado una secuencia de ácidos nucleicos que replica autónomamente después de la transcripción y procesamiento nuclear en la célula huésped, y permite que el virus se disemine por la planta generando una infección sistémica.

\section{VECTORES VIRALES EN PLANTAS}

Los virus de plantas pueden redirigir la capacidad biosintética de la célula huésped para producir nuevos virus en un corto período de tiempo mediante el secuestro de los ribosomas del huésped y forzándolos a sintetizar una gran cantidad de proteínas virales (Nelson y Citovsky, 2005). En los últimos años, se han desarrollado varios vectores de virus de plantas como vehículos para la expresión transitoria de proteínas recombinantes mediante la introducción del gen de interés en el genoma viral, o utilizando genes virales como piezas clave para desarrollar vectores de expresión, generando una forma fácil de producir grandes cantidades de proteínas utilizando las plantas como biofactorias. Los primeros vectores virales de expresión contenían el genoma viral completo y en él se insertaba la secuencia heteróloga que codifica el gen de interés (Gleba et al., 2004). Estos vectores virales se comportaban como un virus silvestre ya que mantienen todos los genes para la infección y la replicación, conservando la capacidad de movimiento sistémico y supresión del silenciamiento génico en las plantas huésped. Estos vectores tenían la limitación de que el tamaño de la secuencia del gen de interés influía negativamente en la estabilidad del vector que resultó en una menor productividad para proteínas heterólogas grandes (Avesani et al., 2007). En este punto, el objetivo principal en el diseño de vectores fue maximizar la productividad de proteínas heterólogas manteniendo solo los elementos esenciales para la expresión de proteínas y eliminando o proporcionando en trans algunos de los genes no esenciales, generando así vectores deconstruidos (Gleba et al., 2005, 2007, 2014). El sistema de expresión que utiliza un vector deconstruido más famoso basado en un virus de plantas es el magnICON, un sistema híbrido con elementos del virus del mosaico del tabaco (TMV) y del virus del clareamiento de las venas del nabo (TVCV), ambos del género Tobamovirus, familia Virgaviridae, con viriones con forma de varilla rígida y genoma de RNA monocatenario de sentido positivo (ssRNA+). El sistema magnICON está compuesto por tres módulos: el módulo 5' contiene elementos básicos de los dos tobamovirus y un promotor para la expresión del gen de interés; el módulo 3' contiene el gen de interés; y el tercer módulo que alberga una recombinasa (Marillonnet et al., 2004). El vector de expresión carece de proteína 
de cubierta (CP) y no puede moverse sistémicamente, de manera que A. tumefaciens lleva el vector viral al núcleo. Después de la agroinoculación, los módulos se fusionan mediante la recombinasa que forma el replicón de magnICON en forma de DNA que se transcribe. Con este sistema se pudieron distribuir las proteínas recombinantes a distintos compartimentos subcelulares mediante péptidos de tránsito fusionados (Gils et al., 2005), se expresaron dos proteínas en la misma célula con dos vectores virales no competitivos (Giritch et al., 2006), se consiguió la expresión de anticuerpos monoclonales (Santi et al., 2006; Webster et al., 2009; Huang et al., 2006) y se desarrolló una técnica de inoculación masiva, llamada Magnifection, que ayudó a elevar el rendimiento de la proteína recombinante hasta $5 \mathrm{~g} / \mathrm{kg}$ de peso fresco (Gleba et al., 2004; Gleba et al., 2005). Otro sistema importante de expresión génica basado en TMV es el TRBO, que es comparable a magnICON en términos de rendimientos de proteína recombinante, pero de diseño más simple (Lindbo, 2007). TRBO se construyó reemplazando la mayor parte de la región codificante de la CP de TMV por un sitio de clonación múltiple en el que se insertó el gen de interés, dando como resultado un potente vector de expresión génica capaz de producir hasta $5.5 \mathrm{~g}$ de proteína heteróloga por $\mathrm{kg}$ de peso fresco de tejido (Lindbo, 2007). Mediante este vector de expresión derivado del TMV se ha producido con éxito la expresión transitoria de mioglobina humana en plantas $N$. benthamiana (Carlsson et al., 2020). Los resultados muestran el alto potencial de las plantas para la producción de este tipo de proteínas muy valoradas en nutrición, ya que, se demostró que la proteína era funcional y que el grupo hemo se había incorporado eficientemente. En 2019 un nuevo sistema de expresión de proteínas heterólogas fue diseñado a partir del TMV. Su particularidad respecto a los ya descritos es la facilidad de clonación mediante el ensamblaje Gibson (Gibson et al., 2009) y la escasa manipulación del genoma vírico (Shi et al., 2019). El sistema se compone de dos vectores de clonación mínimos de muy fácil manejo para la inserción del gen de interés facilitada por un marcador de selección basado en el péptido alfa de la beta-galactosidasa (LacZ). Mediante una digestión de DNA o amplificación por PCR de un fragmento de estos plásmidos intermedios, se traspasa el cDNA de interés al vector final elegido. Según el plásmido intermedio elegido, se consiguen dos tipos de vectores finales, un vector de expresión local en el que la mayor parte de la CP del TMV se reemplaza por el cDNA correspondiente al marco abierto de lectura (ORF) de la proteína recombinante de interés, por tanto no podrá moverse sistémicamente en plantas infectadas, y un vector de infección sistémica, en el que se complementa la ausencia de la CP del TMV con un fragmento del genoma del virus del mosaico del tomate (ToMV) que incluye el promotor, el cDNA que codifica su CP y la 3' UTR, 
proporcionando una $\mathrm{CP}$ alternativa para encapsidar el virus recombinante que sí se mueve sistémicamente (Shivprasad et al., 1999).

Las plantas son fuente importante de muchos metabolitos secundarios valiosos y los virus de plantas tienen la capacidad de expresar enzimas biosintéticas y factores de transcripción implicados en sus rutas biosintéticas. Consecuentemente se pueden utilizar vectores virales de plantas para manipular el perfil de metabolitos secundarios de los tejidos vegetales (Sainsbury y Lomonossoff, 2014). En los últimos años se han hecho avances en el estudio de vectores virales para la producción de productos de gran valor en el campo de la medicina usando plantas como biofactorías. Se ha logrado la expresión en plantas de anticuerpos dirigidos a enfermedades de interés, como el HIV (Ma et al., 2015) y el cáncer (Tuse et al., 2015). En plantas de N. benthamiana mediante el uso de vectores virales de la familia Geminiviridae, se ha expresado el anticuerpo monoclonal específico $(\mathrm{mAb})$ contra el enterovirus 71 murino, D5, a concentraciones altas dentro de los seis días posteriores a la infiltración con Agrobacterium GV3101 (Rattanapisit et al., 2019). El anticuerpo quimérico cD5 producido mantuvo su actividad de unión in vitro y una neutralización de alta afinidad contra el EV71, una dosis de $10 \mu \mathrm{g} / \mathrm{g}$ de peso corporal de mAb cD5 ofreció una protección del 100\% contra la infección con EV71 en ratones. Los vectores basados en virus de plantas se han modificado para silenciar genes diana en diversas especies de plantas, caracterizar las funciones génicas y ayudar a la elucidación de vías biosintéticas endógenas (Robertson, 2004). Además, varios estudios demostraron el enorme potencial de vectores virales para la reingeniería del metabolismo de las plantas mediante la expresión de enzimas activas y factores de transcripción (Kumagai et al., 1995; Mozes-Koch et al., 2012; Zhang et al., 2013; Sainsbury et al., 2012; Geisler et al., 2013; Majer et al., 2017). Una gran desventaja de los vectores virales es que la mayoría de estos sistemas no pueden coexpresar varias proteínas heterólogas en la misma célula. Sin embargo, la ingeniería de las rutas metabólicas suele requerir la expresión coordinada de varias enzimas. Para superar esta limitación, se desarrolló un vector viral derivado del virus del grabado del tabaco (TEV, género Potyvirus) que permitía la expresión simultánea de varias proteínas recombinantes en cantidades equimolares y en la misma localización celular (Figura 1) (Bedoya et al., 2010a; Bedoya et al., 2010b).

El genoma de los potyvirus (género Potyvirus, familia Potyviridae) consiste en un ssRNA+ de aproximadamente 10.000 nucleótidos (nt) encapsidados en viriones largos y flexibles (UrcuquiInchima et al., 2001; Ivanov et al., 2014; Revers et al., 2015). El RNA genómico está unido 
covalentemente en su extremo 5' a la proteína viral enlazada al genoma (VPg) y su extremo 3' está poliadenilado. El genoma contiene una ORF principal, que codifica una poliproteína precursora larga que se procesa dando como resultado aproximadamente diez proteínas multifuncionales maduras. El genoma de los potyvirus alberga otras ORFs más pequeñas que codifican P3N-PIPO, y en algunas especies P3N-PISPO (Chung et al., 2008; Mingot et al., 2016). Después de la entrada en la célula huésped, el genoma viral sirve como molde para la traducción de las proteínas virales, ejecutada por los ribosomas de la célula huésped. Posteriormente, la poliproteína es procesada por las tres proteasas codificadas por el virus: P1, HC-Pro y NIaPro. P1 y HC-Pro catalizan su propia escisión en sus respectivos extremos carboxilo (Carrington et al., 1989a, Carrington et al., 1989b, Verchot et al., 1991), mientras que NIaPro corta en los sitios restantes en cis y en trans, reconociendo un motivo de secuencia de siete aminoácidos (Carrington et al., 1990). Las proteínas sintetizadas se expresan principalmente en el citoplasma, pero algunas proteínas virales se acumulan tanto en el citoplasma como en el núcleo en forma de cuerpos de inclusión (Riedel et al., 1998). Tradicionalmente, los potyvirus han atraído el interés de los biotecnólogos de plantas, en primer lugar, debido a su estrategia de expresión del genoma que permite la producción de proteínas heterólogas en una cantidad equimolar (Dolja et al., 1992; Carrington et al., 1993) y, en segundo lugar, debido a que el genoma de potyvirus permite la inserción de genes heterólogos en varios sitios (Beauchemin et al., 2005). Normalmente, los genes de interés están flanqueados por sitios de reconocimiento de las proteasas virales. Después de la traducción, estos sitios son reconocidos por la proteasa, que ayuda a la liberación de las proteínas heterólogas de la poliproteína (Carrington et al., 1993). Hay dos posiciones frecuentemente usadas para la inserción de secuencias heterólogas: entre P1 y HC-Pro y entre NIb y CP (Fernández-Fernández et al., 2001; Beauchemin et al., 2005; Dietrich y Maiss, 2003), pero el extremo amino terminal de la poliproteína también se puede usar (Majer et al., 2014), lo que facilita la distribución de las proteínas recombinantes a diferentes localizaciones subcelulares (Majer et al., 2015). La posición de inserción de los cDNA foráneos tiene un efecto importante sobre la acumulación de las proteínas (Arazi et al., 2001; Beauchemin et al., 2005; Dolja et al., 1997; German-Retana et al., 2000).

Bedoya et al. (2010b) desarrollaron un vector de expresión génica basado en el TEV, mediante la sustitución del cistrón $\mathrm{NIb}$ por un casete que permite la coexpresión de múltiples proteínas heterólogas en plantas de tabaco. El sistema aprovecha el hecho de que el cistrón NIb se puede complementar en trans (Li y Carrington, 1995), permitiendo la inserción de una secuencia 
foránea en su lugar. Esta estrategia también es beneficiosa desde un punto de vista de biocontención, ya que minimiza el riesgo de escape del virus recombinante. El vector viral basado en TEV logró la expresión simultánea, colocalizada y equimolar de tres proteínas fluorescentes insertando sus cDNAs en el casete de expresión, flanqueadas por secuencias de procesamiento proteolítico de NIaPro. Gracias a este avance, los investigadores se propusieron expresar varias enzimas de la ruta metabólica de las antocianinas e inducir productos naturales valiosos en plantas. Con este vector se expresaron los factores de transcripción Delila y Rosea1 de Antirrhinum majus y se consiguió una gran acumulación de antocianinas en el tejido de tabaco infectado (Figura 1). El aumento del contenido de antocianinas confirió una coloración púrpura intenso a las hojas. Posteriormente, se descubrió que la expresión única de Rosea1 entre los cistrones NIb y CP del genoma viral es suficiente para producir antocianinas rojas, y Rosea1 se propuso como un marcador visual para rastrear la infección viral en las plantas (Bedoya et al., 2012).

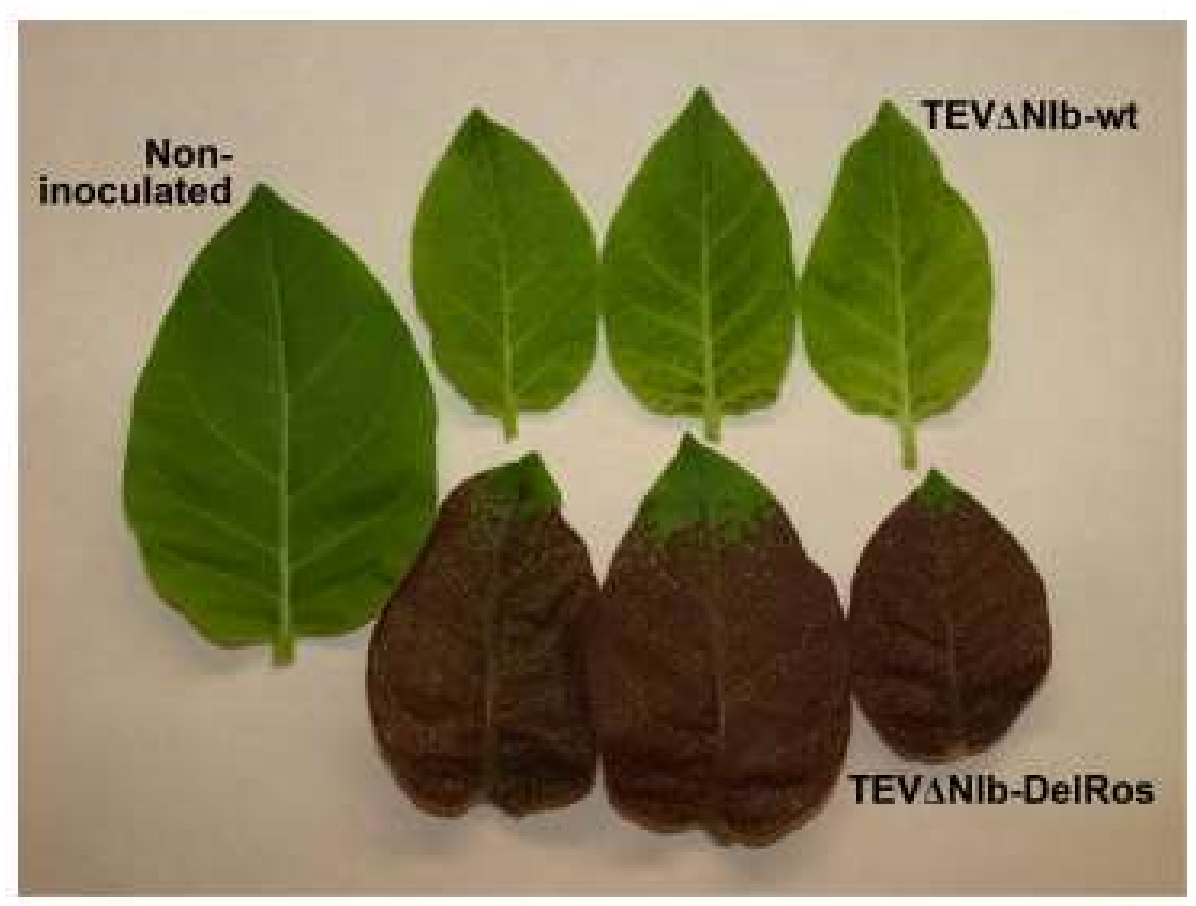

Figura 1. Expresión de los factores de transcripción Delila y Rosea1 de Antirrhinum majus en plantas transgénicas de N. tabacum que expresan la NIb del TEV. Arriba y abajo, hojas sistémicas sintomáticas de tres plantas inoculadas con el virus silvestre y recombinante, respectivamente. Se incluye una hoja como control no inoculado (izquierda). Extraída de Bedoya et al., 2010b. 


\section{USO DE GENES REPORTEROS PARA EL SEGUIMIENTO DE LAS INFECCIONES VIRALES EN PLANTAS}

El uso de genes reporteros supuso un gran avance en el estudio de los virus de plantas, permitiendo la detección de la presencia viral en el tejido, así como la cuantificación y el control de la infección. Uno de los primeros sistemas reporteros que se utilizó en virología de plantas fue el basado en la acción de la enzima $\beta$-glucoronidasa (GUS). Esta enzima es una hidrolasa que cataliza la escisión de una variedad de $\beta$-glucurónidos, siendo uno de los más empleados el denominado X-gluc (5-bromo-4-cloro-3-indolyl-beta-D-glucorónido), que como producto de su hidrólisis da un color azul intenso en tejidos. Comercialmente podemos encontrar distintos tipos de sustratos dependiendo del tipo de detección que se va a emplear (histoquímicos, espectrofotométricos y fluorométricos). La técnica se basa en la fusión del gen de interés con GUS y detección de la actividad de la enzima como expresión del gen (Jefferson et al., 1987). Este sistema permitió la visualización in vivo de la localización subcelular de proteínas virales y de la extensión del virus a través de la planta infectada (Restrepo et al., 1990; Chapman et al., 1992; Dolja et al., 1992). Sin embargo, la detección de la actividad de GUS requiere una técnica destructiva que limita los estudios de la dinámica de infección por virus de plantas. La visualización in vivo de proteínas en biología celular se logró primero gracias a la proteína verde fluorescente (GFP) de la medusa Aequorea victoria y sus muchos derivados (Day y Davidson, 2009; Matz et al., 2002). Esta proteína fue descubierta en los años sesenta por Osamu Shimomura y, desde entonces, se ha clonado y expresada en casi todos los organismos, incluyendo bacterias, hongos, invertebrados, vertebrados y plantas (Prasher et al., 1992; Tsien, 1998). La técnica se basa en la capacidad única del cromóforo de la GFP para exhibir fluorescencia brillante en el espectro del verde cuando se expone a luz con longitud de onda en el espectro azul o violeta, sin necesidad de cofactores u otras proteínas adicionales. La GFP está compuesta de 11 cadenas $\beta$ antiparalelas las cuales forman un cilindro muy compacto cuyo centro alberga el fluoróforo (Ormo et al., 1996). Los extremos amino y carboxilo están expuestos en la superficie de la proteína, lo que lo hace ideal como gen marcador sin afectar la integridad estructural de la proteína y el fluoróforo. Este está compuesto por los aminoácidos 65-67 y se forma mediante una reacción de oxidación en el centro del cilindro que es catalizada por la propia GFP (Heim et al., 1994). Posteriormente, se realizaron sucesivas modificaciones de secuencia de este gen reportero, que mejoraron la termoestabilidad, aumentaron la fluorescencia y alteraron sus propiedades espectrales, obteniendo variantes de GFP más útiles para trabajar en plantas (Stewart, 2001). Se descubrió que la reacción de oxidación que forma 
el cromóforo es cuatro veces más rápida que en la versión silvestre si se introduce la mutación S65T en la secuencia peptídica de la GFP (enhanced GFP, EGFP) (Heim et al., 1995). Las proteínas fluorescentes permitieron la observación de la dinámica de propagación del virus a través de los tejidos vivos (Baulcombe et al., 1995; Oparka et al., 1997; Ruiz-Ramon et al., 2019) y facilitaron muchos descubrimientos sobre las proteínas de los virus vegetales (Tilsner y Oparka, 2010; Tian et al., 2014). El uso conjunto de varias proteínas fluorescentes con diferentes longitudes de onda de excitación y emisión, hizo posible la covisualización de varias proteínas virales al mismo tiempo, así como la colocalización de factores virales y del huésped (Caplan et al., 2008; Wei et al., 2010b; Wei et al., 2010a). Sin embargo, existe una dificultad asociada al empleo de GFP, debido a que requiere equipo especializado, de microscopía de fluorescencia o de emisión láser, lo que impone limitaciones importantes en los estudios de dinámica viral, particularmente en experimentos a gran escala o de campo.

En el reino vegetal se observan una amplia gama de colores debido a que reacciones metabólicas endógenas de las plantas dan como resultado pigmentos naturales coloreados. Estos pigmentos, gracias a sus vívidos colores, también pueden servir como reporteros de la infección viral. Exceptuando las clorofilas, los pigmentos vegetales se pueden clasificar en: antocianinas, carotenoides y betalaínas (Tanaka et al., 2008). Las tres clases de pigmentos actúan como señales visibles para atraer insectos, pájaros y animales para la polinización y la dispersión de semillas. También protegen a las plantas del daño causado por los rayos ultravioleta (UV) y la luz visible. Las antocianinas son una clase de flavonoides y están ampliamente distribuidas en el reino vegetal. Estos pigmentos son solubles en agua, se sintetizan en el citosol y se acumulan en vacuolas. Las antocianinas tienen un amplio espectro de colores que van del rojo al azul, dependiendo de la estructura del pigmento, los iones metálicos y el pH. Los carotenoides son una subclase de terpenoides solubles en lípidos y que se sintetizan en el cloroplasto. Confieren una coloración de amarilla a roja a las frutas, flores y raíces. Las betalaínas son pigmentos vegetales solubles en agua derivados de la tirosina, que otorgan colores del amarillo al rojo exclusivamente en plantas del orden Caryophyllales. Se clasifican en dos grupos: las betacianinas rojo-violetas y las betaxantinas amarillas (Tanaka et al., 2008). Las betalaínas tienen gran estabilidad, independencia del $\mathrm{pH}$ y altas propiedades antioxidantes, por ello se usan ampliamente como suplementos dietéticos y como colorantes alimenticios (Azeredo, 2009). Debido a su valor económico y sus beneficios nutricionales, en los últimos años ha crecido el interés por descifrar su enigmático proceso biosintético para conseguir producirlas en mircroorganismos y plantas. Recientemente se ha demostrado que la 
expresión transitoria en un vector binario de los genes CYP76AD1, DODA1 y cDOPA5GT de Mirabilis jalapa y Beta vulgaris da lugar a la producción de betalaínas en plantas de la familia de las solanáceas (Polturak et al., 2016).

Los genes reporteros derivados de pigmentos vegetales son un gran avance en la biología de virus de plantas, puesto que se pueden observar a simple vista, no destruyen el tejido donde se expresan y se pueden cuantificar por métodos espectrofotométricos. Para el conocimiento de la ruta biosintética de las antocianinas se caracterizaron y estudiaron principalmente los genes de las plantas de maíz (Zea mays), de boca de dragón (Antirrhinum majus), y de petunia (Petunia hybrida) (Holton y Cornish, 1995). La biosíntesis de antocianinas está bajo el control de varias familias de genes reguladores a nivel transcripcional, como los factores de transcripción R2R3 MYB, hélice-bucle-hélice básica (bHLH) y proteínas de repetición WD40 (Tian et al., 2007). Las vías biosintéticas de antocianinas están estrechamente reguladas durante el desarrollo de la planta de una manera espacio-temporal, lo que requiere una combinación específica de factores de transcripción que forman un complejo ternario (Hichri et al., 2011). En A. majus, tres genes que codifican factores de transcripción relacionados con MYB, Rosea1, Rosea2 y Venosa, y dos genes que codifican proteínas bHLH, Delila y Mut, interactúan de una manera específica de tejido para regular la biosíntesis de antocianinas (Schwinn et al., 2006). Roseal en combinación con Delila se utilizaron previamente para aumentar la acumulación de antocianinas en frutos de tomate, confiriéndoles una coloración púrpura (Butelli et al., 2008). Bedoya et al. (2010) coexpresaron Roseal y Delila en plantas de N. tabacum con un vector de expresión basado en TEV que confirió coloración roja al tejido infectado (Figura 1). Sin embargo, la expresión del factor de transcripción de tipo MYB, Rosea1, de A. majus (220 aminoácidos, $25.7 \mathrm{kDa}$ ), una proteína cuyo tamaño es similar a la GFP, fue suficiente para inducir una pigmentación visible a simple vista. Rosea1 se propuso como un marcador visual para rastrear la infección viral y el movimiento en varias plantas huésped (Bedoya et al., 2010b Bedoya et al., 2012). Una ventaja remarcable del uso de Roseal como marcador visual es su estabilidad en el genoma viral durante el ciclo infeccioso y a través de pases sucesivos de planta a planta, y que la acumulación de antocianinas inducida por Roseal se correlaciona con la carga viral, por lo que puede considerarse como un indicador cuantitativo. Las antocianinas se pueden extraer fácilmente del tejido en metanol y se pueden cuantificar con precisión mediante medida colorimétrica. Estos hallazgos hacen que este marcador visual sea ideal para el monitoreo rápido de plantas en experimentos de campo y a gran escala. 
Para obtener información detallada de las limitaciones funcionales, estructurales y evolutivas de la organización del genoma de los potyvirus, se reubicó la proteína viral NIb del TEV a todas las posiciones intercistrónicas posibles de su genoma en el clon infeccioso que contenía el gen reportero Rosea1 (Majer et al., 2014) para poder monitorizar la infección viral. Solo los clones virales donde NIb se alojó en las dos primeras posiciones intercistrónicas fueron viables en plantas silvestres de tabaco (Majer et al., 2014). Con el TEV también se realizaron estudios de expresión de las enzimas de la ruta biosintética de los carotenoides de Pantoea ananatis reemplazando el cistrón NIb que fue suplementado en trans (Li and Carrington, 1995; Bedoya et al., 2010b). La expresión de un virus recombinante con la enzima fitoeno sintasa (crtB) de esta ruta produjo una reducción en la expresión de clorofilas y un aumento de la expresión de los carotenoides cloroplásticos, $\beta$-caroteno y luteína, produciendo una coloración amarilla en el tejido infectado (Majer et al., 2017). Para mostrar la sencillez de monitorización de la infección viral gracias a estos genes reporteros, Rosea1 (rojo) y crtB (amarillo), se construyeron los virus recombinantes TEV-Ros1 (Bedoya et al., 2012) y TEV-crtB donde el gen reportero flanqueado por sitios proteolíticos se insertó en el genoma del TEV entre las proteínas virales NIb y CP. La coexpresión de estos clones virales recombinantes en plantas de $N$. tabacum produce una coloración mixta detectable a simple vista, donde es posible diferenciar el tejido infectado por cada población viral (Majer et al., 2017) (Figura 2).

\section{SILENCIAMIENTO GÉNICO EN PLANTAS}

En plantas, el silenciamiento génico mediado por un RNA exógeno fue puesto de manifiesto en 1990 cuando se realizaron estudios de sobreexpresión del gen de la chalcona sintasa en petunias transgénicas para mejorar la pigmentación de los pétalos (Napoli et al., 1990; Van der Krol et al., 1990). Al contrario de lo esperado, las plantas con copias extra de dicho gen sufrieron despigmentación en sus flores, lo que indicó una cosupresión del gen introducido y del endógeno, ya que los niveles del mRNA se reducían. Otra evidencia de RNA exógeno como inductor de silenciamiento génico se obtuvo a partir de estudios sobre la resistencia a virus mediada por secuencias virales en plantas, donde la expresión de transgenes derivados de virus induce una degradación de RNA específica de secuencia que conduce a la resistencia al virus. La replicación de los virus de RNA produce RNA de doble cadena (dsRNA) mediante una RNA polimerasa dependiente de RNA (RdRP) viral. Esta molécula dispara el silenciamiento génico. Sin embargo, los virus responden con la expresión de supresores de silenciamiento (Hamilton y Baulcombe, 1999). Dos ejemplos bien conocidos son la proteinasa componente auxiliar (HC- 
Pro) de los potyvirus y la proteína p25 codificada por el virus X de la patata (PVX), que representan dos estrategias virales diferentes para suprimir el silenciamiento. HC-Pro es un supresor del silenciamiento altamente eficaz que puede mejorar la acumulación de una amplia gama de virus de plantas (Vance y Vaucheret, 2001). Previene tanto el silenciamiento génico inducido por virus (VIGS) como el silenciamiento de RNA inducido por transgén. La p25 de PVX es mucho menos efectiva para bloquear el silenciamiento que HC-Pro, y parece interferir con el silenciamiento sistémico (Voinnet et al., 2000). Un aspecto importante del silenciamiento de RNA en plantas es que puede activarse localmente y luego propagarse célula a célula o de forma sistémica (Voinnet, 2005; Kalantidis et al., 2008).
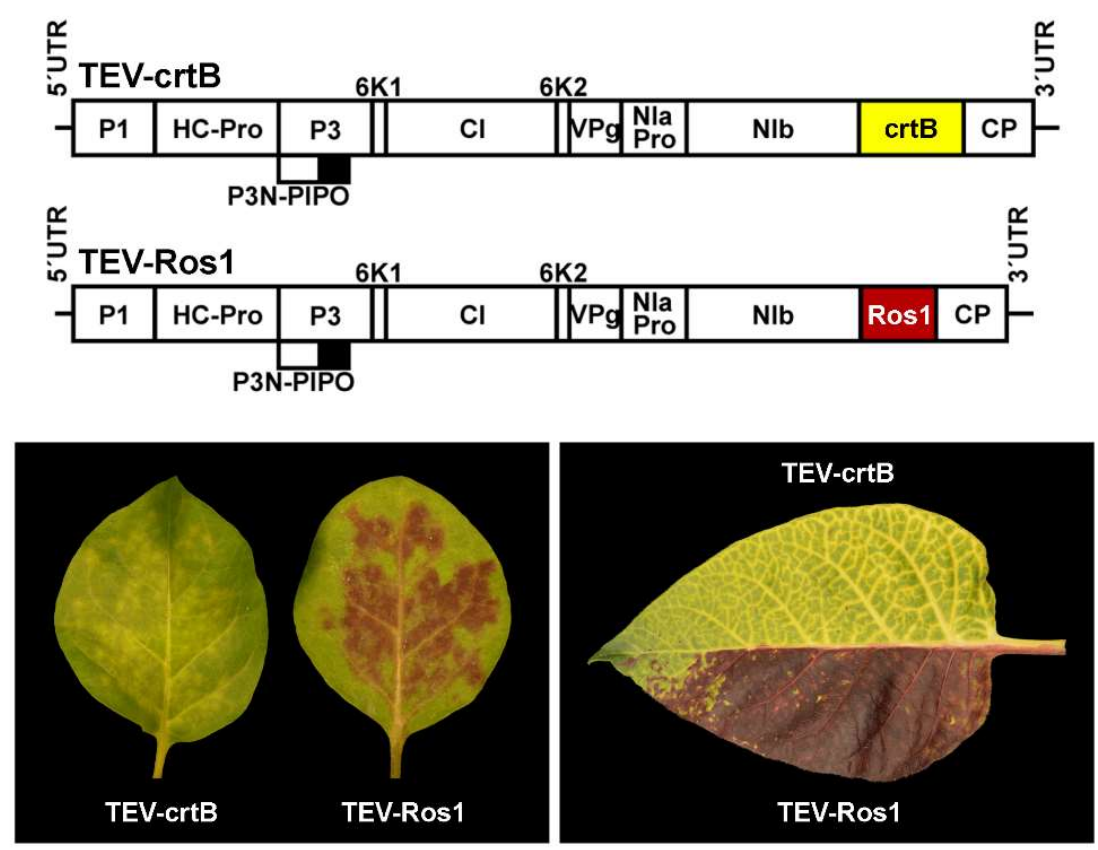

Figura 2. Monitorización simultánea de la coinfección de virus de plantas usando los marcadores crtB y Rosea1. Representación esquemática de los clones recombinantes TEV-crtB y TEV-Ros1. Los marcadores crtB y Rosea1 (Ros1) se representan por una caja amarilla y roja, respectivamente. El panel de abajo a la izquierda muestra la inoculación mecánica en hojas de plantas de tabaco con TEV-crtB y TEV-Ros1 7 días después de la inoculación. El panel de abajo a la derecha muestra una hoja de tabaco de nuevo crecimiento coinfectada con los dos virus recombinantes 12 días después de la inoculación. Extraída de Majer et al., 2017.

En plantas y otros organismos eucariotas existen rutas de inactivación génica específicas de secuencia (DNA o RNA) (Baulcombe et al., 2004), que regulan tanto a nivel transcripcional (transcriptional gene silencing, TGS) como postranscripcional (posttranscriptional gene silencing, PTGS) distintos procesos biológicos como la metilación del DNA, la respuesta génica en procesos de estrés biótico o abiótico, la modificación de la cromatina, el control de 
transposones y el mecanismo de defensa antiviral (Dunoyer y Voinnet, 2005; Li y Ding, 2005; Ding y Voinnet, 2007) (Figura 3). En el TGS la síntesis de RNA está disminuida debido a la metilación del promotor (Cogoni y Macino, 2000; Wassenegger et al., 1994), y el PTGS implica la degradación de RNA específica de secuencia (Fire, 1999). En el TGS el complejo efector (RNA-induced transcripcional silencing complex, RITS) (Verdel et al., 2004) es guiado hasta un DNA de secuencia complementaria al que se une, induciendo su metilación y bloqueando su transcripción, participando en la formación de heterocromatina (Chan et al., 2004; Wassenegger, 2005). En el PTGS una de las hebras de los pequeños RNAs (small RNAs, sRNAs), la hebra guía, se une a un complejo multiproteico (RNA-induced silencing complex, RISC) (Hammond et al., 2000) y lo guía hasta el RNA diana que es degradado o se bloquea su traducción mediante la actividad RNasa $\mathrm{H}$ del dominio Piwi de las endonucleasas Argonauta (AGO) (Baumberger y Baulcombe, 2005), gracias a la complementariedad de bases (Bartel, 2004; Brodersen et al., 2008). Ambas rutas de silenciamiento génico se desencadenan por la presencia de dsRNA u otros precursores similares que son procesados por una ribonucleasa de la familia de las RNasas tipo III, llamada Dicer (Dicer-like, DCL, en plantas), para generar sRNAs de entre 21 y $24 \mathrm{nt}$. En plantas, hay dos tipos de sRNAs dependiendo de su procedencia y nivel de actuación, los sRNAs de interferencia (siRNAs) provenientes de la degradación de agentes invasivos y los microRNAs (miRNAs) (Vaucheret et al., 2001), encargados de la regulación de la expresión de genes endógenos. Los dsRNAs desencadenantes del PTGS pueden generarse por transcripción en el núcleo celular o por la acción de una RNA polimerasa dependiente de RNA (RDR) sobre los RNAs generados tras el corte por de RISC o sobre otros RNAs aberrantes (Voinnet, 2008). Las enzimas RDR, además de generar moléculas inductoras, participan en la amplificación de la respuesta de silenciamiento. Los dsRNAs resultantes son digeridos por una DCL, generando nuevos sRNAs denominados sRNAs secundarios. Los miRNAs, sRNAs de 20 a 24 nt que se originan en el núcleo mediante el procesamiento por DCL1 de un transcrito endógeno altamente estructurado (Jones-Rhoades et al., 2006; Chapman y Carrington, 2007), ejercen su acción en el citoplasma bloqueando la traducción o induciendo la degradación del RNA complementario. La segunda ruta es inducida por RNAs de dobles cadena (dsRNAs) producidos por virus y por transgenes o genes endógenos con secuencias invertidas (Chapman y Carrington, 2007). Los dsRNAs, dependiendo de su procedencia son digeridos por DCL2 o por DCL4, que generan siRNAs de 22 y $21 \mathrm{nt}$, respectivamente. Si los dsRNAs son digeridos por DCL 3, se generan siRNAs de 24 nt que dirigen la metilación de DNAs de secuencia complementaria (TGS) (Xie et al., 2004). 
La planta modelo Arabidopsis thaliana tiene cuatro DCLs (DCL1-DCL4) (Deleris et al., 2006) de localización nuclear, exceptuando DCL2 que es citoplasmática (Moissard y Voinnet, 2006). DCL1 produce miRNAs a partir de precursores con estructuras de tallo-asa, y la mayoría de los miRNAs tienen funciones cruciales en el crecimiento y desarrollo de las plantas (Park et al., 2002, Kurihara y Watanabe, 2004). Los otros tres DCL (DCL2-DCL4) producen siRNA a partir de dsRNA largos (Xie et al., 2004, Henderson et al., 2006). Tanto DCL3 como DCL4 tienen funciones importantes in vivo. Los siRNAs de $24 \mathrm{nt}$ producto de DCL3 funcionan en TGS a través de la metilación del DNA dirigida por RNA (RdDM) para suprimir la activación de los transposones. Los productos de DCL4, siRNAs de 21 nt, funcionan en PTGS o RNAi a través de la escisión de mRNAs de secuencia específica o la inhibición traduccional para regular la expresión génica y defender contra las infecciones virales (Bologna y Voinnet 2014). Además de las funciones de los miRNA en el crecimiento y desarrollo de las plantas, muchos miRNA están involucrados en diversas respuestas al estrés biótico y abiótico (Jones-Rhoades y Bartel, 2004, Sunkar y Zhu, 2004). Se han descubierto papeles importantes de varios miRNAs en condiciones de deficiencia de nutrientes. Por ejemplo, miR395, miR398 y miR399 están sobreexpresados en condiciones de deficiencia de $\mathrm{S}, \mathrm{Cu}$ y $\mathrm{P}$, respectivamente (Hsieh et al., 2009).

Los siRNAs secundarios de plantas derivan de moléculas de dsRNAs largas sintetizadas por una RDR (Bartel, 2004; Baulcombe, 2004; Carthew y Sontheimer, 2009) a partir de RNA monocatenarios. La planta modelo $A$. thaliana posee seis RDR identificables (RDR1, RDR2, RDR3a, RDR3b, RDR3c y RDR6) (Wassenegger y Krczal, 2006). Las proteínas RDR1, RDR2 y RDR6 comparten el motivo DLDGD catalítico canónico C-terminal de las RDR eucariotas y tienen ortólogos en muchas especies de plantas (Wassenegger y Krczal, 2006). RDR1 es inducida por infecciones virales (Zabel et al., 1974), viroidales (Khan et al., 1986), y participa en la defensa frente a virus (Xie et al., 2001; Yu et al., 2003). Inicialmente, estas enzimas se estudiaron debido a su papel en el silenciamiento antiviral y transgénico de las plantas, pero cada vez es más evidente que tienen funciones moleculares adicionales, incluido el control de la estructura de la cromatina y metilación del DNA (RDR2), y la regulación de la expresión génica celular (RDR6). Las otras tres proteínas identificadas (RDR3, RDR4 y RDR5; también llamados RDR3a-RDR3c), poseen en el centro catalítico un motivo de DFDGD y se agrupan en un clado filogenético distinto. Hasta la fecha, a estas tres proteínas no se les ha asignado funciones. 


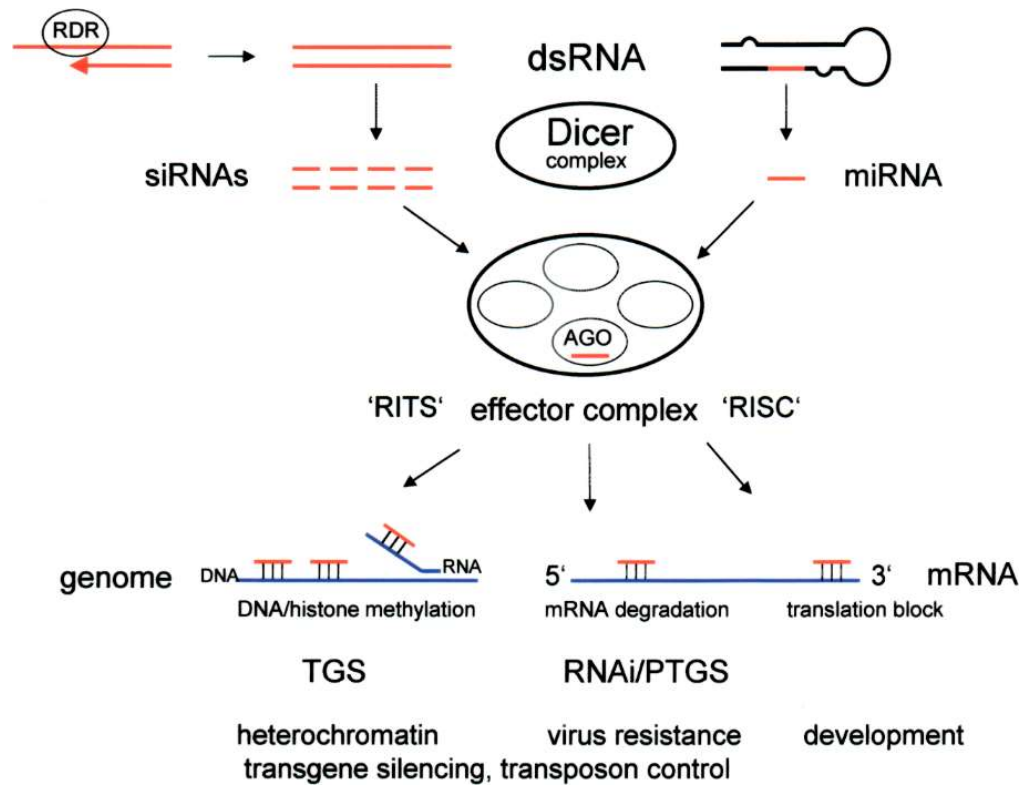

Figura 3. Silenciamiento mediado por RNA. Los sRNAs obtenidos del procesamiento de dsRNAs y RNAs muy estructurados mediante las enzimas Dicer, se incorporan en complejos efectores multiproteicos, como RISC y RITS, para iniciar la degradación de mRNA (RNAi/PTGS), inhibición de la traducción o TGS y modificación del genoma (metilación DNA e histonas). La hebra guía de los sRNAs se incorpora a las proteínas AGO y las guían hasta los complejos efectores apropiados. Este complejo es dirigido hasta el RNA diana promoviendo su degradación o modificación. Los siRNAs se originan a partir de dsRNAs o RNAs muy estructurados, y los miRNAs a partir de horquillas imperfectas de RNA codificadas en genomas de plantas y animales. La respuesta de silenciamiento se puede amplificar mediante las RDR. Tomado de Matzke y Matzke (2004).

De estas rutas de regulación de la expresión génica han surgido la técnica biotecnológica de interferencia mediada por RNA (RNAi), que consiste en suministrar dsRNAs que actúen como potentes activadores del mecanismo de silenciamiento con el fin de inducir la degradación específica de RNAs homólogos, siendo una herramienta muy útil para estudiar la función de genes (Waterhouse y Heliwell, 2003) o como herramienta para generar resistencia frente a plagas y patógenos (Haasnoot et al., 2007). Hace años la resistencia a virus se conseguía obteniendo plantas transgénicas que expresan dsRNAs del virus de interés, sobretodo RNAs con plegamiento en horquilla como consecuencia de tener repeticiones invertidas (hpRNAs). Otra opción alternativa al uso de plantas transgénicas es la aplicación directa de dsRNAs sintetizados exógenamente. Se comprobó que la coinoculación del virus del moteado suave del pimiento (PMMoV), del TEV y del virus del mosaico de la alfalfa (AMV), junto con sus dsRNAs homólogos, interfiere con la infección viral (Tellado y Díaz-Ruiz, 2001). Todos estos estudios motivaron la investigación de nuevos métodos de síntesis de dsRNAs para su uso en 
el tratamiento frente a infecciones virales, esto condujo a la producción de dsRNAs utilizando bacterias deficitarias en RNasa III (Tenllado et al., 2003).

\section{BIOLOGÍA SINTÉTICA}

El continuo desarrollo de la ingeniería genética ha dado lugar a una nueva disciplina llamada biología sintética que centra sus esfuerzos en construir circuitos genéticos con funciones nuevas que no se encuentran en la naturaleza. Los avances en el conocimiento del genoma y, con ello, la información de la red de interacciones entre las distintas partes génicas celulares y con el medio que las envuelve han hecho necesaria la aparición de esta nueva disciplina dentro de la biología, que centra sus esfuerzos en la obtención de células programables. El primer congreso de biología sintética se realizó en el Instituto Tecnológico de Massachusetts (MIT) en el 2004 donde se vaticinó un brillante futuro para esta nueva disciplina en los siguientes años. Aunque la biología sintética empieza a tener repercusión científica a finales del siglo XX con el diseño de circuitos génicos reguladores, ya se designó por primera vez en 1912 con la publicación del libro 'Biologie synthétique' de Leduc, aunque, teniendo en cuenta su año de publicación, no trataba aspectos tan amplios y complejos como los de la moderna disciplina. El desarrollo y establecimiento de este nuevo campo del conocimiento ha estado respaldado por todos los descubrimientos previos obtenidos por la biología de sistemas, que a través de modelos computacionales integra rutas génicas, interacciones de proteínas, circuitos a nivel celular, tisular y del organismo completo, tratando de predecir el comportamiento de los sistemas biológicos. La biología de sistemas es, en este sentido, la herramienta básica para que la biología sintética pueda diseñar nuevos productos biológicos o modificar otros ya existentes mediante ingeniería. Este objetivo se puede alcanzar mediante distintas tecnologías como la expansión del código genético, el diseño de microorganismos con genoma mínimo, el diseño de circuitos genéticos, la ingeniería genética in silico o la evolución dirigida (Tabla 1).

Todos los organismos biológicos por sencillos que parezcan tienen complicados mecanismos endógenos para adaptarse al medio que los rodea. La respuesta a estas condiciones externas se rige principalmente por genes, proteínas y RNAs que se coordinan mediante una red de regulación para dar una respuesta celular apropiada. Entender dicha respuesta es un arduo trabajo de comprensión de los mecanismos que relacionan lo que ocurre dentro y fuera de la célula con el comportamiento de la misma, y esto es necesario para avanzar en el desarrollo de circuitos genéticos lógicos que actúen a nivel molecular y generen la respuesta sintética 
esperada. Las plantas gracias a su capacidad de producción fácil, barata y segura de productos de interés biológico (Phoolcharoen et al., 2011), su crecimiento autótrofo y su rico metabolismo secundario (Verpoorte y Memelink, 2002) deberían ser un claro candidato para desarrollar circuitos de biología sintética, aunque actualmente la mayoría de desarrollos en este campo se han centrado en otro grupos taxonómicos (Ausländer et al., 2012; Siuti et al., 2013).

El campo de la biología sintética ha crecido enormemente en los últimos años (Cameron et al., 2014). El diseño de circuitos genéticos sintéticos ha centrado el interés de muchos grupos de investigación y las publicaciones al respecto han ido aumentando. El primer circuito genético natural fue descubierto hace más de 50 años en el Instituto Pasteur por F. Jacob y J. Monod (Willson et al. 1964), y consistía en un sistema de genes que intervienen en la digestión de la lactosa en Escherichia coli. En estudios de crecimiento diaúxico, estos investigadores observaron que E. coli consume preferentemente glucosa, procesando después lactosa. Este cambio metabólico está regulado por un mecanismo de dos partes en el operón lac. Cuando en el organismo bacteriano hay lactosa, la enzima $\beta$-galactosidasa es producida para metabolizarla, y en ausencia de lactosa, el represor lac inhibe la producción de esta enzima para prevenir procesos ineficientes dentro de la célula. En biotecnología, el operón lac es muy útil para controlar mecanismos de producción de proteínas recombinantes según la presencia o no de azúcares. Los genes para producir las proteínas se introducen en un plásmido bajo el control del promotor lac permitiendo sólo su producción cuando se agrega isopropil- $\beta-\mathrm{D}-1-$ tiogalactopiranósido (IPTG) al medio. En este tipo de circuito génico, el promotor puede tener asociado una secuencia reguladora $(\mathrm{R})$ donde se pueden unir moléculas represoras o activadoras de la transcripción del DNA (Savageau, 2001) (Figura 4). A partir de esta sencilla unidad de transcripción se construyen los circuitos génicos y redes de regulación complejas que son conectadas entre ellas mediante secuencias reguladoras para reprimir o inducir la expresión génica y, por tanto, la producción de proteínas. En el año 2000, Jim Collins y su estudiante de posgrado Tim Gardner crearon el primer interruptor biestable en E. coli, compuesto por una red reprimible de promotores donde el tránsito entre los estados se genera mediante inducción química o térmica. Como sistema de detección utilizaron la GFP. El comportamiento de los circuitos génicos es equivalente al de los circuitos electrónicos realizando operaciones lógicas o Booleanas.

Otro de los primeros circuitos genéticos desarrollados en E. coli fue un oscilador publicado en Nature por Michael Elowitz y Stanislas Leibler en el año 2000. Este oscilador consiste en un 
ciclo de retroalimentación formado por tres genes conectados, de modo que cada gen reprime al siguiente gen del ciclo, y a su vez es reprimido por el gen anterior. La detección del comportamiento de la red se obtiene mediante microscopía de fluorescencia gracias a la GFP. Desde estos primeros trabajos, la biología sintética ha ido sumando avances y ha adquirido un puesto privilegiado como disciplina en el campo de la investigación. Tantos han sido los esfuerzos que de los primeros objetivos de poder conseguir diseñar células sintéticas y poder programarlas se ha llegado al ambicioso reto de crear vida artificial como en el estudio que se publicó en 2016 en la revista Science. El grupo de Venter presentó una bacteria del tipo mycoplasma, apodada JCVI-syn3.0, en la que en una célula preexistente se insertó un genoma sintético de 473 genes compatible con la vida y con la replicación. Sin embargo, estas nuevas células sólo pueden subsistir en medios de laboratorio ricos en azúcares y otros nutrientes, ya que su genoma no está preparado para hacer frente a condiciones adversas. En paralelo a estos avances, se han realizado estudios en diferentes sistemas naturales para establecer nuevas funciones en las células, para resolver problemas aplicados como, por ejemplo, en las plantas, la producción de $\beta$-caroteno en arroz a través del redireccionamiento metabólico (Ye et al., 2000) o la detección de explosivos con una ruta de transducción de señal sintética (Antunes et al., 2011).
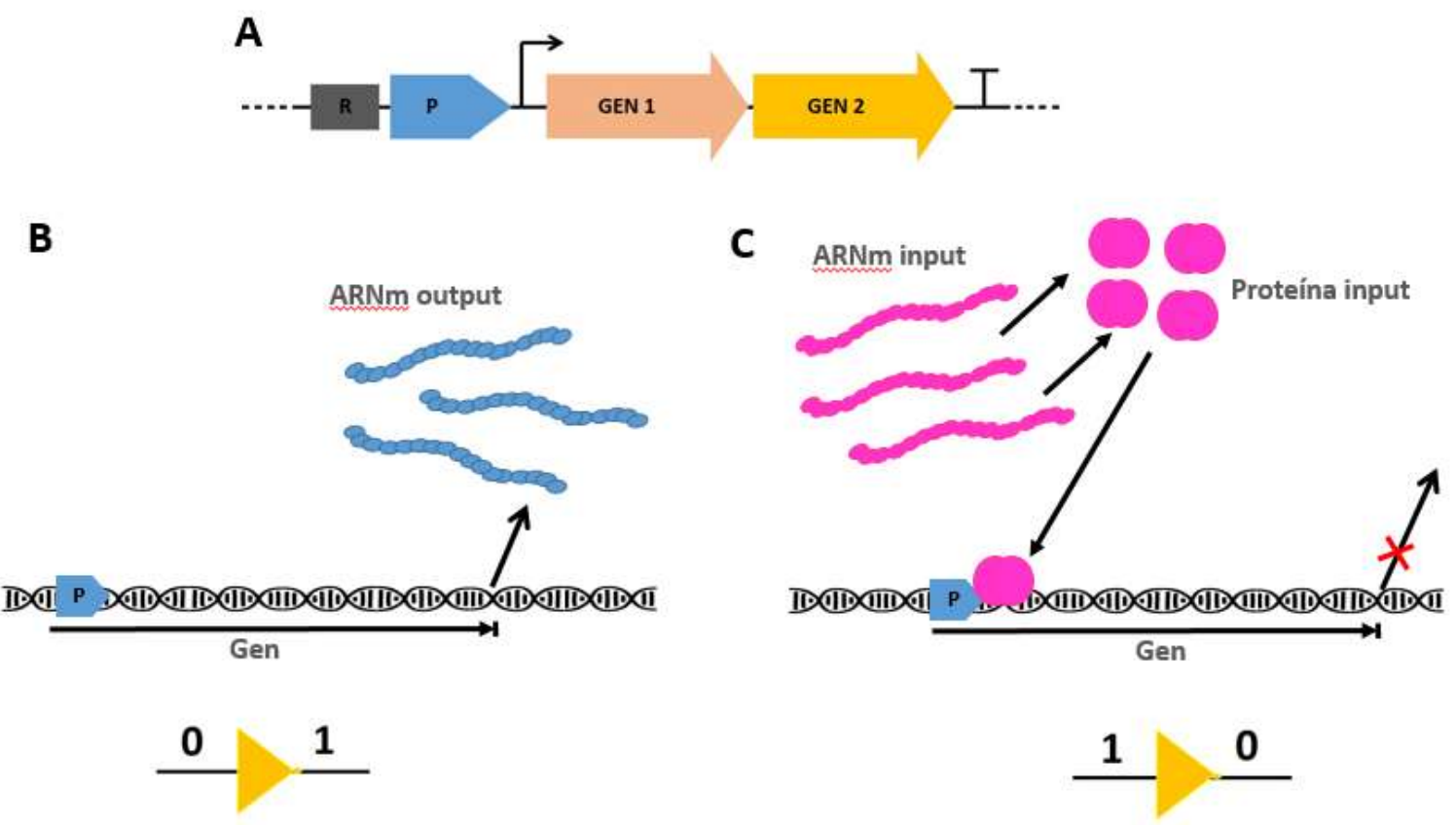

Figura 4. A) Unidad simple de transcripción. B) Respuesta operador genético básico NOT. No hay mRNA de entrada, por lo que la célula transcribe el gen a un mRNA de salida. C) Respuesta operador genético básico NOT. El RNA input está presente, por lo que este es traducido a una proteína input, que se une específicamente al promotor del gen e impide la síntesis del RNA output. Adaptado de Weiss et al., 2003. 
Tabla 1. Algunas tecnologías propias de biología sintética.

\begin{tabular}{|c|c|c|c|}
\hline TECNOLOGÍA & VENTAJAS & LIMITACIONES & EJEMPLOS \\
\hline $\begin{array}{l}\text { Expansión del } \\
\text { código genético }\end{array}$ & $\begin{array}{l}\text { Obtención de proteínas sintéticas } \\
\text { que incorporan nuevos aminoácidos } \\
\text { en su secuencia que les confieren } \\
\text { nuevas propiedades. }\end{array}$ & $\begin{array}{l}\text { Limitaciones en la obtención de bases } \\
\text { que codifiquen para un aminoácido } \\
\text { que no exista en la naturaleza. }\end{array}$ & $\begin{array}{l}\text { Wang et al., } 2001 \\
\text { Sismour et al., } 2005\end{array}$ \\
\hline Circuitos genéticos & $\begin{array}{l}\text { Diseño de microorganismos } \\
\text { programables mediante genes } \\
\text { capaces de realizar operaciones } \\
\text { lógicas a la carta. }\end{array}$ & $\begin{array}{l}\text { Estudio previo de las unidades } \\
\text { básicas que formaran los circuitos } \\
\text { genéticos. }\end{array}$ & Willson et al., 1964 \\
\hline Genoma Mínimo & $\begin{array}{l}\text { Creación de microorganismos } \\
\text { artificiales como sistemas de } \\
\text { producción simples, eficientes y } \\
\text { programables. }\end{array}$ & $\begin{array}{l}\text { Estudio de los genes mínimos para } \\
\text { crear organismos autónomos. }\end{array}$ & Venter et al., 2003 \\
\hline Evolución Dirigida & $\begin{array}{l}\text { Fabricación de nuevos proteínas } \\
\text { basándose en métodos evolutivos de } \\
\text { selección de clones de más interés. }\end{array}$ & $\begin{array}{l}\text { Creación de librerías de genes en } \\
\text { microorganimos. }\end{array}$ & Dan Ferber, 2004 \\
\hline $\begin{array}{l}\text { Ingeniería genética } \\
\text { in silico }\end{array}$ & $\begin{array}{l}\text { Modelos teóricos para predecir el } \\
\text { comportamiento de sistemas } \\
\text { complejos. }\end{array}$ & $\begin{array}{l}\text { Requerimiento de softwares muy } \\
\text { potentes. }\end{array}$ & Paul François y Vicent Hakim, 2003 \\
\hline
\end{tabular}

En 2019 el grupo de Jason Chin en Cambridge lograron recodificar el genoma de E. coli, aproximadamente a una escala 4 veces mayor que la descrita hasta el momento. Este E. coli reprogramado se llamó Syn61, ya que en vez de los 64 codones que se utilizan en la naturaleza para codificar los 20 aminoácidos canónicos, utiliza solo 6, demostrando la viabilidad de la vida con un número reducido de codones (Fredens et al., 2019). Los nuevos genomas reprogramados podrían sintetizar nuevas enzimas, proteínas y fabricar nuevos productos químicos para el avance de la medicina, la alimentación y la industria. El primer genoma generado computacionalmente se llamó Caulobacter ethensis-2.0 y se creó simplificando el código genético de la bacteria Caulobacter crescentus (Venetz et al., 2019). Reconstruyeron el genoma esencial de esta bacteria reescribiéndolo mediante síntesis química y estudiaron la información genética de sus genes esenciales. Redujeron de 6290 a 799 el número de características genéticas codificadas para generar una bacteria más eficiente. Mediante mutagénesis por transposón analizaron la funcionalidad biológica, revelando que 432 genes esenciales de C. eth2.0, son iguales en funcionalidad a los genes naturales. No existe como organismo vivo, pero es un gran avance para llegar a obtener moléculas totalmente sintéticas.

En definitiva, las aplicaciones de la biología sintética se centran en áreas donde la biotecnología tradicional no ha podido dar respuestas por falta de tecnología adecuada. El reto principal de 
esta disciplina es la integración de disciplinas alejadas entre sí para converger en una ciencia que aporte la visión más compleja de la vida. Algunos de los campos donde se centra el desarrollo actual de la biología sintética son la biorremediación y los biosensores, y otros como la medicina personalizada y la terapia génica presentan excelentes perspectivas para su desarrollo. Y algo más ambicioso, el Genome Project-Write (GP-Write), que dirigen Jef Boeke y George Church, pretende sintetizar en diez años todos los cromosomas humanos. 


\section{OBJETIVOS}



1. Analizar la contribución de las RNasas Dicer-like (DCL) de Nicotiana benthamiana en la defensa frente al virus del mosaico amarillo del calabacín (ZYMV) utilizando un sistema reportero basado en el factor de transcripción Roseal de la ruta de las antocianinas.

2. Desarrollar una versión recombinante del virus $\mathrm{Y}$ de la patata etiquetado con el factor de transcripción Rosea1 (PVY-Ros1) para monitorizar la infección por parte de este virus y producir antocianinas en plantas biofactoría de tabaco.

3. Desarrollar circuitos genéticos en plantas capaces de realizar operaciones lógicas, basados en la actividad de las proteasas NIaPro de los potyvirus y la producción de antocianinas derivada de la actividad Rosea1. 
CAPÍTULO I 

Dicer-like 4 is involved in restricting the systemic movement of Zucchini yellow mosaic virus in Nicotiana benthamiana

Teresa Cordero, ${ }^{1}$ Lidia Cerdán, ${ }^{1}$ Alberto Carbonell, ${ }^{1}$ Konstantina Katsarou, ${ }^{2}$ Kriton Kalantidis, ${ }^{2}$ and José-Antonio Daròs ${ }^{1}$

${ }^{1}$ Instituto de Biología Molecular y Celular de Plantas (Consejo Superior de Investigaciones Científicas-Universidad Politécnica de Valencia), 46022 Valencia, Spain; ${ }^{2}$ Institute of Molecular Biology and Biotechnology, Foundation for Research and Technology; and Department of Biology, University of Crete, Heraklion, Crete, Greece

Corresponding author: J. A. Daròs

E-mail: jadaros@ibmcp.upv.es 


\section{ABSTRACT}

Zucchini yellow mosaic virus (ZYMV) induces serious diseases in cucurbits. To create a tool to screen for resistance genes, we cloned a wild ZYMV isolate and inserted the visual marker Roseal to obtain recombinant clone ZYMV-Ros1. While in some plant-virus combinations Rosea1 induces accumulation of anthocyanins in infected tissues, ZYMV-Ros1 infection of cucurbits did not lead to detectable anthocyanin accumulation. However, the recombinant virus did induce dark red pigmentation in infected tissues of the model plant Nicotiana benthamiana. In this species, ZYMV-Ros1 multiplied efficiently in local inoculated tissue but only a few progeny particles established infection foci in upper leaves. We used this system to analyze the roles of Dicer-like (DCL) genes, core components of plant antiviral RNA silencing pathways, in ZYMV infection. ZYMV-Ros1 local replication was not significantly affected in single $D C L$, nor in double DCL2/4 and triple DCL2/3/4 knock-down lines. ZYMV-Ros1 systemic accumulation was not affected in knock-down lines DCL1, DCL2 and DCL3. However in DCL4, and also in DCL2/4 and DCL2/3/4 knock-down lines, ZYMV-Ros1 systemic accumulation dramatically increased, which highlights the key role of DCL4 in restricting virus systemic movement. The effect of DCL4 on ZYMV systemic movement was confirmed with a wild-type version of the virus.

\section{RESEARCH ARTICLE}

When plant viruses manage to enter an initial cell in their hosts, frequently with the help of a vector organism, they express and replicate their genomes to produce a progeny that first move cell to cell to reach the host vascular tissue, and then moves long-distance to distal areas. During this process, viruses hijack multiple elements, complexes and structures from host plants. They must also surpass all barriers and neutralize plant defensive responses. Viral and host components establish a complex interaction network that frequently leads to infection and disease response, but to resistance at other times. One of the main goals of plant virology is to understand this network in order to be able to modify the equilibrium to favor resistance.

Plants use RNA-mediated gene silencing pathways to fight invading viruses (Hamilton and Baulcombe, 1999). Plant Dicer-like (DCL) RNases recognize virus-specific double-stranded or highly-structured RNAs to produce 21-24 nucleotide (nt) small interfering RNA (siRNA) duplexes (Aliyari and Ding, 2009; Zhang et al., 2015). One of the strands is selectively loaded 
by an Argonaute (AGO) protein to guide the RNA-induced silencing complex (RISC) to target and repress sequence complementary viral RNAs (Carbonell and Carrington, 2015). The amount of viral double-stranded RNA that triggers the antiviral RNA silencing pathways in the host plant is amplified by RNA-dependent RNA (RDR) polymerase activities by using viral siRNAs as primers (Wang et al., 2010). In order to counteract this defensive response, evolution has shaped the proteins dedicated to suppress RNA silencing in virtually all plant viruses (Csorba et al., 2015).

Zucchini yellow mosaic virus (ZYMV) is a prominent pathogen of many plant species of the family Cucurbitaceae, which includes different important crops (Lecoq and Desbiez, 2012). It was first isolated in Italy in 1973 (Lisa et al., 1981), although it is currently present worldwide (Desbiez and Lecoq, 1997). ZYMV belongs to the genus Potyvirus in the family Potyviridae, and its genome consists of approximately 10,000 nt long single-stranded RNA molecules of plus polarity that encodes two versions of a large polyprotein (Wu et al., 2010). The genomic RNA of potyviruses (genus Potyvirus) is covalently attached at its 5' end to a viral protein genome-linked (VPg), contains a polyadenylated tail at its $3^{\prime}$ end, and is encapsidated by approximately 2000 units of the viral coat protein (CP) in an elongated and flexuous virion (Revers and García, 2015). Potyviral proteins, which include the P1 protease, the helper component protease (HC-Pro), the P3 protein and P3N-PIPO, small hydrophobic polypeptide $6 \mathrm{~K} 1$, the cylindrical inclusion $(\mathrm{CI})$ protein, a second small hydrophobic polypeptide $6 \mathrm{~K} 2$, the nuclear inclusion $a$ (NIa) protein, which is further split in its two VPg and protease (NIaPro) domains, viral RDR polymerase or nuclear inclusion $b$ (NIb) protein and the CP (Fig. 1A), are produced from a regulated cascade of proteolytic processing through the activity of three viral proteases: P1, HC-Pro and NIaPro.

For purpose of obtaining a viral clone to facilitate screening for resistance in cucurbitaceous plants, we cloned a wild isolate of ZYMV and constructed a recombinant clone that expresses the snapdragon (Antirrhinum majus L.) Roseal marker gene, which activates anthocyanins, a class of flavonoid pigments, biosynthesis and allows the visual tracking of viral infection in different plant species (Bedoya et al., 2012). Anthocyanin accumulation is cell-autonomous and only occurs in those cells infected by the marked virus in which Roseal is expressed. The amount of anthocyanins correlates with viral load (Bedoya et al., 2012). Unlike fluorescent protein markers, pigment accumulation in this system is clearly visible to the naked eye (Majer et al., 2013). We observed that this tool proved quite useless in zucchini (Cucurbita pepo L.) 
and other cucurbits, ZYMV natural hosts, given a negligible accumulation of colored anthocyanins in infected tissues. However in experimental host Nicotiana benthamiana Domin,
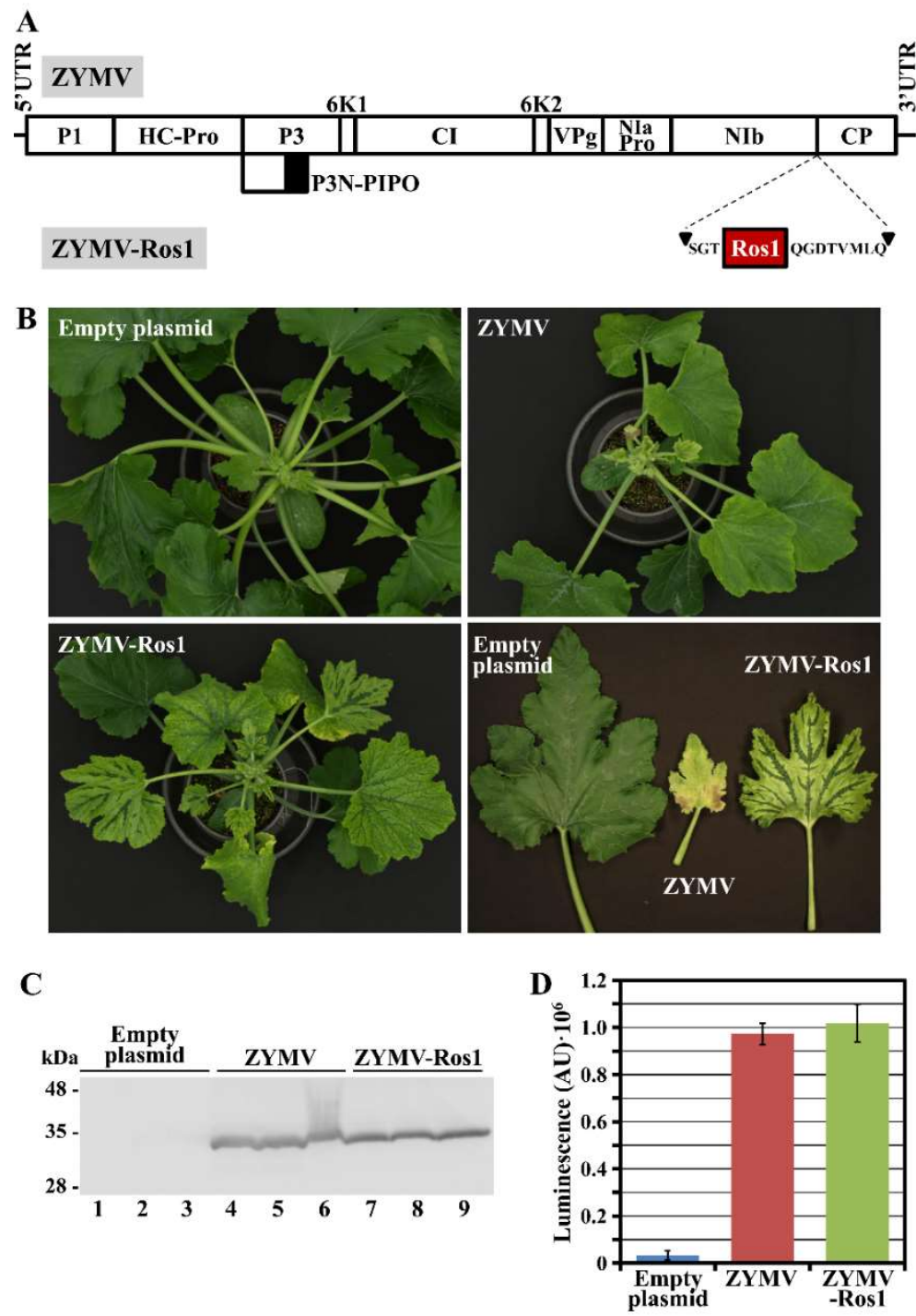

Fig. 1. Symptoms induced by ZYMV and ZYMV-Ros1 in zucchini plants. A, Schematic representation of the ZYMV genome. Lines represent the 5' and 3' untranslated regions (UTR) and boxes represent the different viral cistrons as indicated. In ZYMV-Ros1, a cDNA that codes for A. majus Rosea1 was inserted between cistrons NIb and $\mathrm{CP}$. The cDNA included sequences that corresponded to extra amino and carboxy terminal peptides, as indicated, to mediate proteolytic release from the polyprotein. B, Pictures of representative zucchini plants agroinoculated with the empty binary plasmid, ZYMV or ZYMV-Ros1. To better appreciate symptoms, a picture of selected leaves is also shown. All the pictures were taken at 21 dpi. C, Western blot analysis of ZYMV CP accumulation in upper non-inoculated tissues of three independent plants agroinoculated with the empty plasmid (lanes 1 to 3), wild-type ZYMV (lanes 4 to 6) and ZYMV-Ros1 (lanes 7 to 9) at 15 dpi. The position and size (expressed in $\mathrm{kDa}$ ) of marker proteins are indicated at the left of the panel. $\mathbf{D}$, Bar graph representing the average ZYMV CP accumulation, quantified as luminescence arbitrary units (AU) by Western blot, in the upper noninoculated tissues of the previously described (panel C) zucchini plants. Error bars represent the standard error median. 
efficient virus local multiplication in inoculated tissues, and an inefficient systemic movement to distal tissues, were observed for the recombinant clone. We reasoned that the Rosea l-marked ZYMV clone and $N$. benthamiana combination could represent an excellent experimental system to study the virus sequence determinant and the host factors involved in the longdistance movement of this virus. By means of this novel tool, we particularly aimed to analyze the differential contributions of the four $N$. benthamiana DCL genes, core components of the host RNA silencing pathways, in virus systemic movement in $N$. benthamiana. Our results show that while individual $D C L$ genes barely contributed to inhibit virus multiplication in inoculated tissues, DCL4 plays a major role in restricting ZYMV systemic movement in $N$. benthamiana.

\section{RESULTS}

\section{A ZYMV infectious clone that includes the visual Rosea1 marker suboptimally moves}

\section{long-distance in $N$. benthamiana}

The Rosea1 marker system has been successfully applied to several combinations of viruses and host plants (Bedoya et al., 2012). However, it cannot be considered as a universal system as it is based on the activity of an heterologous transcription factor on a host endogenous metabolic pathway. We wondered whether this system could be applied to ZYMV to track infection in cucurbitaceous plants. If this were the case, the system would be a most valuable tool to facilitate high-throughput screening for resistance in cucurbit breeding programs. To this end, we cloned a wild ZYMV isolate from a zucchini plant (cultivar Scallop), grown in 2013 in Horta de Vera (Valencia, east Spain), which presented severe infection symptoms. Two internal cDNA fragments from the viral genome were amplified by reverse transcription (RT)polymerase chain reaction (PCR), whereas the 5' and 3' terminal cDNAs were amplified by a rapid amplification of cDNA ends (RACE) strategy. The sequence information from $\mathbf{S 1}$ all these cDNAs served to design a set of primers (see Supplementary Table) to amplify the whole genome of the Vera isolate of ZYMV in three cDNA fragments flanked by the recognition site of a type-IIS restriction enzyme. These fragments were finally assembled into a binary plasmid in which the full-length ZYMV cDNA was flanked by Cauliflower mosaic virus (CaMV) 35S promoter and a 50 nt-long poly(A) stretch followed by CaMV $35 \mathrm{~S}$ terminator. This ZYMV cDNA was sequenced and the resulting full-length sequence was deposited in GenBank as the Vera isolate of ZYMV (GenBank accession number KX499498). A standard nucleotide BLAST search displayed the highest identity with a Taiwanese isolate 
of ZYMV (GenBank accession number AF127929.2) (Lin et al., 2001). An alignment analysis using ClustalW exhibited 94.6\% nucleotide identity between both sequences with 517 nucleotide differences.

Next we inserted a cDNA that corresponded to the A. majus Roseal coding region between ZYMV NIb and CP cistrons to construct the recombinant virus clone ZYMV-Ros1 (Fig. 1A). Roseal cDNA was flanked by sequences that code for amino acids that complement both sides of the native $\mathrm{NIb} / \mathrm{CP}$ proteolytic site to mediate the release of Rosea1 from the viral polyprotein (Fig. 1A and Supplementary Fig. S1). The Agrobacterium tumefaciens clones transformed with plasmids to express ZYMV (pGZYMV) or ZYMV-Ros1 (pGZYMV-Ros1), as well as the empty binary plasmid (pG35Z), were used to inoculate zucchini plants (cultivar MU-CU-16). All the plants agroinoculated with ZYMV or ZYMV-Ros1 became infected. The pictures taken on day 21 post-inoculation (dpi) show the severe symptoms induced by the Vera isolate of ZYMV (Fig. 1B and Supplementary Fig. S2). The plants infected by ZYMV-Ros 1 showed milder symptoms (Fig. 1B and Supplementary Fig. S2). A Western blot analysis showed that accumulation of both viruses in upper non-inoculated leaves of zucchini plants was similar (Fig. 1C and D). Unfortunately, the infected tissues of these plants did not show the expected reddish pigmentation that Rosea1 induces in other species. Similar results were obtained with a different cucurbit species, melon (Cucumis melo L.) plants of the Piel de Sapo cultivar (Supplementary Fig. S3).

To confirm that recombinant clone ZYMV-Ros1 expressed a functional copy of Rosea1, we agroinoculated $N$. benthamiana plants using the same $A$. tumefaciens cultures. ZYMV replicates with no symptoms in the inoculated leaves of $N$. benthamiana and, depending on the strain, moves systemically and induces latent infection (Desbiez and Lecoq, 1997). We previously showed that this species produces intense reddish pigmentation when infected with several viruses that express Rosea1, including other potyviruses like Tobacco etch virus (TEV) (Bedoya et al., 2012). Unlike the tissues agroinoculated with the empty vector or with ZYMV, tissues agroinoculated with ZYMV-Ros 1 displayed intense dark red pigmentation at 7 dpi (Fig. 2A and Supplementary Fig. S4A). This result indicates that ZYMV-Ros1 expresses a functional Roseal transcription factor that efficiently induces accumulation of reddish anthocyanins in $N$. benthamiana. As expected, none of the $N$. benthamiana plants showed infection symptoms (Supplementary Fig. S4B). However, a prolonged observation of these plants revealed that, in those agroinoculated with ZYMV-Ros1, some pigmented foci constantly 
appeared to be scattered on the upper non-inoculated leaves (Fig. 2B). This result suggests that the Vera isolate of ZYMV is able to move long-distance in $N$. benthamiana, but inefficiently. It is noteworthy that we detected infection foci on the upper non-inoculated leaves due to the vivid pigmentation induced by the Roseal transcription factor. We realized that the combination of the ZYMV-Ros1 clone and N. benthamiana could represent a convenient experimental system to analyze elements involved in ZYMV systemic movement.
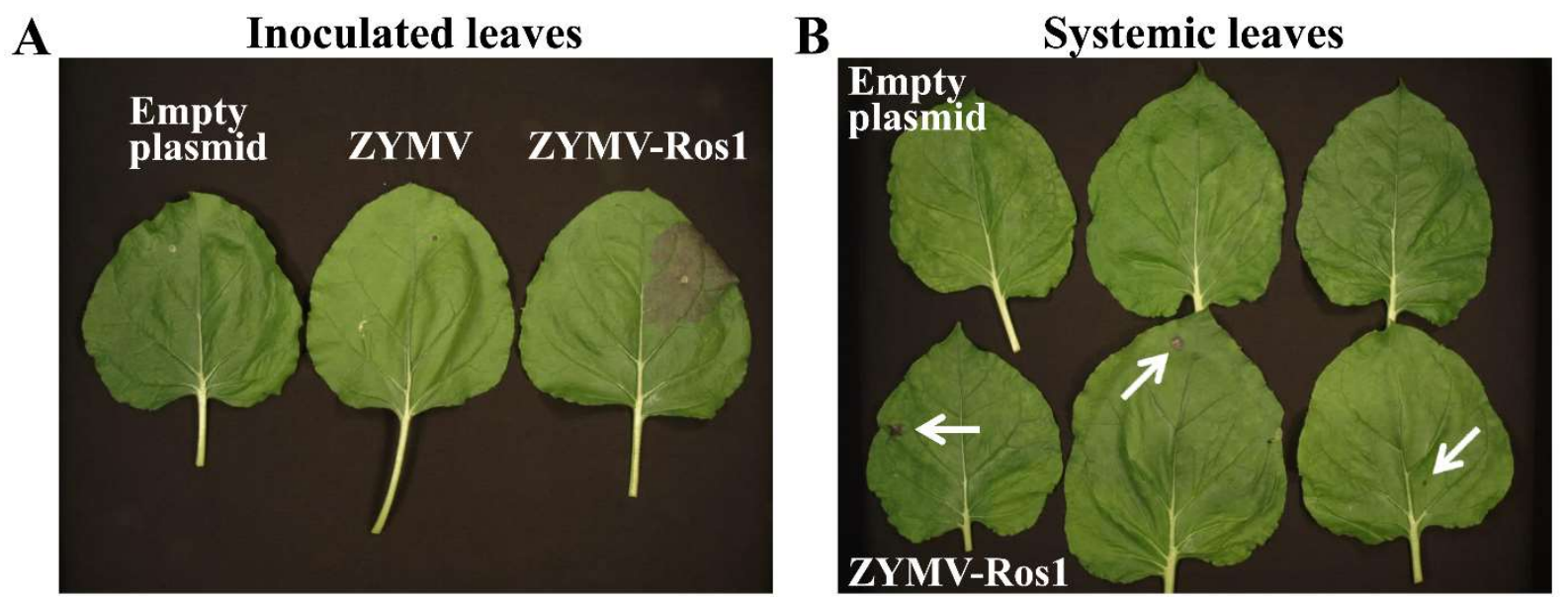

Fig. 2. ZYMV-Ros1 suboptimally moves long-distance in N. benthamiana. A, Pictures were taken at 7 dpi and are representative of leaves agroinoculated with the empty plasmid, ZYMV or ZYMV-Ros1. B, Comparison of systemic leaves from three $N$. benthamiana plants agroinoculated with the empty binary plasmid or ZYMV-Ros1. Arrows indicate the pigmented infectious foci induced by ZYMV-Ros1 in systemic leaves. The picture was taken at 21 dpi.

Analysis of the contribution of the four host DCL genes to ZYMV systemic movement in N. benthamiana

With this experimental system at hand, we next aimed to study the effect of the four $N$. benthamiana DCL genes, which are core components of host RNA-mediated silencing pathways, on the systemic movement of ZYMV in this species. To this end, we used a set of $N$. benthamiana transgenic plants in which the different $D C L$ genes were down-regulated by expressing specific hairpin constructs (Dadami et al., 2013; Katsarou et al., 2016). RTquantitative PCR (RT-qPCR) and northern blot hybridization analyses of transgenic lines DCL1.13i, DCL2.11i, DCL3.10i and DCL4.9i showed a specific reduction in the DCL1, DCL2, $D C L 3$ and DCL4 mRNAs levels, respectively. Apart from the plants knock-down in the single $D C L$ genes, we also used line DCL2/4.5i, which expresses a hairpin to simultaneously downregulate DCL2 and DCL4, and line DCL3.10(x)2/4.5i, the heterozygous progeny that results 
from crossing DCL3.10i as a female and DCL2/4.5i as a male (Dadami et al., 2013; Katsarou et al., 2016).

We first questioned whether these genes had an effect on virus accumulation in inoculated tissue. For this purpose, we agroinoculated two leaves of three $N$. benthamiana plants that corresponded to the wild-type and the DCL knock-down lines DCL1.13i, DCL2.11i, DCL3.10i, DCL4.9i, DCL2/4.5i and DCL3.10(x)2/4.5i. The agroinoculated tissues were harvested at 6 dpi and proteins were extracted. ZYMV CP was analyzed by electrophoretic separation followed by Western blot using a specific anti-CP antibody (Fig. 3). Wild-type non-inoculated controls were added to the analysis. The quantification of the Western blot signals is summarized in Supplementary Table S2. Fig. 3 shows the three Western blots, as well as the graph of ZYMV $\mathrm{CP}$ accumulation in the agroinoculated tissue of the different $N$. benthamiana lines. According to the amount of CP, ZYMV-Ros1 accumulation in the inoculated tissues of the DCL1.13i, DCL2.11i, DCL4.9i and DCL2/4.5i lines was similar to that of the wild-type plants. ZYMVRos 1 accumulation was lower in the DCL3.10i line (0.6-fold on average) and higher in the DCL3.10(x)2/4.5i line (1.75-fold on average) compared with the wild-type plants (Fig. 3B). However, none of the differences in ZYMV-Ros1 accumulation between wild-type and each of the $D C L$ knock-down lines was statistically significant $(P<0.05$ for all pair-wise Student's $t$ test comparisons).

Next we analyzed the effect of the $D C L$ down-regulation on ZYMV systemic movement in $N$. benthamiana. Sets of three plants that corresponded to the wild-type and the different knockdown lines were agroinoculated with ZYMV-Ros1 in three leaves. In the $N$. benthamiana lines DCL1.13i, DCL2.11i and DCL3.10i, we obtained the same outcome previously obtained in the wild-type plants. Very few infection foci were detected in the upper non-inoculated tissues. However in the N. benthamiana line DCL4.9i, and in lines DCL2/4.5i and DCL3.10(x)2/4.5i, ZYMV-Ros1 was able to efficiently move long-distance into the upper non-inoculated tissue (Fig. 4A and B). Supplementary Fig. S5 shows the pictures of the three independent inoculated plants, as well as the selected leaves, which corresponded to each line. We previously showed that anthocyanin accumulation very precisely correlates with viral load in Roseal-marked viruses (Bedoya et al., 2012). Therefore, in order to make a more quantitative estimate of ZYMV-Ros1 systemic movement in all these plants, we harvested all the aerial tissues above the agroinoculated leaves at $27 \mathrm{dpi}$ and quantified the accumulation of reddish anthocyanins by a spectrophotometric analysis (Fig. 4C and Supplementary Table S3). 

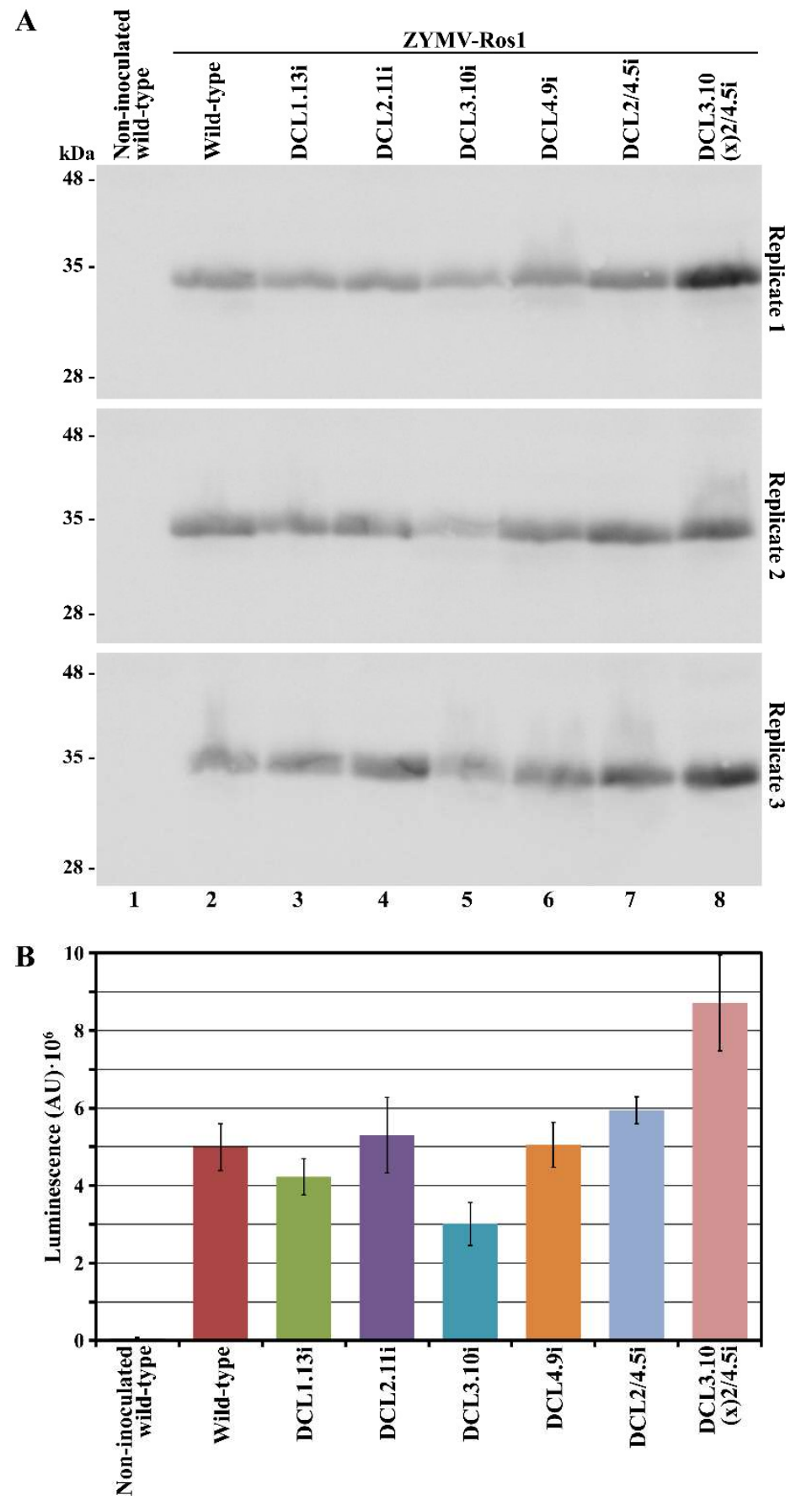

Fig. 3. Accumulation of ZYMV-Ros1 in the agroinoculated tissues of wild-type $N$. benthamiana plants and the lines down-regulated in different $D C L$ genes. A, Triplicate Western blot analysis of ZYMV CP using a specific antibody conjugated to alkaline phosphatase and a luminogenic reaction. Proteins were separated by SDS-PAGE. Lanes 1 and 2, non-inoculated and infected wild-type plants, respectively; lanes 3 to 8, infected DCL downregulated lines, as indicated. The position and size (in $\mathrm{kDa}$ ) of marker is indicated at the left of the panel. B, Bar graph of the average ZYMV CP accumulation, quantified as luminescence AU, in the agroinoculated tissues of three independent $N$. benthamiana plants that corresponded to the wild-type or DCL down-regulated lines, as indicated. Tissue from a non-inoculated wild-type plant was also analyzed as a control. Error bars represent the standard error median. 
While anthocyanin accumulation in the DCL1.13i, DCL2.11i and DCL3.10i lines was negligible and indistinguishable from the wild-type plants, the aerial tissues of lines DCL4.9i, DCL2/4.5i and DCL3.10(x)2/4.5i accumulated substantial amounts of these pigments (Fig. 4C). It was noteworthy that the anthocyanin accumulations in the double DCL2/4.5i and in the triple DCL3.10(x)2/4.5i knock-down lines were 1.8- and 2.9-fold higher, respectively, on average than in the single knock-down DCL4.9i line. Taken together, these results support a crucial role of DCL4 in restricting the systemic movement of ZYMV in $N$. benthamiana that may be functionally complemented by DCL2 and DCL3. To confirm this result, a similar experiment was conducted with wild-type ZYMV under same experimental conditions. Western blot and RT-qPCR analyses of virus accumulation at 28 dpi in the whole upper noninoculated tissues confirmed the crucial role of DCL4 in restricting virus systemic movement (Fig. 4D and E).

\section{DISCUSSION}

The goal of this research was to create a tool to facilitate screening ZYMV resistance in the breeding programs of cucurbit plants. Although the initial aim failed, we were able to generate a convenient experimental system to analyze the contribution of ZYMV genetic determinants and host factors to viral systemic movement, which should ultimately help to understand and develop resistance to infection by this virus.

\section{A new Mediterranean isolate of ZYMV that mostly resembles a sequence variant from Taiwan}

We constructed an infectious clone from a Spanish isolate of ZYMV that infected a zucchini plant. Our clone mostly resembles sequence variant AF127929.2, which has been reported in Taiwan and was isolated in 1993 from sponge gourd (Luffa cylindrical Roem.) (Lin et al., 2001). The two variants differ in 517 nucleotide positions ( $94.6 \%$ identity), including the insertion of a $U$ at position 9465, which corresponds to the 3' UTR. Our finding of a 2013 Mediterranean isolate that mostly resembled a 1993 Taiwanese sequence variant, which belong to phylogenetic group A-IV, mainly composed of East Asian isolates (Coutts et al., 2011), supports the easy worldwide dispersion of this virus. 

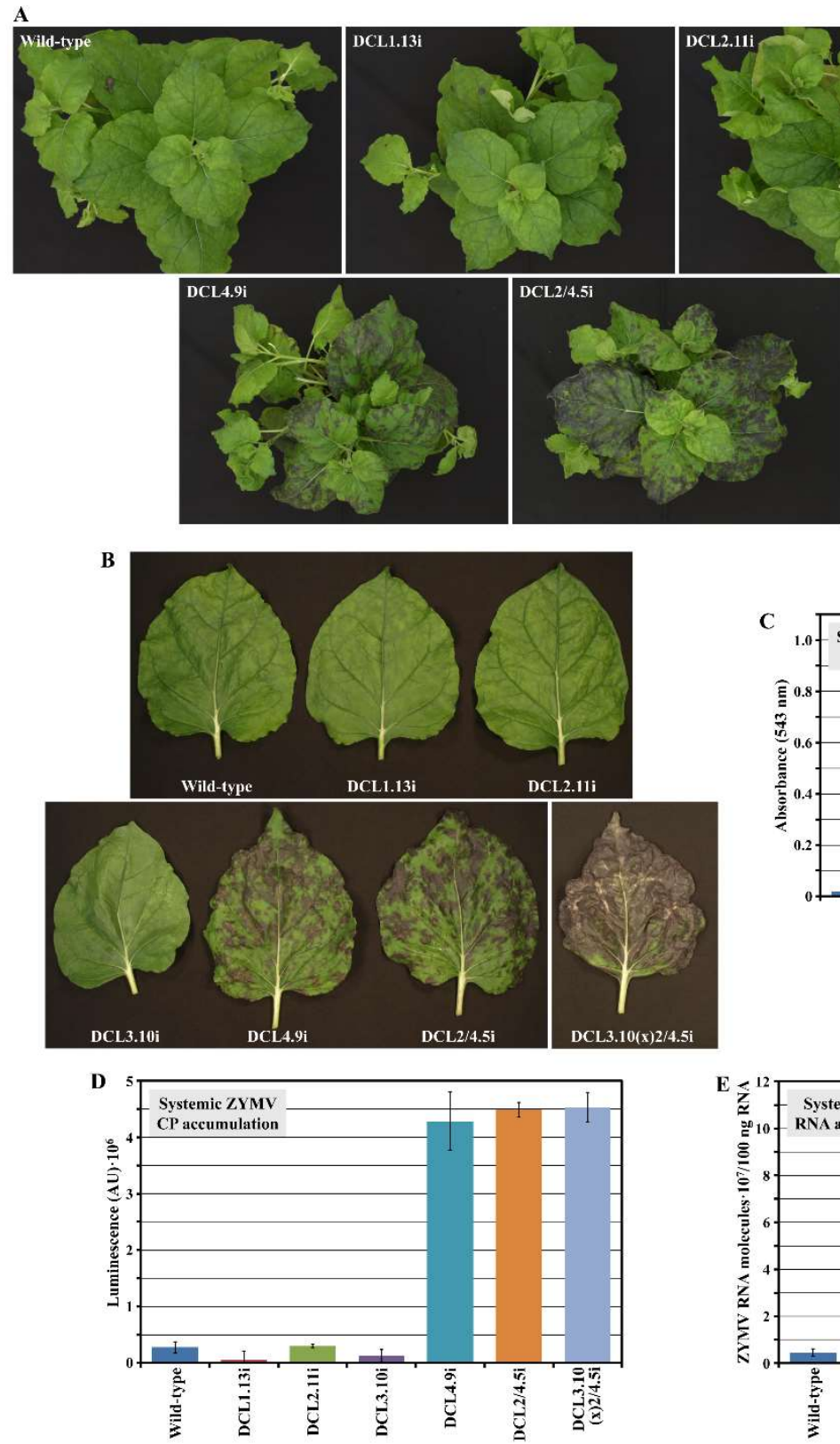
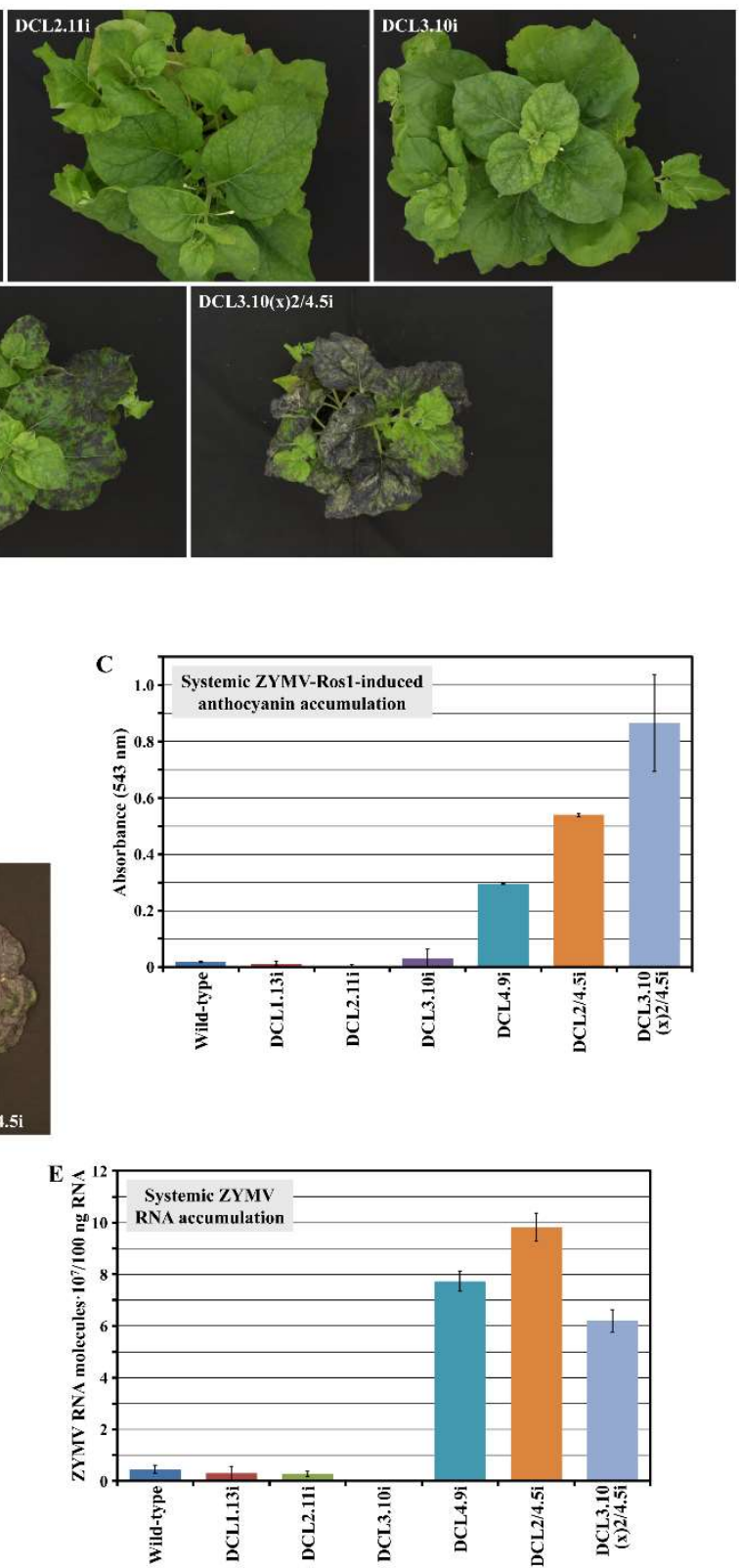

Fig. 4. ZYMV moves long-distance more efficiently in the $N$. benthamiana plants in which DCL4 is downregulated. A, Pictures of the $N$. benthamiana plants that corresponded to the wild-type and $D C L$ knock-down lines, as indicated, and agroinoculated with ZYMV-Ros1. Pictures were taken at $27 \mathrm{dpi}$. B, Pictures of selected leaves of the plants shown in panel A. C, Bar graph representing the average anthocyanin accumulation, measured as absorbance at $543 \mathrm{~nm}$, in the aerial tissues of three wild-type and $D C L$ knock-down $N$. benthamiana plants, as indicated. The average background absorbance of three wild-type non-inoculated controls was subtracted. $\mathbf{D}$ and E, Bar graphs representing the average ZYMV CP accumulation quantified by Western blot analysis (D), and the average ZYMV RNA accumulation quantified by RT-qPCR (E), in the upper non-inoculated leaves of three wildtype and $D C L$ knock-down $N$. benthamiana plants agroinoculated with wild-type ZYMV. Tissues were harvested 28 dpi. Error bars indicated standard error median. 


\section{The ZYMV-mediated expression of Rosea1 does not produce visible anthocyanin accumulation in cucurbit plants}

We constructed a recombinant ZYMV clone that expresses A. majus R2R3 MYB transcription factor Rosea1 (ZYMV-Ros1, Fig. 1A and Supplementary Fig. S1). This recombinant clone induced the accumulation of reddish anthocyanins in the infected tissues of $N$. benthamiana (Fig. 2 and Supplementary Fig. S3), but not in cucurbitaceous species like zucchini (Fig. 1B and Supplementary Fig. S2) or melon (Supplementary Fig. S3). Tomato plants engineered to over-express the two A. majus transcription factors Rosea 1 and Delila under the control of a fruit-specific promoter produced purple tomatoes with high anthocyanin content (Butelli et al., 2008; Su et al., 2016). In plants, anthocyanin biosynthesis is controlled at the transcriptional level by members of three protein families: R2R3 MYB transcription factors, bHLH transcription factors and WD repeat proteins. They interact to form a ternary complex that activates a series of genes that lead to anthocyanin biosynthesis and accumulation in vacuoles (Zhang et al., 2014). We previously showed that the virus-mediated expression of Roseal and Delila in tobacco tissues also induces the accumulation of large amounts of anthocyanins in infected tissues (Bedoya et al., 2010). Next we reported that the sole virus-mediated expression of Roseal suffices to induce pigment accumulation that is readily detectable to the naked eye in infected tissues in several host plant-virus combinations. This finding suggests that this transcription factor is a convenient marker to visually track plant virus infection and movement (Bedoya et al., 2012). In terms of the size, Roseal is only slightly larger than the most conventional reporter gene used in plant virology, green fluorescent protein (GFP) (Tilsner and Oparka, 2010). Although the impact of Rosea1 in recombinant virus fitness is stronger than that of GFP, the stabilities of both markers in the viral genome are similar (Majer et al., 2013). We succeeded in producing a visible reddish pigmentation of the infected tissues in solanaceous plants (N. benthamiana or Nicotiana tabacum L.), but also in the non-solanaceous Arabidopsis thaliana L. using recombinant potyviruses, such as TEV or Turnip mosaic virus (TuMV), and also with viruses like Tobacco mosaic virus or Potato virus $X$ that belong to different families (Bedoya et al., 2012). Narcissus mosaic virus (genus Potexvirus) has also been shown to induce visible pigment production in $N$. benthamiana plants, when expressing $A$. thaliana R2R3 MYB transcription factor AtMYB75 (PAP1) (Zhang et al., 2013). Lack of pigment accumulation in the tissues of cucurbitaceous plants infected with ZYMV-Ros1 may result from an incompatibility between $A$. majus Roseal and the endogenous companion transcription factors of the bHLH and WD repeat types. Not much is known about the flavonoid pathway in cucurbits. Other flavonoids, such as flavone derivatives, have been detected in cucumber 
(Cucumis sativus L.) and melon leaves (Krauze-Baranowska and Cisowski, 2001). Flavonol derivatives have also been reported in the reproductive organs of some cucurbits (Imperato, 1980). Naringenin chalcone is the main flavonoid that accumulates in the fruit rind of some yellow melon varieties (Tadmor et al., 2010; Feder et al., 2015).

Zucchini plants infected with ZYMV-Ros1 showed milder symptoms than those infected with wild-type ZYMV (Fig. 1B and Supplementary Fig. S2). Some leaves in these plants presented a distinctive beautiful pattern that consisted in dark green perinerval stripes on a light green background (Fig. 1B and Supplementary Fig. S2). The possibility that these distinctive symptoms might still arise from some unknown activity of the Roseal transcription factor cannot be ruled out.

\section{ZYMV-Ros1 inefficiently moves long-distance in $N$. benthamiana}

According to the anthocyanin production induced by the Roseal marker, we observed that ZYMV-Ros1 efficiently accumulated in the agroinoculated tissues of $N$. benthamiana plants, but very few particles from the progeny were able to establish systemic infection foci (Fig. 2 and Supplementary Fig. S4). As an alternative to agroinoculation, we obtained the same result from mechanical inoculation of $N$. benthamiana plants with an extract of ZYMV-Ros1-infected zucchini. It is worth noting that the visual marker was crucial for this observation since very few systemic infection foci kept appearing in the first weeks after inoculation. The Rosea1induced pigmented foci, which were directly observable without using specialized instrumentation such as a UV lamp (Bedoya et al., 2012), easily attracted our attention. It has been previously described that some ZYMV strains induce latent infection in N. benthamiana either systemically or in a limited manner to inoculated tissue (Lesemann et al., 1983; Wang et al., 1992; Desbiez and Lecoq, 1997).

We reasoned that the combination of our recombinant ZYMV-Ros1 virus and the $N$. benthamiana host could represent an excellent experimental system to study the virus genetic determinants and host factors involved in ZYMV systemic movement. N. benthamiana, particularly the lineage used in most research laboratories, is susceptible to a large number of plant virus species from very different taxonomic groups. This is most probably because this lineage, which was originally harvested in an extreme habitat of central Australia, is a natural rdrl mutant (Bally et al., 2015; Carbonell, 2015). Consequently, this species is frequently adopted as a model plant in many research works into plant viruses. In our system, the amount 
of viral particles capable of reaching upper non-inoculated tissues was easily determined by monitoring the dark red pigmentation of these tissues. The efficiency of viral systemic movement was also quantified in systemic tissues by counting infection foci or by measuring anthocyanin accumulation by a simple colorimetric analysis of methanol extracts. We previously showed that, for Rosea1-marked viruses, anthocyanin accumulation correlates with viral load in infected tissues (Bedoya et al., 2012). This experimental system should help to analyze genetic determinants in the virus genome that affect systemic movement. More importantly, this system should allow analyzing the host factors involved in ZYMV systemic movement. In this way, by inoculating knock-out or knock-down $N$. benthamiana mutants, host factors involved in favoring or restricting ZYMV systemic movement could be identified and analyzed. Similarly, by inoculating $N$. benthamiana plants in which the candidate factors from cucurbit species are expressed by stable genetic transformation or by transient expression through $A$. tumefaciens or viral vectors, the host factors that are recruited by the virus to mediate its systemic movement in the natural hosts could be screened. The identification and analysis of all these factors will provide an understanding of the mechanisms that underlie ZYMV systemic movement. These factors may also be used as targets to breed or engineer resistance in cucurbitaceous plants by blocking virus systemic movement.

\section{DCL4 is involved in restricting ZYMV systemic movement in $N$. benthamiana}

Since DCL proteins initiate the antiviral RNA silencing response in plants (Aliyari and Ding, 2009; Zhang et al., 2015), we used our new experimental system, based on ZYMV-Ros1 and $N$. benthamiana, to analyze the effects of $D C L$ genes on ZYMV systemic accumulation. $N$. benthamiana, like A. thaliana, encodes four DCL type-III RNases (Nakasugi et al., 2013). We took advantage of the availability of a recently generated collection of $N$. benthamiana RNAi transgenic lines, in which the different $D C L$ genes were down-regulated (Dadami et al., 2013; Katsarou et al., 2016). To better understand the role of these genes in ZYMV systemic movement, we first analyzed the effect of their down-regulations on ZYMV-Ros1 local multiplication in agroinoculated tissue (Fig. 3 and Supplementary Table S2). Interestingly, local accumulation of ZYMV-Ros1 was reduced (0.6-fold on average) in DCL3 single knockdown plants compared to that observed in wild-type plants. DCL3, which is primarily involved in antiviral defense against DNA viruses (Akbergenov et al., 2006), but also against RNA viruses as DCL4 surrogate (Deleris et al., 2006; Garcia-Ruiz et al., 2010), could be directly involved in ZYMV-Ros1 genome amplification or cell-to-cell movement or, alternatively, could regulate one or more host factors that favor virus multiplication. DCL3 activity may also 
have a negative effect on DCL2 and DCL4. In contrast, the single down-regulation of DCL1, DCL2 and DCL4, and the double down-regulation of DCL2 and DCL4, had no effect on ZYMV-Ros1 local accumulation, which apparently suggests that these three $D C L$ may be dispensable for local antiviral silencing. However in this context, we should consider that, unlike most studies in which viruses with mutations in silencing suppressors have been used (Ziebell and Carr, 2009), in our system ZYMV-Ros1 expresses a wild-type HC-Pro, which may mask the local antiviral effects of these particular $D C L$, as reported before for TuMV in $A$. thaliana (Garcia-Ruiz et al., 2010). The local accumulation of ZYMV-Ros1 increased (1.75fold on average) in the triple DCL2, DCL3 and DCL4 knock-down line compared to wild-type plants. This result suggests that these three antiviral $D C L$ genes possess co-operative antiviral activity against ZYMV-Ros1 in inoculated tissue, as previously observed in other plant-virus systems (Garcia-Ruiz et al., 2010; Andika et al., 2015).

Next we analyzed the effect of the DCL down-regulation on ZYMV-Ros1 systemic accumulation in upper non-infiltrated tissues. It is interesting to note that, while the single down-regulation of DCL4 did not affect ZYMV-Ros1 local multiplication, it had a dramatic effect by favoring virus accumulation in systemic tissue. This favorable effect was not observed in the single DCL1, DCL2 and DCL3 knock-down plants (Fig. 4, Supplementary Table S3 and Supplementary Fig. S5). Similar results were obtained using a wild-type ZYMV and analyzing virus systemic accumulation by Western blot (Fig. 4D) or by RT-qPCR (Fig. 4E). Therefore, the observations made for ZYMV-Ros1 are unlikely to be an artifact that resulted from an unexpected activity of the Rosea1 marker. In the case of ZYMV-Ros1, the analysis of the anthocyanin content in upper non-inoculated tissues revealed that virus systemic accumulation was enhanced in the double DCL2 and DCL4, and particularly in triple DCL2, DCL3 and DCL4 knock-down plants (Fig. 4, Supplementary Table S3 and Supplementary

Fig. S5). Taken together, these observations support a critical role of DCL4 in restricting ZYMV-Ros1 systemic accumulation in N. benthamiana, while DCL2 and DCL3 may functionally complement DCL4 in this role. Nonetheless, the specific mechanisms that explain how DCL4 hinders ZYMV systemic amplification in $N$. benthamiana still need to be determined. While it is conceivable that DCL4 prevents the entry or passage of viruses into the phloem, DCL4 may also restrict the virus from leaving vascular bundles, as reported for suppressor-deficient Turnip crinkle virus in A. thaliana (Deleris et al., 2006). In this scenario, as 21-nt siRNA duplexes can move long-distance in plants (Dunoyer et al., 2010), the DCL4dependent 21-nt siRNA duplexes could be the mobile silencing signal generated in inoculated 
tissue, which spread throughout the plant to prevent ZYMV from accumulating in the upper non-inoculated leaves (Mermigka et al., 2016). In any case, viral systemic movement in plants is a rather complex and prolonged process, and the specific mechanisms by which antiviral silencing blocks viral systemic spread need to be further clarified.

\section{MATERIALS AND METHODS}

\section{Amplification of ZYMV cDNAs}

Total RNA was purified by silica gel chromatography (Zymo Research) from a piece of symptomatic leaf from a zucchini plant (cultivar Scallop) growing in 2013 in Horta de Vera (Valencia, Spain), which showed typical symptoms of viral infection. From this RNA preparation, cDNAs were initially synthesized using RevertAid reverse transcriptase (Thermo Fisher Scientific) and oligodeoxynucleotide primers P1 and P4, designed on the basis of ZYMV GenBank reference sequence variant NC_003224.1. All primers used in this work are described Supplementary Table S1. The two cDNAs were amplified with Phusion high-fidelity DNA polymerase (Thermo Fisher Scientific) and primers P2 and P3, and P5 and P6. New cDNAs corresponding to the 5' and 3' viral ends were amplified by RACE. To amplify the 3' end, we took advantage of the native polyadenilate tail of ZYMV genomic RNA. Using primer P7, we synthesized a cDNA, which was next amplified by two subsequent PCR using primers P8 and P9, and P10 and P11. To amplify the 5' end, we first synthesized a cDNA using primer P12. A polytimidine tail was next added to the 3' end of this cDNA using calf thymus terminal transferase (Thermo Scientific). Finally, the 5' end was amplified in two consecutive PCR using primers P13 and P14, and P15 and P16. All these cDNAs were inserted into EcoRV-digested pBluescript II KS(+) (GeneBank accession number X52327.1) and sequenced. Experimental sequences served to design new primers (P17 to P29, see Supplementary Table S1) to amplify the whole ZYMV genome in three fragments (5', central and 3') by RT-PCR. We applied a nested PCR strategy, in which $1 \mu \mathrm{l}$ of the first reaction was used as a template for the second reaction. These three ZYMV cDNAs were ligated to EcoRV-digested pBluescript II KS(+) using T4 DNA ligase (Thermo Fisher Scientific), and Escherichia coli DH5 $\alpha$ electroporated with the products of ligations.

\section{Construction of ZYMV infectious clones}

The cloned cDNAs corresponding to the 5', central and 3' fragments of the Vera isolate of ZYMV were recovered by digestion with the type-IIS restriction enzyme Eco31I (Thermo 
Fisher Scientific) from the pBluescript II KS(+) derivatives (see above) and assembled (Engler et al., 2009) into the binary vector pG35Z also digested with Eco31I. pG35Z is a binary vector derived from pCLEAN-G181(GenBank accession number EU186083) (Thole et al., 2007) that we constructed as a previous step to assemble the ZYMV full-length clone. The map and sequence of pG35Z is in Supplementary Fig. S6. The resulting plasmid harboring the full cDNA of the Vera isolate of ZYMV (GenBank accession number KX499498) was named pGZYMV. Using PCR with the Phusion high-fidelity DNA polymerase, digestion with Eco31I and ligation with T4 DNA ligase a cDNA corresponding to the coding region of $A$. majus Roseal transcription factor (GenBank accession number DQ275529.1) was inserted between $\mathrm{NIb}$ and CP cistron (positions 8541 and 8542 of KX499498). This cDNA was flanked with sequences coding for amino acids to complement native $\mathrm{NIb} / \mathrm{CP}$ proteolytic site that was split in two (see Supplementary Fig. S1). The resulting plasmid was named pGZYMV-Ros1.

\section{Plant agroinoculation}

A. tumefaciens C58C1 harboring the helper plasmid pCLEAN-S48 (Thole et al., 2007) was electroporated with pG35Z (empty plasmid), pGZYMV or pGZYMV-Ros1. Liquid cultures of transformed A. tumefaciens were grown to optical density $(600 \mathrm{~nm})$ of approximately 1.0. Cells were recovered by centrifugation and resuspended at an optical density $(600 \mathrm{~nm})$ of 0.5 in 10 $\mathrm{mM}$ MES-NaOH, pH 5.6, $10 \mathrm{mM} \mathrm{MgCl}_{2}$ and $150 \mu \mathrm{M}$ acetosyringone. Cultures were induced for $3 \mathrm{~h}$ at $28^{\circ} \mathrm{C}$ and used to agroinoculate zucchini (cultivar MU-CU-16), melon (cultivar Piel de Sapo) or N. benthamiana plants (Bedoya and Daròs, 2010). The inbreeding line MU-CU-16 belongs to the Zucchini morphotype of the ssp. pepo of C. pepo and was provided by the Cucurbits Breeding Group of the Institute for the Conservation and Breeding of Agricultural Biodiversity, Universitat Politècnica de València (Blanca et al., 2011; Esteras et al., 2012). We agroinoculated 3 days old zucchini, approximately one month old melon plants and 4.5 or 5.5 weeks old $N$. benthamiana plants.

\section{Western blot analysis}

Infiltrated tissues of $N$. benthamiana plants ( 5.5 weeks old) were harvested 6 dpi (between 0.45 and $0.89 \mathrm{~g}$ depending on the sample) and ground with a mortar and pestle in the presence of liquid $\mathrm{N}_{2}$. Three volumes of buffer TEW (60 mM Tris-HCl, $\mathrm{pH} 6.8,2 \%$ sodium dodecyl sulfate (SDS), $100 \mathrm{mM}$ dithiothreitol, $10 \% \mathrm{w} / \mathrm{v}$ glycerol and $0.01 \%$ bromophenol blue) were added and the extracts incubated at $95^{\circ} \mathrm{C}$ for $5 \mathrm{~min}$. Extracts were clarified by centrifugation for 15 min and $40 \mu \mathrm{l}$ of the supernatants (equivalent to $13 \mathrm{mg}$ of fresh tissue) separated by 
discontinuous polyacrylamide gel electrophoresis (PAGE) in $12.5 \%$ polyacrylamide gels (5\% polyacrylamide for the stacking gel) containing $0.05 \%$ SDS. Proteins were electroblotted to polyvinylidene fluoride membranes (GE Healthcare), which were blocked for $1 \mathrm{~h}$ in $5 \%$ nonfat milk in buffer WB (10 mM Tris- $\mathrm{HCl}, \mathrm{pH} 7.5,154 \mathrm{mM} \mathrm{NaCl}$ and $0.1 \% \mathrm{w} / \mathrm{v}$ Nonidet P40) and incubated overnight at $4^{\circ} \mathrm{C}$ with an anti ZYMV CP antibody conjugated to alkaline phosphatase (Agdia) at 1:10,000 dilution in 5\% non-fat milk in WB. Membranes were washed three times with WB and alkaline phosphatase detected with CSPD (Roche Life Science). Luminescence was recorded and quantified with a LAS-3000 image analyzer (Fujifilm). This protocol was also used to analyze the accumulation of ZYMV CP in upper non-inoculated leaves of $N$. benthamiana $D C L$ knock-down plants. In this case the whole plant aerial tissues were harvested at $28 \mathrm{dpi}$, frozen, ground and mixed. Aliquots of approximately $1 \mathrm{~g}$ of frozen tissue were sampled for the analysis.

\section{Anthocyanins extraction and quantification}

N. benthamiana wild-type and DCL knock-down (Dadami et al., 2013; Dadami et al., 2013; Katsarou et al., 2016) plants (5 weeks old) were agroinoculated in three leaves with ZYMVRos1, as indicated above. The whole aerial parts of the plants were harvested at $27 \mathrm{dpi}$ and frozen at $-80^{\circ} \mathrm{C}$. Frozen tissues were ground and aliquots of approximately $1 \mathrm{~g}$ were homogenized with 10 volumes of methanol containing $1 \% \mathrm{HCl}$ using a Polytron (Kinematica). Extracts were incubated on ice for $1 \mathrm{~h}$ with occasional vortexing. Extracts were clarified by centrifugation and an aliquot of the supernatant was further diluted 1:5 in $1 \% \mathrm{HCl}$ in methanol (final ratio tissue:extraction solution 1:50). Anthocyanin concentration was quantified by measuring absorbance at $543 \mathrm{~nm}$ with a spectrophotometer (Biowave II, WPA) using a $1 \mathrm{~cm}$ path cuvette.

\section{RT-qPCR analysis of ZYMV RNA}

RNA preparations were purified from $N$. benthamiana tissue samples using the RNeasy Plant Mini Kit (Qiagen) and quantified using a NanoDrop ND-1000 spectrophotomer. cDNAs were synthesized in $20 \mu \mathrm{l}$ reactions including $100 \mathrm{ng}$ of total RNA, $50 \mathrm{U}$ RevertAid reverse transcriptase and 5 pmol of primer P30. Two $\mu 1$ of the products of these reactions were subjected to $20 \mu 1 \mathrm{qPCR}$ amplification reactions by triplicate using the Maxima SYBR Green/ROX qPCR Master Mix (Thermo Scientific) and 6 pmol primers P31 and P32 in a StepOnePlus Real-Time PCR System (Applied Biosystems). The amount of ZYMV RNA molecules present in $100 \mathrm{ng}$ of RNA preparation was calculated from a calibration line obtained in the same condition with 
an RNA standard corresponding to ZYMV 3' genome fragment (from position 8542 to 9592 of KX499498) obtained by in vitro run off transcription and quantified by spectrophotometric analysis. StepOne Software v.2.2.2 (Applied Biosystems) was used to analyze the data.

\section{ACKNOWLEDGEMENTS}

We thank Verónica Aragonés for excellent technical assistance. This work was supported by the Spanish Ministerio de Economía y Competitividad (MINECO) through grants BIO201454269-R and AGL2013-49919-EXP, and by the Greek Ministry for Education and Religious Affairs (Program Aristeia II, 4499, ViroidmiR; ESPA 2007-2013). A.C. was supported by an Individual Fellowship from the European Union's Horizon 2020 research and innovation programme under the Marie Sklodowska-Curie grant agreement No. 655841.

\section{LITERATURE CITED}

Akbergenov, R., Si-Ammour, A., Blevins, T., Amin, I., Kutter, C., Vanderschuren, H., Zhang, P., Gruissem, W., Meins, F., Jr., Hohn, T., and Pooggin, M. M. 2006. Molecular characterization of geminivirus-derived small RNAs in different plant species. Nucleic Acids Res. 34:462-471.

Aliyari, R., and Ding, S. W. 2009. RNA-based viral immunity initiated by the Dicer family of host immune receptors. Immunol. Rev. 227:176-188.

Andika, I. B., Maruyama, K., Sun, L., Kondo, H., Tamada, T., and Suzuki, N. 2015. Differential contributions of plant Dicer-like proteins to antiviral defences against potato virus $\mathrm{X}$ in leaves and roots. Plant J. 81:781-793.

Bally, J., Nakasugi, K., Jia, F., Jung, H., Ho, S. Y., Wong, M., Paul, C. M., Naim, F., Wood, C. C., Crowhurst, R. N., Hellens, R. P., Dale, J. L., and Waterhouse, P. M. 2015. The extremophile Nicotiana benthamiana has traded viral defence for early vigour. Nat. Plants $1: 15165$.

Bedoya, L., Martínez, F., Rubio, L., and Daròs, J. A. 2010. Simultaneous equimolar expression of multiple proteins in plants from a disarmed potyvirus vector. J. Biotechnol. 150:268275. 
Bedoya, L. C., and Daròs, J. A. 2010. Stability of Tobacco etch virus infectious clones in plasmid vectors. Virus Res. 149:234-240.

Bedoya, L. C., Martínez, F., Orzáez, D., and Daròs, J. A. 2012. Visual tracking of plant virus infection and movement using a reporter MYB transcription factor that activates anthocyanin biosynthesis. Plant Physiol. 158:1130-1138.

Blanca, J., Canizares, J., Roig, C., Ziarsolo, P., Nuez, F., and Picó, B. 2011. Transcriptome characterization and high throughput SSRs and SNPs discovery in Cucurbita pepo (Cucurbitaceae). BMC Genomics 12:104.

Butelli, E., Titta, L., Giorgio, M., Mock, H. P., Matros, A., Peterek, S., Schijlen, E. G., Hall, R. D., Bovy, A. G., Luo, J., and Martin, C. 2008. Enrichment of tomato fruit with healthpromoting anthocyanins by expression of select transcription factors. Nat. Biotechnol. 26:1301-1308.

Carbonell, A. 2015. Trading defence for vigour. Nat Plants 1:15174.

Carbonell, A., and Carrington, J. C. 2015. Antiviral roles of plant ARGONAUTES. Current Opin. Plant Biol. 27:111-117.

Coutts, B. A., Kehoe, M. A., Webster, C. G., Wylie, S. J., and Jones, R. A. 2011. Zucchini yellow mosaic virus: biological properties, detection procedures and comparison of coat protein gene sequences. Arch. Virol. 156:2119-2131.

Csorba, T., Kontra, L., and Burgyàn, J. 2015. Viral silencing suppressors: tools forged to finetune host-pathogen coexistence. Virology 479-480:85-103.

Dadami, E., Boutla, A., Vrettos, N., Tzortzakaki, S., Karakasilioti, I., and Kalantidis, K. 2013. DICER-LIKE 4 but not DICER-LIKE 2 may have a positive effect on potato spindle tuber viroid accumulation in Nicotiana benthamiana. Mol. Plant 6:232-234.

Deleris, A., Gallego-Bartolome, J., Bao, J., Kasschau, K. D., Carrington, J. C., and Voinnet, O. 2006. Hierarchical action and inhibition of plant Dicer-like proteins in antiviral defense. Science 313:68-71.

Desbiez, C., and Lecoq, H. 1997. Zucchini yellow mosaic virus. Plant Pathology 46:809-829. 
Dunoyer, P., Schott, G., Himber, C., Meyer, D., Takeda, A., Carrington, J. C., and Voinnet, O. 2010. Small RNA duplexes function as mobile silencing signals between plant cells. Science 328:912-916.

Engler, C., Gruetzner, R., Kandzia, R., and Marillonnet, S. 2009. Golden gate shuffling: a onepot DNA shuffling method based on type IIs restriction enzymes. PLoS One 4:e5553.

Esteras, C., Gómez, P., Monforte, A. J., Blanca, J., Vicente-Dólera, N., Roig, C., Nuez, F., and Picó, B. 2012. High-throughput SNP genotyping in Cucurbita pepo for map construction and quantitative trait loci mapping. BMC Genomics 13:80.

Feder, A., Burger, J., Gao, S., Lewinsohn, E., Katzir, N., Schaffer, A. A., Meir, A., DavidovichRikanati, R., Portnoy, V., Gal-On, A., Fei, Z., Kashi, Y., and Tadmor, Y. 2015. A kelch domain-containing F-box coding gene negatively regulates flavonoid accumulation in muskmelon. Plant Physiol. 169:1714-1726.

Garcia-Ruiz, H., Takeda, A., Chapman, E. J., Sullivan, C. M., Fahlgren, N., Brempelis, K. J., and Carrington, J. C. 2010. Arabidopsis RNA-dependent RNA polymerases and Dicerlike proteins in antiviral defense and small interfering RNA biogenesis during Turnip mosaic virus infection. Plant Cell 22:481-496.

Hamilton, A. J., and Baulcombe, D. C. 1999. A species of small antisense RNA in posttranscriptional gene silencing in plants. Science 286:950-952.

Imperato, F. 1980. Five plants of the family Cucurbitaceae with flavonoid patterns of pollens different from those of corresponding stigmas. Experientia 36:1136-1137.

Katsarou, K., Mavrothalassiti, E., Dermauw, W., Van Leeuwen, T., and Kalantidis, K. 2016. Combined activity of DCL2 and DCL3 is crucial in the defense against Potato spindle tuber viroid. PLoS Pathog. 12:e1005936.

Krauze-Baranowska, M., and Cisowski, W. 2001. Flavonoids from some species of the genus Cucumis. Biochem. Syst. Ecol. 29:321-324.

Lecoq, H., and Desbiez, C. 2012. Viruses of cucurbit crops in the Mediterranean region: an ever-changing picture. Adv. Virus Res. 84:67-126.

Lesemann, D. E., Makkouk, K. M., Koenig, R., and Natafji Samman, E. 1983. Natural infection of cucumbers by zucchini yellow mosaic virus in Lebanon. Phytopathologische Zeitschrift 108:304-313. 
Lin, S. S., Hou, R. F., and Yeh, S. D. 2001. Complete genome sequence and genetic organization of a Taiwan isolate of Zucchini yellow mosaic virus. Bot. Bul. Acad. Sin. 42:243-250.

Lisa, V., Boccardo, G., D'Agostino, G., Dellavalle, G., and D'Aquilio, M. 1981. Characterization of a potyvirus that causes zucchini yellow mosaic. Phytopathology 71:667-672.

Majer, E., Daròs, J. A., and Zwart, M. P. 2013. Stability and fitness impact of the visually discernible Rosea1 marker in the Tobacco etch virus genome. Viruses 5:2153-2168.

Mermigka, G., Verret, F., and Kalantidis, K. 2016. RNA silencing movement in plants. J. Integr. Plant Biol. 58:328-342.

Nakasugi, K., Crowhurst, R. N., Bally, J., Wood, C. C., Hellens, R. P., and Waterhouse, P. M. 2013. De novo transcriptome sequence assembly and analysis of RNA silencing genes of Nicotiana benthamiana. PLoS One 8:e59534.

Revers, F., and García, J. A. 2015. Molecular biology of potyviruses. Adv. Virus Res. 92:101199.

Su, X., Xu, J., Rhodes, D., Shen, Y., Song, W., Katz, B., Tomich, J., and Wang, W. 2016. Identification and quantification of anthocyanins in transgenic purple tomato. Food Chem. 202:184-188.

Tadmor, Y., Burger, J., Yaakov, I., Feder, A., Libhaber, S. E., Portnoy, V., Meir, A., Tzuri, G., Sa'ar, U., Rogachev, I., Aharoni, A., Abeliovich, H., Schaffer, A. A., Lewinsohn, E., and Katzir, N. 2010. Genetics of flavonoid, carotenoid, and chlorophyll pigments in melon fruit rinds. J. Agric. Food Chem. 58:10722-10728.

Thole, V., Worland, B., Snape, J. W., and Vain, P. 2007. The pCLEAN dual binary vector system for Agrobacterium-mediated plant transformation. Plant Physiol. 145:1211-1219.

Tilsner, J., and Oparka, K. J. 2010. Tracking the green invaders: advances in imaging virus infection in plants. Biochem. J. 430:21-37.

Wang, H. L., Gonsalves, D., Provvidenti, R., and Zitter, T. A. 1992. Comparative biological and serological properties of four strains of zucchini yellow mosaic virus. Plant Dis. $76: 530-535$. 
Wang, X. B., Wu, Q., Ito, T., Cillo, F., Li, W. X., Chen, X., Yu, J. L., and Ding, S. W. 2010. RNAi-mediated viral immunity requires amplification of virus-derived siRNAs in Arabidopsis thaliana. Proc. Natl. Acad. Sci. USA 107:484-489.

Wu, H. W., Lin, S. S., Chen, K. C., Yeh, S. D., and Chua, N. H. 2010. Discriminating mutations of HC-Pro of Zucchini yellow mosaic virus with differential effects on small RNA pathways involved in viral pathogenicity and symptom development. Mol. Plant-Microbe Interact. 23:17-28.

Zhang, C., Wu, Z., Li, Y., and Wu, J. 2015. Biogenesis, function, and applications of virusderived small RNAs in plants. Front. Microbiol. 6:1237.

Zhang, H., Wang, L., Hunter, D., Voogd, C., Joyce, N., and Davies, K. 2013. A Narcissus mosaic viral vector system for protein expression and flavonoid production. Plant Methods 9:28.

Zhang, Y., Butelli, E., and Martin, C. 2014. Engineering anthocyanin biosynthesis in plants. Current Opin. Plant Biol. 19:81-90.

Ziebell, H., and Carr, J. P. 2009. Effects of dicer-like endoribonucleases 2 and 4 on infection of Arabidopsis thaliana by cucumber mosaic virus and a mutant virus lacking the $2 \mathrm{~b}$ counter-defence protein gene. J. Gen. Virol. 90:2288-2292. 


\section{SUPPORTING INFORMATION}

Supplementary Fig. S1. Sequence of the cDNA that corresponded to the coding region of $A$. majus Rosea1 (GenBank accession number DQ275529.1) that was inserted between cistrons $\mathrm{NIb}$ and CP (between positions 8541 and 8542) of the Vera isolated of ZYMV (GenBank accession number KX499498) to obtain recombinant clone ZYMV-Ros1. The cDNA of Rosea1 was flanked at 5' and 3' by extra nucleotides (underlined) which encode peptides that complement the two parts of the split NIb/CP proteolytic site.

>Roseal CDNA from $A$. majus with $5^{\prime}$ and $3^{\prime}$ extra sequences

TCTGGCACAATGGAAAAGAATTGTCGTGGAGTGAGAAAAGGTACTTGGACCAAAGAAGAAGACACTCTCTTGAGG CAATGTATAGAAGAGTATGGTGAAGGGAAATGGCATCAAGTTCCACACAGAGCAGGGTTGAACCGGTGTAGGAAG AGTTGCAGGCTGAGGTGGTTGAATTATCTGAGGCCAAATATCAAAAGAGGTCGGTTTTCGAGAGATGAAGTGGAC СTAATTGTGAGGCTTCATAAGCTGTTGGGTAACAAATGGTCGCTGATTGCTGGTAGAATTCCTGGAAGGACAGCT AATGACGTGAAGAACTTTTGGAATACTCATGTGGGGAAGAATTTAGGCGAGGATGGAGAACGATGCCGGAAAAAT GTTATGAACACAAAAACCATTAAGCTGACTAATATCGTAAGACCCCGAGCTCGGACCTTCACCGGATTGCACGTT ACTTGGCCGAGAGAAGTCGGAAAAACCGATGAATTTTCAAATGTCCGGTTAACAACTGATGAGATTCCAGATTGT GAGAAGCAAACGCAATTTTACAATGATGTTGCGTCGCCACAAGATGAAGTTGAAGACTGCATTCAGTGGTGGAGT AAGTTGCTAGAAACAACGGAGGATGGGGAATTAGGAAACCTATTCGAGGAGGCCCAACAAATTGGAAATCAGGGA GATACTGTGATGCTTCAA

Supplementary Fig. S2. Zucchini plants agroinoculated with the empty binary plasmid, with ZYMV or with ZYMV-Ros1. Pictures show three independent plants inoculated with each $A$. tumefaciens culture and selected leaves from each plant to better appreciate symptoms. All the pictures were taken on 21 dpi. Close-ups of some of these pictures were used to create Fig. 1.
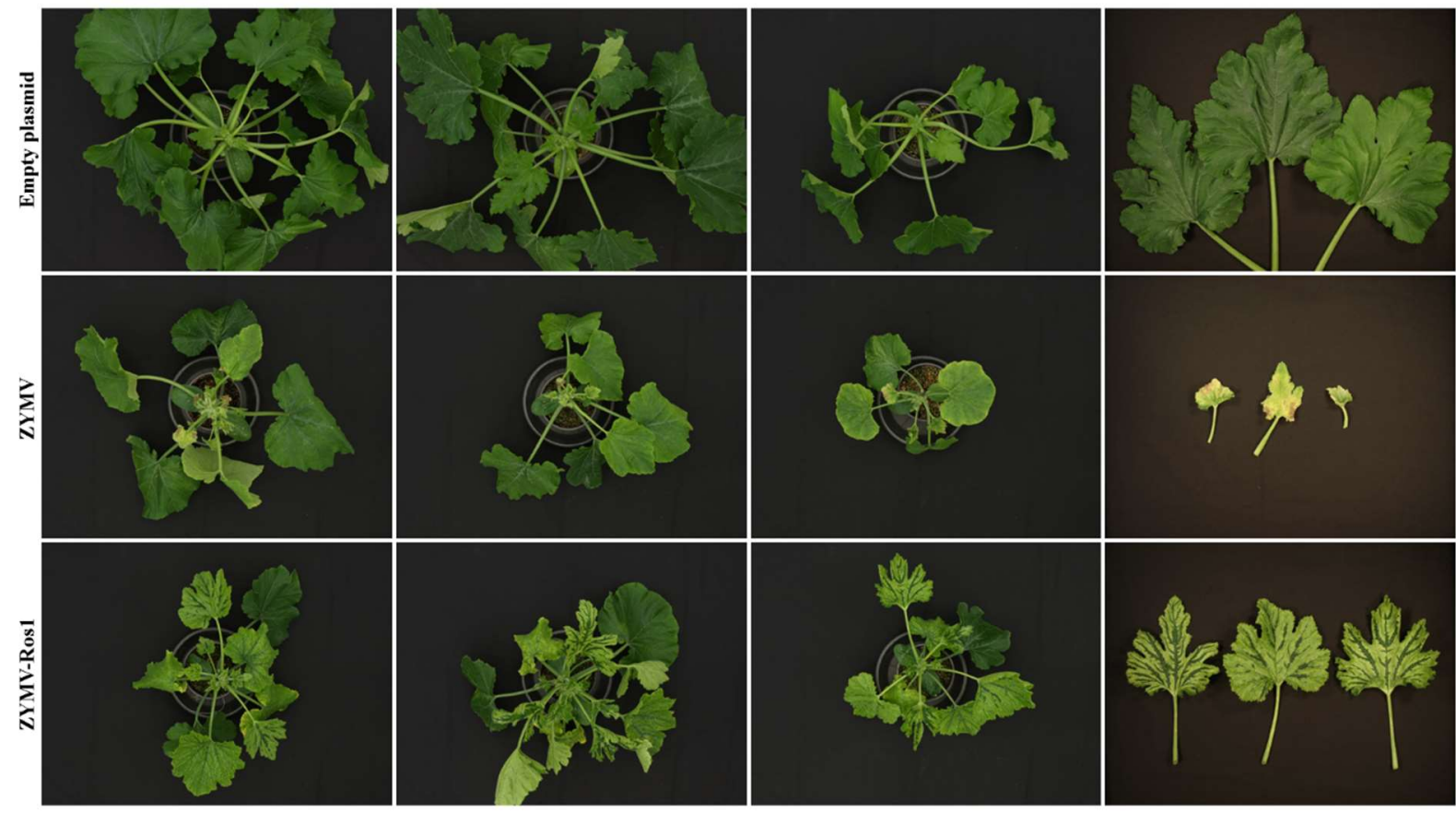
Supplementary Fig. S3. Pictures of melon plants agroinoculated with ZYMV-Ros1 (17 dpi).
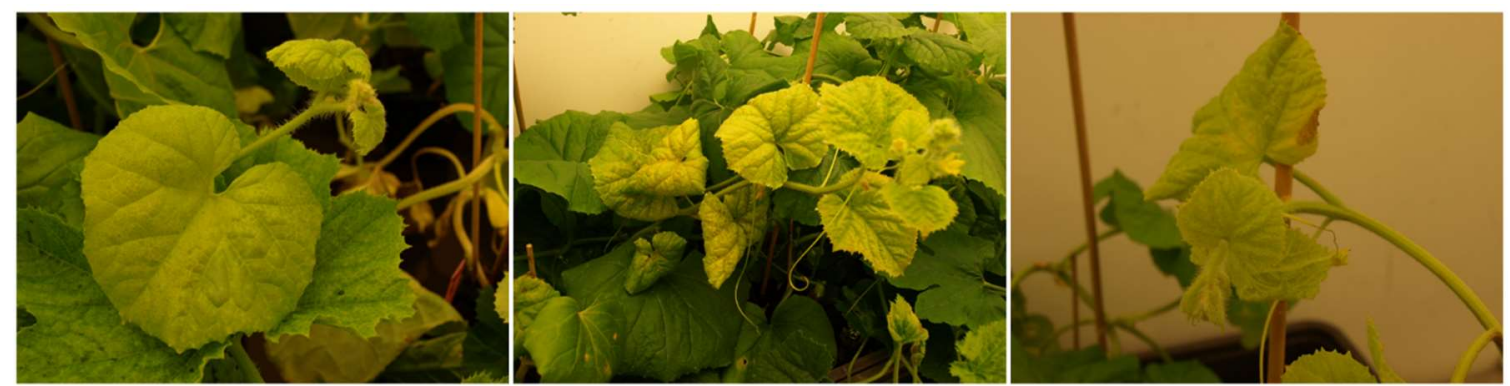

Supplementary Fig. S4. ZYMV-Ros1 very inefficiently moves long-distance in $N$. benthamiana. A, Sets of three N. benthamiana leaves agroinoculated with the empty plasmid, ZYMV or ZYMV-Ros1. Pictures were taken on 7 dpi. B, Groups of three $N$. benthamiana plants agroinoculated with the empty plasmid, ZYMV or ZYMV-Ros1 photographed at $21 \mathrm{dpi}$.
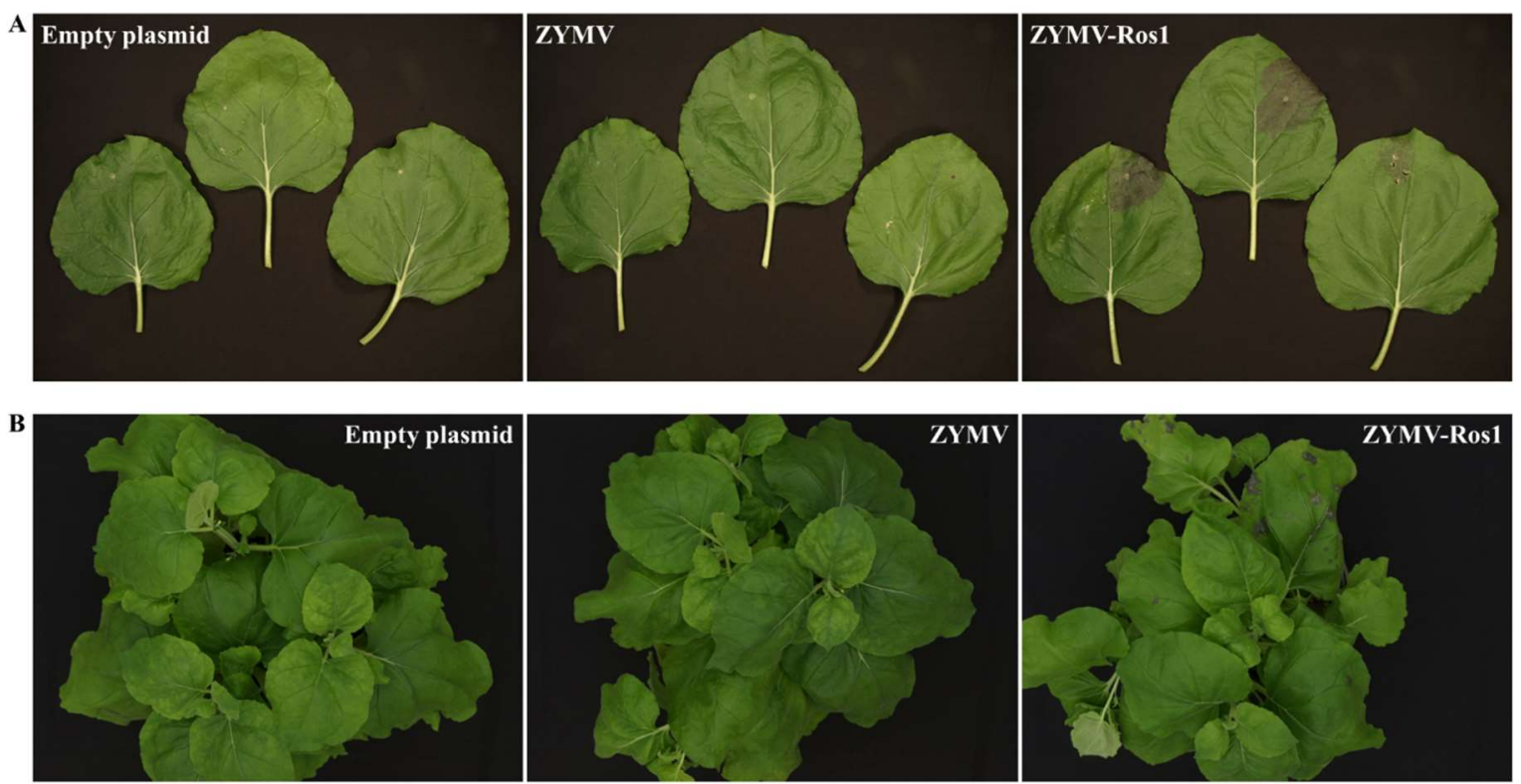

Supplementary Fig. S5. ZYMV-Ros1 more efficiently moves long-distance more efficiently in the N. benthamiana lines in which gene DCL4 is down-regulated. A, Pictures taken at 27 dpi of the sets of the three $N$. benthamiana plants that correspond to wild-type and the DCL knockdown lines, as indicated, agroinoculated with ZYMV-Ros1. Close-ups of some of these pictures were used to create Fig. 4. B, Pictures taken at 27 dpi of selected leaves from the above plants to better appreciate the different patterns of anthocyanin accumulation. 

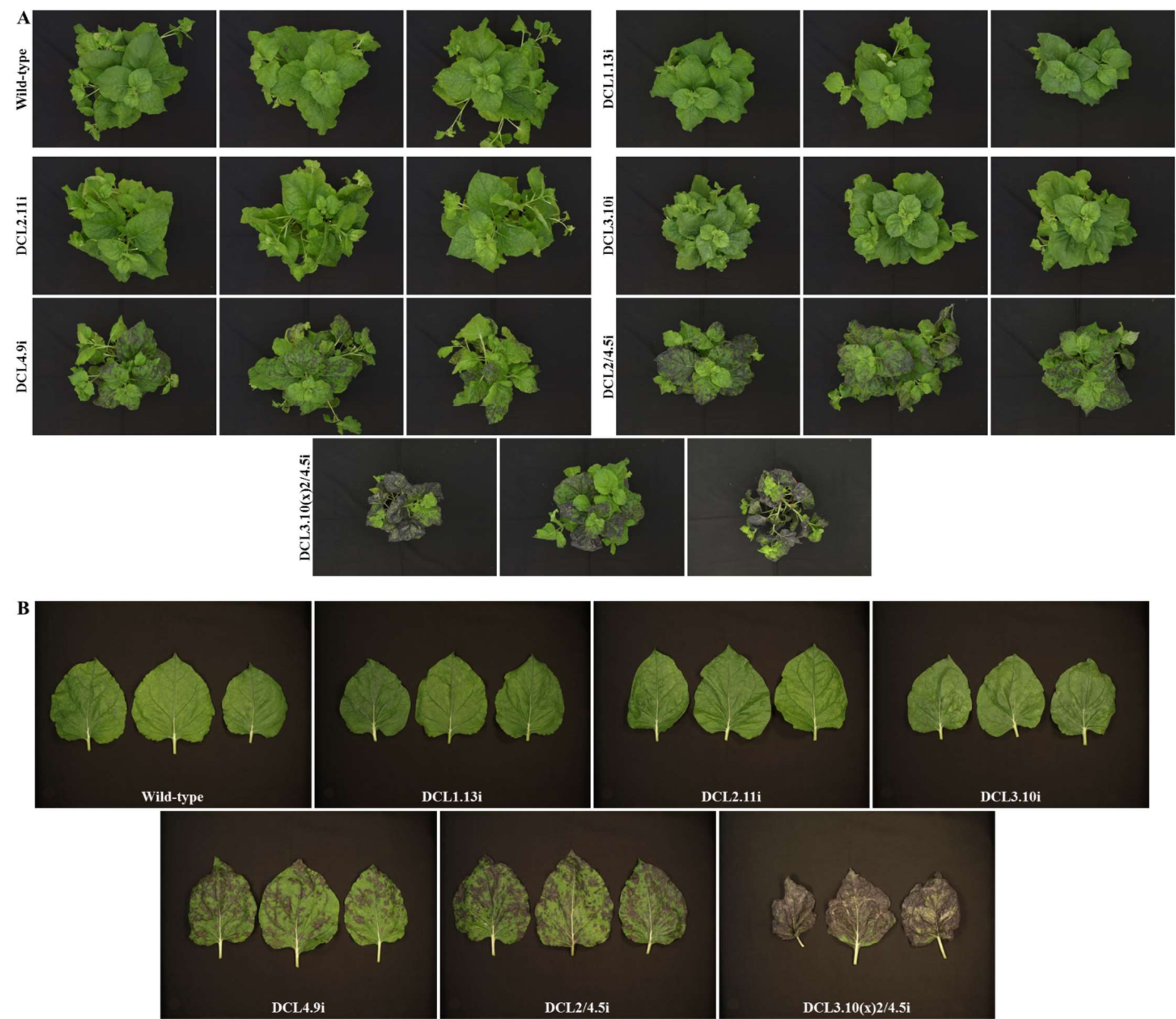

Supplementary Fig. S6. Map and sequence of binary vector pG35Z. The plasmid contains a cloning site that consists in two inverted BsaI cleavage sites separated by a LacZ' ( $\beta$ galactosidase $\alpha$ peptide from $E$. coli) selection marker. The two BsaI recognition sites are on a green background with the corresponding cleavage sites underlined. The LacZ' cassette is in italics. The CaMV 35S promoter (P35S in the map) is in red with the +1 nucleotide on a yellow background. The CaMV 35S transcription terminator (T35S in the map) is in fuchsia with the polyadenylation site underlined. The T-DNA right border (RB in the map) is on a yellow background with the overdrive sequence underlined. The pUC replication origin for E. coli is on a gray background. Kanamycin resistance marker (NPTI in the map) is on a dark gray 
background. This marker contains a silent mutation (in red) to eliminate an undesired BsmBI restriction site. The pSa replication origin for A. tumefaciens is in blue on a gray background. A double T-DNA left border $(2 \times \mathrm{LB}$ in the map) is on a red background.

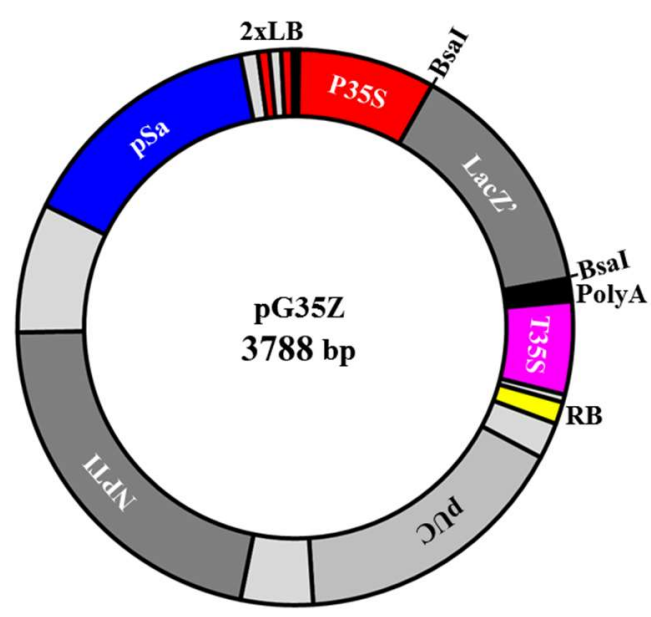

$>$ pG35z

GCGGCCGCGATTCCATTGCCCAGCTATCTGTCACTTTATTGTGAAGATAGTGGAAAAGGAAGGTGGCTCCTACAA ATGCCATCATTGCGATAAAGGAAAGGCCATCGTTGAAGATGCCTCTGCCGACAGTGGTCCCAAAGATGGACCCCC ACCCACGAGGAGCATCGTGGAAAAAGAAGACGTTCCAACCACGTCTTCAAAGCAAGTGGATTGATGTGATATCTC CACTGACGTAAGGGATGACGCACAATCCCACTATCCTTCGCAAGACCCTTCCTCTATATAAGGAAGTTCATTTCA TTTGGAGAGGGGAGACCATAAGCGG CGCGTCCCATTCGCCATTCAGGCTGCGCAACTGTTGGGAAGGGCGATCGG TGCGGGCCTCTTCGCTATTACGCCAGCTGGCGAAAGGGGGATGTGCTGCAAGGCGATTAAGTTGGGTAACGCCAG GGTTTTCCCAGTCACGACGTTGTAAAACGACGGCCAGTGAGCGCGCGTAATACGACTCACTATAGGGCGAATTGG AGCTCCACCGCGGTGGCGGCCGCTCTAGAACTAGTGGATCCCCCGGGCTGCAGGAATTCGATATCAAGCTTATCG ATACCGTCGACCTCGAGGGGGGGCCCGGTACCCAGCTTTTGTTCCCTTTAGTGAGGGTTAATTGCGCGCTTGGCG TAATCATGGTCATAGCTGTTTCCTGTGTGAAATTGTTATCCGCTCACAATTCCACACAACATACGAGCCGGGAGC ATAAAGTGTAAAGCCTGGGGTGCCTAATGAGTGAGCTAACTCACATTAATTGCGTTGCGCTCACTGCCCGCTTTC GGCGAATAGGTCTCGAAAAAAAAAAAAAAAAAAAAAAAAAAAAAAAAAAAAAAAAAAAAAAAAAACGC TGAAATC ACCAGTCTCTCTCTACAAATCTATCTCTCTCTATTTTCTCCATAAATAATGTGTGAGTAGTTTCCCGATAAGGGA AATTAGGGTTCTTATAGGGTTTCGCTCATGTGTTGAGCATATAAGAAACCCTTAGTATGTATTTGTATTTGTAAA ATACTTCTATCAATAAAATTTCTAATTCCTAAAACCAAAATCCAGGGGCCCTCGACGTTCCTTGACAGGATATAT TGGCGGGTAAACTAAGTCGCTGTATGTGTTTGTTTGAGATCCTCTAGGGCATGCAAGCTGATCTGGATCTCATGT GAGCAAAAGGCCAGCAAAAGGCCAGGAACCGTAAAAAGGCCGCGTTGCTGGCGTTTTTCCATAGGCTCCGCCCCC CTGACGAGCATCACAAAAATCGACGCTCAAGTCAGAGGTGGCGAAACCCGACAGGACTATAAAGATACCAGGCGT TTCCCCCTGGAAGCTCCCTCGTGCGCTCTCCTGTTCCGACCCTGCCGCTTACCGGATACCTGTCCGCCTTTCTCC CTTCGGGAAGCGTGGCGCTTTCTCATAGCTCACGCTGTAGGTATCTCAGTTCGGTGTAGGTCGTTCGCTCCAAGC TGGGCTGTGTGCACGAACCCCCCGTTCAGCCCGACCGCTGCGCCTTATCCGGTAACTATCGTCTTGAGTCCAACC CGGTAAGACACGACTTATCGCCACTGGCAGCAGCCACTGGTAACAGGATTAGCAGAGCGAGGTATGTAGGCGGTG CTACAGAGTTCTTGAAGTGGTGGCCTAACTACGGCTACACTAGAAGAACAGTATTTGGTATCTGCGCTCTGCTGA AGCCAGTTACCTTCGGAAGAAGAGTTGGTAGCTCTTGATCCGGCAAACAAACCACCGCTGGTAGCGGTGGTTTTT TTGTTTGCAAGCAGCAGATTACGCGCAGAAAAAAAGGATCTCAAGAAGATCCTTTGATCTTTTCTACGGGGTCTG ACGCTCAGTGGAACGAAAACTCACGTTAAGGGATTTTGGTCATGAGATTATCAAAAAGGATCTTCACCTAGATCC TTTTAAATTAAAAATGAAGTTTTAAATCAATCTAAAGTATATATGTGTAACATTGGTCTAGTGATTAGAAAAACT CATCGAGCATCAAATGAAACTGCAATTTATTCATATCAGGATTATCAATACCATATTTTTGAAAAAGCCGTTTCT GTAATGAAGGAGAAAACTCACCGAGGCAGTTCCATAGGATGGCAAGATCCTGGTATCGGTCTGCGATTCCGACTC GTCCAACATCAATACAACCTATTAATTTCCCCTCGTCAAAAATAAGGTTATCAAGTGAGAAATCACCATGAGTGA CGACTGAATCCGGTGAGAAT GGCAAAAGTTTATGCATTTCTTTCCAGACTTGTTCAACAGGCCAGCCATTACGCT CGTCATCAAAATCACTCGCATCAACCAAACCGTTATTCATTCGTGATTGCGCCTGAGCAAGACGAAATACGCGAT CGCTGTTAAAAGGACAATTACAAACAGGAATCGAATGCAACCGGCGCAGGAACACTGCCAGCGCATCAACAATAT TTTCACCTGAATCAGGATATTCTTCTAATACCTGGAATGCTGTTTTCCCTGGGATCGCAGTGGTGAGTAACCATG 


\section{Capítulo I}

CATCATCAGGAGTACGGATAAAATGCTTGATGGTCGGAAGAGGCATAAATTCCGTCAGCCAGTTTAGTCTGACCA TCTCATCTGTAACAACATTGGCAACGCTACCTTTGCCATGTTTCAGAAACAACTCTGGCGCATCGGGCTTCCCAT ACAATCGGTAGATTGTCGCACCTGATTGCCCGACATTATCGCGAGCCCATTTATACCCATATAAATCAGCATCCA TGTTGGAATTTAATCGCGGCCTTGAGCAAGACGTTTCCCGTTGAATATGGCTCATAACACCCCTTGTATTACTGT TTATGTAAGCAGACAGTTTTATTGTTCATGATGATATATTTTTATCTTGTGCAATGTAACATCAGAGATTTTGAG ACACAACGTGGCTTTGTTGAATAAATCGAACTTTTGCTGAGTTGAAGGATCAGATCACGCATCTTCCCGACAACG CAGACCGTTCCGTGGCAAAGCAAAAGTTCAAAATCACCAACTGGTCCACCTACAACAAAGCTCTCATCAACCGTG GCTCCCTCACTTTCTGGCTGGATGATGGGGCGATTCAGGCGATCCCCATCCAACAGCCCGCCGTCGAGCGGGCTT TTTTATCCCCGGAAGCCTGTGGATAGAGGGTAGTTATCCACGTGAAACCGCTAATGCCCCGCAAAGCCTTGATTC ACGGGGCTTTCCGGCCCGCTCCAAAAACTATCCACGTGAAATCGCTAATCAGGGTACGTGAAATCGCTAATCGGA GTACGTGAAATCGCTAATAAGGTCACGTGAAATCGCTAATCAAAAAGGCACGTGAGAACGCTAATAGCCCTTTCA GATCAACAGCTTGCAAACACCCCTCGCTCCGGCAAGTAGTTACAGCAAGTAGTATGTTCAATTAGCTTTTCAATT ATGAATATATATATCAATTATTGGTCGCCCTTGGCTTGTGGACAATGCGCTACGCGCACCGGCTCCGCCCGTGGA CAACCGCAAGCGGTTGCCCACCGTCGAGCGCCTTTGCCCACAACCCGGCGGCCGGCCGCAACAGATCGTTTTATA AATTTTTTTTTTGAAAAAGAAAAAGCCCGAAAGGCGGCAACCTCTCGGGCTTCTGGATTTCCGATCCCCGGAAT TAGATCCGTTTAAACTACGTAAGATCGATCTTGGCAGGATATATTGTGGTGTAAACGTTCCTGCGGCGGTCGAGA TGGATCTTGGCAGGATATATTGTGGTGTAAACGTTCCT 
Supplementary Table S1. The oligonucleotides used to amplify ZYMV cDNAs by RT-PCR or 5' and 3' RACE.

\begin{tabular}{|c|c|c|c|}
\hline $\begin{array}{c}\text { Primer } \\
\text { name }\end{array}$ & Sequence $^{1}$ & $\begin{array}{l}\text { Type of } \\
\text { reaction }\end{array}$ & $\begin{array}{l}\text { Purpose of } \\
\text { reaction }\end{array}$ \\
\hline P1 & TGTTAATATCAAAGTCAATTGTGAG & RT & \multirow{3}{*}{$\begin{array}{l}\text { Amplification } \\
\text { internal cDNA }\end{array}$} \\
\hline $\mathrm{P} 2$ & GTTGCTCTGGCTGAAGTTCTTGTGG & \multirow{2}{*}{ PCR } & \\
\hline P3 & TATCGTCCTCCAAGCTCTCAATATC & & \\
\hline $\mathrm{P} 4$ & GCGATTTTACTAGGTTGCCATAGCC & RT & \multirow{3}{*}{$\begin{array}{l}\text { Amplification } \\
\text { internal cDNA }\end{array}$} \\
\hline P5 & GCATTTATATGGTGTGGAGCCTGAG & \multirow{2}{*}{ PCR } & \\
\hline P6 & GTTGAGTCCATGTGAGATCGTCAAG & & \\
\hline P7 & $\begin{array}{l}\text { CCAGTGAGCAGAGTGACGAGGACTCGAG } \\
\text { CTCAAGCTTTTTTTTTTTTTTTTTVN }{ }^{2}\end{array}$ & RT & \multirow{5}{*}{ 3' RACE } \\
\hline P8 & TTGTTTGGCCTTGATGGAAATG & & \\
\hline P9 & CCAGTGAGCAGAGTGACG & & \\
\hline P10 & GCCACCACTAGCGAAGACACTG & \multirow{2}{*}{$2^{\text {nd }}$ nested PCR } & \\
\hline P11 & GAGGACTCGAGCTCAAGC & & \\
\hline P12 & TGAAGAAGTTGTTCAGAATGTC & RT & \multirow{5}{*}{ 5' RACE } \\
\hline P13 & $\begin{array}{l}\text { GAGTGACGAGGACTCGAGCTCAAGCAAA } \\
\text { AAAAAAAAAAAAAAABN }\end{array}$ & $1^{\text {st }} \mathrm{PCR}$ & \\
\hline P14 & GCTTTTGTTTGATTGCATCAAC & & \\
\hline P15 & GAGTGACGAGGACTCGAGCTCAAGC & \multirow{2}{*}{$2^{\text {nd }}$ nested PCR } & \\
\hline P16 & CTTGGACTCATGCCTGTAGTATG & & \\
\hline P17 & CACAGTATTAGACATTTGTAACACC & RT & \multirow{5}{*}{$\begin{array}{l}\text { Amplification 5, } \\
\text { fragment ZYMV } \\
\text { genome }\end{array}$} \\
\hline P18 & AAATTAAAACAAATCACAAAG & & \\
\hline P19 & AAGAGAATACCAAACACACGTTCAC & & \\
\hline $\mathrm{P} 20$ & $\begin{array}{l}\text { GGCGGGTCTCGGAGGAAATTAAAACAAA } \\
\text { TCACAAAGACTACAG }^{4}\end{array}$ & \multirow{2}{*}{$2^{\text {nd }}$ nested PCR } & \\
\hline $\mathrm{P} 21$ & $\begin{array}{l}\text { CCGCGGTCTCCGGTATATAATGTCGCTGT } \\
\text { AACACCG }\end{array}$ & & \\
\hline $\mathrm{P} 22$ & CACCATGCCAAGACCTGACTAGAAG & RT & \multirow{3}{*}{$\begin{array}{l}\text { Amplification } \\
\text { central fragment } \\
\text { ZYMV genome }\end{array}$} \\
\hline $\mathrm{P} 23$ & GATTTTTGCGCGGTGTTACAGCGAC & \multirow{2}{*}{$1^{\text {st }} \mathrm{PCR}$} & \\
\hline P24 & TGTACCATTGTTTTTCCTGAAGAGG & & \\
\hline
\end{tabular}




\begin{tabular}{|c|c|c|c|}
\hline $\mathrm{P} 25$ & $\begin{array}{l}\text { GGCGGGTCTCGTACCTTGTGAACGTGTGT } \\
\text { TTGG }\end{array}$ & \multirow{2}{*}{$2^{\text {nd }}$ nested PCR } & \\
\hline $\mathrm{P} 26$ & $\begin{array}{l}\text { CCGCGGTCTCCTGCCCATTAGTAATGATT } \\
\text { ATCGGCC }\end{array}$ & & \\
\hline $\mathrm{P7}$ & See above & RT & \multirow{5}{*}{$\begin{array}{l}\text { Amplification 3' } \\
\text { fragment ZYMV } \\
\text { genome }\end{array}$} \\
\hline $\mathrm{P} 27$ & $\begin{array}{l}\text { GGCGGGTCTCGGGCACCTCTTCAGGAAA } \\
\text { AACAATGG }\end{array}$ & \multirow[t]{2}{*}{$1^{\text {st }} \mathrm{PCR}$} & \\
\hline $\mathrm{P} 28$ & TTTTTTAGGCTTGCAAACGGAG & & \\
\hline $\mathrm{P} 27$ & See above & \multirow{2}{*}{$\begin{array}{l}2^{\text {nd }} \text { heminested } \\
\text { PCR }\end{array}$} & \\
\hline P29 & $\begin{array}{l}\text { CCGCGGTCTCCTTTTAGGCTTGCAAACGG } \\
\text { AGTCTAATC }\end{array}$ & & \\
\hline P30 & AGGCTTGCAAACGGAGTCTAA & $\overline{\mathrm{RT}}$ & \multirow{3}{*}{$\begin{array}{l}\text { Quantification } \\
\text { ZYMV RNA }\end{array}$} \\
\hline P31 & CTGCCACGCGTGAAAGG & \multirow{2}{*}{ qPCR } & \\
\hline P32 & CCGGTTTATATTCCAGCAAATGA & & \\
\hline
\end{tabular}

${ }^{1}$ From 5' to 3' end.

${ }^{2} \mathrm{~V}$ is $\mathrm{A}, \mathrm{C}$ or $\mathrm{G}$ and $\mathrm{N}$ is $\mathrm{A}, \mathrm{C}, \mathrm{G}$ or $\mathrm{T}$.

${ }^{3} \mathrm{~B}$ is $\mathrm{C}, \mathrm{G}$ or $\mathrm{T}$.

${ }^{4} \mathrm{Eco} 31 \mathrm{I}$ recognition and cleavage sites are in italics and underlined, respectively. 
Supplementary Table S2. Accumulation of ZYMV CP in agroinoculated tissues of the wildtype $N$. benthamiana plants and lines down-regulated in different $D C L$ genes. Quantitative data were obtained by a Western blot analysis with a specific polyclonal antibody conjugated to alkaline phosphatase and luminescent detection (see Supplementary Fig. S5).

\begin{tabular}{|c|c|c|c|c|c|}
\hline \multirow[b]{2}{*}{ Plants } & \multicolumn{3}{|c|}{$\begin{array}{c}\text { ZYMV CP amount } \\
\text { (luminescence arbitrary units) }^{1}\end{array}$} & \multirow[b]{2}{*}{ Average } & \multirow{2}{*}{$\begin{array}{c}\text { Standard } \\
\text { error } \\
\text { median }\end{array}$} \\
\hline & Replicate 1 & Replicate 2 & Replicate 3 & & \\
\hline Wild-type ${ }^{2}$ & 48142 & 87773 & 39815 & 58576.7 & 14794.8 \\
\hline Wild-type & 4036630 & 6094050 & 4831809 & 4987496.3 & 599005.6 \\
\hline DCL1.13i & 3404372 & 5033826 & 4252287 & 4230161.7 & 470512.9 \\
\hline DCL2.11i & 3871764 & 4865003 & 7172089 & 5302952.0 & 977562.6 \\
\hline DCL3.10i & 2777713 & 2192118 & 4054795 & 3008208.7 & 549920.5 \\
\hline DCL4.9i & 3960995 & 5262727 & 5941922 & 5055214.7 & 581181.0 \\
\hline DCL2/4.5i & 5371757 & 6579362 & 5882827 & 5944648.7 & 349973.3 \\
\hline $\begin{array}{l}\text { DCL3.10 } \\
\text { (x) } 2 / 4.5 \mathrm{i}\end{array}$ & 10936518 & 6679362 & 8532089 & 8715989.7 & 1232370.2 \\
\hline
\end{tabular}

${ }^{1}$ Background luminescences of 3443482, 3450638 and 3467911 were subtracted from the measurements of replicates 1, 2 and 3, respectively.

${ }^{2}$ Non-agroinoculated control. 
Supplementary Table S3. Anthocyanin accumulation in systemic tissues of $N$. benthamiana plants agroinoculated with ZYMV-Ros1. Plants corresponded to wild-type and the lines downregulated in different $D C L$ genes.

\begin{tabular}{|c|c|c|c|c|c|}
\hline \multirow[b]{2}{*}{ Plants } & \multicolumn{3}{|c|}{$\begin{array}{l}\text { Anthocyanin accumulation } \\
\text { (absorbance } 543 \mathrm{~nm})^{1}\end{array}$} & \multirow[b]{2}{*}{ Average } & \multirow{2}{*}{$\begin{array}{l}\text { Standard } \\
\text { error } \\
\text { median }\end{array}$} \\
\hline & Plant 1 & Plant 2 & Plant 3 & & \\
\hline Wild-type & 0.023 & 0.013 & 0.020 & 0.019 & 0.003 \\
\hline DCL1.13i & 0.002 & 0.005 & 0.028 & 0.012 & 0.008 \\
\hline DCL2.11i & 0.010 & 0.008 & -0.014 & 0.001 & 0.008 \\
\hline DCL3.10i & 0.092 & -0.017 & 0.019 & 0.031 & 0.032 \\
\hline DCL4.9i & 0.296 & 0.298 & 0.293 & 0.296 & 0.001 \\
\hline DCL2/4.5i & 0.537 & 0.531 & 0.552 & 0.540 & 0.006 \\
\hline $\begin{array}{l}\text { DCL3.10 } \\
\text { (x) } 2 / 4.5 \mathrm{i}\end{array}$ & 0.551 & 0.902 & 1.143 & 0.865 & 0.172 \\
\hline
\end{tabular}

${ }^{1} \mathrm{~A}$ background absorbance of 0.095 (average measure for three wild-type non-inoculated control plants) was subtracted 
CAPÍTULO II 



\title{
A Recombinant Potato virus $Y$ Infectious Clone Tagged with the Rosea1 Visual Marker (PVY-Ros1) Facilitates the Analysis of Viral Infectivity and Allows the Production of Large Amounts of Anthocyanins in Plants
}

\author{
Teresa Cordero ${ }^{1}$, Mohamed A. Mohamed ${ }^{1}$, Juan-José López-Moya ${ }^{2}$, and José-Antonio Daròs ${ }^{1 *}$ \\ ${ }^{1}$ Instituto de Biología Molecular y Celular de Plantas (Consejo Superior de Investigaciones \\ Cientificas-Universidad Politécnica de Valencia), 46022 Valencia, Spain, ${ }^{2}$ Centre for Research in \\ Agricultural Genomics (CRAG) CSIC-IRTA-UAB-UB, Campus UAB Bellaterra, 08193 Barcelona, \\ Spain
}

*Correspondence: José-Antonio Daròs, jadaros@ibmcp.upv.es 


\section{ABSTRACT}

Potato virus $Y$ (PVY) is a major threat to the cultivation of potato and other solanaceous plants. By inserting a cDNA coding for the Antirrhinum majus Rosea1 transcription factor into a PVY infectious clone, we created a biotechnological tool (PVY-Ros1) that allows infection by this relevant plant virus to be tracked by the naked eye with no need for complex instrumentation. Rosea1 is an MYB-type transcription factor whose expression activates the biosynthesis of anthocyanin pigments in a dose-specific and cell-autonomous manner. Our experiments showed that the mechanical inoculation of solanaceous plants with PVY-Ros1 induced the formation of red infection foci in inoculated tissue and solid dark red pigmentation in systemically infected tissue, which allows disease progression to be easily monitored. By using silver nanoparticles, a nanomaterial with exciting antimicrobial properties, we proved the benefits of PVY-Ros1 to analyze novel antiviral treatments in plants. PVY-Ros1 was also helpful for visually monitoring the virus transmission process by an aphid vector. Most importantly, the anthocyanin analysis of infected tobacco tissues demonstrated that PVY-Ros1 is an excellent biotechnological tool for molecular farming because it induces the accumulation of larger amounts of anthocyanins, antioxidant compounds of nutritional, pharmaceutical and industrial interest, than those that naturally accumulate in some fruits and vegetables well known for their high anthocyanin content. Hence these results support the notion that the virus-mediated expression of regulatory factors and enzymes in plants facilitates easy quick plant metabolism engineering.

\section{INTRODUCTION}

Tagging plant virus clones with marker genes to track infection has considerably contributed to advance in plant virology in recent decades (Tilsner and Oparka, 2010). Pioneering works used tags to code for enzymes, e.g., acetyl chloramphenicol transferase or luciferase, which facilitated the quantification of virus replication (French et al., 1986; Joshi et al., 1990). The construction of an infectious clone of Tobacco etch virus, which harbored a heterologous cDNA that encoded bacterial enzyme beta-glucuronidase (GUS), was a step further because this recombinant clone permitted the cells and tissues where the virus expressed and replicated its genome to be visualized (Dolja et al., 1992). However, GUS activity had to be revealed by infiltrating plant tissues with an suitable chromogenic substrate. The incorporation of a new generation of markers, which encoded fluorescent proteins, definitively boosted this strategy to study plant viruses (Baulcombe et al., 1995). Unlike GUS, fluorescent proteins, like Aequorea 
victoria green fluorescent protein (GFP), do not need a substrate to be revealed (Chalfie et al., 1994; Rodriguez et al., 2016). We more recently introduced a new type of marker gene that allowed the visual monitoring of infected tissues by the naked eye without having to resort to complex instruments (Bedoya et al., 2012). Virus-mediated expression of snapdragon (Antirrhinum majus L.) MYB-type transcription factor Roseal induces the accumulation of reddish anthocyanins exclusively in tissues infected by the virus (Bedoya et al., 2012). A triad of transcription factors, namely an MYB, a bHLH and a WD40, form a ternary complex that activates the expression of anthocyanin biosynthetic genes (Zhang et al., 2014; Passeri et al., 2016). The MYB transcription factor is the limiting element of this complex (Allan et al., 2008), which explains why virus-mediated Rosea 1 expression closely correlates with the accumulation of anthocyanins, which is proportional to viral load (Bedoya et al., 2012). However, this technology is not universal and depends on factors like endogenous virus capacity to express foreign proteins or the affinity of $A$. majus Roseal to interact with companion endogenous transcription factors (Majer et al., 2017). Thus its applicability to a particular plant virus-host system must be tested.

Potato virus $Y$ (PVY) is currently considered the major viral threat to potato (Solanum tuberosum L.) cultivation (Karasev and Gray, 2013; Quenouille et al., 2013), and is ranked number 5 in the top 10 plant viruses in molecular plant pathology (Scholthof et al., 2011). This virus is the type member of the very large genus Potyvirus, and the family Potyviridae, of plusstrand RNA viruses (Gibbs and Ohshima, 2010). It has a wide host range that includes plants in nine botanical families, although economically important diseases concentrated in cultivated solanaceous plants like potato, tomato (S. lycopersicum L.), pepper (Capsicum spp.), tobacco (Nicotiana spp.) or petunia (Petunia spp.) (Quenouille et al., 2013). PVY is transmitted by more than 40 aphid (family Aphididae) species in a non-persistent manner. Transmission by worldwide distributed aphid Myzus persicae Sulz. is particularly efficient. Phylogenetic and epidemiologic analyses indicate that PVY originated in the Americas, but the virus is currently distributed worldwide (Quenouille et al., 2013). As it is typical of most potyviruses (genus Potyvirus), the PVY genome consists of an almost 10000 nucleotide (nt) long RNA molecule that is covalently linked at the 5' end to a viral protein genome-linked (VPg), and contains a poly(A) tail at the 3' end. This genomic RNA is encapsidated by approximately 2000 copies of a single coat protein $(\mathrm{CP})$ in elongated and flexuous virions. The viral genome encodes a large polyprotein and viral products (P1, HC-Pro, P3, 6K1, CI, 6K2, VPg, NIaPro, NIb and CP; Figure 1) result from a regulated cascade of proteolytic processing (Revers and García, 2015). 
An additional product (P3N-PIPO) results from a frameshift at the P3 cistron, recently shown to be generated through a polymerase slippage mechanism (Olspert et al., 2015; Rodamilans et al., 2015).

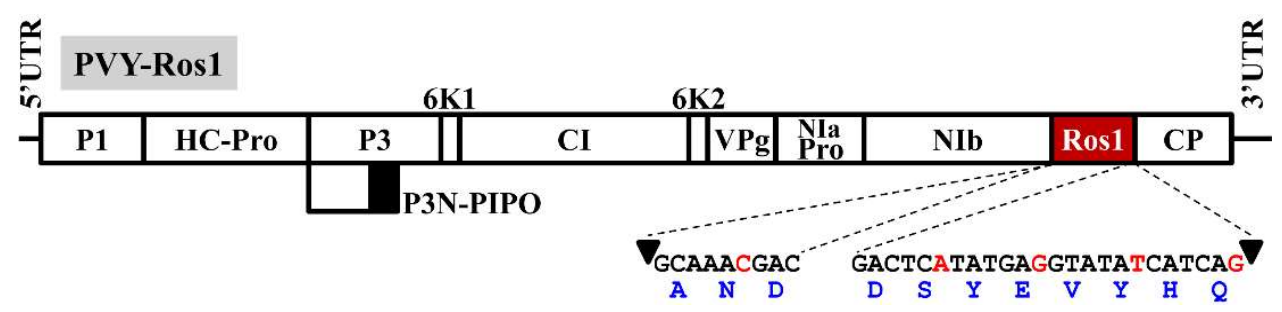

FIGURE 1. Schematic representation of the PVY recombinant clone in which transcription factor Rosea1 was expressed between NIb and CP: PVY-Ros1.

Lines represent the viral 5' and 3' untranslated regions (UTR), and boxes denote viral cistrons P1, HC-Pro, P3, P3N-PIPO, 6K1, CI, 6K2, VPg, NIaPro, NIb and CP, as indicated. Rosea1 (Ros1) is indicated by a red box. The nucleotide and amino acid sequences, added to both ends of Roseal to complement the split NIb/CP proteolytic site, are also indicated. Arrowheads indicate the cleavage site. The nucleotides in red correspond to silent mutations to avoid homologous repetitions in the PVY-Ros1sequence.

We wondered whether the Rosea1 visual marker could be applied to such a relevant virus as PVY, and, particularly whether the marker confers any advantage to either the aphid transmission analysis or the effect of antiviral treatments, among others. To this end, we built an infectious clone of a wild isolate of PVY tagged with Roseal (PVY-Ros1). We observed that this recombinant clone induced red spots in mechanically inoculated tissue, which is indicative of infection foci, and solid dark red coloration on upper non-inoculated leaves when systemic infection was established. Using silver nanoparticles, which are an easy-to-produce novel nanomaterial with exciting antimicrobial activities, we proved that PVY-Ros1 allows the very precise quantification of the effect of antiviral treatments in plants. Interestingly, aphids that fed on red-colored tissue efficiently transmitted the disease during a process that can be easily tracked thanks induction of discrete visible infection foci, which presumably surround the aphid puncture site during inoculation. Finally, we observed that PVY-Ros1 can be used in molecular farming to very quickly induce the production of large amounts of anthocyanins, antioxidant compounds with nutritional, pharmaceutical and industrial applications, in biofactory crops. 


\section{MATERIALS AND METHODS}

\section{Construction of a PVY Recombinant Clone Tagged with Rosea1}

RNA was purified using silica gel spin columns (Zymo Research) from potato leaf tissue infected with a wild Canadian isolate of PVY (RB strain). With this RNA preparation, three different cDNAs that covered the whole viral genome were synthesized using RevertAid reverse transcriptase (Thermo Scientific) and oligodeoxynucleotide primers PI to PIII (the sequences of all the primers used in this work are indicated in Supplementary Table S1). Each cDNA served as a template to amplify the PVY genome in three different fragments (5', central and 3') by the polymerase chain reaction (PCR) using Phusion high-fidelity DNA polymerase (Thermo Scientific) and primers PIV and PV (5' fragment), PVI and PVII (central fragment) and PVIII and PIX (3' fragment). These primers were flanked with the recognition site of typeIIS restriction enzyme Eco31I (Supplementary Table S1). Amplification products were cloned at the EcoRV site of pBS $\Delta \mathrm{E}$, a derivative of pBluescript II KS+ (GenBank accession number X52327.1), at which an Eco31I recognition site was mutagenized. A selected recombinant plasmid, which contained the central part of the PVY genome, was used as a template to mutagenize an endogenous Eco31I recognition site by PCR with primers PX and PXI by introducing a silent mutation. Another selected plasmid that contained the 3' fragment of the PVY genome was used as a template to insert a cDNA coding for the A. majus Roseal transcription factor (GenBank accession number DQ275529.1) between cistrons NIb and CP by PCR amplification with Phusion DNA polymerase, digestion with Eco31I (Thermo Scientific) and ligation with T4 DNA ligase (Thermo Scientific). The plasmid was opened by PCR using primers PXII and PXIII. Roseal cDNA was amplified with primers PXIV and PXV, and was flanked by extra sequences that encoded amino acids to complement the split NIb/CP NIaPro cleavage site (Figure 1). Finally, the cDNAs that corresponded to the 5 ' and central fragments of the PVY genome, as well as the 3' fragment with the Roseal insertion, were released from their respective plasmids using Eco31I. They were assembled (Engler and Marillonnet, 2014) in binary plasmid pG35Z (Cordero et al., 2017) by ligation with T4 DNA ligase. We named the resulting plasmid pGPVY-Ros1.

\section{Plant Inoculation}

For plant agroinoculation, strain $\mathrm{C} 58 \mathrm{C} 1$ of Agrobacterium tumefaciens, which harbored helper plasmid pCLEAN-S48 (Thole et al., 2007), was electroporated with pGPVY-Ros1. Transformed A. tumefaciens clones were first selected in plates with $50 \mu \mathrm{g} / \mathrm{ml}$ of kanamycin, 
$7.5 \mu \mathrm{g} / \mathrm{ml}$ of tetracycline and $50 \mu \mathrm{g} / \mathrm{ml}$ of rifampicin. The selected clones were further grown in liquid media at $28^{\circ} \mathrm{C}$ with only $50 \mu \mathrm{g} / \mathrm{ml}$ of kanamycin and were used to agroinoculate 4week-old Nicotiana benthamiana Domin plants in two leaves (Bedoya and Daròs, 2010). Liquid cultures of the transformed A. tumefaciens were grown to optical density at $600 \mathrm{~nm}$ $\left(\mathrm{OD}_{600}\right)$ of approximately 1.0. Cells were recovered by centrifugation and were resuspended at an $\mathrm{OD}_{600}$ of 0.5 in $10 \mathrm{mM}$ MES-NaOH, $\mathrm{pH} 5.6,10 \mathrm{mM} \mathrm{MgCl}_{2}$, and $150 \mu \mathrm{M}$ acetosyringone. Cultures were induced for $3 \mathrm{~h}$ at $28^{\circ} \mathrm{C}$ and were used to agroinoculate $N$. benthamiana plants. For the mechanical inoculation of plants, crude extracts of infected tissues, obtained in 20 volumes of $50 \mathrm{mM}$ of potassium phosphate, $\mathrm{pH} 8.0,1 \%$ polyvinylpyrrolidone $10,1 \%$ polyethylene glycol 6000 and $10 \mathrm{mM}$ of 2-mercaptoethanol, were rubbed on the leaf surface in the presence of carborundum using a cotton swab (Bedoya and Daròs, 2010). Five-week-old tobacco (Nicotiana tabacum L., cv. Xanthi nc), 4-week-old tomato (Solanum lycopersicum L., cv. Marglobe) and 6-week-old potato (traditional cultivar from Soria, Spain) plants were used for mechanical inoculation. In all cases, plants were kept in a growth chamber at $25^{\circ} \mathrm{C}$ under a 12-h day-night photoperiod. For aphid transmission, standard plant-to-plant transmission experiments were performed, as previously described (Atreya et al., 1995). Apterae individuals from a colony of M. persicae, kindly provided by A. Fereres (ICA-CSIC, Madrid, Spain), and reared in the laboratory on tobacco plants, were collected and kept in glass vials for a 2 -h fasting period. Aphids were allowed a 10-min acquisition access period on the PVY-Ros1-infected leaves, and were then transferred to the test plants, either individually or in groups of 5 or 10. After an overnight inoculation access period (14-18 h), aphids were killed by spraying with insecticide, and plants were placed in a growth chamber for symptoms to develop.

\section{PVY Diagnosis by RT-PCR}

The RNA preparations obtained from leaf tissue using silica gel spin columns were reversetranscribed with RevertAid reverse transcriptase and primer PIII. The reverse transcription products were PCR-amplified with Thermus thermophilus DNA polymerase (Biotools), using primers PXVI and PXVII to amplify the PVY CP cistron (801 bp), and were revealed by gel electrophoresis ( $1 \%$ agarose) and ethidium bromide staining.

\section{Synthesis of Silver Nanoparticles and Treatment of Plants}

Endophytic fungus Curvularia lunata was aerobically grown in potato dextrose broth at $26^{\circ} \mathrm{C}$ for 3 days with agitation. The fungal mat was washed with sterile water and an aliquot of $10 \mathrm{~g}$ was further agitated in $100 \mathrm{ml}$ of water for 2 days at $26^{\circ} \mathrm{C}$. The culture exudate was recovered 
by filtration with Whatman number 1 paper and was mixed with $100 \mathrm{ml}$ of $1 \mathrm{mM} \mathrm{AgNO}$. The mixture was then incubated in the dark at room temperature until color changed. The silver reduction reaction and the formation of silver nanoparticles were monitored for approximately 1 week by a spectrophotometric analysis. The resulting silver nanoparticles were purified, dried and characterized by spectroscopic and microscopic analyses, as previously described (AbdelHafez et al., 2016). A fine dispersion of silver nanoparticles in water at 1000 parts per million (ppm) was obtained by three cycles of 5-min stirring and 5-min sonication. From this dispersion, a 1:10 dilution in water $(100 \mathrm{ppm})$ was prepared. These silver nanoparticle preparations were sprayed on 5-week-old tobacco (cv. Xanthi nc) plants. Two days later, the true leaves 5 and 6 of these plants were mechanically inoculated with PVY-Ros1 in the presence of carborundum, as described above.

\section{Analysis of Anthocyanins}

The tissue samples from the systemic leaves from tobacco plants were collected at 12 days postinoculation (dpi), unless indicated, and frozen at $-80^{\circ} \mathrm{C}$. While frozen, these tissue samples were mechanically ground and mixed. For each sample, a representative aliquot of approximately 1 $\mathrm{g}$ of tissue was homogenized in 10 volumes of extraction solution $(1 \% \mathrm{HCl}$ in methanol) with a Polytron (Kinematica). Extracts were vigorously vortexed, incubated on ice for $1 \mathrm{~h}$ with sporadic vortexing, and finally clarified by centrifugation for $10 \mathrm{~min}$ at $12000 \mathrm{~g}$. Supernatants were diluted to $1: 10$ in extraction solution (final ratio tissue:extraction solution $1: 100$ ) and analyzed spectrophotometrically (UV-3100PC, VWR). Anthocyanin identification was done in a UPLC/PDA/qTOF-MS instrument (micromass Q-TOF micro, Waters). Separation was performed in an ACQUITY BEH C1 8 column $(150 \times 2.1 \mathrm{~mm}$ i.d., $1.7 \mu \mathrm{m})$ with a mobile phase that consisted of formic acid:water $(1: 1000 \mathrm{v} / \mathrm{v}$. phase A) and formic acid:acetonitrile $(1: 1000$ $\mathrm{v} / \mathrm{v}$; phase B). The gradient conditions were: $95 \% \mathrm{~A}$ for $5 \mathrm{~min}, 95 \%$ to $90 \% \mathrm{~A}$ in $14 \mathrm{~min}, 90 \%$ to $80 \% \mathrm{~A}$ in $15 \mathrm{~min}, 80 \%$ to $65 \% \mathrm{~A}$ in $10 \mathrm{~min}, 65 \%$ to $30 \% \mathrm{~A}$ in $5 \mathrm{~min}, 30 \%$ to $0 \% \mathrm{~A}$ in $1 \mathrm{~min}$, held at $100 \% \mathrm{~B}$ for $5 \mathrm{~min}$, returned to $95 \% \mathrm{~A}$ in $1 \mathrm{~min}$, and equilibrated for $4 \mathrm{~min}$ before the next injection. The flow rate was $0.4 \mathrm{ml} / \mathrm{min}$ and the sample injection volume was $5 \mu$ l. Column and sample temperatures were $40^{\circ} \mathrm{C}$ and $10^{\circ} \mathrm{C}$, respectively. UV-visible spectra were acquired within the wavelength range of 220 to $800 \mathrm{~nm}$ with $1.2-\mathrm{nm}$ resolution and a 20 points/s sampling rate. The MS analysis was performed by electrospray ionization in the negative mode. The mass spectrometry conditions were as follows: capillary voltage $2900 \mathrm{~V}$, cone voltage 30 $\mathrm{V}$; desolvation temperature $300^{\circ} \mathrm{C}$, source temperature $120^{\circ} \mathrm{C}$, cone gas flow $50 \mathrm{l} / \mathrm{h}$, desolvation gas flow 450 1/h. MS data were acquired in the centroid mode within an $\mathrm{m} / \mathrm{z}$ range of 100-1500 
in a scan time of $0.5 \mathrm{~s}$ and an interscan time of $0.1 \mathrm{~s}$. MS was calibrated using sodium formate, and leu-enkephalin was used as the lock mass with a LockSpray exact mass ionization source. MassLynx version 4.1 and Q-tof Micro version 4.1 (Waters) were used to control instruments and to calculate accurate masses.

\section{RESULTS AND DISCUSSION}

\section{A Recombinant PVY Clone Tagged with Rosea1 is Infectious and Induces a Dark Red Pigmentation of Infected Tissue}

To analyze whether the Rosea1 marker is operational to visually reveal PVY infected tissues, starting with a wild isolate of this virus, we constructed a full-length clone in which a cDNA coding for $A$. majus Roseal was inserted between the cistrons NIb and CP (PVY-Ros 1, Figure 1). Roseal cDNA was flanked by artificial sequences that code for amino acids to complement both sides of the split $\mathrm{NIb} / \mathrm{CP}$ proteolytic site. At the protein level, these sequences regenerate the original $\mathrm{NIb} / \mathrm{CP}$ cleavage site at both sides, but at the nucleotide level they include silent mutations to avoid sequence repetitions, which could facilitate marker deletion by homologous recombination during viral replication (Figure 1). The recombinant PVY-Ros1 clone was fully sequenced (Supplementary Dataset S1) and deposited in GenBank (accession number KY780083). Apart from Roseal and the sequences to complement proteolysis, a BLAST search indicated that cloned PVY mostly resembled a mild Canadian isolate of PVY (sequence variant RB of PVY-O isolate, GenBank accession number HM367076) (Nie et al., 2011). The sequences were $99.9 \%$ identical, and only differed in one insertion (A1) and five mutations (G4550A, A4907G, G5794A, A6533C, C7280T and A7338G; numbering corresponds to PVYRos1). Note that the G4550A silent mutation was introduced into the recombinant clone in order to eliminate an endogenous Eco31I recognition site and to facilitate manipulation. A6533C and C7280T are silent mutations, whereas A4907G, G5794A and A7338G induce amino acid substitutions I1574 M, S1870N and T2385A with respect to HM367076.

Three $N$. benthamiana plants were agroinoculated in two leaves with an A. tumefaciens clone, which harbored plasmid pGPVY-Ros1 that contained PVY-Ros1. One of the three agroinoculated plants showed infection symptoms at 26 dpi in upper non-inoculated leaves. Interestingly, symptomatic tissues turned red (Figure 2A). Considering the relatively low infection rate observed in this agroinoculation experiment, a similar set of three $N$. benthamiana plants was directly inoculated mechanically with plasmid pGPVY-Ros1. One of the three 
mechanically inoculated plants also displayed infection symptoms at $31 \mathrm{dpi}$, which also turned red. We used infected tissue from these plants to prepare crude extracts to mechanically inoculate tobacco ( $N$. tabacum) plants. All the mechanically inoculated leaves started to show red infectious foci at $5 \mathrm{dpi}$, which were clearly visible at 6 dpi (Figure 2B). All the mechanically inoculated plants started to show infection symptoms on their upper non-inoculated leaves at 6 dpi, which were easily recognized thanks to the simultaneous red pigmentation. In all the inoculated plants, symptomatic tissue showed intense solid dark red coloration at 12 dpi (Figure 2C). When these same infectious extracts were used to mechanically inoculate potato and tomato plants, all the plants also became infected and exhibited red pigmentation in infected tissue (Figure 2D and E).

An RT-PCR analysis of the tissues from the tobacco mock-inoculated controls and infected plants (8 dpi) demonstrated that red symptomatic tissues accumulated PVY-Ros1. The electrophoretic analysis of the amplification product revealed a specific band whose size matched the 801-bp size expected for the PVY cistron CP in the samples that corresponded to the PVY-Ros1-infected plants (Figure 3). The sequence analysis of these PCR products confirmed PVY identity.

Taken together, these results indicated that the recombinant clone PVY-Ros1 contained in plasmid pGPVY-Ros1 was infectious and efficiently expressed the A. majus Rosea1 transcription factor which, at the time, activated anthocyanin biosynthesis in the infected tissues of the different tested solanaceous hosts: $N$. benthamiana, N. tabacum, potato and tomato. However, the results also suggested that pGPVY-Ros1 was rather an unstable plasmid because, when starting with the plasmid, the infection rate obtained by either agroinoculation or direct mechanical inoculation was low. Instability of the plasmids that contain full-length clones of plant RNA viruses is frequent (Boyer and Haenni, 1994; Bedoya and Daròs, 2010). In addition to low infectivity, infection from plasmid (either by agroinoculation or mechanical inoculation) also showed an extended delay compared to the mechanical inoculation using an infectious extract. This suggests poor expression efficiency of viral full-length cDNA. As the expression in this construct was driven by the very strong Cauliflower mosaic virus (CaMV) 35S promoter and terminator, one possible explanation for this low infectivity could be presence of cryptic introns in the PVY sequence, which could result in undesired splicing in most transcripts. The 


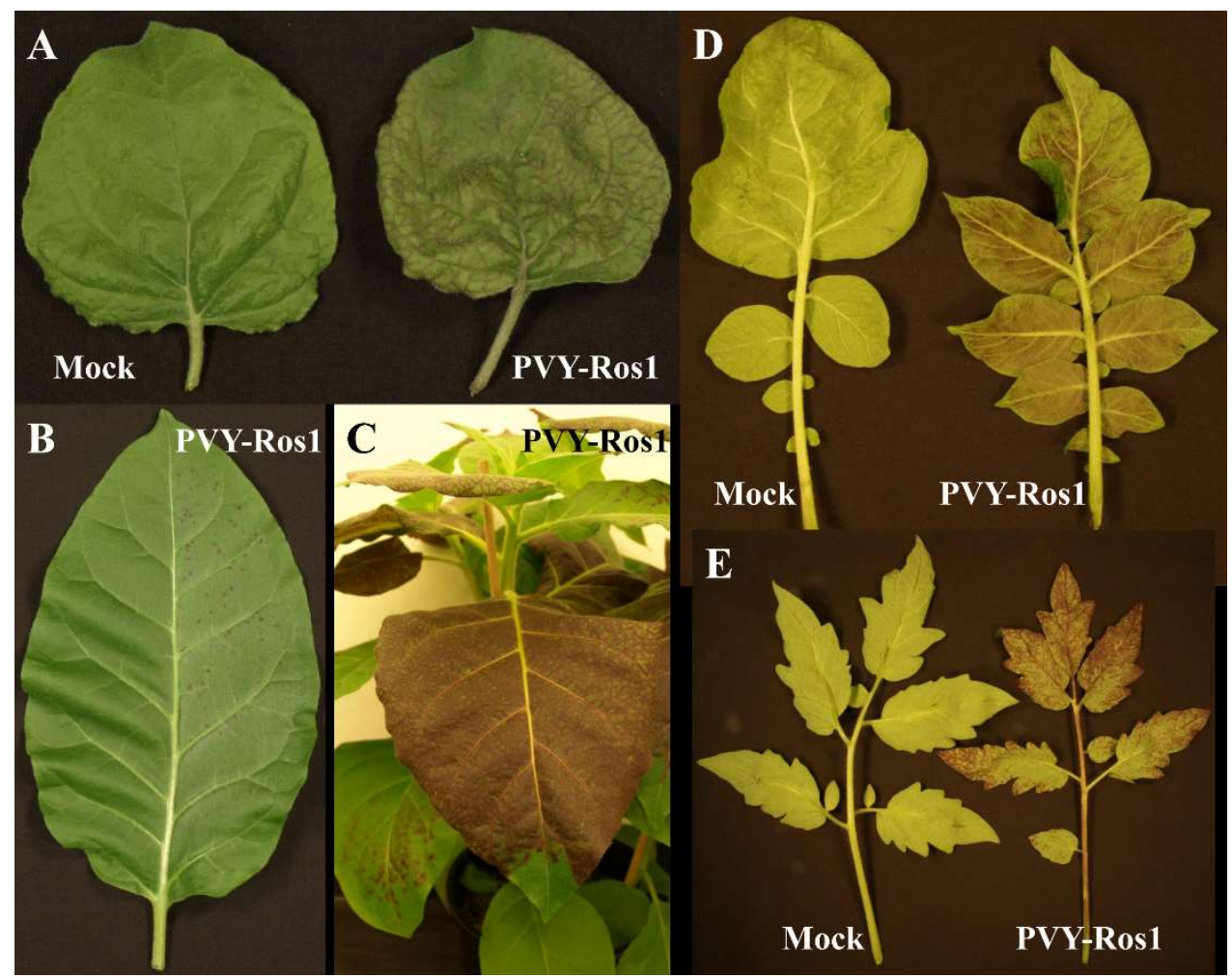

FIGURE 2. Plants infected with PVY-Ros1 that show red pigmentation.

(A) Upper non-inoculated leaves from mock (left) and PVY-Ros1 (right) agroinoculated N. benthamiana plants showing veinal-associated anthocyanin accumulation. (B) N. tabacum leaf mechanically inoculated (right side) with PVY-Ros1. The picture was taken at 6 dpi. (C) Detail of an N. tabacum plant infected with PVY-Ros1 (11 dpi) showing solid dark red pigmentation. (D and E) Upper non-inoculated leaves from potato (D) and tomato (E) plants mock-inoculated (left) and mechanically inoculated with PVY-Ros1 (right). Pictures were taken at 6 and 19 dpi, respectively.

undesired presence of cryptic introns has been previously shown in Tobacco mosaic virus (Marillonnet et al., 2005). Although, presence of cryptic introns has never been shown in the case of potyviruses, conversely intron insertion has been used to enhance clone stability and infectivity (Johansen, 1996; López-Moya and García, 2000). In any case, our experiments indicated the possibility of inducing infection with PVY-Ros1 by both agroinoculation and direct mechanical inoculation of pGPVY-Ros1. Most importantly, after obtaining some initial infected tissue, it could be used as a fast and efficient source of PVY-Ros1 inoculum for successive experiments. Nonetheless, infection efficiency of agroinoculated PVY-Ros 1 may be improved by the co-expression of tombusvirus p19 silencing suppressor (Saxena et al., 2011). Recently, a PVY clone tagged with GFP has been proposed as a versatile tool for the functional analysis of plant-virus interaction (Rupar et al., 2015). Based on direct visual detection, PVYRos 1 must be able to complement this tool with new experimental possibilities. 


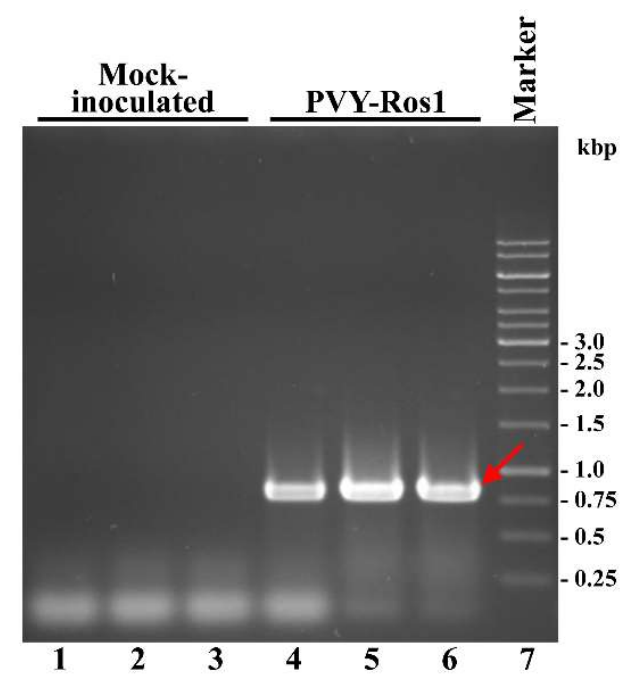

FIGURE 3. Diagnosis of PVY-Ros1 in tobacco plants by RT-PCR.

Amplification products from the RNA preparations of three plants mock-inoculated (lanes 1 to 3), and inoculated with PVY-Ros1 (lanes 4 to 6), were separated by electrophoresis in agarose gel and revealed by ethidium bromide staining. Lane 7 contains a DNA marker with sizes in bp on the right. The red arrow points to the amplification product that corresponds to cistron PVY CP (801 bp).

\section{PVY-Ros1 Facilitates the Quantitative Analysis of the Antiviral Activity of Silver Nanoparticles}

The speed and easiness with which PVY-Ros1-derived red spots and patterns are monitored or recorded in real time without having to resort to complex instrumentation make this recombinant virus an excellent tool to analyze the effect of environmental growth conditions, the host genetic background or phytosanitary treatments in virus infection. To acquire proof of this concept, we thought about treating tobacco plants with silver nanoparticles, a novel kind of nanomaterial for which exciting antimicrobial activities have been reported (Mishra and Singh, 2015), and then inoculating the treated tissues with PVY-Ros1. Sets of six tobacco plants (6 weeks old) were sprayed with a preparation of $C$. lunata-derived silver nanoparticles at 100 ppm and 1000 ppm in water. In this experiment, we included a set of mock-sprayed plants. Two days later, two leaves per plant were mechanically inoculated with aliquots of the same PVYRos 1 inoculum. Red infection foci were clearly visible at 6 dpi (Figure 4A). The inoculated leaves were harvested and foci were counted (Supplementary Table S2). Whereas an average of 233 individual infection foci per leaf was observed on the mock inoculated leaves, only an average of 87 and 22 foci was observed on the leaves treated with $100 \mathrm{ppm}$ and $1000 \mathrm{ppm}$ of silver nanoparticles, respectively (Figure 4B). Hence the use of PVY-Ros1 very precisely showed the protective effect of silver nanoparticles against infection by a plant RNA virus. 
Antiviral activity of silver nanoparticles has been repeatedly shown in human viruses (Lu et al., 2008; Lara et al., 2011) or bacteriophages (Narasimha et al., 2012), but in only one recent report in plant viruses (Elbeshehy et al., 2015). It is interesting to note that while in this report authors did not detect any beneficial effect of silver nanoparticles in pre-infection treatment and only remarkable positive results were observed in post-infection treatment (Elbeshehy et al., 2015), we clearly observed a significant beneficial effect of silver nanoparticles in treatments $48 \mathrm{~h}$ ahead of viral challenging thanks to the Rosea1-based easy monitoring of infection foci.
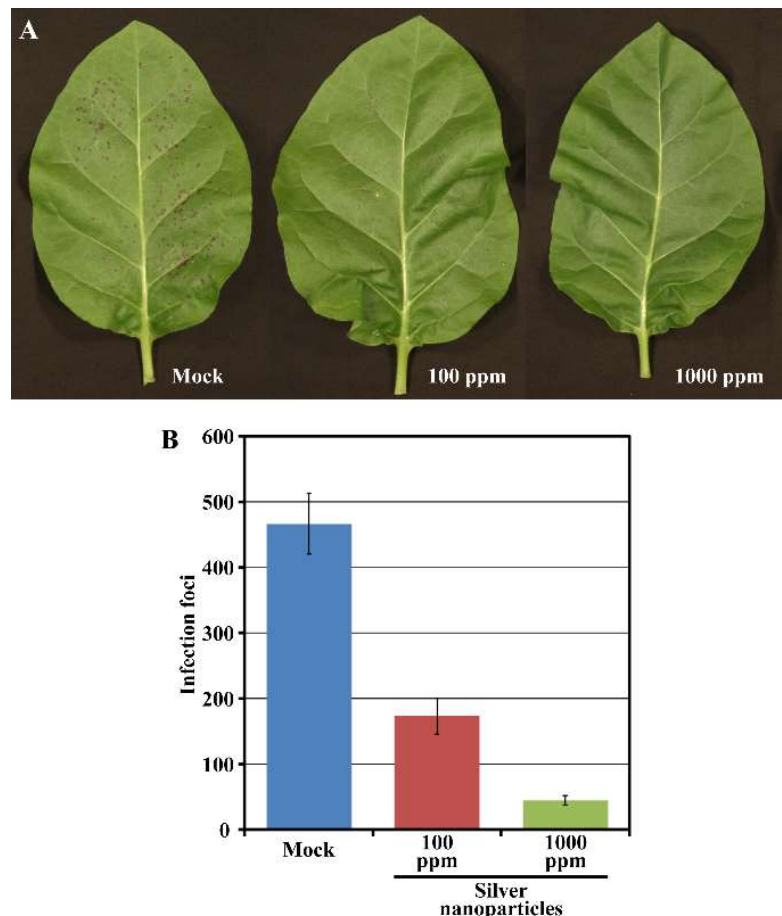

FIGURE 4. Effect of silver nanoparticles on PVY-Ros1 infectivity.

(A) Pictures of representative leaves of tobacco plants mock-treated or sprayed with a preparation of silver nanoparticles in water at 100 and 1000 ppm, as indicated. Two days after treatment, leaves were mechanically inoculated with PVY-Ros1. Pictures were taken at 6 dpi with PVY-Ros1. (B) Histogram of the average number of infection foci per leaf of the six plants treated with silver nanoparticles, as indicated, and mechanically inoculated with PVY-Ros 12 days later. Foci were quantified at 6 dpi with PVY-Ros1. Error bars represent the standard error median.

\section{PVY-Ros1 Enables the Visual Monitoring of Aphid Transmission}

Most plant viruses are transmitted by vectors. In the particular case of potyviruses, transmission by aphids is a distinctive trait of the genus. We wondered whether the Roseal marker would allow the visual monitoring of the aphid transmission process. To this end, and after a standard starvation period, aphid populations were allowed to feed on red-colored PVY-Ros1-infected tobacco tissue for $10 \mathrm{~min}$ to acquire the virus. Next they were individually transferred at 
different densities to healthy tobacco test plantlets and confined there for overnight inoculation. Some plantlets were excluded from aphid inoculation to serve as controls, and a subgroup of them was mechanically inoculated (positive controls). Aphids were finally eliminated by insecticide treatment. Unlike the control plants into which no aphids were released, red spots started to appear 5 days later in some of the plants had come into contact with the viruliferous aphids (Figure 5A), and at the same time as in the mechanically inoculated controls (Figure 5B). Later, all these plants exhibited infection symptoms on their upper non-inoculated leaves, as well as red coloration. Table 1 summarizes the results of eleven independent experiments to compare the virus transmission rate at three different aphid densities. In all cases, viral infection was easily monitored by the appearance of a red coloration induced by the Roseal marker. The aphid-mediated PVY-Ros1 transmission rate ranged from $84 \%$ at a vector density of 10 aphids per plant to $23 \%$ at 1 aphid per plant (Table 1). All the plants with red infection foci on their inoculated leaves later developed systemic infection. Once again, the ease of monitoring aphidmediated virus transmission makes PVY-Ros1 an excellent tool to quantify the effect of phytosanitary treatments on disease transmission by viruliferous vectors. Incidentally we observed that compared to the mechanically inoculated plants in which the vast majority of infection foci were circular (e.g., see Figure 2B), the plants inoculated by aphids showed a large proportion of irregularly shaped and elongated foci that developed along leaf nerves (Figure 5A). This observation suggests that the epidermal cells from the leaf surface are initially infected during mechanical inoculation, while aphid-mediated inoculation may more frequently initiate infection in vascular tissue. Tracking the initial stages of virus infection by insect vectors was recently reported for a transmissible variant of Cucumber mosaic virus tagged with GFP (Krenz et al., 2015). Our results indicate that PVY-Ros1 can be used to learn about the inoculation sites by aphids in potyviruses.

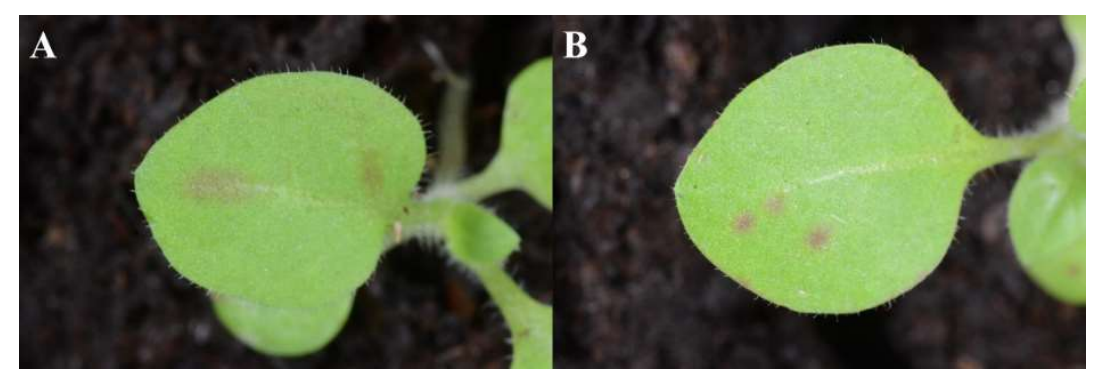

FIGURE 5. Visual monitoring of the PVY-Ros1 aphid transmission process.

Details of representative tobacco plants inoculated with PVY-Ros1 (A) using viruliferous aphids or (B) mechanically. Aphid transmission frequently produced elongated red infection foci suggesting inoculation in vascular bundles. Pictures were taken at $5 \mathrm{dpi}$. 
TABLE 1. Aphid transmission of PVY-Ros1.

\begin{tabular}{|c|c|c|c|c|}
\hline \multirow{2}{*}{$\begin{array}{c}\text { Number } \\
\text { of aphids }\end{array}$} & \multirow{2}{*}{$\begin{array}{c}\text { Number of } \\
\text { repetitions }\end{array}$} & \multicolumn{3}{|c|}{ Transmission } \\
\cline { 3 - 5 } & Total $^{\mathbf{1}}$ & Percentage & Range $^{2}$ \\
\hline 10 & 4 & $38 / 45$ & $84.4 \%$ & $66.7-100$ \\
\hline 5 & 3 & $14 / 32$ & $43.8 \%$ & $16.7-62.5$ \\
\hline 1 & 4 & $11 / 48$ & $22.9 \%$ & $0-33.3$ \\
\hline
\end{tabular}

${ }^{1}$ Number of infected plants over number of test plants. Data combined from the number of repeated experiments as indicated.

${ }^{2}$ Range of transmission rates for each individual repetition of the experiment is indicated. When corrected by number of aphids (transmission per aphid), rates did not significantly differ at the 0.05 level according to the Tukey (HSD) test.

\section{PVY-Ros1 as a Molecular Farming Tool to Produce Anthocyanins in Biofactory Plants}

Anthocyanins are water-soluble natural pigments produced in plants, which have been paid close attention thanks to their health-promoting properties (Zhang et al., 2014; Passeri et al., 2016). While performing the previously described experiments, we were astonished by the red pigmentation intensity induced by PVY-Ros1, particularly in tobacco plants (e.g., see Figure 2C). We envisioned that PVY-Ros1 could also be used in molecular farming to very quickly induce large accumulations of anthocyanins in biofactory plants. With this idea in mind, we studied the dynamics of PVY-Ros1-induced anthocyanin accumulation in tobacco plants, identified the main anthocyanin produced in the infected tissues of tobacco and estimated anthocyanin yields. For this purpose, we mechanically inoculated a series of 5-week-old tobacco plants with PVY-Ros1 in one leaf and harvested the upper non-inoculated tissue at different dpi (Figure 6A). From these tissues, anthocyanins were extracted in acidified methanol and quantified by a spectrophotometric analysis. Figure 6B compares the ultravioletvisible absorption spectra of two extracts obtained from the same plant. The green extract (green line in spectra) was obtained from lower non-symptomatic tissue and the dark red extract (red line) from upper symptomatic tissue. An intense absorption band centered at $530 \mathrm{~nm}$ indicated the vast accumulation of anthocyanins in the latter tissue. An analysis of the absorbance in extracts from the tissue collected at different dpi showed that substantial amounts of anthocyanins started to accumulate in infected tissues at around $8 \mathrm{dpi}$ and reached the maximum accumulation at around 12 dpi (Figure 6C). A high performance liquid chromatography (HPLC), coupled to mass spectrometry (MS), analysis of an extract that corresponded to $12 \mathrm{dpi}$ 
indicated that cyanidin-3-O-rutinoside (antirrhinin) was the main anthocyanin present in the extract (Figure 6D). When considering the molar extinction coefficient of this species $(26,900$ $\mathrm{M}^{-1} \mathrm{~cm}^{-1}$ ), we estimated that accumulation was around $275 \mathrm{mg}$ of anthocyanin per $100 \mathrm{~g}$ of tobacco fresh tissue. This amount is similar to those that accumulate in fruits and other plant tissues distinguished for their high anthocyanin content (Wu et al., 2006; Zhao et al., 2013). In order to avoid unnecessary speculations, we compared the anthocyanin content of the PVYRos1-infected tobacco tissue (12 dpi) with some seasonal fruits and vegetables that we purchased in a local market. Extracts were obtained under the same conditions using acidified methanol and anthocyanins were quantified by a spectrophotometric analysis. Interestingly, this analysis indicated that the anthocyanin accumulation in the PVY-Ros1-infected tobacco tissue was greater than that in blackberries, red cabbage, blueberries, raspberries, red onion or pomegranate (Figure 7).

While the PVY-Ros1/tobacco system produces large amounts of natural anthocyanin cyanidin3-O-rutinoside, the co-expression or silencing of some particular enzymes of the anthocyanin biosynthetic pathway or vacuole transporters may allow the efficient production of novel anthocyanins with a particular commercial value. These enzymes may be expressed using the same virus or other viral vectors, e.g. those that derive from Tobacco mosaic virus or Potato virus $X$, which produce compatible infections with PVY. Potyvirus-derived vectors can coexpress several proteins whose cDNAs are inserted into different virus genome positions (Kelloniemi et al., 2008), or into a single expression cassette (Bedoya et al., 2010; Majer et al., 2017).

Substantial amounts of anthocyanins have also been reported in transgenic tobacco plants that express sweet potato (Ipomoea batatas [L.] Lam) transcription factor IbMYB1a. The greatest accumulation, that of $110 \mathrm{mg}$ per $100 \mathrm{~g}$ fresh tissue, has been reported in the leaves of a line in which this transcription factor was expressed under the control of the sporamin promoter (An et al., 2015). This means that the virus-based strategy described herein produced a larger amount of anthocyanins (about 2.5-fold) by a much less complicated process than plant stable transformation. Moreover, our virus vector strategy used adult plants in which developmental 

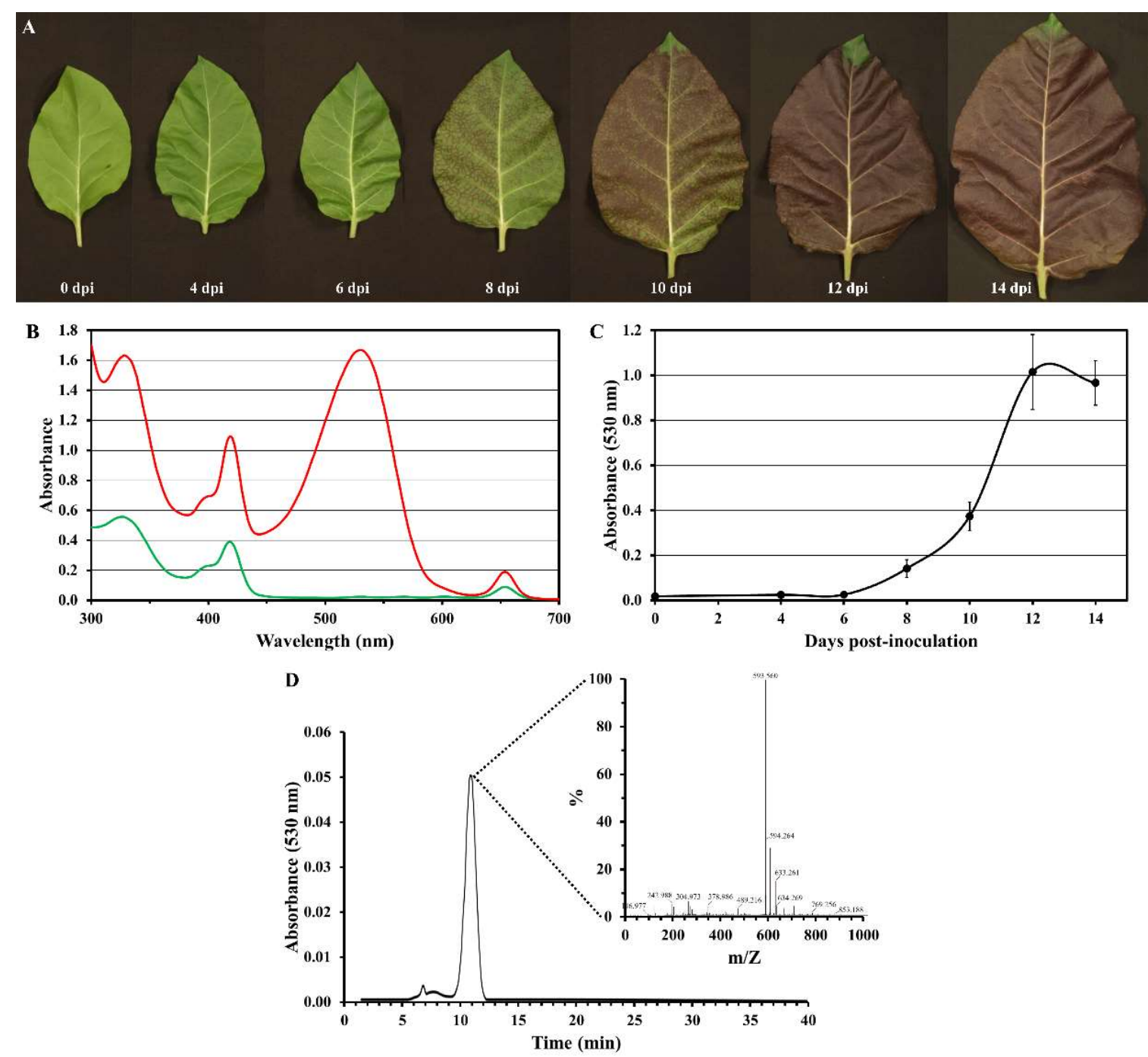

\section{FIGURE 6. PVY-Ros1-mediated anthocyanin production in tobacco plants.}

(A) Representative upper non-inoculated leaves sampled from plants mechanically inoculated with PVY-Ros1. Pictures were taken at different dpi, as indicated. (B) Absorption spectra of the methanol extracts obtained from lower non-symptomatic (green line) and upper symptomatic (red line) tissue from a PVY-Ros1-infected tobacco plant (12 dpi). (C) Plot of average absorbance at $530 \mathrm{~nm}$ versus time post-inoculation of the methanol extracts from the upper non-inoculated tissues of the tobacco plants infected with PVY-Ros1. Error bars represent the standard error median. (D) Identification of cyanidin-3-O-rutinoside in the extracts of PVY-Ros1 infected tobacco tissue by a HPLC separation coupled to MS analysis.

problems induced by high anthocyanin accumulation were avoided. In this way, using plant virus-derived systems to express the enzymes or regulatory factors involved in the biosynthesis of valuable compounds may add a series of advantages compared to transgenic plants. First, viral genomes can be quickly and easily manipulated. Second, the production of compounds of interest can be triggered in adult plants. Third, products of interest can be harvested only a few days after inoculation. We previously showed the production of lycopene and other carotenoids 
in tobacco tissues using a TEV-derived vector that expresses biosynthetic enzymes of bacterial origin (Majer et al., 2017). Unfortunately, unlike stable transformation strategies, the amount of genetic information that can be expressed using plant viruses is limited. We envision that the combined use of recombinant plant viruses and genetically transformed host plants will extend the possibilities of producing valuable compounds in increasingly more sophisticated molecular farming approaches.

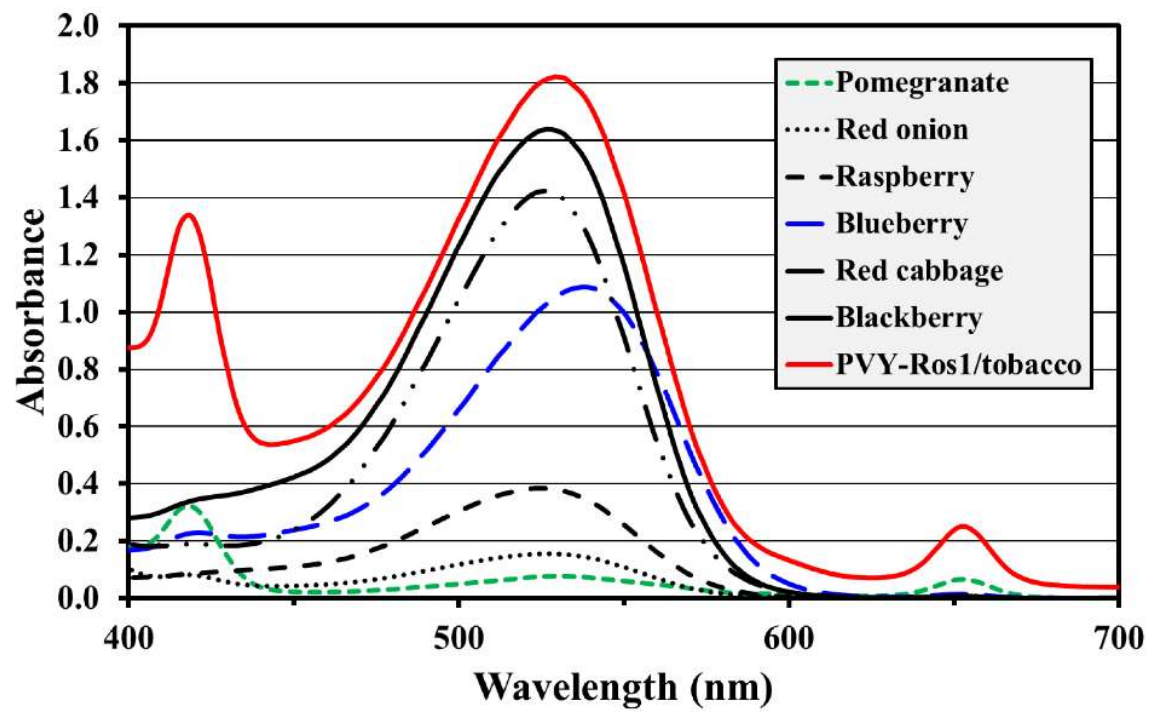

FIGURE 7. Comparison of anthocyanin accumulation in PVY-Ros1-infected tissue with different fruits and vegetables.

Visible spectra (400-700 nm) of the extracts obtained with acidified methanol (ratio $100 \mathrm{ml}$ per $1 \mathrm{~g}$ fresh weight) from PVY-Ros1-infected tobacco leaves (red line) and different fruits and vegetables, as indicated.

\section{PVY-Ros1 is a Versatile Biotechnological Tool that Serves Multiple Purposes}

In conclusion, in this work we built an infectious recombinant PVY clone that efficiently expresses the A. majus MYB-type Rosea1 transcription factor, which strongly activates anthocyanin accumulation in infected tissues. Whereas the plasmid in which the recombinant virus was contained (pGPVY-Ros1) was rather unstable when amplified in E. coli or $A$. tumefaciens, and was not easy to deal with, the recombinant virus (PVY-Ros1) generated in a host plant was highly infectious and stable. By using PVY-Ros1 as an inoculum, we demonstrated how infection foci and infected plants can be easily quantified by the naked eye without having to resort to molecular analyses or complex instrumentation. Our experimental results also showed how PVY-Ros1 facilitated the analyses of phytosanitary products, such as silver nanoparticles, or allowed the monitoring of virus aphid transmission, an essential process for disease dissemination. Finally, we also demonstrated how PVY-Ros1 can be used in 
molecular farming to trigger the production of large amounts of antioxidant anthocyanins (275 mg per $100 \mathrm{~g}$ of fresh weight) in biofactory plants in only 12 days.

\section{ACKNOWLEDGEMENTS}

We thank Veronica Aragonés for her excellent technical assistance, and José Luis Rambla and Antonio Granell (IBMCP, CSIC-UPV, Valencia) for their valuable help with the anthocyanin analysis. We also thank Sébastien Boquel (Agriculture and Agri-Food, Canada) for his valuable help in this research.

\section{REFERENCES}

Abdel-Hafez, S.I.I., Nafady, N.A., Abdel-Rahim, I.R., Shaltout, A.M., Daròs, J.-A., and Mohamed, M.A. (2016). Assessment of protein silver nanoparticles toxicity against pathogenic Alternaria solani. 3 Biotech. 6, 199. doi: 10.1007/s13205-016-0515-6.

Allan, A.C., Hellens, R.P., and Laing, W.A. (2008). MYB transcription factors that colour our fruit. Trends Plant Sci. 13, 99-102. doi: 10.1016/j.tplants.2007.11.012.

An, C.H., Lee, K.W., Lee, S.H., Jeong, Y.J., Woo, S.G., Chun, H., et al. (2015). Heterologous expression of $I b M Y B I a$ by different promoters exhibits different patterns of anthocyanin accumulation in tobacco. Plant. Physiol. Biochem. 89, 1-10. doi: 10.1016/j.plaphy.2015.02.002.

Atreya, P.L., Lopez-Moya, J.J., Chu, M., Atreya, C.D., and Pirone, T.P. (1995). Mutational analysis of the coat protein $\mathrm{N}$-terminal amino acids involved in potyvirus transmission by aphids. J. Gen. Virol. 76, 265-270. doi: 10.1099/0022-1317-76-2-265.

Baulcombe, D.C., Chapman, S., and Santa Cruz, S. (1995). Jellyfish green fluorescent protein as a reporter for virus infections. Plant J. 7, 1045-1053.

Bedoya, L., Martínez, F., Rubio, L., and Daròs, J.A. (2010). Simultaneous equimolar expression of multiple proteins in plants from a disarmed potyvirus vector. J. Biotechnol. 150, 268275. doi: 10.1016/j.jbiotec.2010.08.006.

Bedoya, L.C., and Daròs, J.A. (2010). Stability of Tobacco etch virus infectious clones in plasmid vectors. Virus Res. 149, 234-240. 
Bedoya, L.C., Martínez, F., Orzáez, D., and Daròs, J.A. (2012). Visual tracking of plant virus infection and movement using a reporter MYB transcription factor that activates anthocyanin biosynthesis. Plant Physiol. 158, 1130-1138. doi: 10.1104/pp.111.192922.

Boyer, J.C., and Haenni, A.L. (1994). Infectious transcripts and cDNA clones of RNA viruses. Virology 198, 415-426.

Cordero, T., Cerdán, L., Carbonell, A., Katsarou, K., Kalantidis, K., and Daròs, J.A. (2017). Dicer-Like 4 is involved in restricting the systemic movement of Zucchini yellow mosaic virus in Nicotiana benthamiana. Mol. Plant Microbe Interact. 30: 63-71. doi: 10.1094/MPMI-11-16-0239-R.

Chalfie, M., Tu, Y., Euskirchen, G., Ward, W.W., and Prasher, D.C. (1994). Green fluorescent protein as a marker for gene expression. Science 263, 802-805.

Dolja, V.V., McBride, H.J., and Carrington, J.C. (1992). Tagging of plant potyvirus replication and movement by insertion of b-glucuronidase into the viral polyprotein. Proc. Natl. Acad. Sci. USA 89, 10208-10212.

Elbeshehy, E.K., Elazzazy, A.M., and Aggelis, G. (2015). Silver nanoparticles synthesis mediated by new isolates of Bacillus spp., nanoparticle characterization and their activity against bean yellow mosaic virus and human pathogens. Front. Microbiol. 6, 453. doi: 10.3389/fmicb.2015.00453.

Engler, C., and Marillonnet, S. (2014). Golden Gate cloning. Methods Mol. Biol. 1116, 119131. doi: 10.1007/978-1-62703-764-8_9.

French, R., Janda, M., and Ahlquist, P. (1986). Bacterial gene inserted in an engineered RNA virus: efficient expression in monocotyledonous plant cells. Science 231, 1294-1297. doi: 10.1126/science.231.4743.1294.

Gibbs, A., and Ohshima, K. (2010). Potyviruses and the digital revolution. Annu. Rev. Phytopathol. 48, 205-223.

Johansen, I.E. (1996). Intron insertion facilitates amplification of cloned virus cDNA in Escherichia coli while biological activity is reestablished after transcription in vivo Proc. Natl. Acad. Sci. USA 93, 12400-12405.

Joshi, R.L., Joshi, V., and Ow, D.W. (1990). BSMV genome mediated expression of a foreign gene in dicot and monocot plant cells. EMBO J. 9, 2663-2669. 
Karasev, A.V., and Gray, S.M. (2013). Continuous and emerging challenges of Potato virus $Y$ in potato. Annu. Rev. Phytopathol. 51, 571-586. doi: 10.1146/annurev-phyto-082712102332.

Kelloniemi, J., Mäkinen, K., and Valkonen, J.P. (2008). Three heterologous proteins simultaneously expressed from a chimeric potyvirus: infectivity, stability and the correlation of genome and virion lengths. Virus Res. 135, 282-291.

Krenz, B., Bronikowski, A., Lu, X., Ziebell, H., Thompson, J.R., and Perry, K.L. (2015) Visual monitoring of Cucumber mosaic virus infection in Nicotiana benthamiana following transmission by the aphid vector Myzus persicae. J. Gen. Virol. 96, 2904-2912. doi: 10.1099/vir.0.000185

Lara, H.H., Ixtepan-Turrent, L., Garza Trevino, E.N., and Singh, D.K. (2011). Use of silver nanoparticles increased inhibition of cell-associated HIV-1 infection by neutralizing antibodies developed against HIV-1 envelope proteins. J. Nanobiotechnol. 9, 38. doi: 10.1186/1477-3155-9-38.

López-Moya, J.J., and García, J.A. (2000). Construction of a stable and highly infectious introncontaining cDNA clone of plum pox potyvirus and its use to infect plants by particle bombardment. Virus Res. 68, 99-107.

Lu, L., Sun, R.W., Chen, R., Hui, C.K., Ho, C.M., Luk, J.M., et al. (2008). Silver nanoparticles inhibit hepatitis B virus replication. Antivir. Ther. 13, 253-262.

Majer, E., Llorente, B., Rodríguez-Concepción, M., and Daròs, J.A. (2017). Rewiring carotenoid biosynthesis in plants using a viral vector. Sci. Rep. 7, 41645. doi: $10.1038 /$ srep41645.

Marillonnet, S., Thoeringer, C., Kandzia, R., Klimyuk, V., and Gleba, Y. (2005). Systemic Agrobacterium tumefaciens-mediated transfection of viral replicons for efficient transient expression in plants. Nat. Biotechnol. 23, 718-723.

Mishra, S., and Singh, H.B. (2015). Biosynthesized silver nanoparticles as a nanoweapon against phytopathogens: exploring their scope and potential in agriculture. Appl. Microbiol. Biotechnol. 99, 1097-1107. doi: 10.1007/s00253-014-6296-0.

Narasimha, G., Khadri, H. and Alzohairy, M. (2012). Antiviral properties of silver nanoparticles synthesized by Aspergillus spp. Der Pharmacia Lettre 4, 649-651. 
Nie, B.H., Singh, M., Sullivan, A., Singh, R.P., Xie, C.H., and Nie, X.Z. (2011). Recognition and molecular discrimination of severe and mild PVY-O variants of Potato virus $Y$ in potato in New Brunswick, Canada. Plant Dis. 95, 113-119. doi: 10.1094/pdis-04-100257.

Olspert, A., Chung, B.Y., Atkins, J.F., Carr, J.P., and Firth, A.E. (2015). Transcriptional slippage in the positive-sense RNA virus family Potyviridae. EMBO Rep. 16, 995-1004. doi: 10.15252/embr.201540509.

Passeri, V., Koes, R., and Quattrocchio, F.M. (2016). New challenges for the design of high value plant products: stabilization of anthocyanins in plant vacuoles. Front. Plant Sci. 7, 153. doi: 10.3389/fpls.2016.00153.

Quenouille, J., Vassilakos, N., and Moury, B. (2013). Potato virus $Y$ : a major crop pathogen that has provided major insights into the evolution of viral pathogenicity. Mol. Plant Pathol. 14, 439-452. doi: 10.1111/mpp.12024.

Revers, F., and García, J.A. (2015). Molecular biology of potyviruses. Adv. Virus Res. 92, 101199. doi: 10.1016/bs.aivir.2014.11.006.

Rodamilans, B., Valli, A., Mingot, A., San León, D., Baulcombe, D., López-Moya, J.J., et al. (2015). RNA polymerase slippage as a mechanism for the production of frameshift gene products in plant viruses of the Potyviridae family. J. Virol. 89, 6965-6967. doi: 10.1128/JVI.00337-15.

Rodriguez, E.A., Campbell, R.E., Lin, J.Y., Lin, M.Z., Miyawaki, A., Palmer, A.E., et al. (2016). The growing and glowing toolbox of fluorescent and photoactive proteins. Trends Biochem. Sci. doi: 10.1016/j.tibs.2016.09.010.

Rupar, M., Faurez, F., Tribodet, M., Gutiérrez-Aguirre, I., Delaunay, A., Glais, L., et al. (2015). Fluorescently tagged Potato virus Y: a versatile tool for functional analysis of plant-virus interactions. Mol. Plant Microbe Interact. 28, 739-750. doi: 10.1094/mpmi-07-14-0218ta.

Saxena, P., Hsieh, Y.C., Alvarado, V.Y., Sainsbury, F., Saunders, K., Lomonossoff, G.P., et al . (2011). Improved foreign gene expression in plants using a virus-encoded suppressor of RNA silencing modified to be developmentally harmless. Plant Biotechnol. J. 9, 703712. doi: 10.1111/j.1467-7652.2010.00574.x. 
Scholthof, K.B., Adkins, S., Czosnek, H., Palukaitis, P., Jacquot, E., Hohn, T., et al. (2011). Top 10 plant viruses in molecular plant pathology. Mol. Plant Pathol. 12, 938-954. doi: 10.1111/j.1364-3703.2011.00752.x.

Thole, V., Worland, B., Snape, J.W., and Vain, P. (2007). The pCLEAN dual binary vector system for Agrobacterium-mediated plant transformation. Plant Physiol. 145, 1211-1219.

Tilsner, J., and Oparka, K.J. (2010). Tracking the green invaders: advances in imaging virus infection in plants. Biochem. J. 430, 21-37. doi: 10.1042/BJ20100372.

Wu, X.L., Beecher, G.R., Holden, J.M., Haytowitz, D.B., Gebhardt, S.E., and Prior, R.L. (2006). Concentrations of anthocyanins in common foods in the United States and estimation of normal consumption. J. Agric. Food Chem. 54, 4069-4075. doi: 10.1021/jf060300i.

Zhang, Y., Butelli, E., and Martin, C. (2014). Engineering anthocyanin biosynthesis in plants. Curr. Opin. Plant Biol. 19, 81-90. doi: 10.1016/j.pbi.2014.05.011.

Zhao, X.Q., Yuan, Z.H., Fang, Y.M., Yin, Y.L., and Feng, L.J. (2013). Characterization and evaluation of major anthocyanins in pomegranate (Punica granatum L.) peel of different cultivars and their development phases. Eur. Food Res. Technol. 236, 109-117. doi: 10.1007/s00217-012-1869-6. 


\section{SUPPORTING INFORMATION}

TABLE S1. Oligodeoxynucleotide primers used to build and analyze PVY-Ros1.

\begin{tabular}{|c|c|c|c|c|}
\hline Name & Sequence $\left(5^{\prime}-3^{\prime}\right)^{1}$ & itat & ion $^{2}$ & Use \\
\hline PI & GTTGGCAAACGCCTAAAGAT & $\mathrm{R}$ & \multirow{3}{*}{\multicolumn{2}{|c|}{$\begin{array}{l}\text { Reverse transcription of the three } \\
\text { genome fragments }\end{array}$}} \\
\hline PII & АССТTTAATTGGCAGAACGC & $\mathrm{R}$ & & \\
\hline PIII & TTTTGTCTCCTGATTGAAG & $\mathrm{R}$ & & \\
\hline PIV & $\begin{array}{l}\text { GGCGGGTCTCGGAGGAAATTAAAACAACTCAAT } \\
\text { ACAAC }\end{array}$ & $\mathrm{F}$ & \multirow{2}{*}{\multicolumn{2}{|c|}{$\begin{array}{l}\text { PCR amplification of the 5' genome } \\
\text { fragment }\end{array}$}} \\
\hline $\mathrm{PV}$ & CCGCGGTCTCCTTATTAAATCGCTCGCTCAATC & $\mathrm{R}$ & & \\
\hline PVI & GGCGGGTCTCGATAATTATTTCAATACTAAGTG & $\mathrm{F}$ & \multirow{2}{*}{\multicolumn{2}{|c|}{$\begin{array}{l}\text { PCR amplification of the central genome } \\
\text { fragment }\end{array}$}} \\
\hline PVII & CCGCGGTCTCCTTTCAGCCTACAAACTGTTTGG & $\mathrm{R}$ & & \\
\hline PVIII & GGCGGGTCTCGGAAAGTATCTGTTGAATATGGG & $\mathrm{F}$ & \multirow{2}{*}{\multicolumn{2}{|c|}{$\begin{array}{l}\text { PCR amplification of the 3' genome } \\
\text { fragment }\end{array}$}} \\
\hline PIX & $\begin{array}{l}\text { CCGCGGTCTCCTTTTGTCTCCTGATTGAAGTTT } \\
\text { ACAG }\end{array}$ & $\mathrm{R}$ & & \\
\hline PX & CCATGCACGGTACATTCAGG & $\mathrm{F}$ & \multirow{2}{*}{\multicolumn{2}{|c|}{$\begin{array}{l}\text { PCR to mutagenize the endogenous } \\
\text { Eco31I recognition site in the central } \\
\text { genome fragment (silent mutation) }\end{array}$}} \\
\hline PXI & CTGATTGAAGTTTACAGTCA & $\mathrm{R}$ & & \\
\hline PXII & CCGCGGTCTCCTTGATGGTATACTTCATAAG & $\mathrm{R}$ & \multirow{2}{*}{\multicolumn{2}{|c|}{$\begin{array}{l}\text { PCR to split between NIb and CP in the } \\
\text { third genome fragment }\end{array}$}} \\
\hline PXIII & GGCGGGTCTCGGCAAATGACACAATTGATGC & $\mathrm{F}$ & & \\
\hline PXIV & $\begin{array}{l}\text { GGCGGGTCTCGTCAAGCAAACGACATGGAAAAG } \\
\text { AATTGTCGTGG }\end{array}$ & $\mathrm{F}$ & \multirow{2}{*}{\multicolumn{2}{|c|}{$\begin{array}{l}\text { PCR amplification of Roseal flanked } \\
\text { with the sequences to complement } \\
\text { NIb/CP proteolytic cleavage }\end{array}$}} \\
\hline PXV & $\begin{array}{l}\text { CCGCGGTCTCCTTGCCTGATGATATACCTCATA } \\
\text { TGAGTCATTTCCAATTTGTTGGGCC }\end{array}$ & $\mathrm{R}$ & & \\
\hline PXVI & GCAAATGACACAATTGATGC & $\mathrm{F}$ & \multirow{2}{*}{\multicolumn{2}{|c|}{ RT-PCR diagnosis of PVY }} \\
\hline PXVII & САTGTTCTTGACTCCAAGTAG & $\mathrm{R}$ & & \\
\hline
\end{tabular}

${ }^{1}$ Eco31I recognition and cleavage sequences are on a gray background and underlined, respectively.

${ }^{2}$ Primer orientation in relation to the PVY RNA genome: forward (F) or reverse (R). 
TABLE S2. Effect of silver nanoparticles on PVY-Ros1-induced infection foci on tobacco leaves.

\begin{tabular}{|c|c|c|c|c|}
\hline \multirow[b]{2}{*}{ Plant } & \multirow[b]{2}{*}{ Leaf ${ }^{1}$} & \multicolumn{3}{|c|}{ Number of infection foci } \\
\hline & & Mock & $\begin{array}{r}100 \\
\text { ppm }\end{array}$ & $\begin{array}{l}1000 \\
\text { ppm }\end{array}$ \\
\hline \multirow{2}{*}{1} & 4 & 322 & $\overline{104}$ & 5 \\
\hline & 5 & 198 & 142 & 20 \\
\hline \multirow{2}{*}{2} & 4 & 227 & 159 & 2 \\
\hline & 5 & 181 & 150 & 20 \\
\hline \multirow{2}{*}{3} & 4 & 202 & 119 & 30 \\
\hline & 5 & 218 & 53 & 35 \\
\hline \multirow{2}{*}{4} & 4 & 138 & 100 & 26 \\
\hline & 5 & 207 & 45 & 16 \\
\hline \multirow{2}{*}{5} & 4 & 182 & 40 & 16 \\
\hline & 5 & 188 & 49 & 33 \\
\hline \multirow{2}{*}{6} & 4 & 316 & 25 & 46 \\
\hline & 5 & 422 & 55 & 20 \\
\hline
\end{tabular}

${ }^{1}$ In each plant, true leaves 4 and 5 were mechanically inoculated with PVY-Ros1.

DATASET S1. Sequence of recombinant PVY-Ros1 clone (GenBank accession number KY780083).

The start and stop codons of the main open reading frame are in green and dark red, respectively. Limits between cistrons are marked on blue background. Roseal cDNA from Antirrhinum majus is in red and flanking sequences inserted to complement the split $\mathrm{NIb} / \mathrm{CP}$ cleavage site are in blue. Mutations with respect to HM367076 are underlined.

AАATTAAAACAАCTCAATACAACATAAGAAAAACAGCGCAAAAACACTCATAAACGCTTATTCTCACTCAAGCAT CTTGCTAAGTTTCAGTTCAAATCATTTCCTTGCAATTCTCTTAAACAATATTGGAAACCATTTCAACTCAACAAG CAATCTCATCACTTCCAACCAACTTGAAATCCTCGATGGCAACTTACATGTCAACGATCTGTTTCGGTTCGTTTG AATGCAAGCTACCATACTCACCCGCCTCTTGCGGGCTTATTGTGAAGGAACGAGAAGTGCTGGCTTCCGTTAATC CTTTCGCAGATCTGGAAACACAACTTAGTGCACGATTGCTCAAGCAAGAATATGCTACTGTTCGTGTGCTCAAGA ACGGTACTTTTACGTATCGATACAAGACTGATGCCCAGATAAAGCGCATTCAGGAGAAACTGGAGAGGAAGGATA GGGAAGAATATCACTTCCAAATGGCCGCTCCTAGTATTGTGTCAAAGATTACCATAGCTGGTGGAGATCCTCCAT CAAAGTCTGAGCCACAAGCACCAAGAGGGATCATTCATACAACTCCAAGGGTGCGTAAAGTCAAGACACGCCCCA TAATAAAGTTGACAGAAGGCCAGATGAATCACCTCATTAAGCAGGTAAAGCAGATTATGTCGGAGAAGAGAGGGT CTGTCCACTTAATTAATAAGAAGACCACTCATGTTCAATATAAGGAGATACTTGGTGCAACTCGCGCAGCGGTTC 
GAACTGCACATATGATGGGTTTGCGACGGAGAGTGGACTTCCGATGTGATATGTGGACAGTTGGACTTTTGCAAC GTCTCGCTCGGACGGACAAATGGTCCAATCAAGTCCGCACTATCAACATACGAAGGGGTGATAGTGGAGTCATCT TGAACACAAAAAGCCTCAAA GGCCACTTTGGTAGAAGTTCAGGAGACTTGTTCATAGTGCGCGGATCACATGAAG GGAAATTGTACGATGCACGATCTAGAGTTACTCAGAGTGTTTTGGACTCAATGATCCAGTTTTCGAATGCTGATA ATTTTTGGAAGGGTCTGGACGGTAATTGGGCACGAATGAGATATCCTTCGGATCACACATGTGTAGCTGGTTTAC CTGTCGAAGATTGTGGTAGGGTTGCTGCATTGATGGCACACAGTATCCTCCCGTGCTATAAGATAACCTGCCCCA CCTGTGCTCAACAGTATGCCAGCTTGCCGGTTAGCGATCTGTTTAAGCTATTGCATAAACATGCAAGAGATGGTT TGAACCGATTGGGAGCAGATAAAGACCGGTTTATACATGTTAATAAGTTCTTGATAGCGTTAGAGCATCTAACTG AACCGGTGGATTTGAACCTCGAGCTTTTCAATGAGATATTTAAATCCATAGGGGAGAAGCAGCAAGCACCGTTCA AGAATTTAAATGTCTTAAATAATTTCTTCCTGAAAGGAAAAGAAAATACAGCTCATGAATGGCAGGTGGCTCAAT TGAGTTTGCTCGAATTAGCAAGGTTCCAGAAGAATAGAACTGATAACATCAAGAAGGGTGATATATCTTTCTTCA GAAATAAATTATCTGCCAAGGCAAATTGGAATCTGTATTTGTCGTGCGACAACCAATTGGACAAAAATGCAAATT TCCTGTGGGGACAAAGGGAGTATCATGCTAAGCGGTTTTTCTCAAATTTCTTTGAGGAAATTGATCCAGCAAAGG GATACTCAGCATATGAAATCCGCAAGCATCCAAATGGAACAAGGAAGCTTTCAATTGGTAACTTAGTTGTCCCAC TTGATTAGCTGAGTTAGGCAGAAGATGAAAgGTGACTATAGGAAGCAACCAGGGgTCAGCAGAAAGTGCACGA GTTCGAAAGATGGTAATTATGTGTATCCCTGTTGTTGCACAACACTTGATGATGGTTCGGCCATTGAATCAACAT TCTATCCACCAACTAAAAAGCACCTTGTAATAGGCAATAGTGGTGACCAAAAGTTTGTTGATTTACCAAAAGGGG ATTCAGAGATGTTATACATTGCCAAGCAGGGTTATTGTTATATTAACGTGTTTCTTGCAATGCTAATTAACATTA GCGAGGAGGATGCAAAGGATTTCACAAAGAAAGTCCGCGACATGTGTGTGCCGAAGCTTGGAACCTGGCCAACTA TGATGGATTTGGCGACCACTTGTGCTCAAATGAGAATATTCTATCCTGACGTGCATGATGCAGAGCTGCCTAGAA TATTGGTTGACCATGACACTCAAACGTGTCATGTGGTTGACTCATTTGGCTCGCAGACAACTGGATATCATATTC TAAAAGCATCCAGCGTGTCTCAACTTATCTTGTTTGCAAATGATGAATTAGAATCTGATATAAAACATTATAGAG TTGGTGGCGTTCCTAATGCATGCCCTGAACTTGGGTCCACGATATCACCTTTTAGAGAAGGAGGAGTTATAATGT CTGAGTCGGCAGCGCTGAAACTGCTTTTGAAGGGAATTTTTAGACCTAAGGTGATGAGACAGTTGCTGTTAGATG AGCCTTACCTGTTGATTCTATCAATATTATCCCCTGGCATACTGATGGCTATGTATAATAATGGGATTTTTGAAC TTGCGGTAAGATTGTGGATTAATGAGAAACAATCCATAGCTATGATAGCATCGCTACTATCAGCTTTAGCCCTAC GAGTGTCAGCGGCAGAAACACTCGTCGCACAGAGAATTATAATTGATGCTGCAGCTACAGACCTCCTTGATGCTA CGTGTGATGGATTCAACCTACATCTAACGTACCCCACTGCATTAATGGTATTACAAGTTGTTAAGAATAGAAATG AATGTGATGATACCCTATTCAAGGCGGGTTTTCCAAGTTACAACACGAGTGTTGTGCAGATTATGGAAAAAAATT ATCTAAGTCTCTTGGACGATGCTTGGAAAGATTTAACTTGGCGGGAAAAA TTATCCGCAACATGGTACTCATACA GAGCAAAACGCTCTATCACTCGGTACATAAAACCCACAGGAAGGGCAGATTTGAAAGGGTTATACAACATATCAC CACAAGCATTCTTGGGCCGAAGCGCCCAGGTGGTCAAAGGCACTGCCTCAGGATTGAGCGAGCGATTTAATAATT ATTTCAATACTAAGTGTGTAAATATTTCATCCTTTTTCATTCGTAGAATCTTTAGGCGTTTGCCAACTTTCGTCA CTTTTGTTAACTCATTATTAGTTATTAGTATGTTAACTAGTGTAGTGGCAGTGTGTCAGGCAATAATTTAGATC AGAGGAAGTATAGGAGAGAAATCGAGTTGATGCAGATAGAGAAGAATGAGATTGTCTGCATGGAGCTATATGCAA GTTTACAGCGCAAACTTGAACGCGATTTCACATGGGATGAGTACATTGAGTATTTGAAGTCAGTAAACCCTCAGA TAGTTCAGTTTGCTCAAGCGCAGATGGAAGAATATGATGTGCGACACCAGCGTTCCACACCAGGTGTTAAAAATT TGGAACAAGTGGTAGCATTTATGGCTTTAGTCATCATGGTGTTCGATGCTGAAAGGAGTGATTGCGTTTTCAAAA СTCTCAATAAATTTAAGGGTGTCCTTTCCTCGCTGGACCATGAAGTTCGACATCAGTCCTTAGACGATGTGATCA AGAATTTTGATGAGAGGAATGAGATTATTGATTTTGAGTTGAGTGAGGACACAATTCGAACATCATCAGTGCTAG ATACAAAGTTTAGTGATTGGTGGGACCGACAAATCCAGATGGGACATACACTTCCACATTACAGAACCGAGGGGC ACTTCATAGAATTACAAGAGCAACTGCTGTTCAAGTGGCTAATGACATTGCCCATAGTGAACACCTAGACTTTT TAGTAAGGGGAGCTGTTGGGTCTGGAAAGTCAACTGGGTTGCCTGTTCATCTTAGCGTAGCCGGATCTGTGCTTT TAATTGAACCAACGCGACCACTGGCGGAGAACGTTTTCAAACAGCTATCTAGTGAACCATTCTTCAAGAAGCCAA CACTGCGTATGCGCGGAAATAGTATATTTGGCTCTTCTCCAATCTCCGTCATGACTAGCGGATTCGCGCTACACT ACTTCGCCAATAATCGCTCCCAATTAGCTCAGTTCAACTTTGTAATATTTGATGAGTGCCATGTTCTGGATCCTT CCGCAATGGCGTTCCGCAGTCTGCTGAGTGTTTATCATCAAGCATGCAAAGTATTAAAAGTGTCAGCTACTCCAG TGGGAAGGGAGGTTGAATTCACAACACAGCAGCCAGTCAAGTTAATAGTGGAGGACACACTGTCTTTCCAATCAT TTGTTGATGCACAAGGTTCTAAAACTAATGCTGATGTTGTTCAGTTTGGTTCAAACGTACTTGTGTATGTGTCGA GCTACAATGAAGTTGATACCTTGGCTAAGCTCCTAACAGACAAGAATATGATGGTCACAAAGGTTGATGGCAGAA CAATGAAGCACGGTTGCCTAGAAATTGTCACAAAAGGAACCAGTGCGAGGCCACATTTTGTTGTAGCAACCAACA TAATTGAAAATGGAGTGACTTTGGACATAGACGCGGTTGTGGATTTTGGGTTGAAAGTCTCACCATTCTTGGACA TTGACAATAGGAGCATTGCCTACAATAAGGTGAGTATTAGCTATGGTGAAAGAATTCAAAGGTTGGGTCGTGTTG GACGCTTCAAGAAAGGAGTAGCATTGCGCATTGGACACACTGAGAAGGGAATTATTGAAATTCCAAGCATGGTTG CTACTGAGGCGGCTCTTGCTTGCTTTGCATATAACTTGCCAGTGATGACAGGCGGCGTCTCAACTAGTCTGATTG GCAATTGTACTGTGCGCCAGGTTAAAACAATACAGCAATTTGAATTGAGTCCATTCTTTATCCAGAATTTCGTTG CTCATGATGGATCAATGCATCCTGTCATACATGACATTCTTAAAAAGTATAAACTGCGAGATTGTATGACACCTT 
TGTGCGATCAGTCTATACCATACAGGGCATCGAGCACTTGGTTATCGGTTAGTGAATATGAGCGACTTGGAGTGG CCTTAGAAATTCCAAAGCAAGTCAAAATTGCATTCCATATCAAAGAGATCCCTCCTAAGCTCCACGAAATGCTTT GGGAAACGGTTGTCAAATACAAAGACGTTTGCTTATTTCCAAGCATTCGAGCATCGTCCATCAGCAAAATCGCAT ACACATTGCGTACAGACCTCTTCGCCATCCCAAGGACTCTAATATTGGTGGAGAGATTACTTGAAGAGGAGCGAG TGAAGCAGAGCCAATTCAGAAGTCTCATCGATGAAGGGTGCTCAAGTATGTTTTCAATTGTTAACTTGACCAACA CTCTCAGAGCCAGATATGCAAAAGATTACACCGCAGAGAACATACAAAAACTTGAGAAAGTGAGAAGTCAATTGA AAGAATTCTCAAATCTGGATGGTTCTGCATGTGAGGAGAATTTAATAAAGAGGTATGAGTCTTTGCAGTTCGTTC ATCACCAAGCTGCAACGTCACTTGCAAAGGATCTCAAGTTGAAGGGGACCTGGAAGAAATCATTAGTGGCTAAAG ACTTGATCATAGCAGGCGCTGTTGCAATTGGTGGTATAGGACTCATATATAGTTGGTTCACACAATCAGTTGAGA CTGTGTCCCATCAAGGGAAAAATAAATCCAAAAGAATCCAAGCCTTGAAGTTTCGCCATGCTCGTGACAAAAGGG CTGGCTTTGAAATTGACAGCAATGATGACACAATAGAGGAATTCTTTGGATCTGCATATAGGAAAAAGGGAAAAG GTAAAGGTACCACAGTCGGTATGGGCAAGTCAAGCAGGAAGTTCATCAACATGTATGGGTTTGATCCAACAGAGT ACTCATTCATCCAGTTCGTTGATCCACTCACTGGGGCGCAAATAGAAGAGAATGTCTATGCTGACATTAGAGACA TTCAAGATAGATTAGTGAAGTGCGAAAGAAAATGGTTGAGAATGATGACATTGAAATGCAAGCCTTGAGTAGTA ACACAACCATACATGCATACTTCAGGAAAGATTGGTCTGACAAAGCTTTGAAGATTGACTTAATGCCACACAACC CACTCAAAGTCTGTGACAAAACAAATGGCATTGCAAAATTTCCTGAGAGA GAGCTCGAACTAAGGCAGACTGGAC CAGCTGTAGAAGTCAATGTGCAGGACATACCAGCACAGGAGGTGGAGCATGAAGCTAAATCGCTCATGAGAGGTT TGAGAGACTTCAACCCAATCGCCCAAACAGTTTGTAGGCTGAAAGTATCTGTTGAATATGGGACATCAGAGATGT ACGGTTTTGGATTTGGAGCATACATAATAGCGAACCACCATTTGTTTAGGAGTTACAATGGTTCCATGGAGGTGC GATCCATGCACGGTACATTCAGGGTGAAGAATCTACACAGTTTGAGCGTTCTGCCAATCAAAGGTAGGGACATAA TCCTCATAAAAATGCCGAAGGATTTCCTGTCTTTCCACAGAAATTGCATTTCCGAGCTCCTATACAGAATGAAA GAGTTTGTTTAGTTGGGACCAACTTTCAGGAGAAGTATGCATCGTCAATCATCACAGAAACAAGCACTACTTACA ATATACCAGGTAGCACATTCTGGAAGCATTGGATTGAAACAGACAATGGACATTGTGGACTACCAGTGGTAAGCA CTGCCGATGGATGTCTAGTCGGAATTCACAGTTTGGCAAACAATGCACACACCACGAATTACTACTCAGCCTTCG ATGAGGATTTTGAAAGCAAGTACCTCCGGACCAATGAGCACAATGAATGGGTCAAGTCTTGGAAATATAATCCAG ACACAGTGTTGTGGGGCCCGTTGAAACTTAAAGACAGCACTCCCAAAGGGTTATTTAAAACAACAAAGCTTGTGC AAGATCTAATCGAGCATGATGTAGTGGTGGAGCAAGCTAAGCACTCTGCGTGGATGTTTGAAGCCTTGACAGGAA ATTTGCAAGCTGTCGCAACAATGAAGAGCCAATTAGTAACCAAGCATGTAGTTAAAGGAGAGTGTCGACACTTCA AGGAGTTCCTGACTGTGGATGCAGAAGCAGAGGCATTCTTCAGGCCTTTGATGGATGCGTATGGGAAAAGCTTGC TGAACAGAGATGCGTACATCAAGGACATAATGAAGTATTCAAAACCTATAGATGTTGGTATCGTGAATTGTGATG CATTCGGAGGAGCCATCAATAGGGTTATCATCTACCTGCAAGTGCACGGCTTCCAGAAGTGTACATATGTCACTG ACGAG GAAGAAATTTTCAAAGCGCTTAACATGAAAGCTGCAGTCGGAGCCATGTATGGTGGCĀAAAAGAAAGACT ATTTTGAGCATTTCACTGATGCAGACAAGGAAGAAATAGTCATGCAAAGCTGTCTGCGATTGTATAAAGGCTTGC TCGGCATTTGGAATGGATCATTGAAGGCAGAGCTCCGGTGCAAGGAAAAGATACTTGCAAATAAGACGAGGACAT TCACTGCTGCACCTCTAGACACTTTGCTGGGTGGTAAAGTGTGTGTTGACGACTTCAATAATCAATTTTATTCAA AGAATATTGATGCTGTTGGACAGTTGGGATGACTAAGTTTTATGGTGGTTGGGATAAACTGCTTCGGCGTTTAC CTGAGAATTGGTATACTGTGATGCTGATGGCTCACAGTTTGATAGTTCACTAACTCCATACTTAATCAATGCTG TTCTCACCATCAGAAGCACATACATGGAAGACTGGGATGTGGGGCTGCAAATGCTGCGTAATTTATACACTGAGA TTGTTTACACACCTATTTCAACTCCAGATGGAACAATTGTTAAGAAGTTCAGAGGAAATAACAGTGGTCAGCCTT CTACTGTTGTGGACAACTCTCTTATGGTCGTCCTTGCCATGCACTATGCTTTCATCAGAGAAGGCATTGAGTTTG AAGAAACTGACAGCACGTGCGTGTTCTTTGTTAATGGTGATGATTTGCTGATTGCTGTGAATCCGGATAAAGAGG ACATTCTTGACAGATTGTCACAACACTTCTCAGATCTTGGCTTAAATTATGATTTCTCGTCAAGAACAAGAAATA AGGAAGAGTTGTGGTTATGTCTCATAGGGGCCTACTGATTGAGGGCATGTACGTGCCGAAACTTGAAGAAGAAA GGATTGTGTCCATTCTCCAATGGGACAGAGCAGACTTGGCTGAACACAGGCTTGAGGCGATTTGCGCAGCTATGA TAGAGTCCTGGGGTTATTCTGAACTAACACACCAAATCAGGAGATTCTACTCATGGTTATTGCAACAGCAACCTT TTGCAACAATAGCGCAGGAGGGGAAGGCTCCTTATATAGCAAGCATGGCATTAAGGAAACTGTATATGGATAGGG CTGTGGATGAGGAAGAGCTTAGAGCCTTCACTGAAATGATGGTCGCATTAGACGATGAGTTTGAGTTTGACTCTT ATGAAGTATACCATCAAGCAAACGACATGGAAAAGAATTGTCGTGGAGTGAGAAAAGGTACTTGGACCAAAGAAG AAGACACTCTCTTGAGGCAATGTATAGAAGAGTATGGTGAAGGGAAATGGCATCAAGTTCCACACAGAGCAGGGT TGAACCGGTGTAGGAAGAGTTGCAGGCTGAGGTGGTTGAATTATCTGAGGCCAAATATCAAAAGAGGTCGGTTTT CGAGAGATGAAGTGGACCTAATTGTGAGGCTTCATAAGCTGTTGGGTAACAAATGGTCGCTGATTGCTGGTAGAA TTCCTGGAAGGACAGCTAATGACGTGAAGAACTTTTGGAATACTCATGTGGGGAAGAATTTAGGCGAGGATGGAG AACGATGCCGGAAAAATGTTATGAACACAAAAACCATTAAGCTGACTAATATCGTAAGACCCCGAGCTCGGACCT TCACCGGATTGCACGTTACTTGGCCGAGAGAAGTCGGAAAAACCGATGAATTTTCAAATGTCCGGTTAACAACTG ATGAGATTCCAGATTGTGAGAAGCAAACGCAATTTTACAATGATGTTGCGTCGCCACAAGATGAAGTTGAAGACT GCATTCAGTGGTGGAGTAAGTTGCTAGAAACAACGGAGGATGGGGAATTAGGAAACCTATTCGAGGAGGCCCAAC AAATTGGAAATGACTCATATGAGGTATATCATCAGGCAAATGACACAATTGATGCAGGAGGAAGCAACAAGAAAG 


\section{Capítulo II}

ATACAAAACCAGAGCAAAGCAGCATCCAGTCAAACCCGAACAAAGGAAAAGATAAAGATGTGAATGCCGGCACAT CTGGGACACACACTGTACCGAGAATCAAGGCTATCACGTCCAAAATGAGAATGCCCAAAAGCAAGGGAGCAGCTG TGCTGAATTTAGAACACTTGCTTGAGTATGCTCCACAACAAATTGATATTTCAAATACTCGGGCAACTCAATCAC AGTTTGATACGTGGTATGAAGCAGTGCGGATGGCATACGACATAGGAGAAACTGAGATGCCAACTGTGATGAATG GGCTTATGGTTTGGTGCATTGAAAATGGAACCTCGCCAAATGTCAACGGAGTTTGGGTTATGATGGATGGGAATG AACAAGTTGAGTACCCGTTGAAACCAATCGTTGAGAATGCAAAACCAACCCTTAGGCAAATCATGGCACATTTCT CAGATGTTGCAGAAGCGTATATAGAAATGCGCAACAAAAAGGAACCATATATGCCACGATATGGTTTAATTCGAA ATCTGCGGGATATGGGTTTAGCGCGTTATGCTTTTGACTTTTATGAGGTCACATCACGAACACCAGTGAGGGCTA GGGAAGCGCAAATTCAAATGAAGGCCGCAGCATTGAAATCAGCTCAACCTCGACTTTTCGGGTTGGACGGTGGCA TCAGTACACAAGAGGAGAACACAGAGAGGCACACCACCGAGGATGTCTCTCCAAGTATGCATACTCTACTTGGAG TCAAGAACATGTGATGTAGTGTCTCTCCGGACGATATATAAATATTTACATATGCAGTAAGTATTTTGGCTTTTC CTGTACTACTTTTATCATAATTAATAATCAGTTTGAATATTACTAATAGATAGAGGTGGCAGGGTGATTTCGTCA TTGTGGTGACTCTATCTGTTAATTTCGCATTATTAAGTCTTAGATAAAAGTGCCGGGTTGTCGTTGTTGTGGATG ATTCATCGATTAGGTGATGTTGCGATTCTGTCGTAGCAGTGACTATGTCTGGATCTATCTGCTTGGGTGGTGTTG TGATTTTGTCATAACAGTGACTGTAAACTTCAATCAGGAGAC 
CAPÍTULO III 



\section{Boolean computation in plants using post-translational genetic control and a visual output signal}

Teresa Cordero $^{1}$, Arantxa Rosado $^{1,2}$, Eszter Majer ${ }^{1}$, Alfonso Jaramillo ${ }^{2,3,4}$, Guillermo Rodrigo $^{1,2}$, and José-Antonio Daròs*,1

${ }^{1}$ Instituto de Biología Molecular y Celular de Plantas, CSIC-Universitat Politècnica de València, 46022 Valencia, Spain

${ }^{2}$ Institute for Integrative Systems Biology, Universitat de València-CSIC, 46980 Paterna, Spain

${ }^{3}$ Warwick Integrative Synthetic Biology Centre and School of Life Sciences, University of Warwick, Coventry, CV4 7AL, UK

${ }^{4}$ Institute of Systems and Synthetic Biology, Université d'Évry Val d'Essonne-CNRS, F91000 Évry, France 


\section{ABSTRACT}

Due to autotrophic growing capacity and extremely rich secondary metabolism, plants should be preferred targets of synthetic biology. However, developments in plants usually run below those in other taxonomic groups. In this work we engineered genetic circuits able of logic YES, OR and AND Boolean computation in plant tissues with a visual output signal. The circuits, which are deployed by means of Agrobacterium tumefaciens, perform with the conditional activity of the MYB transcription factor Roseal from Antirrhinum majus inducing the accumulation of anthocyanins, plant endogenous pigments that are directly visible to the naked eye or accurately quantifiable by spectrophotometric analysis. The translational fusion of Rosea1 to several viral proteins, such as potyvirus NIb or fragments thereof, rendered the transcription factor inactive. However, anthocyanin accumulation could be restored by inserting protease cleavage sites between both moieties of the fusion and by co-expressing specific proteases, such as potyvirus nuclear inclusion $a$ protease.

\section{RESEARCH ARTICLE}

Plants should be the preferred targets for synthetic biology as they allow the cheap, easy and safe production of many natural compounds of much interest, ${ }^{1}$ due to properties such as autotrophic growing capacity and extremely rich secondary metabolism. ${ }^{2}$ They can also foster the development of novel biosensors ${ }^{3}$ and sustainable interfaces of communication, by exploiting their ability to reshape their physiology and to express heterologous genes. ${ }^{4}$ However, synthetic biology approaches in plants usually run below those in other taxonomic groups, where remarkable examples of logic programs of gene expression exist. ${ }^{5,6}$

The field of synthetic biology has vastly grown in recent years. ${ }^{7}$ Advances have been essentially made on two fronts: foundational and applied synthetic biology. On the one hand, the foundations about the engineering of novel synthetic systems (or the re-engineering of natural ones) have advanced thanks to novel regulatory mechanisms, such as those based on non-coding RNAs $^{8-10}$ or membrane receptor proteins, ${ }^{11,12}$ fully synthetic functional circuits designed according to rational premises, such as bistables ${ }^{13,14}$ or oscillators, ${ }^{15,16}$ and novel physicochemical models capable of mapping sequence with function. ${ }^{17-19}$ On the other hand, and in parallel to these achievements, some natural systems have been re-engineered to set up new functions in cells to solve applied problems, such as, with plants, the $\beta$-carotene production 
in rice through metabolic rerouting ${ }^{20}$ or the detection of explosives with a synthetic signal transduction pathway. ${ }^{3}$ To enhance the designability and sophistication of these solutions, more work on the basic mechanisms and circuitries of gene expression control is required. However, we are still quite far from reaching this point in plants, ${ }^{21}$ as most of the aforementioned foundational achievements have been accomplished in bacteria, along with some notable achievements made in yeast and mammalian cells. ${ }^{5}$

The present work aimed to create a regulatory system in plants with the following premises. First, the system would be based on a mechanism of post-translational genetic control, as some previous developments in plants have focused on synthetic transcription regulation, ${ }^{22}$ able to reliably work in different contexts and in a modular fashion. Second, the regulatory mechanism would be specified at the nucleotide level. Third, the output signal would be monitored visually by exploiting the rich secondary metabolism of plants for tissue pigmentation. Then fourth, the genetic system would be encapsulated in agrobacteria to allow the rapid deployment of the engineered circuitry in the plant and avoiding the tedious process of plant stable genetic transformation.

We exploited plant viruses (potyviruses in particular) as a source of genetic material, as pioneers in synthetic biology did with bacteriophages. ${ }^{16}$ Genus Potyvirus comprises the largest group of plus-strand RNA viruses that infect plants. ${ }^{23}$ One of their most distinctive properties is their gene expression strategy, which is based on a regulated cascade of proteolytic processing by three virus-encoded proteases to render individual viral proteins from a large polyprotein. ${ }^{23,24} \mathrm{P} 1$ protease and helper-component protease (HC-Pro), the two most aminoterminal products of the viral polyprotein, self-cleave from the precursor, while the rest of proteolytic processing depends on the activity of nuclear inclusion $a$ (NIa) protein, a protease that exquisitely recognizes a seven-amino-acid motif $(-6 /+1)$ that surrounds the different cleavage sites. ${ }^{25}$ The exact amino-acid composition of the various cleavage sites in the viral polyprotein determines the cleavage efficiency, which is the basis of the regulated processing cascade. ${ }^{26} \mathrm{NIa}$ is, in turn, a polyprotein that undergoes self-cleavage at an internal cleavage site that inefficiently splits two domains, VPg and NIaPro, the latter of which is the protease domain itself. Both are multifunctional proteins involved in interactions with a large number of host proteins during infection. ${ }^{27}$ The exact specificity toward the substrate and efficient catalytic activity under broad conditions have converted NIaPro, particularly that from Tobacco etch virus (TEV, genus Potyvirus), into the workhorse of many biotechnological applications. ${ }^{28}$ Here 
we took advantage of the exquisite specificity of different potyviral NIaPros to implement genetic circuits capable of performing basic logic computations in plants. For the output signal, we considered anthocyanins, plant-endogenous pigments that are readily visible to the naked human eye. ${ }^{29,30}$ In turn, such pigmentation can be accurately quantified in a spectrophotometer by measuring absorbance after simple extraction from plant tissues.

\section{RESULTS AND DISCUSSION}

\section{The master regulator of the anthocyanin pathway is inactive when it is translationally} fused to selected proteins or protein fragments.

We have previously shown that potyvirus replication and movement through the plant, and those of other viruses that belong to different taxonomic groups, can be visually tracked through the virus-mediated expression of MYB R2R3-type transcription factor Rosea1 from snapdragon (Antirrhinum majus L.). ${ }^{31-35}$ When expressed in plant cells, Roseal activates the production of companion regulatory proteins to form a ternary complex that induces the transcription of anthocyanin biosynthetic genes. ${ }^{29,36}$ Thus, we wondered whether the anthocyanin accumulation induced by Rosea1 activity would also be possible if this transcription factor was translationally fused to a viral protein. This design would be simpler, and consequently more applicable, to different plant virus families than a design based on the expression of a free protein as viral genomes are highly constrained. ${ }^{37}$

To answer this question, we constructed three TEV recombinant clones in which A. majus Rosea1 complementary DNA (cDNA) was fused at the 5' end of P1, HC-Pro, and nuclear inclusion $b(\mathrm{NIb}$, the viral RNA-dependent RNA polymerase) cistrons (TEV-Ros1P1, TEVRos1HCPro and TEV-Ros1NIb, respectively, Figure 1A). Figure S1 in Supplementary Information (SI) schematizes these constructs. See the precise nucleotide sequences in SI Figure S2. A few amino acids at the amino termini of HC-Pro and NIb were duplicated to ensure efficient proteolytic processing. Tobacco (Nicotiana tabacum L.) plants were inoculated with the three recombinant TEV clones using Agrobacteriun tumefaciens GV3101 to induce systemic virus infection. A TEV-Ros1 clone, in which Roseal cDNA was inserted between cistrons NIb and CP, flanked by artificial NIaPro cleavage sites to release the transcription factor as a free element during polyprotein processing, was used as the positive control (SI Figures S1 and S2). ${ }^{31}$ At 5 days post-inoculation (dpi), all the plants inoculated with TEV-Ros1 started to show infection symptoms. Symptomatic tissues soon ( $7 \mathrm{dpi}$ ) became pigmented in a 
reddish color, as previously observed. ${ }^{31}$ With the viral clones in which Rosea1 was translationally fused, infection symptoms also appeared in all the plants inoculated with TEVRos1NIb and TEV-Ros1P1, but with some delay (about 10 and 18 dpi, respectively). However, the symptomatic tissues of these plants never appeared to be pigmented (Figure 1B). The plants inoculated with TEV-Ros1HCPro did not show any symptoms after one month of observation.
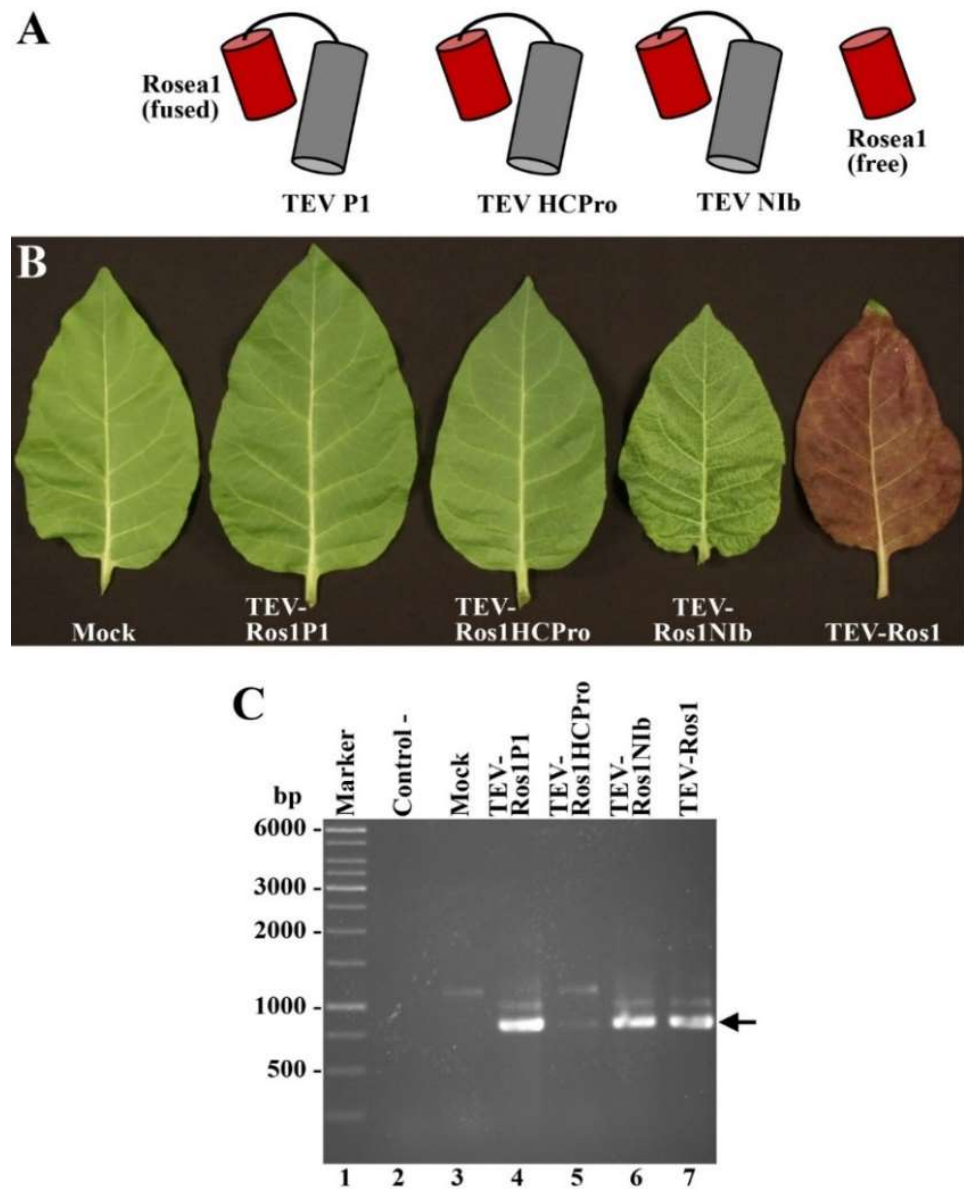

Figure. 1. Plant inoculation with TEV recombinant clones in which the Rosea1 transcription factor was fused to different viral proteins. (A) Schematic representation of the different Rosea1 fusions. (B) Representative systemic leaves of tobacco plants mock-inoculated or inoculated with TEV-Ros1P1, TEV-Ros1HCPro, TEV-Ros1NIb and TEV-Ros1, as indicated. Pictures were taken at 11 dpi. (C) RT-PCR TEV diagnosis of systemic tissue from tobacco plants inoculated with recombinant TEV clones. PCR products were separated by electrophoresis in an agarose gel that was stained with ethidium bromide. Lane 0, DNA marker ladder with the size of some molecules on the left in bp; lane 1, RT-PCR negative control with no added RNA; lanes 3 to 7, RT-PCR products from systemic tissues of plants mock-inoculated and inoculated with TEV-Ros1P1, TEV-Ros1HCPro, TEV-Ros1NIb and TEV-Ros1, respectively. The arrow points out the expected band in infected tissues that corresponds to TEV coat protein cDNA.

The reverse transcription (RT)-polymerase chain reaction (PCR) amplification of the TEV CP cistron from the RNA preparations from inoculated plants confirmed infection with TEV-Ros1, 
TEV-Ros1P1 and TEV-Ros1NIb, and also showed asymptomatic infection for TEVRos1HCPro (Figure 1C). Tissue samples for this analysis were taken at a late time postinoculation (30 dpi) to avoid overlooking slow, low titer infections. These results indicate that Rosea1 is a transcription factor that becomes tightly inactive when translationally fused to some viral proteins, which opens up novel mechanisms for engineering genetic circuits in plants if Rosea1 is able to be released in a controlled manner.

\section{NIaPro can control the activity of Rosea1 at the post-translational level.}

The observation that Roseal becomes inactive when fused to some viral proteins led us to envision a synthetic system in which NIaPro expression would control the activity of Roseal at the post-translational level, provided that an appropriate cleavage site is inserted between this transcription factor and the inhibiting moiety. To build such a synthetic system, we started exploring the Rosea1-NIb fusion because TEV-Ros1NIb was the recombinant virus with the shortest delay in infection. In addition, to avoid any potential interference with TEV NIaPro due to unintended binding - TEV NIa and NIb interact each other $-{ }^{38}$, we used a NIb homolog from a phylogenetically distant potyvirus, ${ }^{39}$ i.e. Watermelon mosaic virus (WMV) (Figure 2A). We designed a construct to express a Roseal-NIb fusion in which the two moieties were separated by a TEV NIaPro cleavage site (Ros1-tev-NIb). We chose the $-8 /+3$ codons surrounding the $\mathrm{NIb} / \mathrm{CP}$ processing site in $\mathrm{TEV}$ due to a previous observation of highly efficient cleavage by TEV NIaPro in plants. ${ }^{40}$ The co-expression of the fusion protein and TEV NIaPro in plant tissues were mediated by the Cauliflower mosaic virus (CaMV) 35S promoter and terminator, and modified 5' and 3' untranslated regions from Cowpea mosaic virus (CPMV) RNA-2 ${ }^{41}$ (nucleotide sequences in SI Figures S3 and S4). These expression cassettes were inserted between the transfer DNA borders of a binary plasmid for the A. tumefaciens-mediated expression in Nicotiana benthamiana Domin. tissues (SI Figure S5). We chose this plant species because of facility in transient expression assays. When the Rosea1-tev-NIb fusion was co-expressed with TEV NIaPro in $N$. benthamiana leaves, the infiltrated tissue started to turn red at 3 dpi and maintained pigmentation for 2 weeks until the tissue senesced, unlike when the reporter fusion was expressed alone. A picture of a representative leaf at 5 dpi is shown in Figure 2B. From the infiltrated tissues collected at 6 dpi, we extracted anthocyanins and quantified the red pigments at $535 \mathrm{~nm}$ by spectrophotometric measurements, revealing a statistically significant dynamic range in color enrichment (Figure 2C). We set 0.2 in absorbance as the threshold to identify $\mathrm{OFF} / \mathrm{ON}$ states. These results support the design principle followed herein, and reveal a system that may be used to acquire information from 
the plant molecular world with the naked eye if NIaPro is placed under the control of a suitable promoter.

Since NIb is a large protein $(59.4 \mathrm{kDa})$, we wondered whether we could delete fragments of it without this affecting the performance of the regulatory system. We prepared several versions of the Ros1-tev-NIb construct with successive deletions of the NIb moiety from the carboxyl terminus (Figure 3A, nucleotide sequences in SI Figure S3). Then we assayed anthocyanin accumulation in $N$. benthamiana leaves by co-expressing these constructs with TEV NIaPro (Figure 3B). The NIb deleted forms that consisted of the 300, 200, and 100 amino-terminal amino acids of the polymerase prevented Roseal activity, which was efficiently restored upon the co-expression of TEV NIaPro. In contrast, the deleted forms that consisted of the 50 and 25 amino-terminal amino acids of NIb were not sufficient to inhibit Roseal activity (Figure 3C). In view of these results, we chose the 100 amino-terminal amino acids of WMV NIb $\left(\mathrm{NIb}_{100}\right)$ to conduct further work.
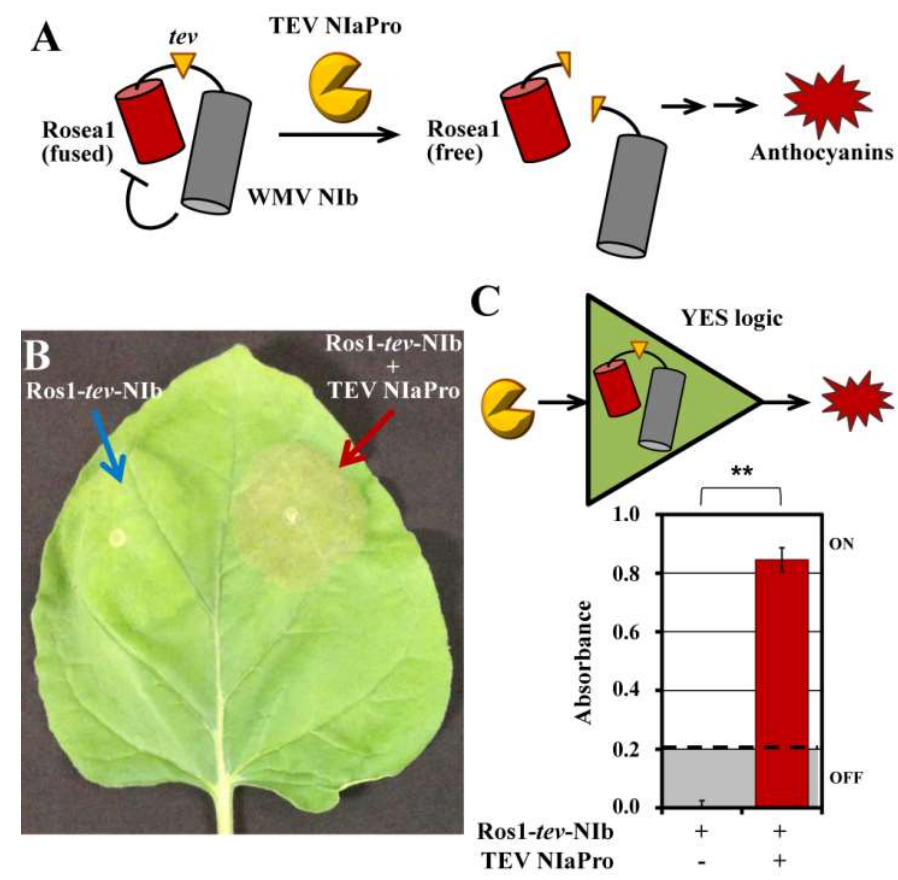

Figure 2. NIaPro-based proteolytic activation of Rosea1. (A) Schematic representation of the proteolytic reaction in which TEV NIaPro cleaves the inactive fusion reporter construct Ros1-tev-NIb releasing the Rosea1 transcription factor that activates pigmented anthocyanin biosynthesis. (B) Representative picture of an $N$. benthamiana leaf infiltrated with $A$. tumefaciens to express the NIb-tev-Ros1 reporter (left) or the reporter plus TEV NIaPro (right). Picture was taken at 5 dpi. (C) Graphic representation of the absorbance in N. benthamiana tissues infiltrated with A. tumefaciens to express the NIb-tev-Ros1 reporter alone or with TEV NIaPro. Tissues from three independent plants were collected at $6 \mathrm{dpi}$, anthocyanins were extracted and the absorbance at $535 \mathrm{~nm}$ was measured. Error bars represent the standard error of the mean. ${ }^{* *} P \leq 0.01$ (one-tailed, heteroscedastic $t$-test). 
Next, we explored the possibility of using proteases from other potyviruses, expanding this way the available elements for genetic engineering. To this end, we made two parallel constructs: one to express Tobacco vein mottle virus (TVMV, genus Potyvirus) NIaPro, a homologous protease that recognizes a different cleavage motif; ${ }^{42}$ another to express a modified version of the reporter in which the $-8 /+3$ TEV NIaPro cleavage site was replaced with the corresponding site associated with TVMV NIaPro (Ros1-tvmv-NIb ${ }_{100}$; Figure 3D; nucleotide sequences in SI Figures S3 and S4). Once again, we chose the amino acids surrounding the NIb/CP cleavage site in this new virus. This system was also significantly responsive (statistically) to the expression of that NIaPro, although with lower dynamic range in color enrichment (TEV NIaPro led to absorbance $\sim 1$, while TVMV NIaPro to $\sim 0.5$ ). Note the different scales of the $y$ axis in Figure 3D. We also found that the two proteases did not show cross-reactivity (with statistical significance) in the co-expression experiments of the non-cognate pairs (Figure 3D).

\section{Genetic circuits able of basic Boolean computation in plants with a visual output signal.}

Finally, we investigated whether this regulatory strategy would be amenable for basic Boolean computation in plants. We focused on two-input logic gates using TEV and TVMV NIaPros. On the one hand, we aimed at engineering an OR logic gate. To this end, we designed a new system in which the cDNA of the transcription factor was separated from the cDNA of the NIbderived inhibitory fragment by two contiguous protease-cleaving domains (Ros1-tvmv-tev$\mathrm{NIb}_{100}$; Figure 4A, nucleotide sequence in SI Figure S3); one corresponded to TVMV NIaPro and the other to TEV NIaPro. In this way, each protease could independently release the transcription factor. When assayed in plants, we found that both proteases indeed produced tissue pigmentation (Figure 4B). However, we noticed asymmetric color enrichment, expected by the fact that TEV NIaPro is more efficient than TVMV NIaPro. In addition, while TEV protease indeed led to a statistically significant dynamic range, the boost induced by TVMV protease was marginally non-significant, despite the mean absorbance was above 0.2. In this regard, our system would be benefited by the development of new proteases with enhanced activity.

On the other hand, we aimed at engineering an AND logic gate. In order to do this, we flanked the Rosea1 cDNA, both upstream and downstream, by two NIb-derived inhibitory fragments, each of which was separated by three copies of specific NIaPro cleavage sites $\left(\mathrm{NIb}_{100}-3 \times t e v-\right.$ Ros1-3×tvmv-NIb 100 ; Figure 5A; SI Figure S3). Three copies of the cleavage sites were used 
to increase the efficiency of Roseal release. We had previously assayed a construct that only had one site per flank $\left(\mathrm{NIb}_{100}-t e v\right.$-Ros1-tvmv-NIb $\left.{ }_{100}\right)$, obtaining unsatisfactory results.
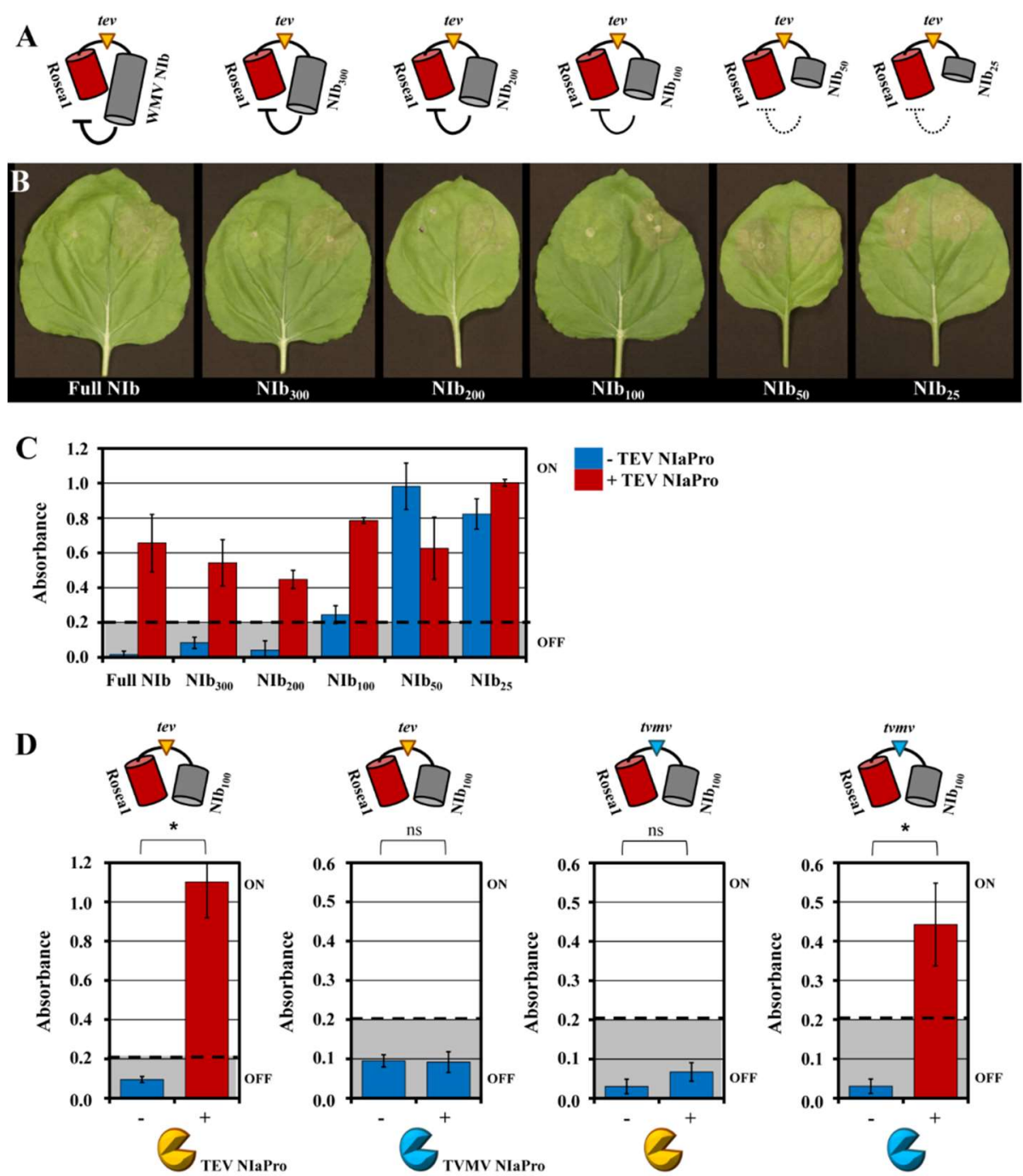

Figure 3. Inhibition of Roseal activity by WMV NIb fragments. (A) Schematic representation of the different Ros1-tev-NIb reporter constructs with increasing NIb deletions. NIb subscript indicates the remaining amino terminal amino acids in the WMV NIb deleted forms. (B) Representative pictures of $N$. benthamiana leaves infiltrated with A. tumefaciens to express different forms of the Ros1-tev-NIb reporter with the full WMV NIb or amino terminal fragments, as indicated in number of amino acids. On each leaf, the reporter was infiltrated alone on the left and with TEV NIaPro on the right. Pictures were taken at 5 dpi. (C) Graphic representation of the absorbance in $N$. benthamiana tissues infiltrated with A. tumefaciens to express the different Ros1-tev-NIb reporters, as indicated, either alone (blue bars) or with TEV NIaPro (red bars). (D) Graphic representation of the absorbance in $N$. benthamiana tissues infiltrated with A. tumefaciens to express the Ros1-tev-NIb or Ros1-tvmvNIb reporters, as indicated, either alone (blue bars) or with TEV NIaPro or TVMV NIaPro, as indicated (red bars). (C and D) Tissues from three independent plants were collected at $6 \mathrm{dpi}$, anthocyanins were extracted and the absorbance at $535 \mathrm{~nm}$ was measured. Error bars represent the standard error of the mean. $(\boldsymbol{D}){ }^{*} P \leq 0.05$ (one-tailed, heteroscedastic $t$-test); ns: non-significant $(P>0.1)$. 
Accordingly, we expected the transcription factor to be released only in presence of the two proteases. The co-expression of this new reporter construct with either TEV or TVMV NIaPros did not produce statistically significant anthocyanin accumulation, and even the mean absorbance was below the threshold set. However, the co-expression with both proteases (SI Figure S4) at the same time produced statistically significant color enrichment (Figure 5B). In this case of cooperation, the dynamic range was limited by the protease with lower activity (TVMV NIaPro).
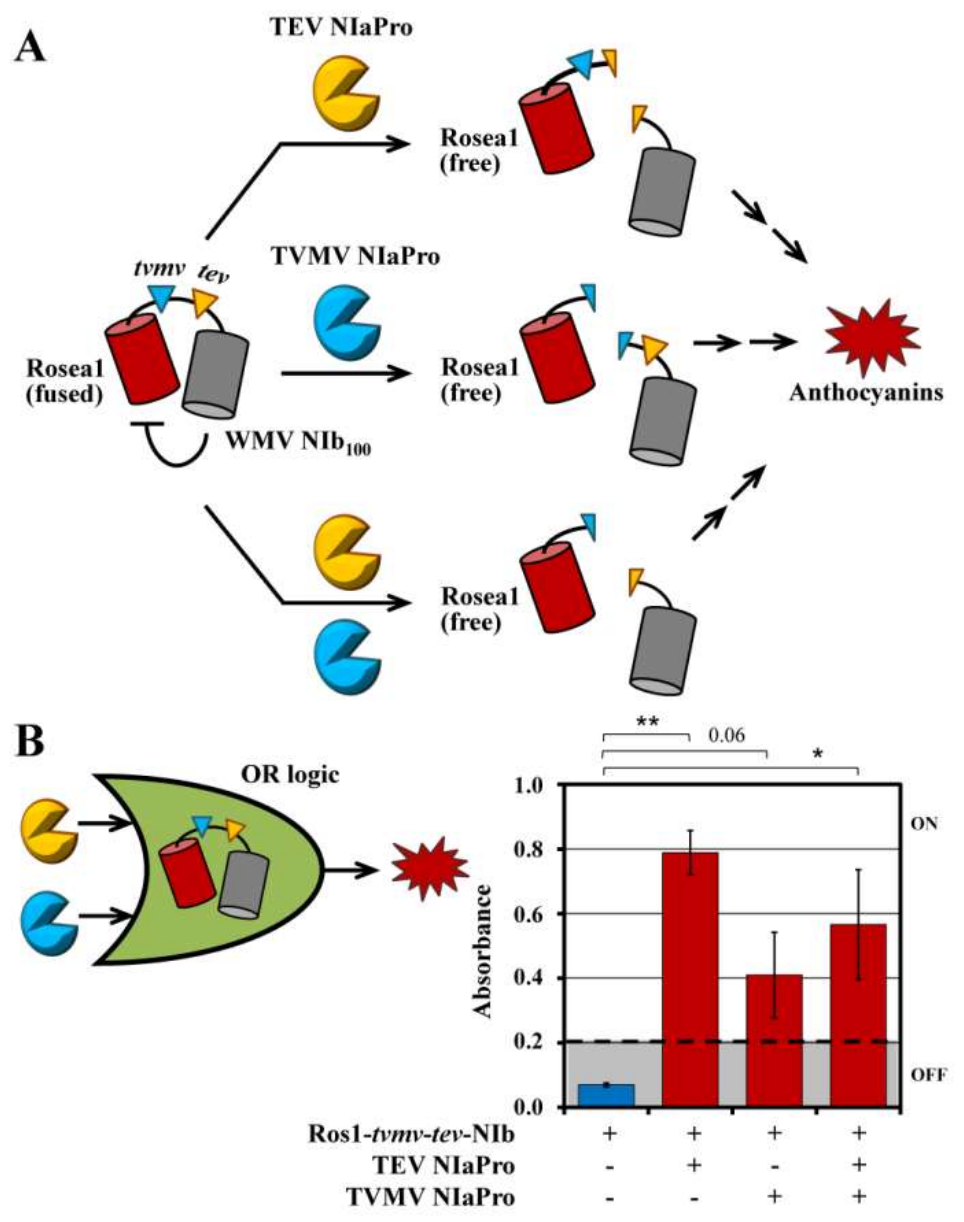

Figure 4. Synthetic circuit capable of performing Boolean OR computation in plants with visual output. Schematic representation of the reactions in which the reporter construct Ros1-tvmv-tev-NIb${ }_{100}$ responds activating the accumulation of pigmented anthocyanins in the presence of TEV NIaPro or TVMV NIaPro (OR logic gate) (B) Graphic representation of the absorbance in $N$. benthamiana tissues infiltrated with $A$. tumefaciens to express the reporter construct Ros1-tvmv-tev-NIb 100 alone (blue bars) or with TEV and TVMV NIaPros as indicated (red bars). Tissues from three independent plants were collected at 6 dpi and anthocyanins were quantified at $535 \mathrm{~nm}$. Error bars represent the standard error of the mean. ${ }^{*} P \leq 0.05$ and ${ }^{* *} P \leq 0.01$ (one-tailed, heteroscedastic $t$-test); 0.06 : marginally non-significant $(P=0.06)$. 


\section{Perspectives on synthetic genetic circuits deployed in plant tissues through agrobacteria.}

The results herein show that increasingly sophisticated gene expression programs can be implemented into plants by gathering distinct genetic elements with reliable properties; in this case, sequence-specific viral proteases (potyviral NIaPros) and a metabolic regulator (transcription factor Rosea1). Notably, circuits that exploit these proteases have been recently developed in bacteria. ${ }^{43,44}$ The successful engineering (rational design, genetic implementation and accurate characterization) of synthetic circuitries that lead to such programs promises the engineering of novel organisms with improved or added functionalities that would be profitable in biotechnological or biomedical applications with increasing sophistication. ${ }^{45}$ Our aim in this work was to deploy the synthetic circuits in plant tissues using the natural gene transfer capabilities of $A$. tumefaciens. ${ }^{46}$ In contrast to the time-consuming process of plant transformation, A. tumefaciens can be rapid and efficiently transformed. In addition, once an engineered A. tumefaciens clone is constructed, the synthetic elements it bears can be expressed alone or in combination with other elements expressed by the plant or different $A$. tumefaciens clones in a week time scale and in a limited portion of the plant.

This work represents, in our view, a step toward the engineering of logic circuits in plants, ${ }^{21}$ where the different logic gates that we created herein will provide the building blocks to rationally construct larger circuits. As we implemented the Boolean operations through irreversible post-translational events, transcriptional regulation remains to couple these logic gates with environmental or cellular signals. The relevance of our development is in the use of a visual output signal, which opens the door to test synthetic biology prototypes in the field. Broadly speaking, as our ability to engineer the conditional accumulation of pigments in plant tissues increases, following the processing of different inputs through complex genetic circuits, novel information transmission systems between plants and humans (or machines) are expected to arise, especially in a global scenario of search for sustainable elements. This is not otherwise different, at least in concept, from the plant-animal communication channels already observed in nature. ${ }^{47} \mathrm{We}$ envision the use of ready-to-use portable genetic systems encapsulated in agrobacteria to be used as smart biodevices that can make appropriate decisions (e.g., in diagnostics) after certain processing (computation) of the signals perceived from the plant molecular medium. ${ }^{48}$ 


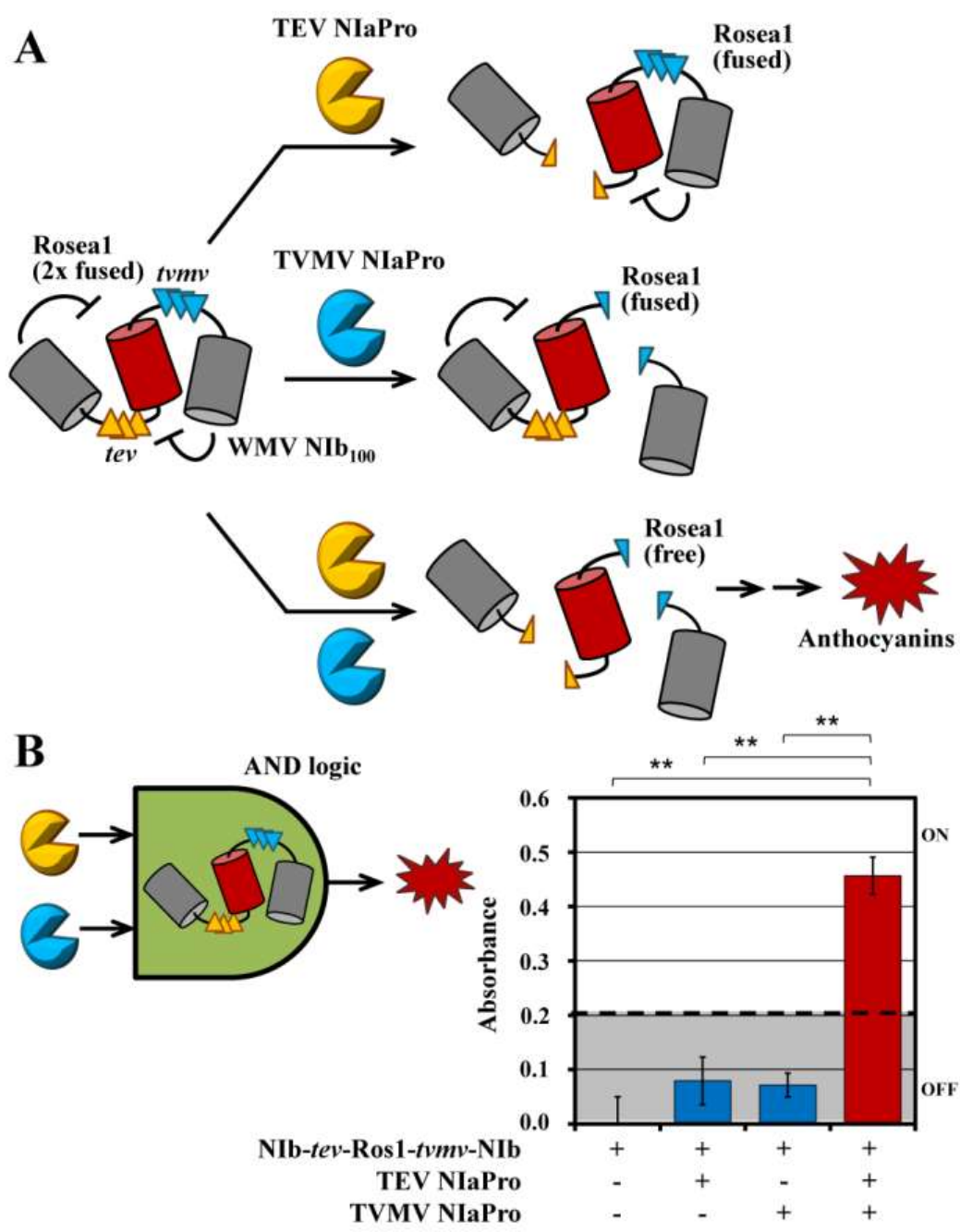

Figure 5. Synthetic circuit capable of performing Boolean AND computation in plants with visual output. (A) Schematic representation of the reactions in which the reporter construct $\mathrm{NIb}_{100}-3 \times t e v-\operatorname{Ros} 1-3 \times t v m v-\mathrm{NIb}_{100}$ responds activating the accumulation of pigmented anthocyanins in the presence of TEV and TVMV NIaPros (AND logic gate). (B) Graphic representation of the absorbance in $N$. benthamiana tissues infiltrated with $A$. tumefaciens to express the reporter constructs $\mathrm{NIb}_{100}-3 \times t e v-\operatorname{Ros} 1-3 \times t v m v-\mathrm{NIb}_{100}$ alone or with one NIaPro (blue bars) or with both TEV and TVMV NIaPros as indicated (red bars). Tissues from three independent plants were collected at 6 dpi and anthocyanins were quantified at $535 \mathrm{~nm}$. Error bars represent the standard error of the mean. ${ }^{* *} P \leq 0.01$ (one-tailed, heteroscedastic $t$-test).

\section{MATERIALS AND METHODS}

\section{Plasmid construction.}

Plasmids were constructed by Gibson assembly, ${ }^{49}$ using the NEBuilder HiFi DNA Assembly master mix (New England Biolabs). For this purpose, DNA fragments were amplified by PCR using the Phusion High-Fidelity DNA polymerase (Thermo Scientific). The sequences of the 
resulting constructs (SI Figures S2, S3 and S4) were experimentally confirmed (3130x1 Genetic Analyzer, Life Technologies). The plasmids to express TEV recombinant clones TEV-Ros1, TEV-Ros1P1, TEV-Ros1HCPro and TEV-Ros1NIb (SI Figure S2) were constructed on the basis of pGTEVa. ${ }^{33}$ The plasmids to express reporter constructs Ros1-tev-NIb (and the deleted

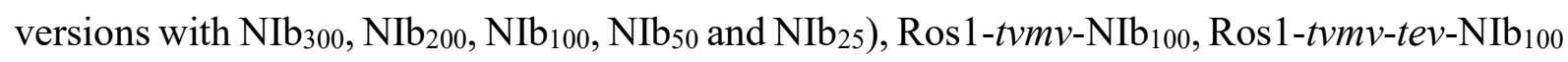
and $\mathrm{NIb}_{100}-3 \times t e v-\operatorname{Ros} 1-3 \times t v m v-\mathrm{NIb}_{100}$ (SI Figure S3), as well as the plasmids to singly express and co-express the TEV and TVMV NIaPros (SI Figure S4), were constructed on the basis of pG35CPMVZ (SI Figure S5). This plasmid is a derivative of pCLEAN-G181 (GenBank accession number EU186083) and pG35Z, ${ }^{34}$ which contains, between the left and right borders of T-DNA, an expression cassette that consist of the CaMV 35S promoter, a modified version of the CPMV RNA-2 5' UTR, ${ }^{50}$ a polylinker with two Bsa I sites, CPMV RNA-2 3' UTR, and the CaMV 35S terminator.

\section{Plant inoculation for viral infection.}

A. tumefaciens GV3101:pMP90, which contained helper plasmid pCLEAN-S48, ${ }^{51}$ were transformed with the different plasmids that contained the recombinant TEV clones with Rosea1 cDNA in various positions (Fig. S1). The transformed A. tumefaciens were grown to an optical density at $600 \mathrm{~nm}\left(\mathrm{OD}_{600}\right)$ of approximately 1.0 and recovered by centrifugation. Cells were resuspended at an $\mathrm{OD}_{600}$ of 0.5 in $10 \mathrm{mM}$ MES-NaOH, pH 5.6, $10 \mathrm{mM} \mathrm{MgCl}_{2}$ and 150 $\mu \mathrm{M}$ acetosyringone, and induced for $3 \mathrm{~h}$ at $28^{\circ} \mathrm{C}$. These cultures were used to agroinoculate the 4.5-week-old tobacco (Nicotiana tabacum L. cv. Xanthi nc) plants that were cultivated in a growth chamber at $25^{\circ} \mathrm{C}$ in a 12 -h day-night photoperiod.

\section{Analysis of viral infection by RT-PCR.}

RNA was purified from the upper non-inoculated leaves of the inoculated tobacco plants using silica gel columns (Zymo Research). Aliquots of the RNA preparations were subjected to reverse transcription with primer P1 (5'-CTCGCACTACATAGGAGAATTAGAC-3'). The products of this reaction were amplified by PCR with Thermus thermophilus DNA polymerase (Biotools) using a pair of primers (PII 5'-AGTGGCACTGTGGGTGCTGGTGTTG-3' and PIII 5'-CTGGCGGACCCCTAATAG-3'), respectively homologous and complementary to the 5' and 3' ends of TEV coat protein cistron. The PCR products were separated by electrophoresis in a $1 \%$ agarose gel in TAE buffer ( $40 \mathrm{mM}$ Tris, $20 \mathrm{mM}$ sodium acetate, $1 \mathrm{mM}$ EDTA, pH 7.2). The gel was finally stained in a solution of $1 \mathrm{mg} / \mathrm{ml}$ ethidium bromide. 


\section{Plant inoculation for transient expression of synthetic circuits.}

A. tumefaciens (the same strain as above) were also transformed with plasmids to express the reporter constructs (SI Figure S3) and TEV and TVMV NIaPros (SI Figure S4). Cultures were grown, harvested and induced as explained above with the only difference being that here induction was done at an $\mathrm{OD}_{600}$ of 1.0. In the different experiments, the A. tumefaciens cultures that expressed the reporter constructs were mixed with an equal volume of agroinoculation buffer (controls) or with the cultures that expressed the different NIaPro combinations. These mixtures were used to infiltrate the underside of leaves from the 4.5-week-old N. benthamiana plants using a needleless syringe. Plants were cultivated as explained above.

\section{Analysis of anthocyanins.}

The infiltrated tissues from the $N$. benthamiana plants were harvested at 6 dpi and homogenized in 10 volumes of extraction solution $(1 \% \mathrm{HCl}$ in methanol) with a Polytron (Kinematica). Each individual tissue sample consisted of two agroinfiltrated areas from two different leaves of the same plant. Extracts were vigorously vortexed and incubated on ice for $1 \mathrm{~h}$ with sporadic vortexing. Extracts were clarified by centrifugation for $10 \mathrm{~min}$ at $12000 \mathrm{~g}$. The aliquots of the supernatants were diluted to 1:10 in extraction solution (final tissue:extraction solution ratio of 1:100) and absorbance was measured at $535 \mathrm{~nm}$ (UV-3100PC, VWR). All the experimental values were obtained in triplicate from the agroinfiltrated tissues from three independent plants. The average $(n=5)$ absorbance of control extracts from tissues infiltrated under the same conditions with an empty $A$. tumefaciens culture (no expression plasmid) were subtracted from all absorbance values (to remove the basal contribution from the plant). Background absorbance was 0.148 and 0.149 , respectively, for samples corresponding to final $\mathrm{OD}_{600}$ of 0.5 and 1.0.

\section{ACKNOWLEDGEMENTS}

This research was supported by the Ministerio de Ciencia, Innovación y Universidades (Spain) grants AGL2013-49919-EXP, BIO2014-54269-R, BFU2015-66894-P and BIO2017-83184-R (co-financed FEDER funds) and by the Engineering and Physical Sciences Research Council and the Biotechnology and Biological Sciences Research Council (UK) grant BB/M017982/1. E.M. was the recipient of a pre-doctoral fellowship (AP2012-3751) from the Ministerio de Educación, Cultura y Deporte (Spain). 


\section{REFERENCES}

(1) Phoolcharoen, W., Bhoo, S. H., Lai, H., Ma, J., Arntzen, C. J., Chen, Q., and Mason, H. S. (2011) Expression of an immunogenic Ebola immune complex in Nicotiana benthamiana. Plant Biotechnol. J. 9, 807-816.

(2) Verpoorte, R., and Memelink, J. (2002) Engineering secondary metabolite production in plants. Curr. Opin. Biotechnol. 13, 181-187.

(3) Antunes, M. S., Morey, K. J., Smith, J. J., Albrecht, K. D., Bowen, T. A., Zdunek, J. K., Troupe, J. F., Cuneo, M. J., Webb, C. T., Hellinga, H. W., and Medford, J. I. (2011) Programmable ligand detection system in plants through a synthetic signal transduction pathway. PLoS One 6, e16292.

(4) Desai, P. N., Shrivastava, N., and Padh, H. (2010) Production of heterologous proteins in plants: strategies for optimal expression. Biotechnol. Adv. 28, 427-435.

(5) Ausländer, S., Ausländer, D., Muller, M., Wieland, M., and Fussenegger, M. (2012) Programmable single-cell mammalian biocomputers. Nature 487, 123-127.

(6) Siuti, P., Yazbek, J., and Lu, T. K. (2013) Synthetic circuits integrating logic and memory in living cells. Nat. Biotechnol. 31, 448-452.

(7) Cameron, D. E., Bashor, C. J., and Collins, J. J. (2014) A brief history of synthetic biology. Nat. Rev. Microbiol. 12, 381-390.

(8) Win, M. N., and Smolke, C. D. (2007) A modular and extensible RNA-based generegulatory platform for engineering cellular function. Proc. Natl. Acad. Sci. USA 104, 1428314288.

(9) Qi, L. S., Larson, M. H., Gilbert, L. A., Doudna, J. A., Weissman, J. S., Arkin, A. P., and Lim, W. A. (2013) Repurposing CRISPR as an RNA-guided platform for sequence-specific control of gene expression. Cell 152, 1173-1183.

(10)Chappell, J., Takahashi, M. K., and Lucks, J. B. (2015) Creating small transcription activating RNAs. Nat. Chem. Biol. 11, 214-220.

(11)Dueber, J. E., Mirsky, E. A., and Lim, W. A. (2007) Engineering synthetic signaling proteins with ultrasensitive input/output control. Nat. Biotechnol. 25, 660-662.

(12)Levskaya, A., Chevalier, A. A., Tabor, J. J., Simpson, Z. B., Lavery, L. A., Levy, M., Davidson, E. A., Scouras, A., Ellington, A. D., Marcotte, E. M., and Voigt, C. A. (2005) Synthetic biology: engineering Escherichia coli to see light. Nature 438, 441-442.

(13) Gardner, T. S., Cantor, C. R., and Collins, J. J. (2000) Construction of a genetic toggle switch in Escherichia coli. Nature 403, 339-342. 
(14)Friedland, A. E., Lu, T. K., Wang, X., Shi, D., Church, G., and Collins, J. J. (2009) Synthetic gene networks that count. Science 324, 1199-1202.

(15) Stricker, J., Cookson, S., Bennett, M. R., Mather, W. H., Tsimring, L. S., and Hasty, J. (2008) A fast, robust and tunable synthetic gene oscillator. Nature 456, 516-519.

(16) Elowitz, M. B., and Leibler, S. (2000) A synthetic oscillatory network of transcriptional regulators. Nature 403, 335-338.

(17) Salis, H. M., Mirsky, E. A., and Voigt, C. A. (2009) Automated design of synthetic ribosome binding sites to control protein expression. Nat. Biotechnol. 27, 946-950.

(18) Mutalik, V. K., Qi, L., Guimaraes, J. C., Lucks, J. B., and Arkin, A. P. (2012) Rationally designed families of orthogonal RNA regulators of translation. Nat. Chem. Biol. 8, 447-454.

(19) Kinney, J. B., Murugan, A., Callan, C. G., Jr., and Cox, E. C. (2010) Using deep sequencing to characterize the biophysical mechanism of a transcriptional regulatory sequence. Proc. Natl. Acad. Sci. USA 107, 9158-9163.

(20) Ye, X., Al-Babili, S., Klöti, A., Zhang, J., Lucca, P., Beyer, P., and Potrykus, I. (2000) Engineering the provitamin A ( $\beta$-carotene) biosynthetic pathway into (carotenoid-free) rice endosperm. Science 287, 303-305.

(21) de Lange, O., Klavins, E., and Nemhauser, J. (2017) Synthetic genetic circuits in crop plants. Curr. Opin. Biotechnol. 49, 16-22.

(22) Schaumberg, K. A., Antunes, M. S., Kassaw, T. K., Xu, W., Zalewski, C. S., Medford, J. I., and Prasad, A. (2016) Quantitative characterization of genetic parts and circuits for plant synthetic biology. Nat. Methods 13, 94-100.

(23) Revers, F., and García, J. A. (2015) Molecular biology of potyviruses. Adv. Virus Res. 92, 101-199.

(24) Verchot, J., Koonin, E. V., and Carrington, J. C. (1991) The 35-kDa protein from the $\mathrm{N}$-terminus of the potyviral polyprotein functions as a third virus-encoded proteinase. Virology $185,527-535$.

(25) Adams, M. J., Antoniw, J. F., and Beaudoin, F. (2005) Overview and analysis of the polyprotein cleavage sites in the family Potyviridae. Mol. Plant Pathol. 6, 471-487.

(26) Carrington, J. C., and Dougherty, W. G. (1987) Small nuclear inclusion protein encoded by a plant potyvirus genome is a protease. J. Virol. 61, 2540-2548.

(27) Martínez, F., Rodrigo, G., Aragonés, V., Ruiz, M., Lodewijk, I., Fernández, U., Elena, S. F., and Daròs, J. A. (2016) Interaction network of tobacco etch potyvirus NIa protein with the host proteome during infection. BMC Genomics 17, 87. 
(28) Cesaratto, F., Burrone, O. R., and Petris, G. (2016) Tobacco Etch Virus protease: A shortcut across biotechnologies. J. Biotechnol. 231, 239-249.

(29)Zhang, Y., Butelli, E., and Martin, C. (2014) Engineering anthocyanin biosynthesis in plants. Curr. Opin. Plant Biol. 19, 81-90.

(30) Butelli, E., Titta, L., Giorgio, M., Mock, H. P., Matros, A., Peterek, S., Schijlen, E. G., Hall, R. D., Bovy, A. G., Luo, J., and Martin, C. (2008) Enrichment of tomato fruit with healthpromoting anthocyanins by expression of select transcription factors. Nat. Biotechnol. 26, 13011308.

(31) Bedoya, L. C., Martínez, F., Orzáez, D., and Daròs, J. A. (2012) Visual tracking of plant virus infection and movement using a reporter MYB transcription factor that activates anthocyanin biosynthesis. Plant Physiol. 158, 1130-1138.

(32) Majer, E., Llorente, B., Rodríguez-Concepción, M., and Daròs, J. A. (2017) Rewiring carotenoid biosynthesis in plants using a viral vector. Sci. Rep. 7, 41645.

(33) Majer, E., Daròs, J. A., and Zwart, M. P. (2013) Stability and fitness impact of the visually discernible Rosea1 marker in the Tobacco etch virus genome. Viruses 5, 2153-2168.

(34) Cordero, T., Cerdán, L., Carbonell, A., Katsarou, K., Kalantidis, K., and Daròs, J. A. (2017) Dicer-Like 4 Is Involved in Restricting the Systemic Movement of Zucchini yellow mosaic virus in Nicotiana benthamiana. Mol. Plant Microbe Interact. 30, 63-71.

(35) Cordero, T., Mohamed, M. A., López-Moya, J. J., and Daròs, J. A. (2017) A recombinant Potato virus $Y$ infectious clone tagged with the Rosea1 visual marker (PVY-Ros1) facilitates the analysis of viral infectivity and allows the production of large amounts of anthocyanins in Plants. Front. Microbiol. 8, 611.

(36) Passeri, V., Koes, R., and Quattrocchio, F. M. (2016) New challenges for the design of high value plant products: stabilization of anthocyanins in plant vacuoles. Front. Plant Sci. 7, 153.

(37) Majer, E., Salvador, Z., Zwart, M. P., Willemsen, A., Elena, S. F., and Daròs, J. A. (2014) Relocation of the NIb gene in the tobacco etch potyvirus genome. J. Virol. 88, 45864590 .

(38) Li, X. H., Valdez, P., Olvera, R. E., and Carrington, J. C. (1997) Functions of the tobacco etch virus RNA polymerase (NIb): subcellular transport and protein-protein interaction with VPg/proteinase (NIa). J. Virol. 71, 1598-1607.

(39) Gibbs, A., and Ohshima, K. (2010) Potyviruses and the digital revolution, Annu. Rev. Phytopathol. 48, 205-223. 
(40) Bedoya, L., Martínez, F., Rubio, L., and Daròs, J. A. (2010) Simultaneous equimolar expression of multiple proteins in plants from a disarmed potyvirus vector. J. Biotechnol. 150, 268-275.

(41) Sainsbury, F., Thuenemann, E. C., and Lomonossoff, G. P. (2009) pEAQ: versatile expression vectors for easy and quick transient expression of heterologous proteins in plants. Plant Biotechnol. J. 7, 682-693.

(42) Tözsér, J., Tropea, J. E., Cherry, S., Bagossi, P., Copeland, T. D., Wlodawer, A., and Waugh, D. S. (2005) Comparison of the substrate specificity of two potyvirus proteases. FEBS J. 272, 514-523.

(43) Calles, B., and de Lorenzo, V. (2013) Expanding the boolean logic of the prokaryotic transcription factor XylR by functionalization of permissive sites with a protease-target sequence. ACS Synth. Biol. 2, 594-603.

(44)Fernandez-Rodriguez, J., and Voigt, C. A. (2016) Post-translational control of genetic circuits using Potyvirus proteases. Nucleic Acids Res. 44, 6493-6502.

(45) Khalil, A. S., and Collins, J. J. (2010) Synthetic biology: applications come of age. Nat. Rev. Genet. 11, 367-379.

(46) Sainsbury, F., and Lomonossoff, G. P. (2014) Transient expressions of synthetic biology in plants. Curr. Opin. Plant Biol. 19, 1-7.

(47) Schaefer, H. M., Schaefer, V., and Levey, D. J. (2004) How plant-animal interactions signal new insights in communication. Trends Ecol. Evol. 19, 577-584.

(48) Riglar, D. T., and Silver, P. A. (2018) Engineering bacteria for diagnostic and therapeutic applications. Nat. Rev. Microbiol. 16, 214-225.

(49) Gibson, D. G., Young, L., Chuang, R. Y., Venter, J. C., Hutchison, C. A., 3rd, and Smith, H. O. (2009) Enzymatic assembly of DNA molecules up to several hundred kilobases. Nat. Methods 6, 343-345.

(50) Sainsbury, F., and Lomonossoff, G. P. (2008) Extremely high-level and rapid transient protein production in plants without the use of viral replication. Plant. Physiol. 148, 1212-1218.

(51) Thole, V., Worland, B., Snape, J. W., and Vain, P. (2007) The pCLEAN dual binary vector system for Agrobacterium-mediated plant transformation. Plant Physiol. 145, 12111219. 


\section{SUPPORTING INFORMATION}

Figure S1. Schematic representation of TEV genome indicating the positions where the Rosea1 coding sequence was fused in TEV-Ros1P1, TEV-Ros1HCPro and TEV-Ros1NIb. Rosea1 is expressed as a free protein in TEV-Ros1 because it is flanked by two NIaPro cleavage sites (black triangles). Lines represent TEV 5' and 3' UTR and boxes represent P1, HC-Pro, P3, P3N-PIPO, 6K1, CI, 6K2, VPg, NIaPro, NIb and CP cistrons, as indicated. Some sequences were inserted next to Rosea1 in some of the constructs, as indicated, to assure proteolytic

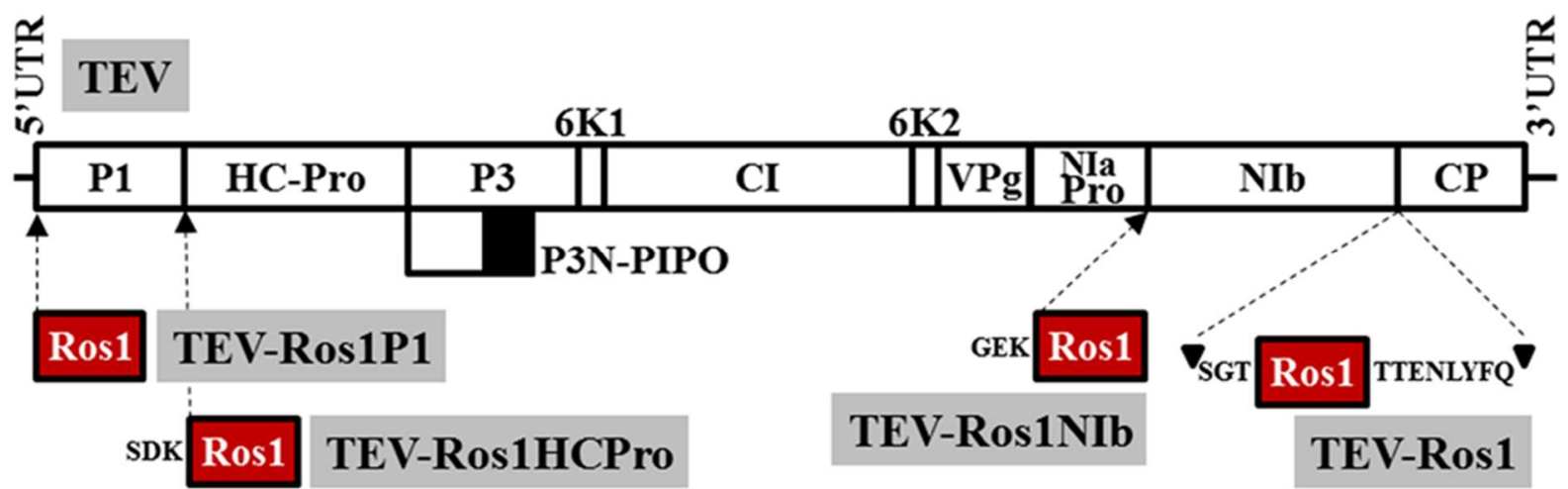

cleavage.

Figure S2. Sequences of recombinant TEV clones. Sequences of wild-type TEV, the recombinant clones TEV-Ros1P1, TEV-Ros1HcPro and TEV-Ros1NIb in which the Rosea1 coding sequence is fused to the 5' end of P1, HC-Pro and NIb cistrons, respectively, and the recombinant clone TEV-Ros1 in which the Rosea1 coding sequence is inserted between NIb and $\mathrm{CP}$ cistrons and flanked by sequences that complement the split $\mathrm{NIb} / \mathrm{CP}$ cleavage site to promote the proteolytic release of Rosea1. Wild-type TEV sequence corresponds to Genbank accession number DQ986288 including two silent mutations (G273A and A1119G, underlined). A. majus Rosea1 cDNA (DQ275529) is in red. Limits between TEV cistrons are marked on blue background. Sequences inserted to complement proteolytic cleavage sites are in blue.

>TEV (wild-type)

AAAATAACAAATCTCAACACAACATATACAAAACAAACGAATCTCAAGCAATCAAGCATTCTACTTCTATTGCAG CAАTTTAAATCATTTCTTTTAAAGCAAAAGCAATTTTCTGAAAATTTTCACCATTTACGAACGATAGCCATGGCA CTCATCTTTGGCACAGTCAACGCTAACATCCTGAAGGAAGTGTTCGGTGGAGCTCGTATGGCTTGCGTTACCAGC GCACATATGGCTGGAGCGAATGGAAGCATTTTGAAGAAGGCAGAAGAAACCTCTCGTGCAATCATGCACAAACCA GTGATCTTCGGAGAAGACTACATTACCGAGGCAGACTTGCCTTACACACCACTCCATTTAGAGGTCGATGCTGAA ATGGAGCGGATGTATTATCTTGGTCGTCGCGCGCTCACCCATGGCAAGAGACGCAAAGTTTCTGTGAATAACAAG AGGAACAGGAGAAGGAAAGTGGCCAAAACGTACGTGGGGCGTGATTCCATTGTTGAGAAGATTGTAGTGCCCCAC 
ACCGAGAGAAAGGTTGATACCACAGCAGCAGTGGAAGACATTTGCAATGAAGCTACCACTCAACTTGTGCATAAT AGTATGCCAAAGCGTAAGAAGCAGAAAAACTTCTTGCCCGCCACTTCACTAAGTAACGTGTATGCCCAAACTTGG AGCATAGTGCGCAAACGCCATATGCAGGTGGAGATCATTAGCAAGAAGAGCGTCCGAGCGAGGGTCAAGAGATTT GAGGGCTCGGTGCAATTGTTCGCAAGTGTGCGTCACATGTATGGCGAGAGGAAAAGGGTGGACTTACGTATTGAC AACTGGCAGCAAGAGACACTTCTAGACCTTGCTAAAAGATTTAAGAATGAGAGAGTGGATCAATCGAAGCTCACT TTTGGTTCAAGTGGCCTAGTTTTGAGGCAAGGCTCGTACGGACCTGCGCATTGGTATCGACATGGTATGTTCATT GTACGCGGTCGGTCGGATGGGATGTTGGTGGATGCTCGTGCGAAGGTAACGTTCGCTGTTTGTCACTCAATGACA CATTATAGCGACAAATCAATCTCTGAGGCATTCTTCATACCATACTCTAA GAAATTCTTGGAGTTGAGGCCAGAT GGAATCTCCCATGAGTGTACAAGAGGAGTATCAGTTGAGCGGTGCGGTGAGGTGGCTGCAATCCTGACĀCAAGCA CTTTCACCGTGTGGTAAGATCACATGCAAACGTTGCATGGTTGAAACACCTGACATTGTTGAGGGTGAGTCGGGA GACAGTGTCACCAACCAAGGTAAGCTCCTAGCAATGCTGAAAGAACAGTATCCAGATTTCCCAATGGCCGAGAAA CTACTCACAAGGTTTTTGCAACAGAAATCACTAGTAAATACAAATTTGACAGCCTGCGTGAGCGTCAAACAACTC ATTGGTGACCGCAAACAAGCTCCATTCACACACGTACTGGCTGTCAGCGAAATTCTGTTTAAAGGCAATAAACTA ACAGGGGCCGATCTCGAAGA GGCAAGCACACATATGCTTGAAATAGCAAGGTTCTTGAACAATCGCACTGAAAAT ATGCGCATTGGCCACCTTGGTTCTTTCAGAAATAAAATCTCATCGAAGGCCCATGTGAATAACGCACTCATGTGT GATAATCAACTTGATCAGAATGGGAATTTTATTTGGGGACTAAGGGGTGCACACGCAAAGAGGTTTCTTAAAGGA TTTTTCACTGAGATTGACCCAAATGAAGGATACGATAAGTATGTTATCAGGAAACATATCAGGGGTAGCAGAAAG CTAGCAATTGGCAATTTGATAATGTCAACTGACTTCCAGACGCTCAGGCAACAAATTCAAGGCGAAACTATTGAG CGTAAAGAAATTGGGAATCACTGCATTTCAATGCGGAATGGTAATTACGTGTACCCATGTTGTTGTGTTACTCTT GAAGATGGTAAGGCTCAATATTCGGATCTAAAGCATCCAACGAAGAGACATCTGGTCATTGGCAACTCTGGCGAT TCAAAGTACCTAGACCTTCCAGTTCTCAATGAAGAGAAAATGTATATAGCTAATGAAGGTTATTGCTACATGAAC ATTTTCTTTGCTCTACTAGTGAATGTAAgGAAGAGGATGCAAAGGACTTCACCAAGTTTATAAGGGACACAATT GTTCCAAAGCTTGGAGCGTGGCCAACAATGCAAGATGTTGCAACTGCATGCTACTTACTTTCCATTCTTTACCCA GATGTCCTGAGTGCTGAATTACCCAGAATTTTGGTTGATCATGACAACAAAACAATGCATGTTTTGGATTCGTAT GGGTCTAGAACGACAGGATACCACATGTTGAAAATGAACACAACATCCCAGCTAATTGAATTCGTTCATTCAGGT TTGGAATCCGAAATGAAAACTTACAATGTTGGAGGGATGAACCGAGATATGGTCACACAAGGTGCAATTGAGATG TTGATCAAGTCCATATACAAACCACATCTCATGAAGCAGTTACTTGAGGAGGAGCCATACATAATTGTCCTGGCA ATAGTCTCCCCTTCAATTTAATTGCCATGTACAACTCTGGAACTTTTGAGCAGGCGTTACAAATGTGGTTGCCA AATACAATGAGGTTAGCTAACCTCGCTGCCATCTTGTCAGCCTTGGCGCAAAAGTTAACTTTGGCAGACTTGTTC GTCCAGCAGCGTAATTTGATTAATGAGTATGCGCAGGTAATTTTGGACAATCTGATTGACGGTGTCAGGGTTAAC CATTCGCTATCCCTAGCAATGGAAATTGTTACTATTAAGCTGGCCACCCAAGAGATGGACATGGCGTTGAGGGAA GGTGGCTATGCTGTGACCTCTGAAAAGGTGCATGAAATGTTGGAAAAAAACTATGTAAAGGCTTTGAAGGATGCA TGGGACGAATTAACTTGGTTGGAAAAATTCTCCGCAATCAGGCATTCAAGAAAGCTCTTGAAATTTGGGCGAAAG CCTTTAATCATGAAAAACACCGTAGATTGCGGCGGACATATAGACTTGTCTGTGAAATCGCTTTTCAAGTTCCAC TTGGAACTCCTGAAGGGAACCATCTCAAGAGCCGTAAATGGTGGTGCAAGAAAGGTAAGAGTAGCGAAGAATGCC ATGACAAAAGGGGTTTTTCTCAAAATCTACAGCATGCTTCCTGACGTCTACAAGTTTATCACAGTCTCGAGTGTC CTTTCCTTGTTGTTGACATTCTTATTTCAAATTGACTGCATGATAAGGGCACACCGAGAGGCGAAGGTTGCTGCA CAGTTGCAGAAAGAGAGCGA GTGGGACAATATCATCAATAGAACTTTCCAGTATTCTAAGCTTGAAAATCCTATT GGCTATCGCTCTACAGCGGAGGAAAGACTCCAATCAGAACACCCCGAGGCTTTCGAGTACTACAAGTTTTGCATT GGAAAGGAAGACCTCGTTGAACAGGCAAAACAACCGGAGATAGCATACTTTGAAAAGATTATAGCTTTCATCACA CTTGTATTAATGGCTTTTGACGCTGAGCGGAGTGATGGAGTGTTCAAGATACTCAATAAGTTCAAAGGAATACTG AGCTCAACGGAGAGGGAGATCATCTACACGCAGAGTTTGGATGATTACGTTACAACCTTTGATGACAATATGACA ATCAACCTCGAGTTGAATATGGATGAACTCCACAAGACGAGCCTTCCTGGAGTCACTTTTAAGCAATGGTGGAAC AACCAAATCAGCCGAGGCAACGTGAAGCCACATTATAGAACTGAGGGGCACTTCATGGAGTTTACCAGAGATACT GCGGCATCGGTTGCCAGCGAGATATCACACTCACCCGCAAGAGATTTTCTTGTGAGAGGTGCTGTTGGATCTGGA AAATCCACAGGACTTCCATACCATTTATCAAAGAGAGGGAGAGTGTTAATGCTTGAGCCTACCAGACCACTCACA GATAACGTGCACAAGCAACTGAGAAGTGAACCATTTAACTGCTTCCCAACTTTGAGGATGAGAGGGAAGTCAACT TTTGGGTCATCACCGATTACAGTCATGACTAGTGGATTCGCTTTACACCATTTTGCACGAAACATAGCTGAGGTA AAAACATACGATTTTGCATAATTGATGAATGTCATGTGAATGATGCTTCTGCTATAGCGTTTAGGAATCTACTG TTTGAACATGAATTTGAAGGAAAAGTCCTCAAAGTGTCAGCCACACCACCAGGTAGAGAAGTTGAATTCACAACT CAGTTTCCCGTGAAACTCAAGATAGAAGAGGCTCTTAGCTTTCAGGAATTTGTAAGTTTACAAGGGACAGGTGCC AACGCCGATGTGATTAGTTGTGGCGACAACATACTAGTATATGTTGCTAGCTACAATGATGTTGATAGTCTTGGC AAGCTCCTTGTGCAAAAGGGATACAAAGTGTCGAAGATTGATGGAAGAACAATGAAGAGTGGAGGAACTGAAATA ATCACTGAAGGTACTTCAGTGAAAAAGCATTTCATAGTCGCAACTAATATTATTGAGAATGGTGTAACCATTGAC ATTGATGTAGTTGTGGATTTTGGGACTAAGGTTGTACCAGTTTTGGATGTGGACAATAGAGCGGTGCAGTACAAC AAAACTGTGGTGAGTTATGGGGAGCGCATCCAAAGACTCGGTAGAGTTGGGCGACACAAGGAAGGAGTAGCACTT CGAATTGGCCAAACAAATAAAACACTGGTTGAAATTCCAGAAATGGTTGCCACTGAAGCTGCCTTTCTATGCTTC ATGTACAATTTGCCAGTGACAACACAGAGTGTTTCAACCACACTGCTGGAAAATGCCACATTATTACAAGCTAGA ACTATGGCACAGTTTGAGCTATCATATTTTTACACAATTAATTTTGTGCGATTTGATGGTAGTATGCATCCAGTC ATACATGACAAGCTGAAGCGCTTTAAGCTACACACTTGTGAGACATTCCTCAATAAGTTGGCGATCCCAAATAAA GGCTTATCCTCTTGGCTTACGAGTGGAGAGTATAAGCGACTTGGTTACATAGCAGAGGATGCTGGCATAAGAATC 
CCATTCGTGTGCAAAGAAATTCCAGACTCCTTGCATGAGGAAATTTGGCACATTGTAGTCGCCCATAAAGGTGAC TCGGGTATTGGGAGGCTCACTAGCGTACAGGCAGCAAAGGTTGTTTATACTCTGCAAACGGATGTGCACTCAATT GCGAGGACTCTAGCATGCATCAATAGACTCATAGCACATGAACAAATGAAGCAGAGTCATTTTGAAGCCGCAACT GGGAGAGCATTTTCCTTCACAAATTACTCAATACAAAGCATATTTGACACGCTGAAAGCAAATTATGCTACAAAG CATACGAAAGAAAATATTGCAGTGCTTCAGCAGGCAAAAGATCAATTGCTAGAGTTTTCGAACCTAGCAAAGGAT CAAGATGTCACGGGTATCATCCAAGACTTCAATCACCTGGAAACTATCTATCTCCAATCAGATAGCGAAGTGGCT AAGCATCTGAAGCTTAAAAGTCACTGGAATAAAAGCCAAATCACTAGGGACATCATAATAGCTTTGTCTGTGTTA ATTGGTGGTGGATGGATGCTTGCAACGTACTTCAAGGACAAGTTCAATGAACCAGTCTATTTCCAAGgGAAGAAG AATCAGAAGCACAAGCTTAAGATGAGAGAGGCGCGTGGGGCTAGAGGGCAATATGAGGTTGCAGCGGAGCCAGAG GCGCTAGAACATTACTTTGGAAGCGCATATAATAACAAAGGAAAGCGCAAGGGCACCACGAGAGGAATGGGTGCA AAGTCTCGGAAATTCATAAACATGTATGGGTTTGATCCAACTGATTTTTCATACATTAGGTTTGTGGATCCATTG ACAGGTCACACTATTGATGA GTCCACAAACGCACCTATTGATTTAGTGCAGCATGAGTTTGGAAAGGTTAGAACA CGCATGTTAATTGACGATGAGATAGAGCCTCAAAGTCTTAGCACCCACACCACAATCCATGCTTATTTGGTGAAT AGTGGCACGAAGAAAGTTCTTAAGGTTGATTTAACACCACACTCGTCGCTACGTGCGAGTGAGAAATCAACAGCA ATAATGGGATTTCCTGAAAGGGAGAATGAATTGCGTCAAACCGGCATGGCAGTGCCAGTGGCTTATGATCAATTG CCACCAAAGAGTGAGGACTTGACGTTTGAAGGAGAAAGCTTGTTTAAGGGACCACGTGATTACAACCCGATATCG AGCACCATTTGTCACTTGACGAATGAATCTGATGGGCACACAACATCGTTGTATGGTATTGGATTTGGTCCCTTC ATCATTACAAACAAGCACTTGTTTAGAAGAAATAATGGAACACTGTTGGTCCAATCACTACATGGTGTATTCAAG GTCAAGAACACCACGACTTTGCAACAACACCTCATTGATGGGAGGGACATGATAATTATTCGCATGCCTAAGGAT TTCCCACCATTTCCTCAAAAGCTGAAATTTAGAGAGCCACAAAGGGAAGAGCGCATATGTCTTGTGACAACCAAC TTCCAAACTAAGAGCATGTCTAGCATGGTGTCAGACACTAGTTGCACATTCCCTTCATCTGATGGCATATTCTGG AAGCATTGGATTCAAACCAAGGATGGGCAGTGTGGCAGTCCATTAGTATCAACTAGAGATGGGTTCATTGTTGGT ATACACTCAGCATCGAATTTCACCAACACAAACAATTATTTCACAAGCGTGCCGAAAAACTTCATGGAATTGTTG ACAAATCAGGAGGCGCAGCA GTGGGTTAGTGGTTGGCGATTAAATGCTGACTCAGTATTGTGGGGGGGCCATAAA GTTTTCATGAGCAAACCTGAAGAGCCTTTTCAGCCAGTTAAGGAAGCGACTCAACTCATGAGTGAATTGGTGTAC TCGCAAGGGGAGAAGAGGAAATGGGTCGTGGAAGCACTGTCAGGGAACTTGAGGCCAGTGGCTGAGTGTCCCAGT CAGTTAGTCACAAAGCATGT GGTTAAAGGAAAGTGTCCCCTCTTTGAGCTCTACTTGCAGTTGAATCCAGAAAAG GAAGCATATTTTAAACCGATGATGGGAGCATATAAGCCAAGTCGACTTAATAGAGAGGCGTTCCTCAAGGACATT CTAAAATATGCTAGTGAAATTGAGATTGGGAATGTGGATTGTGACTTGCTGGAGCTTGCAATAAGCATGCTCATC ACAAAGCTCAAGGCGTTAGGATTCCCAACTGTGAACTACATCACTGACCCAGAGGAAATTTTTAGTGCATTGAAT ATGAAAGCAGCTATGGGAGCACTATACAAAGGCAAGAAGAAAGAAGCTCTCAGCGAGCTCACACTAGATGAGCAG GAGGCAATGCTCAAAGCAAGTTGCCTGCGACTGTATACGGGAAAGCTGGGAATTTGGAATGGCTCATTGAAAGCA GAGTTGCGTCCAATTGAGAAGGTTGAAAACAACAAAACGCGAACTTTCACAGCAGCACCAATAGACACTCTTCTT GCTGGTAAAGTTTGCGTGGATGATTTCAACAATCAATTTTATGATCTCAACATAAAGGCACCATGGACAGTTGGT ATGACTAAGTTTTATCAGGGGTGGAATGAATTGATGGAGGCTTTACCAAGTGGGTGGGTGTATTGTGACGCTGAT GGTTCGCAATTCGACAGTTCCTTGACTCCATTCCTCATTAATGCTGTATTGAAAGTGCGACTTGCCTTCATGGAG GAATGGGATATTGGTGAGCAAATGCTGCGAAATTTGTACACTGAGATAGTGTATACACCAATCCTCACACCGGAT GGTACTATCATTAAGAAGCATAAAGGCAACAATAGCGGGCAACCTTCAACAGTGGTGGACAACACACTCATGGTC ATTATTGCAATGTTATACACATGTGAGAAGTGTGGAATCAACAAGGAAGA GATTGTGTATTACGTCAATGGCGAT GACCTATTGATTGCCATTCACCCAGATAAAGCTGAGAGGTTGAGTGGATTCAAAGAATCTTTCGGAGAGTTGGGC CTGAAATATGAATTTGACTGCACCACCAGGGACAAGACACAGTTGTGGTTCATGTCACACAGGGCTTTGGAGAGG GATGGCATGTATATACCAAAGCTAGAAGAAGAAAGGATTGTTTCTATTTTGGAATGGGACAGATCCAAAGAGCCG TCACATAGGCTTGAAGCCATCTGTGCATCAATGATCGAAGCATGGGGTTATGACAAGCTGGTTGAAGAAATCCGC AATTTCTATGCATGGGTTTTGGAACAAGCGCCGTATTCACAGCTTGCAGAAGAAGGAAAGGCGCCATATCTGGCT GAGACTGCGCTTAAGTTTTTGTACACATCTCAGCACGGAACAAACTCTGAGATAGAAGAGTATTTAAAAGTGTTG TATGATTACGATATTCCAACGACTGAGAATCTTTATTTTCAGAGTGGCACTGTGGGTGCTGGTGTTGACGCTGGT AAGAAGAAAGATCAAAAGGATGATAAAGTCGCTGAGCAGGCTTCAAAGGATAGGGATGTTAATGCTGGAACTTCA GGAACATTCTCAGTTCCACGAATAAATGCTATGGCCACAAAACTTCAATATCCAAGGATGAGGGGAGAGGTGGTT GTAAACTTGAATCACCTTTTAGGATACAAGCCACAGCAAATTGATTTGTCAAATGCTCGAGCCACACATGAGCAG TTTGCCGCGTGGCATCAGGCAGTGATGACAGCCTATGGAGTGAATGAAGA GCAAATGAAAATATTGCTAAATGGA TTTATGGTGTGGTGCATAGAAAATGGGACTTCCCCAAATTTGAACGGAACTTGGGTTATGATGGATGGTGAGGAG CAAGTTTCATACCCGCTGAAACCAATGGTTGAAAACGCGCAGCCAACACTGAGGCAAATTATGACACACTTCAGT GACCTGGCTGAAGCGTATATTGAGATGAGGAATAGGGAGCGACCATACATGCCTAGGTATGGTCTACAGAGAAAC ATTACAGACATGAGTTTGTCACGCTATGCGTTCGACTTCTATGAGCTAACTTCAAAAACACCTGTTAGAGCGAGG GAGGCGCATATGCAAATGAAAGCTGCTGCAGTACGAAACAGTGGAACTAGGTTATTTGGTCTTGATGGCAACGTG GGTACTGCAGAGGAAGACACTGAACGGCACACAGCGCACGATGTGAACCGTAACATGCACACACTATTAGGGGTC CGCCAGTGATAGTTTCTGCGTGTCTTTGCTTTCCGCTTTTAAGCTTATTGTAATATATATGAATAGCTATTCACA GTGGGACTTGGTCTTGTGTTGATGGTATCTTATATGTTTTAATATGTCTTATTAGTCTCATTACTTAGGCGAAC GACAAAgTGAGGTCACCTCGGTCTAATTCTCCTATGTAgTGCGAGAAAAAAAAAAAAAAAAAAAAAAAAAAAAAA AAAAAAAAAAAAAAA 
>TEV-Ros1P1 (sequence inserted between C144 and A145 of wild-type TEV)

ATGGAAAAGAATGTCGTGGAGTGAGAAAAGGTACTTGGACCAAAGAAGAAGACACTCTCTTGAGGCAATGTATA GAAGAGTATGGTGAAGGGAAATGGCATCAAGTTCCACACAGAGCAGGGTTGAACCGGTGTAGGAAGAGTTGCAGG CTGAGGTGGTTGAATTATCTGAGGCCAAATATCAAAAGAGGTCGGTTTTCGAGAGATGAAGTGGACCTAATTGTG AGGCTTCATAAGCTGTTGGGTAACAAATGGTCGCTGATTGCTGGTAGAATTCCTGGAAGGACAGCTAATGACGTG AAGAACTTTTGGAATACTCATGTGGGGAAGAATTTAGGCGAGGATGGAGAACGATGCCGGAAAAATGTTATGAAC ACAAAAACCATTAAGCTGACTAATATCGTAAGACCCCGAGCTCGGACCTTCACCGGATTGCACGTTACTTGGCCG AGAGAAGTCGGAAAAACCGATGAATTTCAAATGTCCGGTTAACAACTGATGAGATTCCAGATTGTGAGAAGCAA ACGCAATTTTACAATGATGTTGCGTCGCCACAAGATGAAGTTGAAGACTGCATTCAGTGGTGGAGTAAGTTGCTA GAAACAACGGAGGATGGGGAATTAGGAAACCTATTCGAGGAGGCCCAACAAATTGGAAAT

\begin{abstract}
>TEV-Ros1HCPro (sequence inserted between T1056 and A1057 of wild-type TEV) AGCGATAAAATGGAAAAGAATTGTCGTGGAGTGAGAAAAGGTACTTGGACCAAAGAAGAAGACACTCTCTTGAGG CAATGTATAGAAGAGTATGGTGAAGGGAAATGGCATCAAGTTCCACACAGAGCAGGGTTGAACCGGTGTAGGAAG AGTTGCAGGCTGAGGTGGTTGAATTATCTGAGGCCAAATATCAAAAGAGGTCGGTTTTCGAGAGATGAAGTGGAC CTAATTGTGAGGCTTCATAAGCTGTTGGGTAACAAATGGTCGCTGATTGCTGGTAGAATTCCTGGAAGGACAGCT AATGACGTGAAGAACTTTTGGAATACTCATGTGGGGAAGAATTTAGGCGAGGATGGAGAACGATGCCGGAAAAAT GTTATGAACACAAAAACCATTAAGCTGACTAATATCGTAAGACCCCGAGCTCGGACCTTCACCGGATTGCACGTT ACTTGGCCGAGAGAAGTCGGAAAAACCGATGAATTTTCAAATGTCCGGTTAACAACTGATGAGATTCCAGATTGT GAGAAGCAAACGCAATTTTACAATGATGTTGCGTCGCCACAAGATGAAGTTGAAGACTGCATTCAGTGGTGGAGT AAgTTGCTAGAAACAACGGA GGATGGGGAATTAGGAAACCTATTCGAGGAGGCCCAACAAATTGGAAAT
\end{abstract}

>TEV-Ros1NIb (sequence inserted between A6981 and G6982 of wild-type TEV) GGGGAAAAGATGGAAAAGAATTGTCGTGGAGTGAGAAAAGGTACTTGGACCAAAGAAGAAGACACTCTCTTGAGG CAATGTATAGAAGAGTATGGTGAAGGGAAATGGCATCAAGTTCCACACAGAGCAGGGTTGAACCGGTGTAGGAAG AGTTGCAGGCTGAGGTGGTTGAATTATCTGAGGCCAAATATCAAAAGAGGTCGGTTTTCGAGAGATGAAGTGGAC CTAATTGTGAGGCTTCATAAGCTGTTGGGTAACAAATGGTCGCTGATTGCTGGTAGAATTCCTGGAAGGACAGCT AATGACGTGAAGAACTTTTGGAATACTCATGTGGGGAAGAATTTAGGCGAGGATGGAGAACGATGCCGGAAAAAT GTTATGAACACAAAAACCATTAAGCTGACTAATATCGTAAGACCCCGAGCTCGGACCTTCACCGGATTGCACGTT ACTTGGCCGAGAGAAGTCGGAAAAACCGATGAATTTTCAAATGTCCGGTTAACAACTGATGAGATTCCAGATTGT GAGAAGCAAACGCAATTTTACAATGATGTTGCGTCGCCACAAGATGAAGTTGAAGACTGCATTCAGTGGTGGAGT AAgTTGCTAGAAACAACGGA GGATGGGGAATTAGGAAACCTATTCGAGGAGGCCCAACAAATTGGAAAT

\begin{abstract}
>TEV-Ros1 (sequence inserted between G8517 and A8518 of wild-type TEV)
TCAGGTACAATGGAAAAGAATTGTCGTGGAGTGAGAAAAGGTACTTGGACCAAAGAAGAAGACACTCTCTTGAGG CAATGTATAGAAGAGTATGGTGAAGGGAAATGGCATCAAGTTCCACACAGAGCAGGGTTGAACCGGTGTAGGAAG AGTTGCAGGCTGAGGTGGTTGAATTATCTGAGGCCAAATATCAAAAGAGGTCGGTTTTCGAGAGATGAAGTGGAC CTAATTGTGAGGCTTCATAAGCTGTTGGGTAACAAATGGTCGCTGATTGCTGGTAGAATTCCTGGAAGGACAGCT AATGACGTGAAGAACTTTTGGAATACTCATGTGGGGAAGAATTTAGGCGAGGATGGAGAACGATGCCGGAAAAAT GTTATGAACACAAAAACCATTAAGCTGACTAATATCGTAAGACCCCGAGCTCGGACCTTCACCGGATTGCACGTT ACTTGGCCGAGAGAAGTCGGAAAAACCGATGAATTTTCAAATGTCCGGTTAACAACTGATGAGATTCCAGATTGT GAGAAGCAAACGCAATTTTACAATGATGTTGCGTCGCCACAAGATGAAGTTGAAGACTGCATTCAGTGGTGGAGT AAgTTGCTAGAAACAACGGA GGATGGgGAATTAgGAAACCTATTCGAGGA GGCCCAACAAATTGGAAATACTACA GAGAACCTCTACTTTCAA
\end{abstract}

Figure S3. Sequences of the synthetic reporter constructs that allow Boolean computation in plant tissues with visual output. Roseal coding sequence is in red. The $-8 /+3$ TEV and TVMV NIaPro cleavage sites are in yellow and green, respectively, on gray background. The dinucleotides that correspond to both NIaPro cleavage positions are on highlighted on black background. Full length WMV NIb and deleted forms $\mathrm{NIb}_{300}, \mathrm{NIb}_{200}, \mathrm{NIb}_{100}, \mathrm{NIb}_{50}$ and $\mathrm{NIb}_{50}$ are in black. All sequences start with an ATG initiator codon and end with a TAA stop codon. These reporter constructs were expressed in plants under the control of CaMV 35S promoter and terminator and CPMV RNA-2 5' and 3' UTR (see SI Figure S5). Note that the -8/+3 TEV NIaPro cleavage site corresponds at the amino acid level to the NIb/CP boundary although it 
contains silent mutations to avoid extended homology with the viral sequence. In contrast the 8/+3 TVMV NIaPro cleavage site corresponds to the native NIb/CP boundary (NC_001768.1).

\begin{abstract}
$>$ Ros $1-t e v-N I b$
ATGGAAAAGAATTGTCGTGGAGTGAGAAAAGGTACTTGGACCAAAGAAGAAGACACTCTCTTGAGGCAATGTATA GAAGAGTATGGTGAAGGGAAATGGCATCAAGTTCCACACAGAGCAGGGTTGAACCGGTGTAGGAAGAGTTGCAGG CTGAGGTGGTTGAATTATCTGAGGCCAAATATCAAAAGAGGTCGGTTTTCGAGAGATGAAGTGGACCTAATTGTG AGGCTTCATAAGCTGTTGGGTAACAAATGGTCGCTGATTGCTGGTAGAATTCCTGGAAGGACAGCTAATGACGTG AAGAACTTTTGGAATACTCATGTGGGGAAGAATTTAGGCGAGGATGGAGAACGATGCCGGAAAAATGTTATGAAC ACAAAAACCATTAAGCTGACTAATATCGTAAGACCCCGAGCTCGGACCTTCACCGGATTGCACGTTACTTGGCCG AGAGAAGTCGGAAAAACCGATGAATTTTCAAATGTCCGGTTAACAACTGATGAGATTCCAGATTGTGAGAAGCAA ACGCAATTTTACAATGATGTTGCGTCGCCACAAGATGAAGTTGAAGACTGCATTCAGTGGTGGAGTAAGTTGCTA GAAACAACGGAGGATGGGGAATTAGGAAACCTATTCGAGGAGGCCCAACAAATTGGAAATACIACAGAGAACCIC IACITHCA AT CAGGIACAAGTAGAAAGGAGAGATGGGTTTTGGATGCCATGGAAGGGAATTTGGTTGCTTGTGGG CAAGCTGACAGCGCGCTAGTGACAAAGCATGTGGTTAAAGGAAAATGCCCTTATTTTTCACAATATCTCTCATTG CACAATGAAGCAAAACAGTTCTTTGAGCCATTGATGGGGGCATACCAGCCAAGCCGGTTAAATAAAGACGCTTTC AAGAAAGATTTCTTTAAATACAACAAACCGGTAGTTTTGAATGAAGTTGATTTTAACGCTTTCGAGAAAGCAGTT GAGGGAGTGATAACAATGATGGTTGACTTTGAATTCGCAGAATGCTTGTTTGTAACTGATCCTGATGAAATTTAT GGATCCCTGAACATGAAAGCCGCTGTTGGTGCTCAATACAAAGGAAAGAAACAGGATTACTTTTCTGGCATGGAT AGTTTTGATAAGGAGCGCCTGTTGTACCTTAGCTGTGAGAGGCTGTTCAATGGAGAGAAGGGAATTTGGAATGGT TCTCTAAAGGCGGAGTTGAGACCAATTGAGAAAGTGCAGGCAAACAAAACTAGAACATTTACAGCAGCACCGATT GACACATTACTTGGAGCCAAAGTTTGCGTTGATGACTTCAATAATCAATTCTACAGCTTCAACTTAAAATGTCCA TGGACAGTTGGCATGACTAAGTTTTATGGGGGTTGGGATAAGCTAATGAGGAGTTTACCTGATGGTTGGACATAT TGCCATGCAGATGGTTCACAGTTCGACAGTTCTTTAACTCCCTTGTTGTTGAATGCTGTCCTCAGTATTAGATGT TGCTTCATGGAAGATTGGTGGGTTGGAAAGGAAATGCTTGAAAACCTTTACGCTGAAATAGTTTACACACCAATC TTAGCGCCTGATGGCACAATTTTCAAAAAGTTCAGAGGGAACAACAGTGGACAGCCATCTACAGTCGTTGACAAT ACGCTTATGGTTGTCATTGCTATGTATTATTCGTGCTGTAAACAAGGTTGGTCAGAGGAGGACATTGAAAGGAGG CTGGTGTTCTTTGCCAATGGTGATGATATTATCCTGGCAGTTAGGGATGAGGATGTGTGGCTGTATGACACTCTG AGTGCTTCATTTGCTGAGCTTGGCCTGAATTACAATTTTGATGAGCGAACAAAGAAAAGAGAGGAACTGTGGTTC ATGTCACACCAAGCCATGCTAGTTGATGGGATATACATCCCAAAGCTTGAACCTGAAAGGATAGTTTCCATCTTA GAATGGGATAGGAGCAAGGAAATTATGCACCGCACTGAGGCAATTTGTGCAGCCATGATTGAAGCGTGGGGATAC ACTGAGCTTTTACAAGAAATTCGCAAATTTTATTTGTGGCTTCTGAGCAAAGATGAATTTAAGGAACTCGCAGCG TCTGGAAAAGCCCCATACATAGCTGAGACAGCGTTAAAGAAGCTCTACACAGATGTCAACACACAACCAAGTGAA TTGCAAAGATACCTTGAAGTTCTGGATTTCAGCCATACTGATGGTTGCTGCGAATCAGTGTCCCTGCAATAA
\end{abstract}

\footnotetext{
>Ros $1-$ tev $-\mathrm{NIb}_{300}$

ATGGAAAAGAATTTCGTGGAGTGAGAAAAGGTACTTGGACCAAAGAAGAAGACACTCTCTTGAGGCAATGTATA GAAGAGTATGGTGAAGGGAAATGGCATCAAGTTCCACACAGAGCAGGGTTGAACCGGTGTAGGAAGAGTTGCAGG CTGAGGTGGTTGAATTATCTGAGGCCAAATATCAAAAGAGGTCGGTTTTCGAGAGATGAAGTGGACCTAATTGTG AGGCTTCATAAGCTGTTGGGTAACAAATGGTCGCTGATTGCTGGTAGAATTCCTGGAAGGACAGCTAATGACGTG AAGAACTTTTGGAATACTCATGTGGGGAAGAATTTAGGCGAGGATGGAGAACGATGCCGGAAAAATGTTATGAAC ACAAAAACCATTAAGCTGACTAATATCGTAAGACCCCGAGCTCGGACCTTCACCGGATTGCACGTTACTTGGCCG AGAGAAGTCGGAAAAACCGATGAATTTTCAAATGTCCGGTTAACAACTGATGAGATTCCAGATTGTGAGAAGCAA ACGCAATTTTACAATGATGTTGCGTCGCCACAAGATGAAGTTGAAGACTGCATTCAGTGGTGGAGTAAGTTGCTA GAAACAACGGAGGATGGGGAATTAGGAAACCTATTCGAGGAGGCCCAACAAATTGGAAATACTACAGAGAACCIC IACITTCA AT CAGGIACA GTAGAAAGGAGAGATGGGTTTTGGATGCCATGGAAGGGAATTTGGTTGCTTGTGGG CAAGCTGACAGCGCGCTAGTGACAAAGCATGTGGTTAAAGGAAAATGCCCTTATTTTTCACAATATCTCTCATTG CACAATGAAGCAAAACAGTTCTTTGAGCCATTGATGGGGGCATACCAGCCAAGCCGGTTAAATAAAGACGCTTTC AAGAAAGATTTCTTTAAATACAACAAACCGGTAGTTTTGAATGAAGTTGATTTTAACGCTTTCGAGAAAGCAGTT GAGGGAGTGATAACAATGATGGTTGACTTTGAATTCGCAGAATGCTTGTTTGTAACTGATCCTGATGAAATTTAT GGATCCCTGAACATGAAAGCCGCTGTTGGTGCTCAATACAAAGGAAAGAAACAGGATTACTTTTCTGGCATGGAT AGTTTTGATAAGGAGCGCCTGTTGTACCTTAGCTGTGAGAGGCTGTTCAATGGAGAGAAGGGAATTTGGAATGGT TCTCTAAAGGCGGAGTTGAGACCAATTGAGAAAGTGCAGGCAAACAAAACTAGAACATTTACAGCAGCACCGATT GACACATTACTTGGAGCCAAAGTTTGCGTTGATGACTTCAATAATCAATTCTACAGCTTCAACTTAAAATGTCCA TGGACAGTTGGCATGACTAAGTTTTATGGGGGTTGGGATAAGCTAATGAGGAGTTTACCTGATGGTTGGACATAT TGCCATGCAGATGGTTCACAGTTCGACAGTTCTTTAACTCCCTTGTTGTTGAATGCTGTCCTCAGTATTAGATGT TGCTTCATGGAAGATTGGTGGGTTGGAAAGGAAATGCTTGAAAACCTTTACGCTGAAATAGTTTACACACCAATC TTAGCGCCTGATGGCACATAA
} 


\section{>Ros $1-t e v-\mathrm{NIb}_{200}$}

ATGGAAAAGAATTGTGTGGAGTGAGAAAAGGTACTTGGACCAAAGAAGAAGACACTCTCTTGAGGCAATGTATA GAAGAGTATGGTGAAGGGAAATGGCATCAAGTTCCACACAGAGCAGGGTTGAACCGGTGTAGGAAGAGTTGCAGG CTGAGGTGGTTGAATTATCTGAGGCCAAATATCAAAAGAGGTCGGTTTTCGAGAGATGAAGTGGACCTAATTGTG AGGCTTCATAAGCTGTTGGGTAACAAATGGTCGCTGATTGCTGGTAGAATTCCTGGAAGGACAGCTAATGACGTG AAGAACTTTTGGAATACTCATGTGGGGAAGAATTTAGGCGAGGATGGAGAACGATGCCGGAAAAATGTTATGAAC ACAAAAACCATTAAGCTGACTAATATCGTAAGACCCCGAGCTCGGACCTTCACCGGATTGCACGTTACTTGGCCG AGAGAAGTCGGAAAAACCGATGAATTTCAAATGTCCGGTTAACAACTGATGAGATTCCAGATTGTGAGAAGCAA ACGCAATTTTACAATGATGTTGCGTCGCCACAAGATGAAGTTGAAGACTGCATTCAGTGGTGGAGTAAGTTGCTA GAAACAACGGAGGATGGGGAATTAGGAAACCTATTCGAGGAGGCCCAACAAATTGGAAATACTACACAGAACCIC TACTTCA AT CAGGACAAGTAGAAAGGAGAGATGGGTTTTGGATGCCATGGAAGGGAATTTGGTTGCTTGTGGG CAAGCTGACAGCGCGCTAGTGACAAAGCATGTGGTTAAAGGAAAATGCCCTTATTTTTCACAATATCTCTCATTG CACAATGAAGCAAAACAGTTCTTTGAGCCATTGATGGGGGCATACCAGCCAAGCCGGTTAAATAAAGACGCTTTC AAGAAAGATTTCTTTAAATACAACAAACCGGTAGTTTTGAATGAAGTTGATTTTAACGCTTTCGAGAAAGCAGTT GAGGGAGTGATAACAATGATGGTTGACTTTGAATTCGCAGAATGCTTGTTTGTAACTGATCCTGATGAAATTTAT GGATCCCTGAACATGAAAGCCGCTGTTGGTGCTCAATACAAAGGAAAGAAACAGGATTACTTTTCTGGCATGGAT AGTTTTGATAAGGAGCGCCTGTTGTACCTTAGCTGTGAGAGGCTGTTCAATGGAGAGAAGGGAATTTGGAATGGT TCTCTAAAGGCGGAGTTGAGACCAATTGAGAAAGTGCAGGCAAACAAAACTAGAACATTTACAGCAGCACCGATT GACACATTACTTGGAGCCTAA

\section{$>$ Ros $1-$ tev-NIb 100}

ATGGAAAAGAATGTCGTGGAGTGAGAAAAGGTACTTGGACCAAAGAAGAAGACACTCTCTTGAGGCAATGTATA GAAGAGTATGGTGAAGGGAAATGGCATCAAGTTCCACACAGAGCAGGGTTGAACCGGTGTAGGAAGAGTTGCAGG CTGAGGTGGTTGAATTATCTGAGGCCAAATATCAAAAGAGGTCGGTTTTCGAGAGATGAAGTGGACCTAATTGTG AGGCTTCATAAGCTGTTGGGTAACAAATGGTCGCTGATTGCTGGTAGAATTCCTGGAAGGACAGCTAATGACGTG AAGAACTTTTGGAATACTCATGTGGGGAAGAATTTAGGCGAGGATGGAGAACGATGCCGGAAAAATGTTATGAAC ACAAAAACCATTAAGCTGACTAATATCGTAAGACCCCGAGCTCGGACCTTCACCGGATTGCACGTTACTTGGCCG AGAGAAGTCGGAAAAACCGATGAATTTTCAAATGTCCGGTTAACAACTGATGAGATTCCAGATTGTGAGAAGCAA ACGCAATTTTACAATGATGTTGCGTCGCCACAAGATGAAGTTGAAGACTGCATTCAGTGGTGGAGTAAGTTGCTA GAAACAACGGAGGATGGGGAATTAGGAAACCTATTCGAGGAGGCCCAACAAATTGGAAATACTACAGAGAACCIC TACITTCA AT CAGEIACAAGTAGAAAGGAGAGATGGGTTTTGGATGCCATGGAAGGGAATTTGGTTGCTTGTGGG CAAGCTGACAGCGCGCTAGTGACAAAGCATGTGGTTAAAGGAAAATGCCCTTATTTTTCACAATATCTCTCATTG CACAATGAAGCAAAACAGTTCTTTGAGCCATTGATGGGGGCATACCAGCCAAGCCGGTTAAATAAAGACGCTTTC AAGAAAGATTTCTTTAAATACAACAAACCGGTAGTTTTGAATGAAGTTGATTTTAACGCTTTCGAGAAAGCAGTT GAGGGAGTGATAACAATGTAA

\section{$>$ Ros1-tev-NIb 50}

ATGGAAAAGAATTGTCGTGGAGTGAGAAAAGGTACTTGGACCAAAGAAGAAGACACTCTCTTGAGGCAATGTATA GAAGAGTATGGTGAAGGGAAATGGCATCAAGTTCCACACAGAGCAGGGTTGAACCGGTGTAGGAAGAGTTGCAGG CTGAGGTGGTTGAATTATCTGAGGCCAAATATCAAAAGAGGTCGGTTTTCGAGAGATGAAGTGGACCTAATTGTG AGGCTTCATAAGCTGTTGGGTAACAAATGGTCGCTGATTGCTGGTAGAATTCCTGGAAGGACAGCTAATGACGTG AAGAACTTTTGGAATACTCATGTGGGGAAGAATTTAGGCGAGGATGGAGAACGATGCCGGAAAAATGTTATGAAC ACAAAAACCATTAAGCTGACTAATATCGTAAGACCCCGAGCTCGGACCTTCACCGGATTGCACGTTACTTGGCCG AGAGAAGTCGGAAAAACCGATGAATTTCAAATGTCCGGTTAACAACTGATGAGATTCCAGATTGTGAGAAGCAA ACGCAATTTTACAATGATGTTGCGTCGCCACAAGATGAAGTTGAAGACTGCATTCAGTGGTGGAGTAAGTTGCTA GAAACAACGGAGGATGGGGAATTAGGAAACCTATTCGAGGAGGCCCAACAAATTGGAAATACIACAGAGAACCIC HACITICAT AAGGACAAGTAGAAAGGAGAGATGGGTTTTGGATGCCATGGAAGGGAATTTGGTTGCTTGTGGG CAAGCTGACAGCGCGCTAGTGACAAAGCATGTGGTTAAAGGAAAATGCCCTTATTTTTCACAATATCTCTCATTG CACAATGAAGCAAAACAGTAA

\section{>Ros1-tev-NIb 25}

ATGGAAAAGATTGTCGTGGAGTGAGAAAAGGTACTTGGACCAAAGAAGAAGACACTCTCTTGAGGCAATGTATA GAAGAGTATGGTGAAGGGAAATGGCATCAAGTTCCACACAGAGCAGGGTTGAACCGGTGTAGGAAGAGTTGCAGG CTGAGGTGGTTGAATTATCTGAGGCCAAATATCAAAAGAGGTCGGTTTTCGAGAGATGAAGTGGACCTAATTGTG AGGCTTCATAAGCTGTTGGGTAACAAATGGTCGCTGATTGCTGGTAGAATTCCTGGAAGGACAGCTAATGACGTG AAGAACTTTTGGAATACTCATGTGGGGAAGAATTTAGGCGAGGATGGAGAACGATGCCGGAAAAATGTTATGAAC ACAAAAACCATTAAGCTGACTAATATCGTAAGACCCCGAGCTCGGACCTTCACCGGATTGCACGTTACTTGGCCG AGAGAAGTCGGAAAAACCGATGAATTTCAAATGTCCGGTTAACAACTGATGAGATTCCAGATTGTGAGAAGCAA ACGCAATTTTACAATGATGTTGCGTCGCCACAAGATGAAGTTGAAGACTGCATTCAGTGGTGGAGTAAGTTGCTA GAAACAACGGAGGATGGGGAATTAGGAAACCTATTCGAGGAGGCCCAACAAATTGGAAATACTACAGAGAACCTC 
TACITICA AT CAGGIACA GTAGAAAGGAGAGATGGGTTTTGGATGCCATGGAAGGGAATTTGGTTGCTTGTGGG CAAGCTGACAGCGCGCTATAA

\begin{abstract}
$>$ Ros1-tvmv-NIb 100
ATGGAAAAGAATGTCGTGGAGTGAGAAAAGGTACTTGGACCAAAGAAGAAGACACTCTCTTGAGGCAATGTATA GAAGAGTATGGTGAAGGGAAATGGCATCAAGTTCCACACAGAGCAGGGTTGAACCGGTGTAGGAAGAGTTGCAGG CTGAGGTGGTTGAATTATCTGAGGCCAAATATCAAAAGAGGTCGGTTTTCGAGAGATGAAGTGGACCTAATTGTG AGGCTTCATAAGCTGTTGGGTAACAAATGGTCGCTGATTGCTGGTAGAATTCCTGGAAGGACAGCTAATGACGTG AAGAACTTTTGGAATACTCATGTGGGGAAGAATTTAGGCGAGGATGGAGAACGATGCCGGAAAAATGTTATGAAC ACAAAAACCATTAAGCTGACTAATATCGTAAGACCCCGAGCTCGGACCTTCACCGGATTGCACGTTACTTGGCCG AGAGAAGTCGGAAAAACCGATGAATTTTCAAATGTCCGGTTAACAACTGATGAGATTCCAGATTGTGAGAAGCAA ACGCAATTTTACAATGATGTTGCGTCGCCACAAGATGAAGTTGAAGACTGCATTCAGTGGTGGAGTAAGTTGCTA GAAACAACGGAGGATGGGGAATTAGGAAACCTATTCGAGGAGGCCCAACAAATTGGAAAT AGTAGAAAGGAGAGATGGGTTTTGGATGCCATGGAAGGGAATTTGGTTGCTTGTGGG CAAGCTGACAGCGCGCTAGT GACAAAGCATGTGGTTAAAGGAAAATGCCCTTATTTTTCACAATATCTCTCATTG CACAATGAAGCAAAACAGTTCTTTGAGCCATTGATGGGGGCATACCAGCCAAGCCGGTTAAATAAAGACGCTTTC AAGAAAGATTTCTTTAAATACAACAAACCGGTAGTTTTGAATGAAGTTGATTTTAACGCTTTCGAGAAAGCAGTT GAGGGAGTGATAACAATGTAA
\end{abstract}

\title{
$>$ Ros $1-t v m v-t e v-N I b_{100}$
}

ATGGAAAAGAATGTCGTGGAGTGAGAAAAGGTACTTGGACCAAAGAAGAAGACACTCTCTTGAGGCAATGTATA GAAGAGTATGGTGAAGGGAAATGGCATCAAGTTCCACACAGAGCAGGGTTGAACCGGTGTAGGAAGAGTTGCAGG CTGAGGTGGTTGAATTATCTGAGGCCAAATATCAAAAGAGGTCGGTTTTCGAGAGATGAAGTGGACCTAATTGTG AGGCTTCATAAGCTGTTGGGTAACAAATGGTCGCTGATTGCTGGTAGAATTCCTGGAAGGACAGCTAATGACGTG AAGAACTTTTGGAATACTCATGTGGGGAAGAATTTAGGCGAGGATGGAGAACGATGCCGGAAAAATGTTATGAAC ACAAAAACCATTAAGCTGACTAATATCGTAAGACCCCGAGCTCGGACCTTCACCGGATTGCACGTTACTTGGCCG AGAGAAGTCGGAAAAACCGATGAATTTTCAAATGTCCGGTTAACAACTGATGAGATTCCAGATTGTGAGAAGCAA ACGCAATTTTACAATGATGTTGCGTCGCCACAAGATGAAGTTGAAGACTGCATTCAGTGGTGGAGTAAGTTGCTA GAAACAACGGAGGATGGGGAATTAGGAAACCTATTCGAGGAGGCCCAACAAATTGGAAAT

AA IA GATACACHACAGAGACCICIACITHCA ATCAGGIACAAGTAGAAAGGAGAGATGGGTTTG GATGCCATGGAAGGGAATTTGGTTGCTTGTGGGCAAGCTGACAGCGCGCTAGTGACAAAGCATGTGGTTAAAGGA AAATGCCCTTATTTTTCACAATATCTCTCATTGCACAATGAAGCAAAACAGTTCTTTGAGCCATTGATGGGGGCA TACCAGCCAAGCCGGTTAAATAAAGACGCTTTCAAGAAAGATTTCTTTAAATACAACAAACCGGTAGTTTTGAAT GAAGTTGATTTTAACGCTTTCGAGAAAGCAGTTGAGGGAGTGATAACAATGTAA

\begin{abstract}
$>\mathrm{NIb}_{100}-t e v-$ Ros $1-t v m v-\mathrm{NIb}_{100}$
ATGAGTAGAAAGGAGAGATGGGTTTTGGATGCCATGGAAGGGAATTTGGTTGCTTGTGGGCAAGCTGACAGCGCG CTAGTGACAAAGCATGTGGTTAAAGGAAAATGCCCTTATTTTTCACAATATCTCTCATTGCACAATGAAGCAAAA CAGTTCTTTGAGCCATTGATGGGGGCATACCAGCCAAGCCGGTTAAATAAAGACGCTTTCAAGAAAGATTTCTTT AAATACAACAAACCGGTAGTTTTGAATGAAGTTGATTTTAACGCTTTCGA GAAAGCAGTTGAGGGAGTGATAACA ATGACTACAGAGAACCICIACIITCAATCAGGIACAATGGAAAAGAATTGTCGTGGAGTGAGAAAAGGTACTTGG ACCAAAGAAGAAGACACTCTCTTGAGGCAATGTATAGAAGAGTATGGTGAAGGGAAATGGCATCAAGTTCCACAC AGAGCAGGGTTGAACCGGTGTAGGAAGAGTTGCAGGCTGAGGTGGTTGAATTATCTGAGGCCAAATATCAAAAGA GGTCGGTTTTCGAGAGATGAAGTGGACCTAATTGTGAGGCTTCATAAGCTGTTGGGTAACAAATGGTCGCTGATT GCTGGTAGAATTCCTGGAAGGACAGCTAATGACGTGAAGAACTTTTGGAATACTCATGTGGGGAAGAATTTAGGC GAGGATGGAGAACGATGCCGGAAAAATGTTATGAACACAAAAACCATTAA GCTGACTAATATCGTAAGACCCCGA GCTCGGACCTTCACCGGATTGCACGTTACTTGGCCGAGAGAAGTCGGAAAAACCGATGAATTTTCAAATGTCCGG TTAACAACTGATGAGATTCCAGATTGTGAGAAGCAAACGCAATTTACAATGATGTTGCGTCGCCACAAGATGAA GTTGAAGACTGCATTCAGTGGTGGAGTAAGTTGCTAGAAACAACGGAGGATGGGGAATTAGGAAACCTATTCGAG GAGGCCCAACAAATTGGAAAT TGCGIGAAACTGTGAGATIAA AIGATACA ATAGAAAGGAGAGATGGGTT TTGGATGCCATGGAAGGGAATTTGGTTGCTTGTGGGCAAGCTGACAGCGCGCTAGTGACAAAGCATGTGGTTAAA GGAAAATGCCCTTATTTTTCACAATATCTCTCATTGCACAATGAAGCAAAACAGTTCTTTGAGCCATTGATGGGG GCATACCAGCCAAGCCGGTTAAATAAAGACGCTTTCAAGAAAGATTTCTTTAAATACAACAAACCGGTAGTTTTG AATGAAGTTGATTTTAACGCTTTCGAGAAAGCAGTTGAGGGAGTGATAACAATGTAA
\end{abstract}

Figure S4. Sequences of the constructs to singly express TEV and TVMV NIaPros and to coexpress both proteases in plant tissues. TEV (DQ986288) and TVMV (NC_001768) NIaPro coding regions are in black, flanked by an initiator ATG codon in green and a TAA stop codon in red. These proteins were expressed using plasmid pG53CPMVZ (see SI Figure S5) under the 
control of CaMV 35S promoter (in red) and terminator (in fuchsia) with the modified 5' and 3' UTR of CPMV RNA-2 (in green). Co-expression of both proteases was achieved inserting two independent expression cassettes between the borders of the A. tumefaciens T-DNA.

\begin{abstract}
$>$ TEV NIaPro
GATTCCATTGCCCAGCTATCTGTCACTTTATTGTGAAGATAGTGGAAAAGGAAGGTGGCTCCTACAAATGCCATC ATTGCGATAAAGGAAAGGCCATCGTTGAAGATGCCTCTGCCGACAGTGGTCCCAAAGATGGACCCCCACCCACGA GGAGCATCGTGGAAAAAGAAGACGTTCCAACCACGTCTTCAAAGCAAGTGGATTGATGTGATATCTCCACTGACG TAAGGGATGACGCACAATCCCACTATCCTTCGCAAGACCCTTCCTCTATATAAGGAAGTTCATTTCATTTGGAGA GGTATTAAAATCTTAATAGGTTTTGATAAAAGCGAACGTGGGGAAACCCGAACCAAACCTTCTTCTAAACTCTCT СTCATCTCTCTTAAAGCAAACTTCTCTCTTGTCTTTCTTGCGTGAGCGATCTTCAACGTTGTCAGATCGTGCTTC GGCACCAGTACAACGTTTTCTTTCACTGAAGCGAAATCAAAGATCTCTTTGTGGACACGTAGTGCGGCGCCATTA AATAACGTGTACTTGTCCTATTCTTGTCGGTGTGGTCTTGGGAAAAGAAAGCTTGCTGGAGGCTGCTGTTCAGCC CCATACATTACTTGTTACGATTCTGCTGACTTTCGGCGGGTGCAATATCTCTACTTCTGCTTGACGAGGTATTGT TGCCTGTACTTCTTCTTCTTCTCTTGCTGATTGGTCTATAAGAAATCTAGTATTTTCTTTGAAACAGAGTTT TCCCGTGGTTTCGAACTTGGAGAAAGATTGTAAGCTTCTGTATATTCTGCCCAAATTTGAAATGGGAGAAAGC TTGTTTAAGGGACCACGTGATTACAACCCGATATCGAGCACCATTTGTCACTTGACGAATGAATCTGATGGGCAC ACAACATCGTTGTATGGTATTGGATTTGGTCCCTTCATCATTACAAACAAGCACTTGTTTAGAAGAAATAATGGA ACACTGTTGGTCCAATCACTACATGGTGTATTCAAGGTCAAGAACACCACGACTTTGCAACAACACCTCATTGAT GGGAGGGACATGATAATTATTCGCATGCCTAAGGATTTCCCACCATTTCCTCAAAAGCTGAAATTTAGAGAGCCA CAAAGGGAAGAGCGCATATGTCTTGTGACAACCAACTTCCAAACTAAGAGCATGTCTAGCATGGTGTCAGACACT AGTTGCACATTCCCTTCATCTGATGGCATATTCTGGAAGCATTGGATTCAAACCAAGGATGGGCAGTGTGGCAGT CCATTAGTATCAACTAGAGATGGGTTCATTGTTGGTATACACTCAGCATCGAATTTCACCAACACAAACAATTAT TTCACAAGCGTGCCGAAAAACTTCATGGAATTGTTGACAAATCAGGAGGCGCAGCAGTGGGTTAGTGGTTGGCGA TTAAATGCTGACTCAGTATTGTGGGGGGGCCATAAAGTTTTCATGAGCAAACCTGAAGAGCCTTTTCAGCCAGTT AAGGAAGCGACTCAACTCATGAGTGAATTGGTGTACTCGCAATAACTCTGGTTTCATTAAATTTTCTTTAGTTTG AATTTACTGTTATTCGGTTGCATTTCTATGTTTGGTGAGCGTTTTCTGTGCTCAGAGTGTGTTTATTTTATGT AАTTTAATTTCTTTGTGAGCTCCTGTTTAGCAGGTCGTCCCTTCAGCAAGGACACAAAAAGATTTTAATTTTATT CGCTGAAATCACCAGTCTCTCTCTACAAATCTATCTCTCTCTATTTTCTCCATAAATAATGTGTGAGTAGTTTCC CGATAAGGGAAATTAGGGTTCTTATAGGGTTTCGCTCATGTGTTGAGCATATAAGAAACCCTTAGTATGTATTTG TATTTGTAAAATACTTCTATCAATAAAATTTCTAATTCCTAAAACCAAAATCCAG
\end{abstract}

\title{
>TVMV NIaPro
}

GATTCCATTGCCCAGCTATCTGTCACTTTATTGTGAAGATAGTGGAAAAGGAAGGTGGCTCCTACAAATGCCATC ATTGCGATAAAGGAAAGGCCATCGTTGAAGATGCCTCTGCCGACAGTGGTCCCAAAGATGGACCCCCACCCACGA GGAGCATCGTGGAAAAAGAAGACGTTCCAACCACGTCTTCAAAGCAAGTGGATTGATGTGATATCTCCACTGACG TAAGGGATGACGCACAATCCCACTATCCTTCGCAAGACCCTTCCTCTATATAAGGAAGTTCATTTCATTTGGAGA GGTATTAAAATCTTAATAGGTTTTGATAAAAGCGAACGTGGGGAAACCCGAACCAAACCTTCTTCTAAACTCTCT CTCATCTCTCTTAAAGCAAACTTCTCTCTTGTCTTTCTTGCGTGAGCGATCTTCAACGTTGTCAGATCGTGCTTC GGCACCAGTACAACGTTTTCTTTCACTGAAGCGAAATCAAAGATCTCTTTGTGGACACGTAGTGCGGCGCCATTA AATAACGTGTACTTGTCCTATTCTTGTCGGTGTGGTCTTGGGAAAAGAAAGCTTGCTGGAGGCTGCTGTTCAGCC CCATACATTACTTGTTACGATTCTGCTGACTTTCGGCGGGTGCAATATCTCTACTTCTGCTTGACGAGGTATTGT TGCCTGTACTTCTTCTTCTTCTTCTTGCTGATTGGTTCTATAAGAAATCTAGTATTTTCTTTGAAACAGAGTTT TCCCGTGGTTTTCAACTTGGAGAAAGATGTTAAGCTTCTGTATATTCTGCCCAAATTTGAAATGTCAAAGGCG CTACTTAAGGGAGTGCGAGATTTTAATCCAATCTCTGCTTGCGTATGGCTCCTTGAGAACTCCTCGGATGGGCAT AGTGAGAGACTGTTTGGCATTGGTTTTGGCCCATATATCATTGCCAACCAACATCTTTTTAGAAGGAACAATGGA GAGTTGACTATCAAAACCATGCATGGTGAGTTCAAAGTCAAGAACTCAACACAATTGCAGATGAAACCAGTTGAG GGCAGAGACATAATAGTTATCAAAATGGCTAAGGACTTCCCACCATTCCCTCAAAAACTAAAATTCAGACAGCCT ACCATCAAAGATAGAGTGTGCATGGTATCCACAAATTTCAGCAGAAAAGTGTCTCTAGTCTAGTGTCTGAGTCA TCACACATTGTGCATAAAGA GGACACTTCATTCTGGCAACACTGGATAACAACAAAGGATGGACAATGTGGAAGT CCGCTGGTTTCAATCATTGATGGAAATATTTTGGGGATCCACAGCCTGACGCATACGACCAATGGTAGCAATTAC TTCGTGGAATTTCCTGAGAAGTTCGTAGCTACATATCTTGATGCCGCTGATGGTTGGTGCAAGAATTGGAAGTTC AATGCTGATAAGATCAGTTGGGGTTCCTTTACATTAGTTGAGGATGCGCCCGAAGATGACTTCATGGCCAAGAAA ACTGTTGCCGCCATCATGGACGATTTGGTCCGCACTCAATAACTCTGGTTTCATTAAATTTTCTTTAGTTTGAAT TTACTGTTATTCGGTGTGCATTTCTATGTTTGGTGAGCGGTTTTCTGTGCTCAGAGTGTGTTTATTTTATGTAAT TTAATTTCTTTGTGAGCTCCTGTTTAGCAGGTCGTCCCTTCAGCAAGGACACAAAAAGATTTTAATTTTATTCGC TGAAATCACCAGTCTCTCTCTACAAATCTATCTCTCTCTATTTTCTCCATAAATAATGTGTGAGTAGTTTCCCGA TAAGGGAAATAGGGTTCTTATAGGGTTTCGCTCATGTGTTGAGCATATAAGAAACCCTTAGTATGTATTTGTAT TTGTAAAATACTTCTATCAATAAAATTCTAATTCTAAAACCAAAATCCAG 


\section{>TVMV+TEV NIaPro}

GATTCCATTGCCCAGCTATCTGTCACTTTATTGTGAAGATAGTGGAAAAGGAAGGTGGCTCCTACAAATGCCATC ATTGCGATAAAGGAAAGGCCATCGTTGAAGATGCCTCTGCCGACAGTGGTCCCAAAGATGGACCCCCACCCACGA GGAGCATCGTGGAAAAAGAAGACGTTCCAACCACGTCTTCAAAGCAAGTGGATTGATGTGATATCTCCACTGACG TAAGGGATGACGCACAATCCCACTATCCTTCGCAAGACCCTTCCTCTATATAAGGAAGTTCATTTCATTTGGAGA GGTATTAAAATCTTAATAGGTTTTGATAAAAGCGAACGTGGGGAAACCCGAACCAAACCTTCTTCTAAACTCTCT CTCATCTCTCTTAAAGCAAACTTCTCTCTTGTCTTTCTTGCGTGAGCGATCTTCAACGTTGTCAGATCGTGCTTC GGCACCAGTACAACGTTTTCTTTCACTGAAGCGAAATCAAAGATCTCTTTGTGGACACGTAGTGCGGCGCCATTA AATAACGTGTACTTGTCCTATTCTTGTCGGTGTGGTCTTGGGAAAAGAAAGCTTGCTGGAGGCTGCTGTTCAGCC CCATACATTACTTGTTACGATTCTGCTGACTTTCGGCGGGTGCAATATCTCTACTTCTGCTTGACGAGGTATTGT TGCCTGTACTTCTTCTTCTTCTTCTTGCTGATTGGTCTATAAGAAATCTAGTATTTTCTTTGAAACAGAGTTT TCCCGTGGTTTTCAACTTGGAGAAAGATTGTAAGCTTCTGTATATTCTGCCCAAATTTGAAATGTCAAAGGCG CTACTTAAGGGAGTGCGAGATTTTAATCCAATCTCTGCTTGCGTATGGCTCCTTGAGAACTCCTCGGATGGGCAT AGTGAGAGACTGTTTGGCATTGGTTTTGGCCCATATATCATTGCCAACCAACATCTTTTTAGAAGgAACAATGGA GAGTTGACTATCAAAACCATGCATGGTGAGTTCAAAGTCAAGAACTCAACACAATTGCAGATGAAACCAGTTGAG GGCAGAGACATAATAGTTATCAAAATGGCTAAGGACTTCCCACCATTCCCTCAAAAACTAAAATTCAGACAGCCT ACCATCAAAGATAGAGTGTGCATGGTATCCACAAATTTTCAGCAGAAAAGTGTCTCTAGTCTAGTGTCTGAGTCA TCACACATTGTGCATAAAGA GGACACTTCATTCTGGCAACACTGGATAACAACAAAGGATGGACAATGTGGAAGT CCGCTGGTTTCAATCATTGATGGAAATATTTTGGGGATCCACAGCCTGACGCATACGACCAATGGTAGCAATTAC TTCGTGGAATTTCCTGAGAAGTTCGTAGCTACATATCTTGATGCCGCTGATGGTTGGTGCAAGAATTGGAAGTTC AATGCTGATAAGATCAGTTGGGGTTCCTTTACATTAGTTGAGGATGCGCCCGAAGATGACTTCATGGCCAAGAAA ACTGTTGCCGCCATCATGGACGATTTGGTCCGCACTCAATAACTCTGGTTTCATTAAATTTTCTTTAGTTTGAAT TTACTGTTATTCGTGTGCATTTCTATGTTTGGTGAGCGGTTTTCTGTGCTCAGAGTGTGTTTATTTTATGTAAT TTAATTCTTTGTGAGCTCCTGTTTAGCAGGTCGTCCCTTCAGCAAGGACACAAAAAGATTTTAATTTTATTCGC TGAAATCACCAGTCTCTCTCTACAAATCTATCTCTCTCTATTTTCTCCATAAATAATGTGTGAGTAGTTTCCCGA TAAGGGAAATTAGGGTTCTTATAGGGTTTCGCTCATGTGTTGAGCATATAAGAAACCCTTAGTATGTATTTGTAT TTGTAAAATACTTCTATCAATAAAATTTCTAATTCCTAAAACCAAAATCCAGGCGGCCGCGATTCCATTGCCCAG CTATCTGTCACTTTATTGTGAAGATAGTGGAAAAGGAAGGTGGCTCCTACAAATGCCATCATTGCGATAAAGGAA AGGCCATCGTTGAAGATGCCTCTGCCGACAGTGGTCCCAAAGATGGACCCCCACCCACGAGGAGCATCGTGGAAA AAGAAGACGTTCCAACCACGTCTTCAAAGCAAGTGGATTGATGTGATATCTCCACTGACGTAAGGGATGACGCAC AATCCCACTATCCTTCGCAA GACCCTTCCTCTATATAAGGAAGTTCATTTCATTTGGAGAGGTATTAAAATCTTA ATAGGTTTTGATAAAAGCGAACGTGGGGAAACCCGAACCAAACCTTCTTCTAAACTCTCTCTCATCTCTCTTAAA GCAAACTTCTCTCTTGTCTTTCTTGCGTGAGCGATCTTCAACGTTGTCAGATCGTGCTTCGGCACCAGTACAACG TTTTCTTTCACTGAAGCGAAATCAAAGATCTCTTTGTGGACACGTAGTGCGGCGCCATTAAATAACGTGTACTTG TCCTATTCTTGTCGGTGTGGTCTTGGGAAAAGAAAGCTTGCTGGAGGCTGCTGTTCAGCCCCATACATTACTTGT TACGATTCTGCTGACTTTCGGCGGGTGCAATATCTCTACTTCTGCTTGACGAGGTATTGTTGCCTGTACTTCTTT CTTCTTCTTCTTGCTGATTGGTTCTATAAGAAATCTAGTATTTTCTTTGAAACAGAGTTTTCCCGTGGTTTTCGA ACTTGGAGAAAGATTGTTAAGCTTCTGTATATTCTGCCCAAATTTGAAATGGGAGAAAGCTTGTTTAAGGGACCA CGTGATTACAACCCGATATCGAGCACCATTTGTCACTTGACGAATGAATCTGATGGGCACACAACATCGTTGTAT GGTATTGGATTTGGTCCCTTCATCATTACAAACAAGCACTTGTTTAGAAGAAATAATGGAACACTGTTGGTCCAA TCACTACATGGTGTATTCAA GGTCAAGAACACCACGACTTTGCAACAACACCTCATTGATGGGAGGGACATGATA ATTATTCGCATGCCTAAGGATTTCCCACCATTTCCTCAAAAGCTGAAATTTAGAGAGCCACAAAGGGAAGAGCGC ATATGTCTTGTGACAACCAACTTCCAAACTAAGAGCATGTCTAGCATGGTGTCAGACACTAGTTGCACATTCCCT TCATCTGATGGCATATTCTGGAAGCATTGGATTCAAACCAAGGATGGGCAGTGTGGCAGTCCATTAGTATCAACT AGAGATGGGTTCATTGTTGGTATACACTCAGCATCGAATTTCACCAACACAAACAATTATTTCACAAGCGTGCCG AAAAACTTCATGGAATTGTTGACAAATCAGGAGGCGCAGCAGTGGGTTAGTGGTTGGCGATTAAATGCTGACTCA GTATTGTGGGGGGGCCATAAAGTTTTCATGAGCAAACCTGAAGAGCCTTTTCAGCCAGTTAAGGAAGCGACTCAA CTCATGAGTGAATTGGTGTACTCGCAATAACTCTGGTTTCATTAAATTTCTTTAGTTTGAATTTACTGTTATTC GGTGTGCATTTCTATGTTTGGTGAGCGGTTTTCTGTGCTCAGAGTGTGTTTATTTTATGTAATTTAATTTCTTTG TGAGCTCCTGTTTAGCAGGTCGTCCCTTCAGCAAGGACACAAAAAGATTTTAATTTTATTCGCTGAAATCACCAG TCTCTCTCTACAAATCTATCTCTCTCTATTTTCTCCATAAATAATGTGTGAGTAGTTTCCCGATAAGGGAAATTA GGGTTCTTATAGGGTTTCGCTCATGTGTTGAGCATATAAGAAACCCTTAGTATGTATTTGTATTTGTAAAATACT TCTATCAATAАAАTTCTAАTTCCTAAAАCCAAAATCCAG

Figure S5. Sequence of expression vector pG53CPMVZ used to express in plant tissues the synthetic reporter constructs, as well as the potyviral NIaPros. The plasmid that derives from CLEAN-G181 (GenBank accession number EU186083) contains, between the left and right borders of the T-DNA, a CaMV 35S promoter (in red), a modified version of CPMV RNA-2 
5' UTR (in green), a polylinker consisting of two BsaI sites (yellow background) separated by a LacZ spacer (in blue italics), CPMV RNA-2 3' UTR (in green) and CaMV 35S terminator (in fuchsia). See the Supplementary Fig. S6 of Cordero et al. 2017 (Mol. Plant Microb. Interact. 30: 63-71) for more details.

GCGGCCGCGATTCCATTGCCCAGСTATCTGTCACTTTATTGTGAAGATAGTGGAAAAGGAAGGTGGCTCCTACAA ATGCCATCATTGCGATAAAGGAAAGGCCATCGTTGAAGATGCCTCTGCCGACAGTGGTCCCAAAGATGGACCCCC ACCCACGAGGAGCATCGTGGAAAAAGAAGACGTTCCAACCACGTCTTCAAAGCAAGTGGATTGATGTGATATCTC CACTGACGTAAGGGATGACGCACAATCCCACTATCCTTCGCAAGACССTTCСTCTATATAAGGAAGTTCATTTCA TTTGGAGAGGTATTAAAATCTTAATAGGTTTTGATAAAAGCGAACGTGGGGAAACCCGAACCAAACCTTCTTCTA

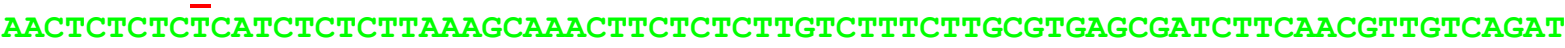
CGTGCTTCGGCACCAGTACAACGTTTTCTTTCACTGAAGCGAAATCAAAGATCTCTTTGTGGACACGTAGTGCGG CGССАTTAAATAACGTGTACTTGTCСTATTCTTGTCGGTGTGGTCTTGGGAAAAGAAAGCTTGCTGGAGGCTGCT GTTCAGCCCСАTACATTACTTGTTACGATTCTGCTGACTTTCGGCGGGTGCAATATCTCTACTTCTGCTTGACGA GGTATTGTTCCTGTACTTCTTTCTCTTCTTCTTGCTGATTGGTCTATAAGAAATCTAGTATTTCTTTGAAA CAGAGTTTTCCCGTGGTTTTCGAACTTGGAGAAAGATTGTTAAGCTTCTGTATATTCTGCCCAAATTTGAAGGAG ACCGCGG GAAAGCGGGCAGTGAGCGCAACGCAATTAATGTGAGTTAGCTCACTCATTAGGCACCCCAGGCTTTAC ACTTTATGCTTCCGGCTCGTATGTTGTGTGGAATTGTGAGCGGATAACAATTTCACACAGGAAACAGCTATGACC ATGATTACGCCAAGCGCGCAATTAACCCTCACTAAAGGGAACAAAAGCTGGGTACCGGGCCCCCCCTCGAGGTCG ACGGTATCGATAAGCTTGATATCGAATTCCTGCAGCCCGGGGGATCCACTAGTTCTAGAGCGGCCGCCACCGCGG TGGAGCTCCAATTCGCCCTATAGTGAGTCGTATTACGCGCGCTCACTGGCCGTCGTTTTACAACGTCGTGACTGG GAAAACCCTGGCGTTACCCAACTTAATCGCCTTGCAGCACATCCCCCTTTCGCCAGCTGGCGTAATAGCGAAGAG GCCCGCACCGATCGCCCTTCCCAACAGTTGCGCAGCCTGAATGGCGAATGGGACGCGGGCGGGTCTCGCTCTGGT TTCATTAAATTTCTTTAGTTTGAATTTACTGTTATTCGGTGTCATTTCTATGTTTGGTGAGCGGTTTTCTGTG СTCAGAGTGTGTTATTTATGTAATTAATTCTTTGTGAGCTCCTGTTTAGCAGGTCGTCCCTTCAGCAAGGA

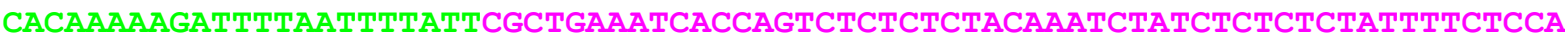
TAAATAATGTGTGAGTAGTTTCCCGATAAGGGAAATTAGGGTTCTTATAGGGTTTCGCTCATGTGTTGAGCATAT AAGAAACCCTTAGTATGTATTTGTATTTGTAAAATACTTCTATCAАTAАAАTTTCTAАTTCCTAAAАCCAАAАTC CAGGGGCCCTCGACGTTCCTTGACAGGATATATTGGCGGTAAACTAAGTCGCTGTATGTGTTTGTTTGAGATCC TCTAGGGCATGCAAGCTGATCTGGATCTCATGTGAGCAAAAGGCCAGCAAAAGGCCAGGAACCGTAAAAAGGCCG CGTTGCTGGCGTTTTTCCATAGGCTCCGCCCCCCTGACGAGCATCACAAAAATCGACGCTCAAGTCAGAGGTGGC GAAACCCGACAGGACTATAAAGATACCAGGCGTTTCCCCCTGGAAGCTCCCTCGTGCGCTCTCCTGTTCCGACCC TGCCGCTTACCGGATACCTGTCCGCCTTTCTCCCTTCGGGAAGCGTGGCGCTTTCTCATAGCTCACGCTGTAGGT ATCTCAGTTCGGTGTAGGTCGTTCGCTCCAAGCTGGGCTGTGTGCACGAACCCCCCGTTCAGCCCGACCGCTGCG CCTTATCCGGTAACTATCGTCTTGAGTCCAACCCGGTAAGACACGACTTATCGCCACTGGCAGCAGCCACTGGTA ACAGGATTAGCAGAGCGAGGTATGTAGGCGGTGCTACAGAGTTCTTGAAGTGGTGGCCTAACTACGGCTACACTA GAAGAACAGTATTTGGTATCTGCGCTCTGCTGAAGCCAGTTACCTTCGGAAGAAGAGTTGGTAGCTCTTGATCCG GCAAACAAACCACCGCTGGTAGCGGTGGTTTTTTTGTTTGCAAGCAGCAGATTACGCGCAGAAAAAAAGGATCTC AAGAAGATCCTTTGATCTTTTCTACGGGGTCTGACGCTCAGTGGAACGAAAACTCACGTTAAGGGATTTTGGTCA TGAGATTATCAAAAAGGATCTTCACCTAGATCCTTTTAAATTAAAAATGAAGTTTTAAATCAATCTAAAGTATAT ATGTGTAACATTGGTCTAGT GA TTAGAAAAACTCATCGAGCATCAAATGAAACTGCAATTTATTCATATCAGGAT TATCAATACCATATTTTTGAAAAAGCCGTTTCTGTAATGAAGGAGAAAACTCACCGAGGCAGTTCCATAGGATGG CAAGATCCTGGTATCGGTCTGCGATTCCGACTCGTCCAACATCAATACAACCTATTAATTTCCCCTCGTCAAAAA TAAGGTTATCAAGTGAGAAATCACCATGAGTGACGACTGAATCCGGTGAGAATGGCAAAAGTTTATGCATTTCTT TCCAGACTTGTTCAACAGGCCAGCCATTACGCTCGTCATCAAAATCACTCGCATCAACCAAACCGTTATTCATTC GTGATTGCGCCTGAGCGAGACGAAATACGCGATCGCTGTTAAAAGGACAATTACAAACAGGAATCGAATGCAACC GGCGCAGGAACACTGCCAGCGCATCAACAATATTTTCACCTGAATCAGGATATTCTTCTAATACCTGGAATGCTG TTTTCCCTGGGATCGCAGTGGTGAGTAACCATGCATCATCAGGAGTACGGATAAAATGCTTGATGGTCGGAAGAG GCATAAATTCCGTCAGCCAGTTTAGTCT GACCATCTCATCTGTAACAACATTGGCAACGCTACCTTTGCCATGTT TCAGAAACAACTCTGGCGCATCGGGCTTCCCATACAATCGGTAGATTGTCGCACCTGATTGCCCGACATTATCGC GAGCCCATTTATACCCATATAAATCAGCATCCATGTTGGAATTTAATCGCGGCCTTGAGCAAGACGTTTCCCGTT GAATATGGCTCATAACACCCCTTGTATTACTGTTTATGTAAGCAGACAGTTTTATTGTTCATGATGATATATTTT TATCTTGTGCAATGTAACATCAGAGATTTTGAGACACAACGTGGCTTTGTTGAATAAATCGAACTTTTGCTGAGT TGAAGGATCAGATCACGCATCTTCCCGACAACGCAGACCGTTCCGTGGCAAAGCAAAAGTTCAAAATCACCAACT GGTCCACCTACAACAAAGCTCTCATCAACCGTGGCTCCCTCACTTTCTGGCTGGATGATGGGGCGATTCAGGCGA TCCCCATCCAACAGCCCGCCGTCGAGCGGGCTTTTTTATCCCCGGAAGCCTGTGGATAGAGGGTAGTTATCCACG TGAAACCGCTAATGCCCCGCAAAGCCTTGATTCACGGGGCTTTCCGGCCCGCTCCAAAAACTATCCACGTGAAAT CGCTAATCAGGGTACGTGAAATCGCTAATCGGAGTACGTGAAATCGCTAATAAGGTCACGTGAAATCGCTAATCA 
AAAAGGCACGTGAGAACGCTAATAGCCCTTTCAGATCAACAGCTTGCAAACACCCCTCGCTCCGGCAAGTAGTTA CAGCAAGTAGTATGTTCAATTAGCTTTTCAATTATGAATATATATATCAATTATTGGTCGCCCTTGGCTTGTGGA CAATGCGCTACGCGCACCGGCTCCGCCCGTGGACAACCGCAAGCGGTTGCCCACCGTCGAGCGCCTTTGCCCACA ACCCGGCGGCCGGCCGCAACAGATCGTTTTATAAATTTTTTTTTTGAAAAAGAAAAAGCCCGAAAGGCGGCAAC CTCTCGGGCTTCTGGATTTCCGATCCCCGGAATTAGATCCGTTTAAACTACGTAAGATCGATCT TGGCAGGATAT ATTGTGGTGTAAAGTTCCTGCGGCGGTCGAGATGGATCTTGGCAGGATATATTGTGGTGTAAACGTTCCT 


\section{DISCUSIÓN}



Las plantas son un almacén de recursos para los seres humanos, tanto por su uso directo como alimento, fibras o combustible, como por ser fuente de productos naturales de interés farmacéutico e industrial. La biotecnología cuenta entre sus objetivos el convertir a las plantas en biofactorías capaces de aportar de manera sostenible productos de interés para el ser humano, incluyendo alimentos más saludables, forraje para el ganado, fármacos, productos para la industria química y combustibles. Las propiedades biológicas de los virus de plantas permiten desarrollar herramientas genéticas de expresión transitoria de diversas proteínas recombinantes de interés biotecnológico (Hefferon, 2012; Sainsbury and Lomonossof, 2014) (Wang et al., 2020). El conocimiento de la interacción planta-virus a nivel molecular ha permitido desarrollar vectores virales capaces de expresar eficientemente proteínas recombinantes en plantas (Gleba et al., 2007; Sainsbury et al., 2009; Sainsbury et al., 2010). Los virus de plantas son modificados para conseguir que transporten genes heterólogos hasta el interior de las células vegetales y desencadenen su expresión. De esta manera se consigue una producción rápida de las proteínas de interés en grandes cantidades en la planta huésped adecuada. En nuestro grupo de investigación se desarrolló un vector viral derivado del virus del grabado del tabaco (TEV) que expresa el gen marcador Roseal entre los cistrones NIb y CP de su genoma (Bedoya et al. 2012). La expresión de este factor de transcripción en plantas durante la infección viral abre un gran abanico de posibilidades para el estudio de los virus de plantas y su interacción con las plantas huésped. En esta tesis, el uso del factor de transcripción de tipo R2R3 MYB Rosea1 de Antirrhinum majus en diferentes clones infecciosos virales ha permitido monitorizar visualmente la infección viral debido a la síntesis de antocianinas y ha permitido explorar la gran versatilidad que ofrecen los virus de plantas en biotecnología.

Las antocianinas son un grupo de pigmentos flavonoides propios de las plantas. Su biosíntesis está controlada por tres factores de transcripción (de tipo MYB, bHLH y WD40), que forman un complejo ternario que activa la expresión de la mayoría de genes estructurales de la ruta (Zhang et al., 2014, Passeri et al., 2016) (Alappat and Alappat, 2020). El factor de transcripción MYB es el elemento limitante en la producción de antocianinas (Piazza et al., 2002; Schwinn et al., 2006; Albert et al., 2011), por tanto, la expresión de Rosea1 en plantas mediante virus relaciona las cantidad de antocianinas con el título viral (Bedoya et al., 2012). Las antocianinas son pigmentos hidrosolubles muy intensos y fácilmente detectables por el ojo humano, que se acumulan en las vacuolas de las células vegetales y originan muchos de los vívidos colores de flores, verduras y frutas. 
El ZYMV, patógeno de cucurbitáceas, se mueve ineficientemente a larga distancia en $N$. benthamiana. Para averiguar los motivos, se clonó un aislado del ZYMV crecido en calabacines de la Horta de Vera en 2013 (AF127929.2) e insertó el factor de transcripción Roseal entre los cistrones virales NIb y CP (ZYMV-Ros1). Este clon viral no produce acumulación de antocianinas en el tejido infectado de cucurbitáceas, debido probablemente a la incompatibilidad del factor R2R3 MYB Rosea1 de A. majus con los factores de transcripción internos de la planta necesarios para desencadenar la biosíntesis de antocianinas. Al agroinfiltrar ZYMV-Ros1 en plantas de $N$. benthamiana se observó una eficiente multiplicación del virus en el tejido inoculado, con coloración rojiza debido a la acumulación de antocianinas, pero un ineficiente movimiento del virus a tejidos distales. Solo se observaron algunos focos rojos aislados en hojas apicales. Esto indica que en esta planta huésped hay mecanismos de defensa contra el ZYMV que impiden una infección sistémica. Una de las principales enzimas involucradas en la defensa de la planta son las RNasas de tipo III DCL, que procesan dsRNA procedentes del genoma viral, para producir siRNAs que desencadenan la ruta de silenciamiento postranscripcional. Gracias al Prof. Kriton Kalantidis (University of Crete) obtuvimos 6 líneas de plantas transgénicas de $N$. benthamiana silenciadas en DCL (DCL1i, DCL2i, DCL3i, DCL4i, DCL2/4i y DCL2/3/4i). Al inocular estas líneas con nuestro clon viral ZYMV-Ros1, se observó que todas las líneas silenciadas en DCL4 acumularon eficientemente antocianinas en tejidos distales; es decir, el movimiento sistémico del virus dejó de estar restringido. DCL4 está involucrada en la restricción del movimiento sistémico del ZYMV en plantas de $N$. benthamiana. Aunque los detalles de los mecanismos moleculares que median esta actividad son de momento desconocidos, se sabe que DCL4 restringe el paso del virus al floema y previene la salida del virus de los haces vasculares (Deleris et al., 2006).

El PVY se posiciona en el quinto lugar en importancia de los virus de plantas y es la mayor amenaza de cultivos de patata. Debido a su importancia biológica, clonamos PVY con el marcador Roseal que activa la biosíntesis de antocianinas y depositamos su secuencia completa en GenBank (KY780083). El clon viral presenta ineficiencia a la hora de transmitirse por agroinfiltración o directamente mediante el plásmido; sólo una de cada tres plantas de $N$. benthamiana presentó síntomas y coloración rojiza al cabo de más de 25 días postinoculación. Esta ineficiencia de transmisión mediante plásmido podría explicarse por la presencia de intrones crípticos que generan splicing en sitios indeseados del transcrito maduro (Marillonnet et al., 2005) o por promotores crípticos que inducen la síntesis de productos tóxicos en E. coli (Klenov and Hudak, 2021). En contraste, la inoculación mecánica de plantas de N. tabacum con 
tejido infectado fue muy eficiente. A los 6 días postinoculación las hojas apicales no inoculadas mostraron síntomas, y a los 12 días la acumulación de antocianinas fue máxima. Las antocianinas aparte de ser una buena herramienta biotecnológica para facilitar el análisis de las interacciones plantas-virus tienen gran interés farmacéutico, nutricional e incluso industrial por su gran actividad antioxidante. Se comprobó que el clon viral produce más antocianinas (concretamente cianidina-3-O-rutinósido) por gramo de tejido fresco que las que contienen frutas y verduras que son fuente rica de estos valiosos antioxidantes. A través de la inoculación mecánica de este virus recombinante y la producción de antocianinas que tiene lugar en el tejido infectado, el sistema PVY-Ros1 podría tener múltiples aplicaciones biotecnológicas. Se estudió la transmisión del virus por áfidos y se observó que a diferencia de una inoculación mecánica en la que la infección se inicia en células de la superficie de la hoja, la infección se inicia en el tejido vascular. Este clon viral también permitió mostrar visualmente el efecto antiviral que tienen las nanopartículas de plata en plantas, ya que se pudieron contabilizar los focos de infección gracias a la producción de antocianinas.

El género Potyvirus, uno de los grupos de virus de plantas más numeroso, está compuesto por virus de RNA de cadena positiva cuyo genoma contiene fundamentalmente un único marco abierto de lectura (ORF), a partir del cual se traduce una gran poliproteína que es procesada por tres proteasas virales, que liberan los diferentes productos génicos virales (Carrington et al., 1993) (Revers and García, 2015). Las proteasas P1 y HC-Pro, los dos productos amino terminales de la poliproteína viral, se autoescinden del precursor, mientras que el resto del procesamiento proteolítico depende de la actividad de la proteína de inclusión nuclear a (NIaPro) que reconoce un motivo de siete aminoácidos (-6/+1) alrededor de los diferentes sitios de procesamiento. La estricta especificidad de NIaPro por su sustrato y su eficiente actividad catalítica han convertido a esta proteasa en el objeto de muchas aplicaciones biotecnológicas (Cesaratto et al., 2016). Gracias a la especificidad de corte de NIaPro y la existencia de proteasas que reconocen otros sustratos derivadas de diferentes especies del género potyvirus se han podido desarrollar circuitos lógicos en E. coli (Férnandez-Rodríguez et al., 2016). El clon viral TEV-Ros1 expresa un cistrón extra donde se aloja el factor de transcripción Rosea1 de A. majus. El procesamiento proteolítico libera Rosea1 del resto de proteínas virales (Bedoya et al., 2012). Observamos que la fusión al extremo C-terminal de Roseal de distintas proteínas virales, como NIb o fragmentos de ella, impedía que el factor de transcripción fuese activo. Sin embargo, la acumulación de antocianinas podría restablecerse insertando sitios de reconocimiento de proteasas virales entre ambas partes y permitiendo la escisión del factor de 
transcripción mediante la coexpresión de proteasas específicas que reconocieran la secuencia proteolítica. Por lo tanto, al coexpresar en plantas a través de A. tumefaciens las diferentes construcciones que combinan el factor de transcripción Rosea1, el fragmento inhibidor de la ARN polimerasa ARN dependiente NIb y los sitios de reconocimiento de NIaPro del TEV y el TVMV con las correspondientes NIaPro, creamos circuitos genéticos basados en regulación postranscripcional que son capaces de realizar las operaciones lógicas básicas (puertas YES, OR y AND) en tejidos vegetales. Aunque la capacidad de procesamiento de ambas proteasas se demostró distinta, ya que el corte mediado por la NIaPro del TEV es más eficiente que el del TVMV, y la posición del fragmento inhibidor de NIb en N-terminal de Roseal disminuyó la eficiencia del corte, ambas problemas se solucionaron aumentando a tres los sitios de reconocimientos de NIaPro en cada una de las construcciones. 


\section{CONCLUSIONES}



- Hemos construido clones infecciosos de distintos potyvirus con Rosea1 de A. majus insertado en su genoma, lo que confiere al virus la capacidad de producir antocianinas en el tejido infectado. El factor de transcripción Rosea1 se insertó entre los cistrones NIb y CP, y flanqueado por sitios de procesamiento artificial NIaPro necesarios para ser liberado por el procesamiento proteolítico y activar la síntesis de antocianinas. Estos clones pueden tener muchas aplicaciones biotecnológicas.

- En plantas de N. benthamiana, ZYMV-Ros1 produce eficientemente la acumulación de antocianinas en el tejido agroinoculado pero solo unos pocos viriones son capaces de moverse por la planta y producir una infección sistémica, ya que observamos focos rojos muy dispersos en las hojas apicales. Sin embargo, este virus recombinante no induce la acumulación de antocianinas en el tejido infectado en especies de plantas de la familia de las cucurbitáceas como el melón o el calabacín, por incompatibilidad del factor de transcripción Roseal con el resto de factores de transcripción endógenos de la planta de la ruta de las antocianinas.

- En plantas de N. benthamiana silenciadas en DCL3 la multiplicación del ZYMV a nivel local en el tejido inoculado disminuye respecto al resto de mutantes DCL y plantas silvestres. Este efecto también se observa en la línea tripe silenciada DCL2/3/4. Por tanto, DCL3 parece necesario para la acumulación viral. Podría regular factores de la planta que favorezcan la multiplicación del virus.

- DCL4 está involucrado en la restricción del movimiento sistémico de ZYMV en $N$. benthamiana, ya que en plantas silenciadas para DCL4 la infección sistémica aumenta considerablemente. Este aumento es incluso mayor en las líneas con doble y triple silenciamiento DCL2/4 y DCL 2/3/4, lo que sugiere que DCL2 y DCL3 contribuyen a la actividad antiviral de DCL4.

- El virus recombinante PVY-Ros1 es muy inestable cuando se amplifica en E. coli un plásmido que lo contiene. Sin embargo, una vez inoculado en plantas es muy estable y se puede transmitir de planta a planta sin perder su gen marcador. 
- PVY-Ros1 puede ser una herramienta biotecnológica muy versátil, ya que en sus plantas huésped genera focos de infección fácilmente detectables a simple vista. Esta característica resultó muy útil para analizar la eficacia de productos fitosanitarios, como las nanopartículas de plata o para el seguimiento de la transmisión del virus a través de áfidos.

- Se demostró que PVY-Ros1 se puede utilizar para transformar plantas de N. tabacum en biofactorías, ya que se producen grandes cantidades de antocianinas ( $275 \mathrm{mg}$ por 100 $\mathrm{g}$ de tejido fresco) doce días después de la inoculación. En el sistema PVY-Ros1-N. tabacum se produce mayor acumulación de antocianinas, que en muchos frutos considerados ricos en ellas, como los arándanos o las moras.

- El factor de transcripción Roseal no activa la producción de antocianinas cuando se fusiona al extremo 5' de algunas proteínas del TEV. Cuando se fusiona a NIb y P1 del TEV, la aparición de síntomas es más tardía y no se activa la producción de antocianinas y, cuando se fusiona a HC-Pro la infección es asintomática.

- Las proteasas NIaPro de potyvirus, como las del TEV o TVMV, se pueden utilizar para recuperar la actividad como factor de transcripción de Roseal si la fusión de este con la proteína inhibitoria se separa por el sitio de proteólisis específico de cada proteasa.

- Con los componentes virales NIb, NIaPro y el factor de transcripción Rosea1 es posible el diseño de circuitos genéticos en plantas con una señal de salida visual. 


\section{BIBLIOGRAFÍA}



Alappat, B. and Alappat, J. (2020) Anthocyanin Pigments: Beyond Aesthetics. Molecules 25, 5500 .

Albert, N. W., Lewis, D. H., Zhang, H., Schwinn, K. E., Jameson, P. E., Davies, K. M. (2011). Members of an R2R3-MYB transcription factor family in Petunia are developmentally and environmentally regulated to control complex floral and vegetative pigmentation patterning. Plant J. 65, 771-784

Antunes, M.S., Morey, K.J., Smith, J.J., Albrecht, K.D., Bowen, T.A., Zdunek, J.K., Troupe, J.F., et al. (2011). Programmable ligand detection system in plants through a synthetic signal transduction pathway. PLoS One 6, e16292.

Arazi, T., Slutsky, S. G., Shiboleth, Y.M., Wang, Y., Rubinstein, M., Barak, S., Yang, J. and Gal-On, A. (2001). Engineering zucchini yellow mosaic potyvirus as a non-pathogenic vector for expression of heterologous proteins in cucurbits. J. Biotechnol. 87(1), 67-82.

Ausländer, S., Ausländer, D., Muller, M., Wieland, M. and Fussenegger, M. (2012). Programmable single-cell mammalian biocomputers. Nature 487, 123-127.

Avesani, L., Marconi, G., Morandini, F., Albertini, E., Bruschetta, M., Bortesi, L., Pezzotti, M. and Porceddu, A. (2007). Stability of Potato virus X expression vectors is related to insert size: implications for replication models and risk assessment. Transgenic Res. 16(5), 587- 597.

Azeredo, H.M.C. (2009). Betalains: properties, sources, applications, and stability - a review. International Journal of Food Science \& Technology 44, 2365-2376.

Bartel, D. P. (2004). MicroRNAs: genomics, biogenesis, mechanism, and function. Cell 116, 281-297.

Baulcombe, D.C., Chapman, S. and Santa Cruz, S. (1995). Jellyfish green fluorescent protein as a reporter for virus infections. Plant J. 7(6), 1045-1053.

Baulcombe, D. (2004). RNA silencing in plants. Nature 431, 356-363. 
Baumberger, N., Baulcombe, D. C. (2005). Arabidopsis ARGONATUTE1 is an RNA Slicer that selectively recruits microRNAs and short interfering RNAs. Proc. Natl. Acad. Sci. U.S.A. $102,11928-11933$.

Beauchemin, C., Bougie, V. and Laliberté, J. F. (2005). Simultaneous production of two foreign proteins from a potyvirus-based vector. Virus Res. 112(1-2), 1-8.

Bedoya, L.C. and Daròs, J.A. (2010a). Stability of Tobacco etch virus infectious clones in plasmid vectors. Virus Res. 149(2), 234-240.

Bedoya, L., Martínez, F., Rubio, L. and Daròs, J.A. (2010b). Simultaneous equimolar expression of multiple proteins in plants from a disarmed potyvirus vector. J Biotechnol. 150(2), $268-275$.

Bedoya, L.C., Martínez, F., Orzáez, D. and Daròs, J.A. (2012). Visual tracking of plant virus infection and movement using a reporter MYB transcription factor that activates anthocyanin biosynthesis. Plant Physiol. 158(3), 1130-1138.

Bologna, N.G. and Voinnet, O. (2014). The diversity, biogenesis, and activities of endogenous silencing small RNAs in Arabidopsis. Annual Review of Plant Biology 65, 473-503.

Brodersen, P., Sakvarelidze-Achard, L., Bruun-Rasmussen, M., Dunoyer, P., Yamamoto, Y.Y., Sieburth, L. and Voinnet, O. (2008). Widespread Translational Inhibition by Plant miRNAs and siRNAs. Science 320, 1185-1190.

Butelli, E., Titta, L., Giorgio, M., Mock, H.P., Matros, A., Peterek, S., Schijlen, E.G. et al. (2008). Enrichment of tomato fruit with health-promoting anthocyanins by expression of select transcription factors. Nat Biotechnol. 26(11), 1301-1308.

Cameron, D.E., Bashor, C.J. and Collins J.J. (2014). A brief history of synthetic biology. Nat Rev Microbiol. 12, 381-390. 
Caplan, J.L., Mamillapalli, P., Burch-Smith, T.M., Czymmek, K. and Dinesh-Kumar, S.P. (2008). Chloroplastic protein NRIP1 mediates innate immune receptor recognition of a viral effector. Cell 132(3), 449-462.

Carlsson, M.L.R., Kanagarajan, S., Bülow, L. and Zhu, L. (2020). Plant based production of myoglobin-a novel source of the muscle heme-protein. Sci. Rep. 10, 920.

Carrington, J.C., Cary, S. M., Parks, T.D. and Dougherty, W. G. (1989a). A second proteinase encoded by a plant potyvirus genome. EMBO J. 8(2), 365-370.

Carrington, J.C., Freed, D.D. and Sanders, T.C. (1989b). Autocatalytic processing of the potyvirus helper component proteinase in Escherichia coli and in vitro. J. Virol. 63(10), 44594463.

Carrington, J.C., Freed, D.D. and Oh, C.S. (1990). Expression of potyviral polyproteins in transgenic plants reveals three proteolytic activities required for complete processing. $E M B O$ J. 9(5), 1347-1353.

Carrington, J.C., Haldeman, R., Dolja, V.V. and Restrepo-Hartwig, M.A. (1993). Internal cleavage and trans-proteolytic activities of the VPg-proteinase (NIa) of tobacco etch potyvirus in vivo. $J$ Virol. 67(12), 6995-7000.

Carthew, R.W. and Sontheimer, E.J. (2009). Origins and Mechanisms of miRNAs and siRNAs. Cell 136, 642-655.

Cesaratto, F., Burrone, O.R., Petris, G. (2016). Tobacco Etch Virus protease: A shortcut across biotechnologies. J. Biotechnol. 231, 239-249.

Chan, S.W., Zilberman, Z., Xie, L., Johansen, L.K., Carrington, J.C., Jacobsen, S.E. (2004). RNA silencing genes control de novo DNA methylation. Science 303, 1336.

Chapman, S., Kavanagh, T. and Baulcombe, D. (1992). Potato virus X as a vector for gene expression in plants. Plant J. 2(4), 549-557. 
Chapman, E., Carrington, J. C. (2007). Specialization and evolution of endogenous small RNA pathways. Nat. Rev. Gen. 8, 884-896.

Chen, H. and Lin, Y. (2013). Promise and issues of genetically modified crops. Curr Opin Plant Biol. 16(2), 255-260.

Chilton, M.D., Drummond, M.H., Merio, D.J., Sciaky, D., Montoya, A.L., Gordon, M.P. and Nester, E.W. (1977). Stable incorporation of plasmid DNA into higher plant cells: the molecular basis of crown gall tumorigenesis. Cell 11(2), 263-271.

Chung, B.Y.W., Miller, W.A., Atkins, J.F. and Firth, A.E. (2008). An overlapping essential gene in the Potyviridae. Proc Natl Acad Sci U.S.A. 105(15), 5897-5902.

Cogoni, C. and Macino, G. (2000). Post-transcriptional gene silencing across kingdoms. Current Opinion in Genetics and Development 10, 638-643.

Day, R.N. and Davidson, M.W. (2009). The fluorescent protein palette: tools for cellular imaging. Chem Soc Rev. 38(10), 2887-2921.

Deleris, A., Gallego-Bartolome, J., Bao, J., Kasschau, K.D., Carrington, J.C. and Voinnet, O. (2006). Hierarchical action and inhibition of plant Dicer-like proteins in antiviral defense. Science 313, 68-71.

Dietrich, C. and Maiss, E. (2003). Fluorescent labelling reveals spatial separation of potyvirus populations in mixed infected Nicotiana benthamiana plants. J Gen Virol. 84, 2871- 2876.

Ding, S.W. and Voinnet, O. (2007). Antiviral immunity directed by small RNAs. Cell 130, 413426.

Dolja, V.V., McBride, H.J. and Carrington, J.C. (1992). Tagging of plant potyvirus replication and movement by insertion of $\beta$-glucuronidase into the viral polyprotein. Proc Natl Acad Sci U.S.A. 89(21), 10208-10212. 
Dolja, V.V., Hong, J., Keller, K.E., Martin, R.R. and Peremyslov, V.V. (1997). Suppression of Potyvirus Infection by Coexpressed Closterovirus Protein. Virology. 234(2), 243-252.

Dunoyer, P. and Voinnet, O. (2005). The complex interplay between plant viruses and host RNA-silencing pathways. Curr. Opin. Plant Biol. 8, 415-423.

Elowitz, M. B. and Leibler, S. (2000). A synthetic oscillatory network of transcriptional regulators. Nature 403, 335-8.

Faye, L. and Gomord, V. (2010). Success stories in molecular farming-a brief overview. Plant Biotechnol. J. 8(5), 525-528.

Ferber, D. (2004). Synthetic Biology: Microbes Made to Order. Science 303, 158-161.

Fernández-Fernández, M.R., Mouriño, M., Rivera, J., Rodríguez, F., Plana-Durán, J. and García, J.A. (2001). Protection of rabbits against rabbit hemorrhagic disease virus by immunization with the VP60 protein expressed in plants with a potyvirus-based vector. Virology 280(2), 283-291.

Férnandez-Rodríguez, J., Voigt, C.A. (2016). Post-translational control of genetic circuits using Potyvirus proteases. Nucleic Acids Research 44(13), 6493-6502.

Fire, A. (1999) RNA-triggered gene silencing. Trends in Genetics 15, 358-363.

François, P. and Hakim, V. (2003). Design of genetic networks with specified functions by evolution in silico. PNAS, 101, 580-585.

Fredens, J., Wang K., de la Torre, D., Funke, L.F.H., Robertson, W.E., Christova, Y., Chia, T., et al. (2019). Total synthesis of Escherichia coli with a recoded genome. Nature 569 (7757), 514-518.

Gardner, T.S., Cantor, C.R. and Collins, J. (2000) Construction of a genetic toggle switch in Escherichia coli. Nature 403, 339-342. 
Geisler, K., Hughes, R.K., Sainsbury, F., Lomonossoff, G. P., Rejzek, M., Fairhurst, S., Olsen, C.E., Motawia, M.S., Melton, R.E., Hemmings, A.M., Bak, S. and Osbourn, A. (2013). Biochemical analysis of a multifunctional cytochrome P450 (CYP51) enzyme required for synthesis of antimicrobial triterpenes in plants. Proc Natl Acad Sci U.S.A. 110(35), 3360-3367.

German-Retana, S., Candresse, T., Alias, E., Delbos, R.P. and Le Gall, O. (2000). Effects of green fluorescent protein or beta-glucuronidase tagging on the accumulation and pathogenicity of a resistance-breaking Lettuce mosaic virus isolate in susceptible and resistant lettuce cultivars. Mol. Plant Microbe Interact. 13(3), 316-324.

Gibson, D.G., Young, L., Chuang, R.Y., Venter, J.C., Hutchison, C.A., $3^{\text {rd }}$ and Smith, H.O. (2009). Enzymatic assembly of DNA molecules up to several hundred kilobases. Nat. Methods 6(5), 343-345.

Gils, M., Kandzia, R., Marillonnet, S., Klimyuk, V. and Gleba, Y. (2005). High-yield production of authentic human growth hormone using a plant virus-based expression system. Plant Biotechnol J. 3(6), 613-620.

Giritch, A., Marillonnet, S., Engler, C., van Eldik, G., Botterman, J., Klimyuk, V. and Gleba, Y. (2006). Rapid high-yield expression of full-size IgG antibodies in plants coinfected with noncompeting viral vectors. Proc. Natl. Acad. Sci. U.S.A. 103(40), 14701-14706.

Gleba, Y., Marillonnet, S. and Klimyuk, V. (2004). Engineering viral expression vectors for plants: the 'full virus' and the 'deconstructed virus' strategies. Curr. Opin. Plant Biol. 7(2), 182188.

Gleba, Y., Klimyuk, V. and Marillonnet, S. (2005). Magnifection-a new platform for expressing recombinant vaccines in plants. Vaccine 18(23), 2042-2048.

Gleba, Y., Klimyuk, V. and Marillonnet, S. (2007). Viral vectors for the expression of proteins in plants. Curr. Opin. Biotechnol. 18(2), 134-141.

Gleba, Y., Tuse, D. and Giritch, A. (2014). Plant viral vectors for delivery by Agrobacterium. Curr. Top Microbiol. Immunol. 375, 155-192. 
Grimsley, N., Hohn, B., Hohn, T. and Walden, R. (1986). "Agroinfection," an alternative route for viral infection of plants by using the Ti plasmid. Proc Natl Acad Sci U.S.A. 83(10), 32823286.

Haasnoot, J., Westerhout, E. M. and Berkhout, B. (2007). RNA interference against viruses: strike and counterstrike. Nat. Biotechnol. 25, 1435-1443.

Hamilton, A.J. and Baulcombe, D.C. (1999). A species of small antisense RNA in posttranscriptional gene silencing in plants. Science 286, 950-952.

Hammond, S. M., Bernstein, E., Beach, D. and Hannon, G. J. (2000). An RNA-directed nuclease mediates post-transcriptional gene silencing in Drosophila cells. Nature 404, 293-296.

Hefferon, K. L. (2012). Plant virus expression vectors set the stage as production platforms for biopharmaceutical proteins. Virology 433, 1-6.

Heim, R., Prasher, D.C. and Tsien, R.Y. (1994). Wavelength mutations and posttranslational autoxidation of green fluorescent protein. Proc. Natl. Acad. Sci. U.S.A. 91, 12501-12504.

Heim, R., Cubitt, A.B. and Tsien, R.Y. (1995). Improved green fluorescence. Nature 373, 663 664.

Henderson, I.R., Zhang, X., Lu, C., Johnson, L., Meyers, B.C., Green, P. and Jacobsen, S. E. (2006). Dissecting Arabidopsis thaliana DICER function in small RNA processing, gene silencing and DNA methylation patterning. Nat. Genet. 38, 721-725.

Herrera-Estrella, L., Block, M.D., Messens, E., Hernalsteens, J.P., Montagu, M.V. and Schell, J. (1983). Chimeric genes as dominant selectable markers in plant cells. EMBO J. 2(6), 987995.

Hichri I, Barrieu F, Bogs J, Kappel C, Delrot S, Lauvergeat V. (2011). Recent advances in the transcriptional regulation of the flavonoid biosynthetic pathway. $J$ Exp Bot. 62(8), 2465-2483. 
Holton, T. A., and Cornish, E. C. (1995). Genetics and Biochemistry of Anthocyanin Biosynthesis. Plant Cell 7(7), 1071-1083.

Hsieh, L.C., Lin, S.I., Shih, A.C.C., Chen, J.W., Lin, W.Y., Tseng, C.Y., et al. (2009). Uncovering small RNA-mediated responses to phosphate deficiency in Arabidopsis by deep sequencing. Plant Physiol. 151, 2120-2132.

Huang, Z., Santi, L., LePore, K., Kilbourne, J., Arntzen, C.J. and Mason, H.S. (2006). Rapid, high level production of hepatitis B core antigen in plant leaf and its immunogenicity in mice. Vaccine 24(14), 2506-2513.

Hutchison, C.A., Chuang, R.Y., Noskov, V.N., Assad-Garcia, N., Deerinck, T.J., Ellisman, M.H., Gill, J.et al. (2016) "Design and synthesis of a minimal bacterial genome". Science. 351.

Ivanov, K.I., Eskelin, K., Lohmus, A. and Makinen, K. (2014). Molecular and cellular mechanisms underlying potyvirus infection. J Gen Virol. 95(7), 1415-1429.

Jefferson, R.A. (1987). Assaying Chimeric Genes in Plants: The GUS Gene Fusion System. Plant Molecular Biology Reporter 5(4), 387-405.

Jones-Rhoades, M.W. and Bartel, D.P. (2004). Computational identification of plant microRNAs and their targets, including a stress-induced miRNA. Mol Cell. 14, 787-799.

Jones-Rhoades, M.W., Bartel, D.P. and Bartel, B. (2006). MicroRNAs and their regulatory roles in plants. Annu Rev Plant Biol. 57, 19-53.

Kalantidis, K., Schumacher, H.T., Alexiadis, T. and Helm, J. M. (2008). RNA silencing movement in plants. Biol. Cell 100, 13-26.

Katsarou, K., Mavrothalassiti, E., Dermauw, W., Van Leeuwen, T., Kalantidis, K. (2016). Combined activity of DCL2 and DCL3 is crucial in the defense against Potato spindle tuber viroid. PLoS Pathog. 12.

Khan, Z.A., Hiriyanna, F., Chavez, F. and Fraenkel-Conrat, H. (1986). RNA-directed RNA 
polymerases from healthy and from virus-infected cucumber. Proc. Natl. Acad. Sci. U.S.A. 83, $2382-2386$

Klenov, A. and Hudak, K.A. (2021) Facile method of curing toxicity in large viral genomes by high-throughput identification and removal of cryptic promoters. J. Virol. Methods, 287.

Kumagai, M.H., Donson, J., della-Cioppa, G., Harvey, D., Hanley, K. and Grill, LK. (1995). Cytoplasmic inhibition of carotenoid biosynthesis with virus-derived RNA. Proc. Natl. Acad. Sci U.S.A. 92(5), 1679-1683.

Kurihara, Y. and Watanabe, Y. (2004). Arabidopsis micro-RNA biogenesis through Dicer-like 1 protein functions. Proc. Natl. Acad. Sci. U.S.A. 101, 12753-12758.

Leduc, S. La biologie synthétique. A. Poinat. Paris. 1912.

Li, X.H. and Carrington, J.C. (1995). Complementation of tobacco etch potyvirus mutants by active RNA polymerase expressed in transgenic cells. Proc. Natl. Acad. Sci. U.S.A. 92(2), $457-$ 461 .

Li, H.W. and Ding, S.W. (2005). Antiviral silencing in animals. FEBS Lett. 579(26), 59655973.

Lindbo, J.A. (2007). TRBO: a high-efficiency tobacco mosaic virus RNA-based overexpression vector. Plant Physiol. 145(4), 1232-1240.

Ma J.K., Drossard J., Lewis D., Altmann F., Boyle J., Christou P., Cole T., Dale P., van Dolleweerd C.J., Isitt V., et al. (2015). Regulatory approval and a first-in-human phase I clinical trial of a monoclonal antibody produced in transgenic tobacco plants. Plant Biotechnol. J. 13, $1106-1120$.

Majer, E., Salvador, Z., Zwart, M.P., Elena, S.F. and Daròs, J.A. (2014). Relocation of the NIb gene in the tobacco etch potyvirus genome. J. Virol. 88(8), 4589-90. 
Majer, E., Navarro, J.A. and Daròs, J.A. (2015). A potyvirus vector efficiently targets recombinant proteins to chloroplasts, mitochondria and nuclei in plant cells when expressed at the amino terminus of the polyprotein. Biotechnol. J. 10(11), 1792-802.

Majer, E., Llorente, B., Rodríguez-Concepción, M. and Daròs, J.A. (2017) Rewiring carotenoid biosynthesis in plants using a viral vector. Sci. Rep. 7, 41645.

Marillonnet, S., Giritch, A., Gils, M., Kandzia, R., Klimyuk, V. and Gleba, Y. (2004). In planta engineering of viral RNA replicons: efficient assembly by recombination of DNA modules delivered by Agrobacterium. Proc. Natl. Acad. Sci. U.S.A. 101(18), 6852-6857.

Marillonnet, S., Thoeringer, C., Kandzia, R., Klimyuk, V., Gleba, Y. (2005). Systemic Agrobacterium tumefaciens-mediated transfection of viral replicons for efficient transient expression in plants. Nat. Biotechnol. 23, 718-723.

Matz, M.V., Lukyanov, K.A. and Lukyanov, S.A. (2002). Family of the green fluorescent protein: journey to the end of the rainbow. Bioessays 24(10), 953-959.

Matzke, M.A and Matzke, A. J. M. (2004) Planting the Seeds of a New Paradigm. PLoS Biol. 2(5), e133.

Mingot, A., Valli, A., Rodamilans, B., San León, D., Baulcombe, D.C., García, J.A. and LópezMoya, J.J. (2016). The P1N-PISPO trans-frame gene of sweet potato feathery mottle potyvirus is produced during virus infection and functions as an RNA silencing suppressor. J. Virol.90(7), 3543-3557.

Moissard, G. and Voinnet, O. (2006). RNA silencing of host transcripts by Cauliflower mosaic virus requires coordinated action of the four Arabidopsis Dicer-like proteins. Proc. Natl. Acad. Sci. U.S.A 103, 19593-19598.

Molina-Hidalgo, F. J., Vazquez-Vilar, M., D’Andrea, L., Demurtas, O. C., Fraser, P., Giuliano, G., Bock, R., et al. (2020). Engineering Metabolism in Nicotiana Species: A Promising Future. Trends Biotechnol. 20, 30307-3. 
Mozes-Koch, R., Gover, O., Tanne, E., Peretz, Y., Maori, E., Chernin, L. and Sela, I. (2012). Expression of an entire bacterial operon in plants. Plant Physiol. 158(4), 1883-1892.

Napoli, C., Lemieux, C. and Jorgensen, R. (1990). Introduction of a chimeric chalcone synthase gene into Petunia results in reversible co-suppression of homologous genes in trans. Plant Cell 2, 279-289.

Nelson, R.S. and Citovsky, V. (2005). Plant viruses. Invaders of cells and pirates of cellular pathways. Plant Physiol. 138(4), 1809-1814.

Oparka, K., Roberts, G., Santa Cruz, S., Boevink, P., Prior, D. and Smallcombe, A. (1997). Using GFP to study virus invasrion and spread in plant tissues. Nature 388, 401-402.

Ormo, M., Cubitt, A.B., Kallio, K., Gross, L.A., Tsien, R.Y. and Remington, S.J. (1996). Crystal structure of the Aequorea victoria green fluorescent protein. Science 273, 1392-1395.

Park, W., Li, J., Song, R., Messing, J. and Chen, X. (2002) CARPEL FACTORY, a Dicer homolog, and HEN1, a novel protein, act in microRNA metabolism in Arabidopsis thaliana. Curr. Biol. 12, 1484-1495.

Pasin, F., Menzel, W. and Daròs, J.A. (2019). Harnessed viruses in the age of metagenomic and synthetic biology: an update on infectious clone assembly and biotechnologies of plant viruses. Plant Biotechnol. J. 17(6), 1010-1026.

Passeri, V., Koes, R., and Quattrocchio, F.M. (2016). New challenges for the design of high value plant products: stabilization of anthocyanins in plant vacuoles. Front. Plant Sci. 7, 153.

Phoolcharoen, W., Bhoo, S.H., Lai, H., Ma, J., Arntzen, C.J., Chen, Q. and Mason H.S. (2011). Expression of an immunogenic Ebola immune complex in Nicotiana benthamiana. Plant Biotechnol. J. 9, 807-816.

Piazza, P., Procissi, A., Jenkins, G. I., Tonelli, C. (2002). Members of the c1/pl1 regulatory gene family mediate the response of maize aleurone and mesocotyl to different light qualities and cytokinins. Plant Physiol. 128, 1077-1086. 
Polturak, G., D. Breitel, N., Grossman, A., Sarrion-Perdigones, E., Weithorn, M., Pliner, D., Orzaez, D. et al. (2016). Elucidation of the first committed step in betalain biosynthesis enables the heterologous engineering of betalain pigments in plants. New Phytologist 210, 269-283.

Prasher, D.C., Eckenrode, V.K., Ward, W.W., Prendergast, F.G. and Cormier, M.J. (1992). Primary structure of the Aequorea victoria green-fluorescent protein. Gene 111, 229-233.

Rattanapisit, K., Chao, Z., Siriwattananon, K., Huang, Z. and Phoolcharoen, W. (2019). PlantProduced Anti-Enterovirus 71 (EV71) Monoclonal Antibody Efficiently Protects Mice Against EV71 Infection. Plants (Basel) 8(12), 560.

Restrepo, M.A., Freed, D.D. and Carrington, J.C. (1990). Nuclear transport of plant potyviral proteins. Plant Cell 2(10), 987-998.

Revers, F. and García, J.A. (2015). Molecular biology of potyviruses. Adv. Virus Res. 92, 10199.

Riedel, D., Lesemann, D.E. and Maiss, E. (1998). Ultrastructural localization of nonstructural and coat proteins of 19 potyviruses using antisera to bacterially expressed proteins of plum pox potyvirus. Arch. Virol. 143(11), 2133-2158.

Robertson, D. (2004). VIGS vectors for gene silencing: many targets, many tools. Annu. Rev. Plant Biol. 55, 495-519.

Ruiz-Ramón, F., Sempere, R.N., Méndez-López, E., Sánchez-Pina, M.A. and Aranda, M.A. (2019). Second generation of pepino virus vectors: improved stability in tomato and a wide range of reporter genes. Plant Methods 15, 58.

Sainsbury, F., Thuenemann, E.C., Lomonossoff, G.P. (2009). pEAQ: versatile expression vectors for easy and quick transient expression of heterologous proteins in plants. Plant Biotechnol. J. 7, 682-693. 
Sainsbury, F., Cañizares, M.C., Lomonossoff, G.P. (2010). Cowpea mosaic virus: the plant virus-based biotechnology workhorse. Annu. Rev. Phytopathol. 48, 437-455.

Sainsbury, F., Saxena, P., Geisler, K., Osbourn, A. and Lomonossoff, G.P. (2012). Using a virus derived system to manipulate plant natural product biosynthetic pathways. Methods Enzymol. 517, 185-202.

Sainsbury, F. and Lomonossoff, G.P. (2014). Transient expressions of synthetic biology in plants. Curr. Opin. Plant. Biol. 19, 1-7.

Santi, L., Giritch, A., Roy, C.J., Marillonnet, S., Klimyuk, V., Gleba Y., Webb, R., et al. (2006). Protection conferred by recombinant Yersinia pestis antigens produced by a rapid and highly scalable plant expression system. Proc. Natl. Acad. Sci. U.S.A. 103(4), 861-866.

Savageau, M. A. (2001). Design principles for elementary gene circuits: Elements, methods, and examples. Chaos (Woodbury, N.Y.), 11 (1), 142-159.

Schillber, S. and Finnern, R. (2021). Plant molecular farming for the production of valuable proteins-Critical evaluation of achievements and future challenges. J. Plant Physiol. 258-259, 153359.

Schwinn, K., Venail, J., Shang, Y., Mackay, S., Alm, V., Butelli, E., Oyama, R. et al. (2006). A small family of MYB-regulatory genes controls floral pigmentation intensity and patterning in the genus Antirrhinum. Plant Cell 18(4), 831-851.

Shanmugaraj, B., Bulaon, C. J. and Phoolcharoen, W. (2020). Plant molecular farming: A Viable Platform for Recombinant Biopharmaceutical Production. Plants 9 (7), 842.

Shi, X., Cordero, T., Garrigues, S., Marcos, J.F., Dàros, J.A. and Coca, M. (2019) Plant Efficient production of antifungal proteins in plants using a new transient expression vector derived from tobacco mosaic virus. Biotechnology Journal 17, 1069-1080.

Shimomura, O. (1979) Structure of the chromophore of Aequorea green fluorescent protein. FEBS Lett. 104, 220-222. 
Shivprasad, S., Pogue, G.P., Lewandowski, D.J., Hidalgo, J., Donson, J., Grill, L.K. and Dawson, W.O. (1999) Heterologous sequences greatly affect foreign gene expression in tobacco mosaic virus-based vectors. Virology 255, 312-323.

Sismour, A. M. and Benner, S. A. (2005). The use of thymidine analogs to improve the replication of an extra DNA base pair: a synthetic biological system. Nucleic Acids Res. 33(17), $5640-6$.

Siuti, P., Yazbek, J. and Lu, T.K. (2013). Synthetic circuits integrating logic and memory in living cells. Nat Biotechnol. 31, 448-452.

Smith, H. O., Hutchison, C. A $3^{\text {rd }}$, Pfannkoch, C. and Venter, J. C. (2003). Generating a synthetic genome by whole genome assembly: $\phi X 174$ bacteriophage from synthetic oligonucleotides. PNAS 100, 15440-15445

Stewart, C.N. (Jr.). (2001). The utility of green fluorescent protein in transgenic plants. Plant Cell Rep. 20, 376-382.

Sunkar, R. and Zhu, J.K. (2004). Novel and stress-regulated microRNAs and other small RNAs from Arabidopsis. Plant Cell. 16, 2001-2019.

Tanaka, Y., Sasaki, N. and Ohmiya, A. (2008). Biosynthesis of plant pigments: anthocyanins, betalains and carotenoids. Plant J. 54(4), 733-749.

Tenllado, F. and Díaz-Ruiz, J.R. (2001). Double-stranded RNA-mediated interference with plant virus infection. J. Virol. 75, 12288-12297.

Tenllado, F., Martínez-García, B., Vargas, M. and Díaz-Ruiz, J. R. (2003). Crude extracts of bacterially expressed dsRNA can be used to protect plants against virus infections. $B M C$ Biotechnol. 3.

Thole, V., Worland, B., Snape, J.W., Vain, P. (2007). The pCLEAN dual binary vector system for Agrobacterium-mediated plant transformation. Plant Physiol. 145, 1211-1219. 
Tian, L., Pang, Y. and Dixon, R.A. (2007). Biosynthesis and genetic engineering of proanthocyanidins and (iso)flavonoids. Phytochem. Rev. 1-21.

Tian, J., Pei, H., Zhang, S., Chen, J., Chen, W., Yang, R., Meng, Y. et al. (2014). TRV-GFP: a modified Tobacco rattle virus vector for efficient and visualizable analysis of gene function. Journal of experimental botany 65(1), 311-22.

Tilsner, J. and Oparka, K.J. (2010). Tracking the green invaders: advances in imaging virus infection in plants. Biochem J. 430(1), 21-37.

Tsien, R.Y. (1998).The Green Fluorescent Protein. Annu. Rev. Biochem. 67, 509-544.

Tuse D., Ku N., Bendandi M., Becerra C., Collins R., Jr., Langford N., Sancho S.I., Lopez-Diaz de Cerio A., Pastor F., Kandzia R., et al. (2015). Clinical Safety and Immunogenicity of TumorTargeted, Plant-Made Id-KLH Conjugate Vaccines for Follicular Lymphoma. Biomed. Res. Int. 2015,648143 .

Urcuqui-Inchima, S., Haenni, A.L. and Bernardi, F. (2001). Potyvirus proteins: a wealth of functions. Virus Res. 74(1-2), 157-175.

Van Der Krol, A.R., Mur, L.A., Beld, M., Mol, J.N. and Stuitje, A.R. (1990). Flavonoid genes in Petunia: addition of a limited number of gene copies may lead to a suppression of gene expression. Plant Cell 2, 291-299.

Vance, V. and Vaucheret, H. (2001). RNA silencing in plants-defense and counter defense. Science 292, 2277-2280.

Vaucheret, H., Béclin, C. and Fagard, M. (2001). Post-transcriptional gene silencing in plants. Journal of Cell Science 114, 3083-3091. 
Venetz, J.E, Del Medico, L., Wölfle, A., Schächle, P., Bucher, Y., Appert, D., Tschan, F., et al. (2019). Chemical synthesis rewriting of a bacterial genome to achieve design flexibility and biological functionality. Proc. Natl. Acad. Sci. U.S.A. 116(16), 8070-8079.

Verchot, J., Koonin, E.V. and Carrington, J.C. (1991). The 35-kDa protein from the N-terminus of the potyviral polyprotein functions as a third virus-encoded proteinase. Virology 185(2), 527535.

Verdel, A., Jia, S., Gerber, S., Sugiyama, T., Gygy, S., Grewal, S.I. and Moazed, D. (2004). RNAi-mediated targeting of heterochromatin by the RITS complex. Science 303, 672-676.

Verpoorte, R. and Memelink, J. (2002). Engineering secondary metabolite production in plants. Curr. Opin. Biotechnol. 13, 181-187.

Vitale, A. and Denecke, J. (1999). The endoplasmic reticulum-gateway of the secretory pathway. Plant Cell 11(4), 615-628.

Voinnet, O., Lederer, C. and Baulcombe, D.C. (2000). A viral movement protein prevents spread of the gene silencing signal in Nicotiana benthamiana. Cell 103, 157-167.

Voinnet, O. (2005). Induction and suppression of RNA silencing: insights from viral infections. Nat. Rev. Genet. 6, 206-220.

Voinnet, O. (2008). Post- transcriptional RNA silencing in plant-microbe interactions: a touch of robustness and versatility. Current Opinion in Plant Biology 11, 464-470.

Wang, L. (2001). Expanding the genetic code of E. coli, Science 292, 498-500.

Wang, M., Gao, S., Zeng, W., Yang, Y., Ma, J., and Wang, Y. (2020). Plant Virology Delivers Diverse Toolsets for Biotechnology. Viruses 12, 1338.

Wassenegger, M. (2005). The role of the RNAi machinery in heterochromatin formation. Cell $122,13-16$. 
Wassenegger, M. and Krczal, G. (2006). Nomenclature and functions of RNA-directed RNA polymerases. Trends Plant Sci. 11, 142-151.

Wassenegger, M., Heimes, S., Riedel, L. and Sanger, H.L. (1994). RNA-directed de novo methylation of genomic sequences in plants. Cell 76, 567-576.

Waterhouse, P.M. and Helliwell, C.A. (2003). Exploring plant genomes by RNA-induced gene silencing. Nat. Rev. Genet. 4, 29-38.

Webster, D.E., Wang, L., Mulcair, M., Ma, C., Santi, L., Mason, H.S., Wesselingh, S.L., et al. (2009). Production and characterization of an orally immunogenic Plasmodium antigen in plants using a virus-based expression system. Plant Biotechnol. J. 7(9), 846- 855.

Wei, T., Zhang, C., Hong, J., Xiong, R., Kasschau, K.D., Zhou, X., Carrington, J.C., et al. (2010a). Formation of complexes at plasmodesmata for potyvirus intercellular movement is mediated by the viral protein P3N-PIPO. PLoS Pathog. 6(6), e1000962.

Wei, T., Huang, T.S., McNeil, J., Laliberté, J.F., Hong, J., Nelson, R.S. and Wang A. (2010b). Sequential recruitment of the endoplasmic reticulum and chloroplasts for plant potyvirus replication. J Virol. 84(2), 799-809.

Weiss, R., Basu, S., Hooshangu, S., Kalmbach, A., Karig, D., Mehreja, R. and Netravali, I. (2003). Genetic circuit building blocks for cellular computation, communications, and signal processing. Natural computing 2, 47-84.

Willson, C., Perrin, D., Cohn, M. and Monod, J. (1964). Non-inducible mutants of the regulator gene in the "lactose" system of Escherichia coli. J. Mol. Biol. 8, 582-592.

Xie, Z., Fan, B., Chan, C. and Chan, Z. (2001). An important role of an inducible RNAdependent RNA polymerase in plant antiviral defense. Proc. Natl. Acad. Sci. U.S.A 98, 65166521.

Xie, Z., Johansen, L.K., Gustafson, A. M., Kasschau, K.D., Lellis, A.D., Zilberman, D., Jacobsen, S.E., et al. (2004). Genetic and functional diversification of small RNA pathways in plants. PLoS Biol. 2, 1-11. 
Xu, J., Dolan, M.C., Medrano, G., Cramer, C.L. and Weathers, P.J. (2012). Green factory: plants as bioproduction platforms for recombinant proteins. Biotechnol. Adv. 30(5), 1171-1184.

Ye, X., Al-Babili, S., Klöti, A., Zhang, J., Lucca, P., Beyer P. and Potrykus I. (2000). Engineering the provitamin A ( $\beta$-carotene) biosynthetic pathway into (carotenoid-free) rice endosperm. Science 287, 303-305.

Yu, D., Fan, B., Macfarlane, S. and Chen, Z. (2003). Analysis of the involvement of an inducible Arabidopsis RNA-dependent RNA polymerase in antiviral defense. Mol. PlantMicrobe Interact. 16, 206- 216.

Zabel, P., Weenen-Swaans, H. and Van Kammen, A. (1974). In vitro replication of Cowpea mosaic virus RNA. I. Isolation and properties of the membrane-bound replicase. J. Virol. 14, 1049-1055.

Zambryski, P., Joos, H., Genetello, C., Leemans, J., Montagu, M.V. and Schell, J. (1983). Ti plasmid vector for the introduction of DNA into plant cells without alteration of their normal regeneration capacity. EMBO J. 2(12), 2143-2150.

Zhang, H., Wang, L., Hunter, D., Voogd, C., Joyce, N. and Davies, K. (2013). A Narcissus mosaic viral vector system for protein expression and flavonoid production. Plant Methods $9(1), 28$.

Zhang, Y., Butelli, E., and Martin, C. (2014). Engineering anthocyanin biosynthesis in plants. Curr. Opin. Plant Biol. 19, 81-90. 
AGRADECIMIENTOS 

Para empezar quiero agradecer al director de esta tesis doctoral, Dr. José Antonio Daròs Arnau, por enseñarme todo lo que sé de biología molecular, por su dedicación y paciencia para enseñarnos siempre las claves técnicas para que todo saliera bien y por su confianza en esta tesis y sobretodo, en mí desde el primer día que pisé el 1.05. Y al tutor, Carmelo López Del Rincón, por su apoyo y guía en todos los trámites que conlleva la presentación de una Tesis.

También, agradezco a todos los compañeros y estudiantes que han pasado por el laboratorio. Todos de alguna manera u otra, formaran parte del recuerdo de la bonita etapa que fue el IBMCP en mi vida. En especial, a Eszter por nuestras conversaciones relajantes en la escalera de incendios cuando teníamos un mal día, a Mari Carmen por su sencillez y humildad, a Beltrán por sus ganas de aprender y de seguir proyectos que me ilusionaron mucho y a Guillermo porque con tu ironía siempre conseguías que nos riéramos un rato.

Una mención especial para mi equipo copa, sin ellas mis años en el IBMCP no hubieran sido tan especiales, ahora desde lejos añoro mucho esas escaleras y ese cubo amarillo, y mucha culpa la tienen ellas. A Vero porque aunque al principio me enseñó todo lo que sabía con mano dura, con el paso del tiempo se convirtió en una parte muy importante de mi vida, controlé su mal genio y pasamos a ser uña y carne. Ir a trabajar era menos duro cuando pensaba que ella estaría allí para compartir juntas todo lo que me pasaba tanto en casa como en el trabajo. A Myri porque conocerte fue toda una sorpresa, de ti aprendí mucho y tu carácter risueño alegro muchos de mis peores días. A mi Piki, porque nuestros humores congeniaron, y aunque siempre nos metíamos la una con la otra algo nos conectó y vivimos momentos únicos. Es un regalo poder seguir contando con vosotras.

Pero durante una tesis también se necesita el apoyo de las personas que nos quieren, y que sin ellas no creceríamos ni a nivel personal ni profesional. Gracias a mi familia, a mis padres y a mi hermano, que siempre están ahí. Con todas mis idas y venidas, siempre sin cuestionarse nada me han dado todo, saber que están ahí es la paz necesaria para afrontar cada día. Gracias a mis amigas por ocupar mi mente saturada los días que no se debía pensar. Y, sobre todo, a Mario por su apoyo y su amor. Él encontró la oferta JAE TEC que me llevó al 1.05 del IBMCP en Octubre del 2011. Sin él este trabajo nunca se habría escrito y, por eso, este trabajo es también el suyo. A todos, muchas gracias. 
ANEXOS 



\section{Solicitud para la presentación de la tesis por compendio de artículos}

Fecha: 2 de marzo de 2021

Nombre: María Teresa Cordero Cucart

Título de tesis: Aplicaciones del factor de transcripción Rosea1 de la ruta de las antocianinas como marcador visual en virología molecular y biotecnología de plantas.

\section{Relación de publicaciones}

(Referencia completa incluyendo autores, título, revista o editorial, D.O.I. y factor de impacto e indicadores de calidad de la publicación).

- Cordero, T., Cerdán, L., Carbonell, A., Katsarou, K., Kalantidis, K. and Daròs, J.A. (2017). Dicerlike 4 is involved in restricting the systemic movement of Zucchini yellow mosaic virus in Nicotiana benthamiana. Mol. Plant-Microbe Interact.; 30(1):63-71. doi: 10.1094/MPMI-11-160239-R. Q1. Factor de impacto: 3.69.

- Cordero, T., Mohamed, M.A., López-Moya, J.J., Daròs, J.A. (2017). A Recombinant Potato virus Y Infectious Clone Tagged with the Rosea1 Visual Marker (PVY-Ros1) Facilitates the Analysis of Viral Infectivity and Allows the Production of Large Amounts of Anthocyanins in Plants. Front. Microbiol.; 8:611. doi: 10.3389/fmicb.2017.00611. Q1. Factor de impacto: 4.23.

- Cordero, T., Rosado, A., Majer, E., Jaramillo. A., Rodrigo, G. and Daròs, J. (2018). Boolean Computation in Plants Using Post-translational Genetic Control and a Visual Output Signal. ACS Synth. Biol.; 7(10):2322-2330. doi: 10.1021/acssynbio.8b00214. Q1. Factor de impacto: 4.41 .

\section{Firma del solicitante}

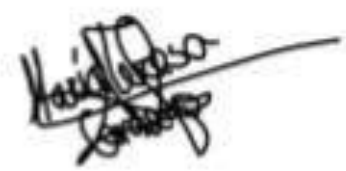

\section{VoBo Director(es)}

JOSE 


\section{voвo CAPD RAFAEL| Firmado digitalmente SIRERA| PEREZ \\ PEREZ 11:21:24+02'00'}

Anexo: documento de aceptación de los coautores 
ESCOLA DE DOCTORAT

\section{Autorización de co-autores no doctores para la inclusión de artículos en una Tesis Doctoral por compendio de artículos.}

La tesis doctoral desarrollada por Teresa Cordero Cucart, con título 'Aplicaciones del factor de transcripción Rosea1 de la ruta de las antocianinas como marcador visual en virología molecular y biotecnología de plantas', se presenta por compendio de artículos.

El doctorando declara que todos los co-autores de los artículos son doctores

(en caso de completar esta opción no es necesario completar las siguientes listas)

El doctorando declara que los siguientes co-autores de los artículos incluidos son doctores:

\begin{tabular}{|l|}
\hline Nombre y Apellidos \\
\hline Alberto Carbonell Olivares \\
\hline Konstantina Katsarou \\
\hline Kriton Kalantidis \\
\hline Mohamed A Mohamed \\
\hline Juan José López Moya \\
\hline Eszter Majer \\
\hline Alfonso Jaramillo Rosales \\
\hline Guillermo Rodrigo Tárrega \\
\hline Lidia Cerdán García \\
\hline José Antonio Daròs Arnau \\
\hline
\end{tabular}

Añadir tantas líneas como sea necesario

El doctorando declara que los siguientes co-autores de los artículos incluidos no son doctores:

\begin{tabular}{|l|l|}
\hline Nombre y Apellidos & Universidad en la que desarrolla su tesis \\
\hline Arantxa Rosado Pérez & No desarrolla tesis \\
\hline
\end{tabular}

Añadir tantas líneas como sea necesario

En cumplimiento de la Normativa de los Estudios de Doctorado en la Universitat Politècnica de València, se anexan las autorizaciones correspondientes de los coautores relacionados en la anterior tabla para la inclusión de los artículos en los que participan en la mencionada tesis 


\section{ESCOLA DE DOCTORAT}

doctoral, expresando, además, su renuncia a presentar el mismo artículo como parte de otra tesis.

En Valencia, a 2 de marzo de 2021

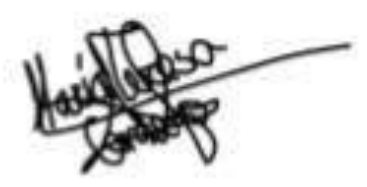

Firmado: Teresa Cordero Cucart 


\section{ESCOLA DE DOCTORAT}

La tesis doctoral desarrollada por Teresa Cordero Cucart, con título 'Aplicaciones del factor de transcripción Rosea1 de la ruta de las antocianinas como marcador visual en virología molecular y biotecnología de plantas', se presenta por compendio de artículos.

Da: Arantxa Rosado Pérez ${ }_{L}$ figura como co-autor de la publicación que se relacionan a continuación:

- Cordero, T., Rosado, A., Majer, E., Jaramillo. A., Rodrigo, G. and Daròs, J. (2018). Boolean Computation in Plants Using Post-translational Genetic Control and a Visual Output Signal. ACS Synth. Biol.; 7(10):2322-2330. doi: 10.1021/acssynbio.8b00214.

Y declara su aceptación para que el doctorando presente el trabajo como parte de su tesis doctoral, a la vez que expresa su renuncia a presentar el mismo como parte de otra tesis doctoral

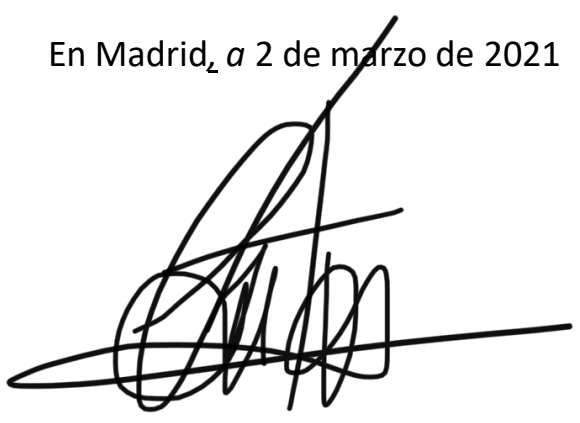

Firmado: Arantxa Rosado Pérez 
Los virus de plantas poseen la capacidad de parasitar células vegetales y poner a su disposición la maquinaria celular de la planta para la síntesis de sus propias proteínas. Aprovechando esta capacidad, la ingeniería genética ha conseguido la modificación del genoma de los potyvirus para utilizarlos como vectores de expresión de proteínas de interés humano en plantas. Su genoma está formado por un RNA de cadena sencilla que codifica, principalmente, una poliproteina que se procesa para dar aproximadamente 10 proteínas maduras. La inserción de un cDNA correspondiente al factor de transcripción Rosea 1 de la ruta de las antocianinas entre los cistrones NIb y CP del genoma viral. resulta en la biosintesis de estos compuestos en las células vegetales infectadas. Las antocianinas son compuestos flavonoides coloreados que se pueden observar a simple vista, por lo que la expresión de Roseal en el contexto de la infección viral es una herramienta biotecnológica muy útil para seguir la infección de virus de plantas. En esta Tesis se han investigado diferentes aplicaciones biotecnológicas basadas en la expresión del factor de transcripción Rosea 1 y la consecuente acumulación de antocianinas en el contexto de la biología de los potyvirus. 